\begin{abstract}
UNIVERSIDADE DE SÃO PAULO
ESCOLA DE COMUNICAÇÕES E ARTES

PROGRAMA DE PÓS-GRADUAÇÃO EM CIÊNCIAS DA COMUNICAÇÃO
\end{abstract}

JOSÉ REINALDO CASTRO MARTINS

\author{
PASSADO E MODERNIDADE \\ NO MARANHÃO PELAS \\ LENTES DE GAUDÊNCIO CUNHA
}


JOSÉ REINALDO CASTRO MARTINS

\section{PASSADO E MODERNIDADE NO MARANHÃO PELAS LENTES DE GAUDÊNCIO CUNHA}

Dissertação apresentada ao Programa de Pós-graduação em Ciências da Comunicação da Escola de Comunicações e Artes da Universidade de São Paulo como exigência para obtenção do título de Mestre em Ciências da Comunicação.

Orientador: Professor Doutor Boris Kossoy (ECA-USP).

São Paulo 
Catalogação da publicação

MARTINS, José Reinaldo Castro

Passado e modernidade no Maranhão pelas lentes

de Gaudêncio Cunha - São Paulo, 2008\ José Reinaldo Castro Martins - São Paulo: J. R. C. Martins, 2008.

197 p. : il.

Dissertação (Mestrado em Ciências da Comunicação) Universidade de São Paulo - USP, 2008).

Orientador: KOSSOY, Boris.

Bibliografia

1. Fotografia 2. História 3. História da fotografia 4. Jornalismo 5. Arquitetura. 


\section{PASSADO E MODERNIDADE NO MARANHÃO PELAS LENTES DE GAUDÊNCIO CUNHA}

Dissertação apresentada ao Programa de Pós-graduação em Ciências da Comunicação da Escola de Comunicações e Artes da Universidade de São Paulo como exigência para obtenção do título de Mestre em Ciências da Comunicação.

Orientador: Professor Doutor Boris Kossoy (ECA-USP).

Aprovada em

\section{COMISSÃO EXAMINADORA}
Professor Dr. Boris Kossoy - Orientador Universidade de São Paulo

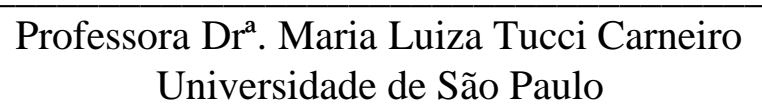

Professor Dr ${ }^{\mathrm{a}}$. Alice Mitika Koshiyama

Universidade de São Paulo 
Cada tempo 'novo' deu lugar a um discurso que considera 'morto' aquilo que o precedeu, recebendo um 'passado' já marcado pelas rupturas anteriores (CERTEAU, 2002). 


\section{AGRADECIMENTOS}

Aos meus pais José de Jesus Mendes Martins e Maria de Castro Martins (em memória).

A Boris Kossoy, pelo inventivo e orientação em todas as etapas do trabalho.

A Maria Luiza Tucci Carneiro pelas intervenções e pelo carinho com que acompanhou o trabalho e a Alice Mitika Koshiyama pelas observações e leituras pontuais na etapa de qualificação.

Aos meus irmãos, sobrinhos, cunhados e aos amigos em São Luís, São Paulo, Belém, Recife, Rio de Janeiro, New York (EUA), Salvador e Brasília pelo apoio intelectual, emocional e logístico.

Aos meninos Caetano Santos e Vitor Smith.

Às professoras da ECA-USP, Cremilda Medina e Dulcilia Buitoni.

Aos dirigentes (de 2005 a 2007), funcionários e pesquisadores ligados a setores e instituições educativas e culturais sediadas em São Luís que colaboraram de maneira substancial, liberando documentos para consultas e reprodução, concedendo depoimentos, sugestões, idéias e colaborando na árdua tarefa de localizar e identificar o material teórico e empírico.

À Secretaria de Cultura do Maranhão: Museu Histórico e Artístico, Museu de Artes Visuais, Biblioteca Pública Benedito Leite, Arquivo Público, Centro de Cultura Popular Domingos Vieira Filho e Departamento do Patrimônio Histórico do Maranhão.

Faço referência especial ao escritor Luiz Melo e demais pesquisadores e bibliotecários que trabalham ou transitam com regularidade pela Biblioteca Pública Benedito Leite e cooperaram comigo com idéias, na normalização e localização do material empírico.

Aos diretores do Estaleiro Escola do Sítio Tamancão, Curadoria de Bens Culturais do Palácio dos Leões, Superintendência do IPHAN no Maranhão, Departamento do Patrimônio Histórico da Prefeitura de São Luís, Associação dos Amigos dos Museus do Estado do Maranhão e administração do Cemitério do Gavião. 
Aos colecionadores particulares de fotografias e aos fotógrafos com mais de 60 anos citados no decorrer do trabalho.

Aos fotógrafos Airton Baren, Chico Otoni, Edgar Rocha e Márcio Vasconcelos pelas reproduções fotográficas e observações realizadas durante a pesquisa de campo.

Aos seguintes professores da UFMA: Manoel Barros Martins, Glória Corrêa e Regina Faria (Departamento de História), Flavio Reis (Sociologia e Antropologia), Ester Marques, Francisco Gonçalves, Joanita Mota e Sílvio Rogério de Castro (Comunicação Social) e a César Castro (Biblioteconomia e diretor do Centro de Ciências Sociais).

Aos seguintes professores da UEMA: Paulo Rios (História), Grete Pflueger e Taís Zenkner (Arquitetura).

Ao professor de Filosofia do UNICEUMA, Ribamar Lima.

Ao professor de filosofia José Ribamar Nascimento. (São Paulo)

Aos cineastas, em São Paulo, Beto Matuck, Eduardo Paranhos e Joel Yamaji.

À USP e ao CNPq pelo apoio. 


\section{RESUMO}

Passado e modernidade no Maranhão pelas lentes de Gaudêncio Cunha interpreta as fotografias que formam o Album do Maranhão em 1908, documento encomendado ao fotógrafo Gaudêncio Cunha pelo Governo do Maranhão para representar o Estado na Exposição Nacional realizada no Rio de Janeiro em 1908. O interesse dessa pesquisa é saber que finalidades conduziram Cunha na elaboração do Álbum e quais foram os critérios utilizados por ele na seleção das imagens. No álbum, elementos da modernidade vigentes no Maranhão da Primeira República são situados dentro de um cenário urbano que remonta ao final do século XVIII e início do século XIX. Gaudêncio Cunha ajustou o que era considerado moderno na passagem do século XIX para o século XX à soberba paisagem urbana de São Luís remanescente do Império e da Colônia. Essa composição de aparência harmônica, ele envolveu em um ambiente de mata exuberante. Seu intuito assemelha-se ao desejo de apresentar uma civilidade de perfil europeu, erguida em um ambiente tropical, muito próximo da imagem de Brasil criada no tempo do Império de Dom Pedro II, no século XIX. Interessava a Gaudêncio Cunha e seu cliente amenizar algumas imagens do passado, sendo as ruas estreitas de São Luís uma das mais incômodas. No que se considerava moderno dentro da nascente República Brasileira estava o estilo urbanístico que privilegiava largas avenidas com bulevares, no estilo francês, que contrastava com as ruas estreitas da capital maranhense. A pesquisa contextualiza o álbum de 1908 e seu autor na história da fotografia. Apresenta um levantamento sobre os fotógrafos que trabalharam no Maranhão entre 1846 até o início do século XX, com destaque para a história de vida de Gaudêncio Cunha e a participação maranhense na Exposição do Rio de Janeiro. Na última etapa, é feita uma interpretação de fotografias constitutivas do álbum de 1908, com base, sobretudo, na metodologia criada pelo historiador Boris Kossoy e na contribuição teórico-metodológica de Jacques Le Goff e de outros historiadores, a maioria vinculada às várias fases da Escola dos Annales.

Palavras-chave: fotografia, Gaudêncio Cunha, história, cultura, Maranhão. 


\begin{abstract}
"Passado e Modernidade no Maranhão pelas lentes de Gaudêncio Cunha" interprets the photographies that make the "Album do Maranhão in 1908" a document that was requested by the Government of Maranhão to the photographer Gaudêncio Cunha in order to represent the State in a National Exhibition held in Rio de Janeiro in 1908. The interest of this research is to know what led Cunha to make the album and his criteria to select the images. In the album the existing modernity elements of the First Republic in the State of Maranhão are placed within an urban scenario that dates back to the end of the XVIIIth century and beginning of the XIXth century. Gaudêncio Cunha focused what was considered to be modern in the changing of the XIXth to the XXth century - the superb urban landscape remaining from the Empire and from the Colony. Gaudêncio involved this composition that seemed to be harmonious in an environment of exuberant wood. His intention was like the desire of presenting a European profile civility that was built in a tropical environment, closer to the image of Brazil built at the times of the D.Pedro II's Empire in the XIXth century. It was of Gaudêncio and his client's interest to soften some past images. The narrow streets of São Luís were one of the points of concern in that matter. The urbanistic French style that privileged large avenues with boulevards contrasting with the narrow streets of the Maranhense capital was one of the things considered to be modern within the growing Brazilian Republic. This research gives context to the 1908's album and to its author in the photography history. It also gives a glance over the photographers that worked in Maranhão between 1846 and the beginning of the XXth century, highlighting Gaudêncio Cunha's history of life and the maranhense participation at the Rio de Janeiro's Exhibition. Last but not least, we interpret the photos in the 1908's album based on Boris Kossoy's methodology and on the Jacques Le Goff's theoretical-methodological contribution as well as of other historians - most of them linked to the various steps of the Annales School.
\end{abstract}

Key words: photography, Gaudêncio Cunha, history, culture, Maranhão. 


\section{LISTA DAS FOTOGRAFIAS}

Nesta lista, o que é denominado fotografia são, exclusivamente, as produções fotográficas elaboradas por Gaudêncio Cunha, através de seu ateliê, a Photographia União. É chamada de ilustração, a reprodução de detalhes dessas fotografias, da capa e de acabamentos do Album do Maranhão em 1908 e a da litogravura do século XIX de autoria de Miguel Cauto.

\section{INTRODUÇÃO}

Fotografia $1 \quad$ Vapor da Companhia Fluvial no Rio Mearim.

Fotografia 2 Embarcação Ipiranga.

\section{CAPÍTULO I}

Fotografia $3 \quad$ Escola Normal.

Fotografia 4 Rua Affonso Pena.

Fotografia 5 Rua do Sol.

\section{CAPÍTULO II}

Fotografia $6 \quad$ Menina Celeste.

Fotografia $7 \quad$ Casal.

Fotografia 8 Gerente do Comércio Francisco Aguiar, Manuel Martins de Campos.

Fotografia 9 Comerciante português, Ventura Francisco dos Santos.

Fotografia 10 Fachada da Photographia União, na Rua do Sol, 30 no início do século XX.

Fotografia 11 Ambiente interno da Photographia União no início do século XX. A Sala de Espera. 


\section{CAPíTUlO III}

Fotografia 12

Fotografia 13

Fotografia 14

Fotografia 15

Fotografia 16

Fotografia 17

Fotografia 18

Fotografia 19

Fotografia 20

Fotografia 21

Fotografia 22

Fotografia 23

Fotografia 24

Fotografia 25

Fotografia 26

Fotografia 27

Fotografia 28

Fotografia 29

Fotografia 30

Fotografia 31

Fotografia 32

Fotografia 33

Fotografia 34

Fotografia 35

Fotografia 36

Fotografia 37

Fotografia 38
Praça Odorico Mendes.

Praça Odorico Mendes.

Chafariz em um trecho da Avenida Silva Maranhão.

Fachada da Photographia União com beirais, no início do século XX.

Fachada do Telegrapho Nacional com platibandas e um imóvel vizinho com beirais.

Rua Portugal com pessoas em frente aos armazéns.

Rua Portugal com pessoas em frente aos armazéns.

Fábrica Cânhamo com pessoas na frente.

Mulheres trabalhadoras posam para o fotógrafo dentro de uma fábrica.

Rua do Egypto e igreja do Rosário.

Imóvel sede da Liga Marítima com trilhos em frente.

Igreja da Conceição com trilhos ao lado.

Palacete particular da Praça Gonçalves Dias com trilhos ao lado.

Hospital Portuguez com trilhos em frente.

Quartel do $5^{\circ}$ Batalhão de Infantaria na Praça Deodoro da Fonseca.

Praça João Lisboa com trilhos em primeiro plano.

Chafariz na Praça João Lisboa.

Rua do Passeio.

Povoação João Alves e um bonde puxado a burros.

Sítio Britania na estrada do Anil com um bondinho do tipo puxado a burros. Estação suburbana.

Estação da Companhia Ferro Carril.

Igreja de São João e trecho da Rua da Paz com dois modelos de postes.

Teatro São Luiz com suportes para fios de telefone ou de telégrafo no alto da fachada.

Fonte do Ribeirão.

Avenida Maranhense vista a partir do Palácio Episcopal em direção a rampa de acesso ao porto.

Avenida Maranhense vista a partir do trecho próximo ao acesso à rampa do porto, com o Palácio Episcopal ao fundo. 
Fotografia 39 Catedral da Sé, com a 'passagem' da Avenida Maranhense para a Praça Benedito Leite.

Fotografia $40 \quad$ Palácio do Governo. Entrada particular.

Fotografia 41 Palácio do Governo. Terraço de palestra.

Fotografia 42 Palácio do Governo. Sala de espera de visitas.

Fotografia 43 Palácio do Governo - $1^{\circ}$ Salão.

Fotografia 44 Palácio do Governo. Sala de conversa.

Fotografia 45 Sala do Superior Tribunal de Justiça do Maranhão.

Fotografia 46 Fachada do Palácio Episcopal ou Palácio do Bispo.

Fotografia 47 Fachada lateral do Palácio do Governo.

Fotografia $48 \quad$ Fachada da Intendência Municipal.

Fotografia 49 Praça Benedito Leite.

Fotografia $50 \quad$ Hotel Central.

Fotografia 51 Homens da Companhia de Bombeiros.

Fotografia 52 Prédio do Quartel da Companhia de Bombeiros, com os bombeiros e veículos.

Fotografia 53 Igreja dos Remédios.

Fotografia 54 Prédio do Liceu Maranhense.

Fotografia 55 Sala de Leitura da Biblioteca Pública.

Fotografia 56 Sala de aula de Chimica (Química) da Escola Normal.

Fotografia 57 Casas de taipa e palha na povoação Santa Ignez e os trilhos do Complexo Agroindustrial do Engenho Central, no Vale do Pindaré.

Fotografia $58 \quad$ Rua 28 de julho ou Rua do Giz.

Fotografia $59 \quad$ Estrada do Cutim.

Fotografia 60 Ponte da via férrea no Cutim

Fotografia 61 Porto de São Luís, com o mar em primeiro plano, e panorâmica da cidade. 


\title{
ILUSTRAÇÕES
}

\section{CAPÍTULO II}

\author{
Ilustração $1 \quad$ Verso da fotografia 8. \\ Ilustração 2 Pessoas nas sacadas da fachada do imóvel da Photographia União na Rua Sol, \\ 30. Detalhe da fotografia 10.
}

\section{CAPÍTULO III}

Ilustração 3

Capa do Album Maranhão em 1908.

Ilustração 4

Uma das páginas internas do Album do Maranhão em 1908 com pinturas de arranjos florais circundando as fotografias.

Ilustração 5 Pintura de arranjos florais no verso de uma das páginas internas do Album do Maranhão em 1908.

Ilustração 6

Detalhe de arranjos florais pintados em uma página interna do Album do Maranhão em 1908.

Ilustração 7 Retrato do governador Benedito Leite circundando por pinturas de arranjos florais.

Ilustração $8 \quad$ Nova fachada da Photographia União com platibandas.

Ilustração 9 Transeuntes em ruas carregando mercadoria. Detalhe da Fotografia 17.

Ilustração $10 \quad$ Jovens transeuntes descalços. Detalhe da Fotografia 18.

Ilustração 11 Pessoas na janela de Casa Comercial. Detalhe da Fotografia 18

Ilustração 12 Pessoas na porta da Fábrica Cânhamo. Algumas estão descalças. Detalhe da fotografia 19.

Ilustração 13 Página do Album do Maranhão em 1908 com fotografias da Companhia de Bombeiros.

Ilustração 14 Menina sentada em um dos veículos da Companhia de Bombeiros. Detalhe da Fotografia 52.

Ilustração 15 Panorâmica de São Luís com pescadores em primeiro plano, Tomada da Ponta do São Francisco pelo artista Miguel Cauto. 


\section{SUMÁRIO}

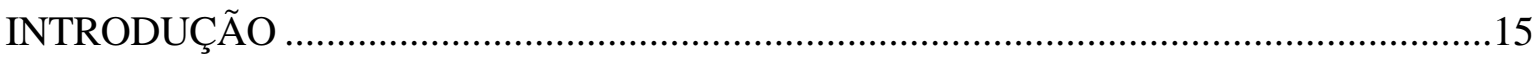

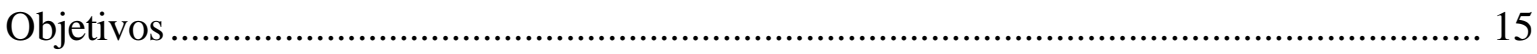

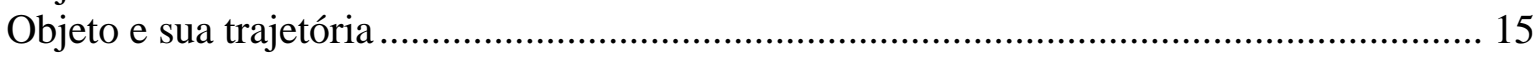

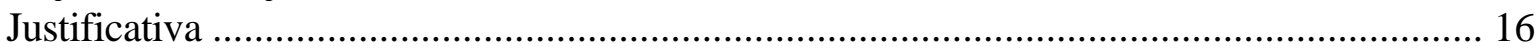

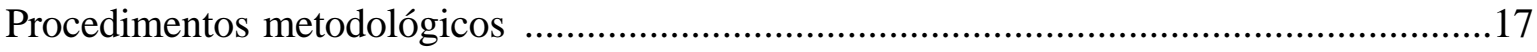

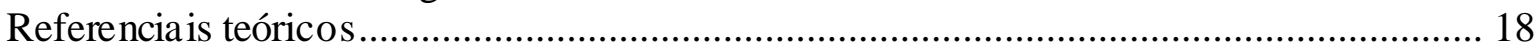

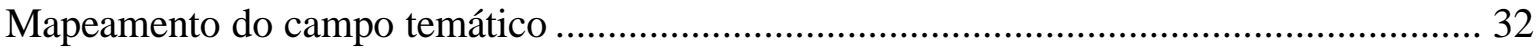

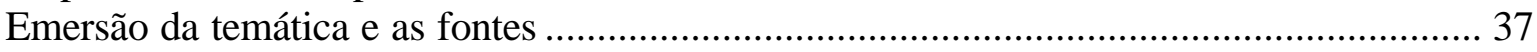

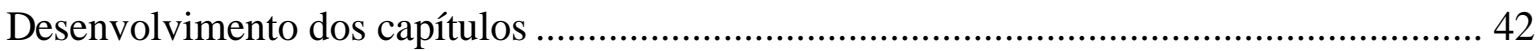

\section{CAPÍTULO I}

O ALBUM DO MARANHÃO EM 1908 E A HISTÓRIA DA FOTOGRAFIA ................. 43

$1.1 \mathrm{O}$ velho e o novo nas primeiras fotografias de paisagens maranhenses ........................ 43

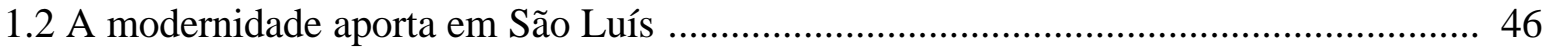

1.3 A Fotografia no século XIX e início do século XX .................................................. 50

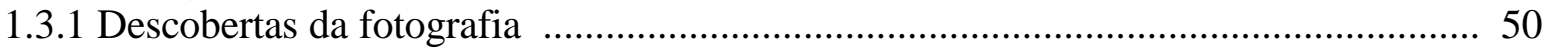

1.3.2 Daguerreótipo no Brasil ..................................................................................... 53

1.3.3 Fotógrafos anônimos e o retrato brasileiro ........................................................... 54

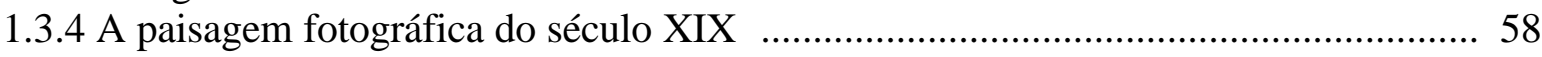

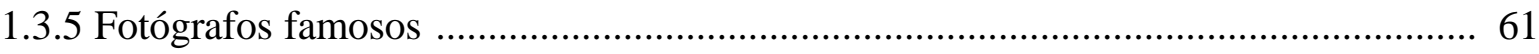

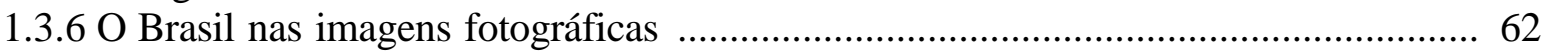

1.3.6.1 Mestiços e negros no álbum de 1908 e nas imagens etnográficas ........................... 63

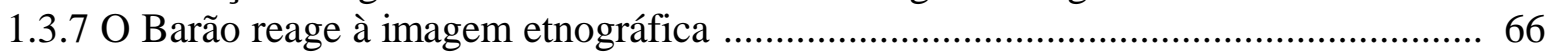

\section{CAPÍTULO II}

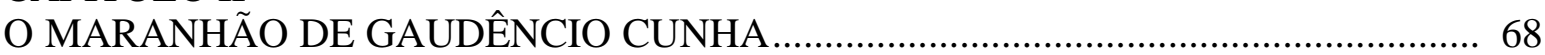

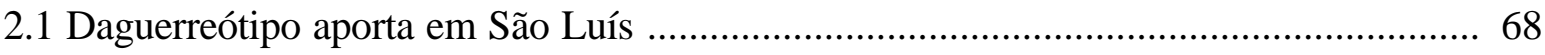

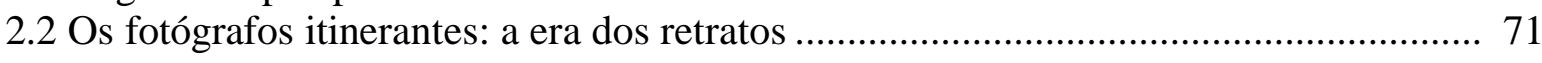

2.3 Primeiras fotografias de paisagens maranhenses.................................................. 74

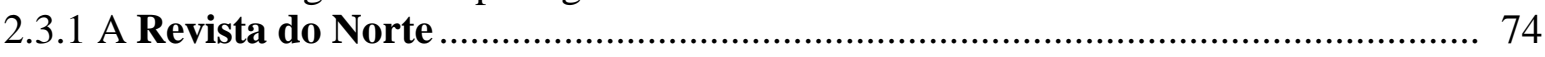

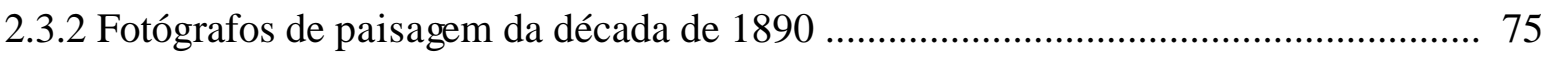

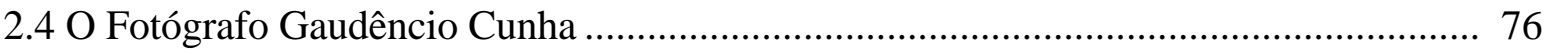

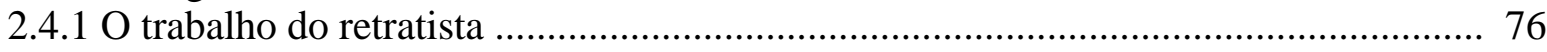

2.4.2 Viagens, prêmios, álbuns e exposições ...................................................................... 79

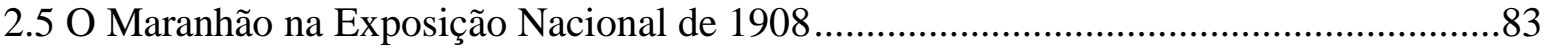

\section{CAPÍTULO III}

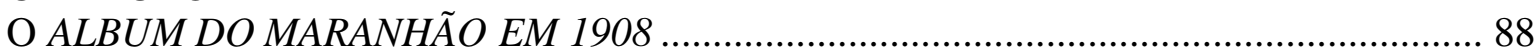

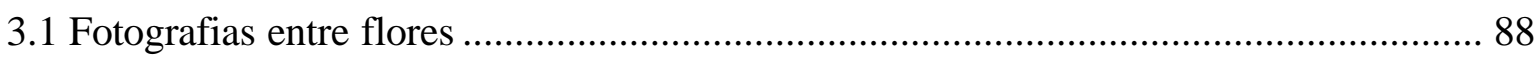

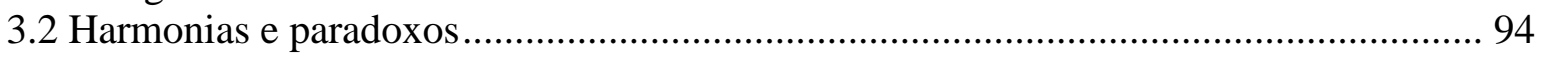

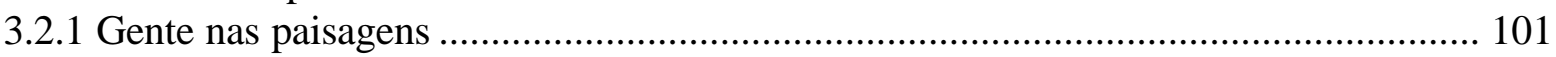

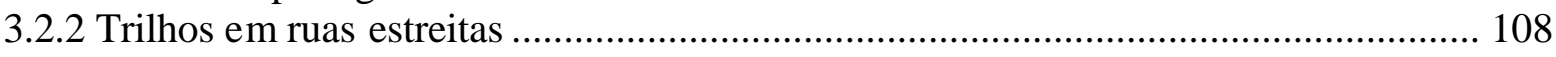




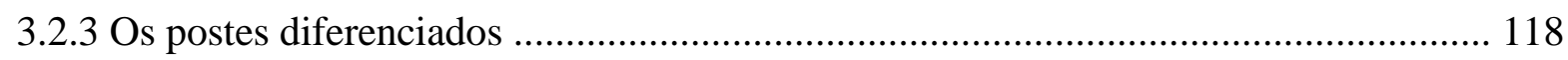

3.2.4 Avenida Maranhense ……………………………....................................... 121

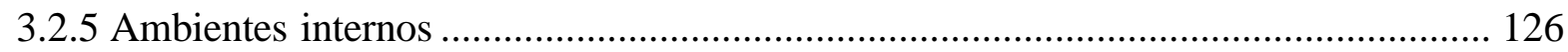

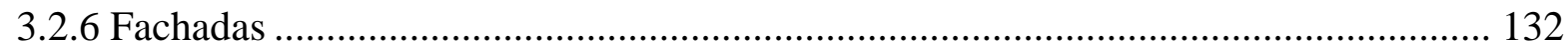

3.2.7 Praça Benedito Leite .......................................................................................... 134

3.2.8 Companhia de Bombeiros.................................................................................. 136

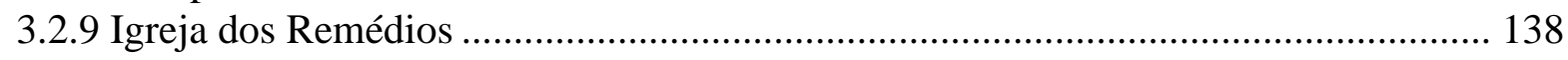

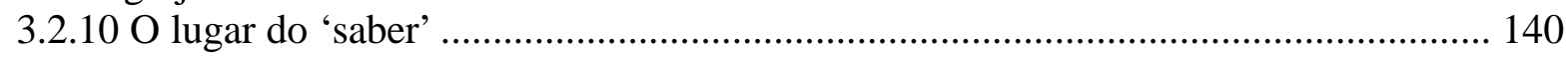

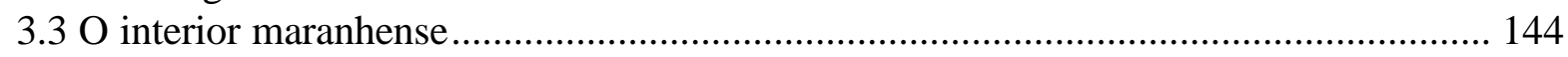

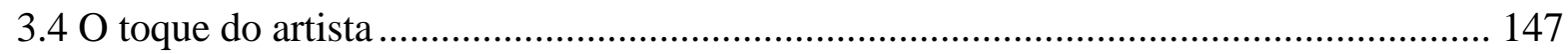

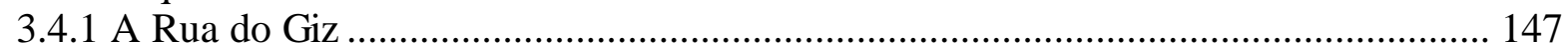

3.4.2 Influência da pintura na fotografia ......................................................................... 150

Considerações Finais ...………………………………………………………….... 157

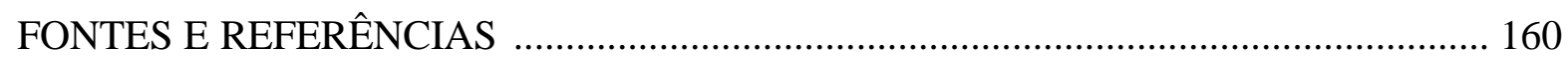




\section{INTRODUÇÃO}

\section{Objetivos}

A intenção da pesquisa "Passado e modernidade no Maranhão pelas lentes de Gaudêncio Cunha" é lançar um olhar interpretativo sobre o Album do Maranhão em 1908¹, que apresenta fotografias de paisagens ${ }^{2}$ maranhenses do final do século XIX e início do século XX. Para alcançar esse objetivo, é necessário depreender a temporalidade, cultura e sociedade em que a obra foi construída e representada. Em seguida, é preciso buscar a história de vida do autor para, por fim, identificar e interpretar os conteúdos das fotografias reunidas no álbum. Nessa última etapa, serão verificadas quais as finalidades que influenciaram o fotógrafo a selecionar imagens de São Luís e seus arredores e de localidades no interior e no litoral maranhense.

\section{Objeto e sua trajetória}

O objeto em estudo é o Album do Maranhão em 1908 elaborado pelo fotógrafo Gaudêncio Cunha, em seu ateliê, a Photographia União, que funcionou em São Luís na passagem do século XIX para XX. Foi produzido um único exemplar que se encontra no Museu Histórico e Artístico do Maranhão, o MHAM ${ }^{3}$. Reúne 211 fotografias originais, sendo 210 de vistas maranhenses e um retrato ${ }^{4}$ do governador Benedito Leite (1857-1909), centralizado em uma das páginas introdutórias. Apesar de ser de um tempo em que técnicas de reprodução fotomecânica já eram correntes no Brasil ${ }^{5}$, é um artefato artesanal, ou seja: não foi impresso.

O álbum é uma encomenda solicitada pelo Governo do Maranhão, na gestão de Benedito Leite. Foi um dos objetos do Maranhão enviados para a Exposição Nacional de

\footnotetext{
${ }^{1}$ O nome do álbum é Album do Maranhão em 1908, com a palavra Album, sem a acentuação utilizada nos dias de hoje. Nesse trabalho será utilizado esse nome original, grafado sempre em itálico, ou termos como: álbum e álbum de 1908.

${ }^{2}$ Os termos paisagem e vista serão utilizados nessa pesquisa como categorias para identificar as fotografias de áreas rurais (incluindo as da natureza) e de cenas urbanas como ruas, praças e fachadas de edificações. As fotografias de áreas internas dos imóveis serão chamadas de ambientes internos ou fotografias de ambientes internos.

${ }^{3}$ O Museu Histórico e Artístico do Maranhão - MHAN está localizado na Rua do Sol, 302, Centro. CEP: 65020. São LuísMA - Brasil. Fone: (098) 32189920

${ }^{4} \mathrm{O}$ termo retrato significa, nesta pesquisa, a fotografia centralizada em uma pessoa, ou grupo de pessoas; imagem criada em estúdio ou em estruturas próprias de um estúdio da época, em que o fotógrafo tinha condições de melhor controlar a iluminação adequada e as poses dos clientes. Os retratados compõem toda a fotografia ou compartilham o espaço com cenários. Mas, eles sempre estão em primeiro plano, dominando o espaço.

${ }^{5}$ KOSSOY, Boris. Dicionário histórico-fotográfico brasileiro: fotógrafos e ofício da fotografia no Brasil (1833-1910). São Paulo: Instituto Moreira Salles, 2002, p.16.
} 
1908, realizada no Rio de Janeiro em comemoração aos 100 da Abertura dos Portos Brasileiros às Nações Amigas pelo rei Dom João VI, em 1808.

A concepção e a composição do álbum são ao mesmo tempo suntuosas e delicadas. O cuidado na elaboração é percebido em detalhes como a seleção e disposição das fotografias. Desenhos florais, retocados à mão, emolduram as imagens que estão distribuídas em 100 páginas. A prioridade são as fotografias, pois as informações escritas só aparecem em forma de pequenas legendas e nas titulações iniciais.

Desde o dia 3 de setembro de 1973 o álbum de 1908 está sob custódia do Museu Histórico e Artístico do Maranhão. Integrava, anteriormente, o acervo da Biblioteca Pública Benedito Leite (São Luís), onde não há regis tros oficiais ou indicativos de sua procedência. Segundo o escritor e historiador Jomar Morais ${ }^{6}$, era parte do acervo de jornais, manuscritos e mapas que pertenceram ao historiador José Ribeiro do Amaral (1853-1927). No museu, a paginação foi decomposta para efeitos de melhor arquivamento.

Do total de 215 imagens produzidas por Gaudêncio Cunha no Maranhão e localizadas na fase de levantamento de dados, 61 integram a lista de fotografias incluída nessa pesquisa. Quatro são retratos e não fazem parte do álbum de 1908. As outras 56 são do álbum, sendo que a fachada a Photographia União é apresentada duas vezes.

Foram selecionadas do álbum as fotografias que melhor traduziram em seu conteúdo, as relações sociais e culturais que influenciaram no processo de composição do álbum como um todo. Considerando esse aspecto, a prioridade incidiu sobre imagens de paisagens urbanas de São Luís.

O critério de seleção considerou, substancialmente, fotografias que uniram cenários remanescentes dos tempos do Império e da Colônia e símbolos considerados modernos na jovem república do tempo em que Gaudêncio Cunha viveu no Maranhão. Esse aspecto, de aparência harmônica, é o tema central da pesquisa.

\section{Justificativa}

A pesquisa é uma forma de divulgar e ampliar as potencialidades de uso das fotografias que formam o álbum de 1908 como fontes de pesquisa científica. Estudiosos de vários ramos do saber, entre os quais, historiadores, antropólogos, arquitetos e sociólogos, poderão utilizar o trabalho aqui proposto como referência. Apresenta-se importante,

\footnotetext{
${ }^{6}$ SARDINHA, Maria da graça. Álbum do Maranhão em 1908 - Gaudêncio Cunha. Rio de janeiro, Spala, 1987, p. 17.
} 
principalmente, para cientistas que trabalham com a história cultural em suas várias abordagens temáticas, entre as quais, educação, arquitetura e vida privada.

Uma vez decodificadas, as imagens podem ser melhor utilizadas como referência nos serviços de restauração e preservação do conjunto arquitetônico e paisagístico de São Luís ${ }^{7}$. A pesquisa aspira a uma maior inserção das fotografias que formam o álbum dentro desse processo, já que o centro histórico de São Luís é de inestimável valor para o Brasil e para o mundo. Vale ressaltar que a capital maranhense guarda o maior conjunto arquitetônico de origem portuguesa localizado no Continente Americano.

O intento, também, é de transformar o trabalho em instrumento referencial de fomento e valorização da fotografia, sobretudo as do álbum de 1908, como instrumento pedagógico dentro das escolas do ensino fundamental, médio e universidades.

\section{Procedimentos metodológicos}

A pesquisa seguiu a metodologia de Boris Kossoy elaborada para se estudar a história da fotografia. A primeira etapa, denominada de análise técnico-iconográfica ${ }^{8}$, consistiu no levantamento das informações bibliográficas e das fontes, centrando a atenção principalmente na localização dos elementos constitutivos das fotografias e suas coordenadas de situação, que são o espaço e o tempo em que o objeto pesquisado foi elaborado.

Nessa fase, foi feita a identificação dos elementos icônicos que compõe o conteúdo da representação. Assim foi possível reunir o material empírico e referencial para um segundo momento metodológico, que é o de interpretação do conteúdo fotográfico.

$\mathrm{Na}$ análise técnico-iconográfica, são considerados fontes históricas informações escritas, iconográficas, orais e objetos remanescentes da época em estudo. A sistematização dos dados seguiu o seguinte roteiro: procedência, conservação e identificação do documento, informações referentes aos assuntos (temas representados nas imagens fotográficas) e subsídios referentes de Gaudêncio Cunha e outros atores envolvidos.

A análise técnico-iconográfica incidiu sobre a etapa posterior, chamada de interpretação iconológica, na qual a aproximação sobre o ocorrido e o construído pelo

\footnotetext{
${ }^{7}$ Fotografias de paisagens urbanas de São Luís que integram o álbum de 1908 já foram usadas como referência para restauração do centro histórico de São Luís, o que contribuiu para que a UNESCO tombasse esse sítio históricoarquitetônico como Patrimônio Cultural da Humanidade. Ver: ANDRÈS, Luiz; MOREIRA, Rafael; SILVA, Ronald A. Centro histórico de São Luís - Maranhão - Brasil. Patrimônio Mundial. São Paulo: Audichromo/UNESCO/SECMA, 1998.

${ }^{8}$ KOSSOY, Boris. Fotografia e história. São Paulo: Ateliê Editorial, 2003, p.73-96.
} 
fotógrafo foi evidenciado no diálogo com as pistas referentes às imagens formadoras do album e referência bibliográfica.

A metodologia adotada encontra-se associada aos fundamentos da história cultural, em especial o que estabelece a necessidade de uma investigação de caráter interdisciplinar e transdisciplinar, como expressa Kossoy ${ }^{9}$.

Kossoy estabelece uma separação entre história da fotografia e o uso da fotografia como documento investigativo nos diversos ramos do conhecimento. Esse segundo aspecto, o autor chama de história através da fotografia.

A separação entre história do registro do tema e histórias dos temas registrados na fotografia, na sua interpretação, tem apenas efeitos de caráter didático e não impede uma "[...] retroalimentação contínua de informação [...]"10. Por isso mesmo, nessa pesquisa essas duas vertentes são indissociáveis. Assim, alguns trabalhos de cientistas que atuaram dentro da história através da fotografia serão citados, pois as pesquisas deles interessam à história da fotografia que está sendo investigada.

\section{Referenciais teóricos}

A base teórica, desde a fase de análise técnico-iconográfica, centrou-se em duas vertentes básicas: a história da fotografia, sobretudo a interpretada por Boris Kossoy e a contribuição teórico-metodológica no campo historiográfico e da história elaborada em várias fases da Escola dos Annales, em especial os estudos de Jacques Le Goff.

Para Boris Kossoy, a fotografia não é a imagem incontestável de uma realidade, mas uma criação do fotógrafo que seleciona e exclui conteúdos. $\mathrm{O}$ ato fotográfico envolve interesses diversos, incluindo sentimentos, desejos e anseios inerentes ao criador da imagem. Ao mesmo tempo em que é uma elaboração, a fotografia mantém rastros que indiciam o passado. "O vínculo com o real sustenta o status indicial da fotografia", explica ${ }^{11}$. E são esses rastos que interessam ao historiador.

Kossoy desmistifica a idéia de que a fotografia fala por si ou vale por mil palavras. Para ele, esse documento, aliado com outras fontes históricas, cria as condições para o historiador interpretar a trama que motivou o clique da máquina. Por trás do ato

\footnotetext{
${ }^{9}$ KOSSOY, Boris. Os tempos da fotografia: o efêmero e perpétuo. Cotia: Ateliê Editorial, 2007, p. 26-27 e 34.

${ }^{10}$ KOSSOY, Boris. Construção e desmontagem da Informação Fotográfica: teoria e história. In: Revista da USP, n. 61, Jun./ago., 2004b, p. 228.

${ }^{11}$ KOSSOY 2007, p.42.
} 
fotográfico, houve uma criação dentro de um tempo e espaço, cultura e grupo social. É esse acontecimento, anterior ao surgimento da fotografia, o autor chama de primeira realidade.

A fotografia, por sua vez, independente da trama que a formou, pode ser vista de diversas maneiras, dependendo de quem a olha. Logo depois que se separa da primeira realidade, de seu ato formador, começa a existir como "realidade da produção simbólica", como explica Cremilda Medina ${ }^{12}$. É a fotografia em si, como artefato. A partir desse momento, passa a dialogar com as emoções e referências culturais da pessoa ou grupo social que a vê. Esse diálogo entre o receptor e a fotografia, separado da primeira realidade, é o que Kossoy chama de segunda realidade.

A primeira realidade e segunda realidade são as duas formas de manifestação da fotografia e estarão presentes em toda a pesquisa. Como afirma Kossoy, "Destino perverso esse, o da fotografia que, num dado momento, registra a aparência dos fatos, das coisas, das histórias privadas e públicas, e que, no momento seguinte, e ao longo de sua trajetória documental, corre o risco de significar o que não foi em sua origem"13.

a) Primeira realidade

Inicialmente, cabe constatar o seguinte: se há uma seleção e constituição anterior e durante o ato fotográfico, então as fotografias do Album do Maranhão em 1908 resultam de uma criação. Mas qual a finalidade dessa seleção e construção? Kossoy, em suas reflexões, reafirma que "toda fotografia foi produzida com certa finalidade" ${ }^{14}$. O fotógrafo desejou ou foi incumbido de selecionar determinada personagem ou paisagem. E essas finalidades decorrem de uma trama precedente à existência da fotografia enquanto documento. A imagem fotográfica apenas retém traços desse momento que é a primeira realidade ${ }^{15}$.

A primeira realidade é o tempo da criação, o instante do clique da máquina. Nesse instante, efêmero, o fotógrafo seleciona e exclui conteúdos ou até mesmo 'arma' pura e simplesmente o que acha conveniente incluir na composição da imagem.

Peter Burke relata situações em que os fotógrafos fizeram mais do que estabelecer escolhas: “[...] ocasionalmente, os fotógrafos foram muito além de mera seleção. Antes da década de 1880, na era da câmara de tripé e exposições de 20 segundos, os

\footnotetext{
${ }^{12}$ KOSSOY, Boris. Os tempos da fotografia: o efêmero e o perpétuo. Cotia: Ateliê Editorial, 2007. p. 14.

${ }^{13}$ Ibid., p. 153.

${ }^{14}$ KOSSOY, Fotografia e história. 3. ed, São Paulo: Ateliê Editorial, 2003. p. 47-48, grifo nosso.

${ }^{15}$ KOSSOY, Boris. Os tempos da fotografia: o efêmero e o perpétuo. Cotia: Ateliê Editorial, 2007. p. 134.
} 
fotógrafos compunham cenas, dizendo às pessoas onde deviam se posicionar e como se comportar $[\ldots]^{\prime, 16}$.

Só que mesmo sendo produzida artificialmente, a fotografia carrega um rastro indicial que garante “[...] objetiva constatação da existência do assunto [...]"17 ${ }^{\text {. Barthes }}{ }^{18}$ percebeu essa particularidade. Ele vê a fotografia como uma fragmentação "[...] falsa no nível da percepção, verdadeira no nível do tempo [...]”. Para ele “[...] a fotografia não rememora o passado (não há nada de proustiano numa foto). $\mathrm{O}$ efeito que ela produz em mim não é o de restituir o que é abolido (pelo tempo, pela distância), mas o de atestar que o que vejo de fato existiu [...]"19 . Isso, mesmo sendo a fotografia uma criação.

Se a fotografia, por um lado, é uma criação do fotógrafo, por outro, Kossoy as vê como um meio de conhecimento $^{20}$ com características particulares ausentes em outros documentos. Por isso as considera uma fonte histórica preciosa para o conhecimento do passado, principalmente porque, apesar de ser uma criação, a fotografia apresenta um fato exatamente como aconteceu ${ }^{21}$.

Só que para a fotografia manifestar-se como fonte de pesquisa, é imprescindível, segundo ele, contextualizá-la no processo histórico, abrindo o diálogo com outras fontes documentais, incluindo as escritas e as orais ${ }^{22}$. Somente dessa maneira é possível interpretar a primeira realidade, ou as motivações que conduziram o recorte do fato simbolicamente perpetuado.

A contextualização histórica é de fundamental importância na visão do autor, pois desvenda as ligações culturais e sociais que proporcionaram a formação da fotografia. Através desse recurso, é possível interpretar o que ocorreu na gênesis, o que motivou a origem do simbólico, situando as imagens no tempo e no espaço em que foi criada ${ }^{23}$.

$\mathrm{Na}$ primeira realidade, circularam aparências, contradições, sentimentos e ausências, em meio às instituições sociais e à vida cultural. As fotografias são valorizadas como fonte por Kossoy justamente porque contêm rastros desse passado. Retêm pistas, ao mesmo tempo visíveis e complexas, da realidade em que o fotógrafo viveu: "Uma única imagem contém em si um inventário de informações acerca de um determinado momento passado; ela sintetiza no documento um fragmento do real visível, destacando-o do contínuo

\footnotetext{
${ }^{16}$ BURKE, Peter. Testemunha ocular: história e imagem. Bauru: Edusc, 2004, p. 28.

${ }^{17}$ KOSSOY, Boris. Realidades e ficções na trama fotográfica. São Paulo: Ateliê Editorial, 2000. p. 134.

${ }^{18}$ BARTHES, Roland. A câmara clara. Rio de Janeiro: Nova Fronteira, 1984. p. 169,123.

${ }^{19}$ Ibid., p. $169,123$.

${ }^{20}$ KOSSOY, Boris. Os tempos da fotografia: o efêmero e o perpétuo. Cotia: Ateliê Editorial, 2007. p. 32, 42, 54-55.

${ }^{21}$ Ibid., p. 31 .

${ }^{22}$ Ibid., p.51.

${ }^{23}$ KOSSOY, Realidades e ficções na trama fotográfica. São Paulo: Ateliê Editorial, 2000.
} 
da vida. Os espaços urbanos, os monumentos arquitetônicos, o vestuário, a pose e as aparências elaboradas dos personagens estão ali congelados [...]"24.

$\mathrm{A}(\mathrm{s})$, fotografia(s), isoladamente, pouco $\operatorname{diz}(\mathrm{em})$ sobre a trama que a(s) formou e sobre a realidade na qual essa trama encontra-se inserida. Jean Keim é um dos que adverte ser engano pensar que o estudo da imagem como processo de conhecimento poderá abdicar de outras fontes, em especial do signo escrito ${ }^{25}$.

Com relação ao álbum de 1908 , ao se buscar a primeira realidade ou o ato criador das fotografias, são abertos vários questionamentos. O Maranhão do início do século XX teve somente a forma apresentada por Gaudêncio Cunha? Evidente que não. O que há no álbum é um conjunto de belas paisagens recortadas e selecionadas pelo fotógrafo. Tanto que alguns historiadores falam de situações vividas nessa época que são invisíveis no álbum. Aconteceram surtos epidêmicos em São Luís ${ }^{26}$, as condições de trabalho nas fábricas maranhenses eram insipientes ${ }^{27}$ e os serviços públicos deficitários, como o de abastecimento de água que foi grave entre 1902 e o início da década de $1920^{28}$.

Então, por que Gaudêncio Cunha apresenta o Maranhão predominantemente asséptico? O que o motivou a selecionar imagens de paisagens que remetem a uma 'civilidade' de traços europeus? São esses questionamentos que interessam. A(s) ausência(s) pode $(m)$ ser motivo de investigação em outra pesquisa.

O propósito é apresentar o Album do Maranhão de 1908 não como um conjunto de imagens que omite a realidade de uma época, mas como o recorte representativo de realidades presentes e recorrentes no imaginário do final do século XIX e início do século $\mathrm{XX}$.

\footnotetext{
${ }^{24}$ KOSSOY, Boris. Fotografia e história. 3. ed, São Paulo: Ateliê Editorial, 2003. p. 101.

${ }^{25}$ Ibid., p. 78-79.

${ }^{26}$ ALMEIDA, Maria da C. P. Saúde pública e pobreza. São Luís na Primeira República In: COSTA, Wagner Cabral (org). História do Maranhão: novos estudos. São Luís: EDUFMA, 2004, p. 241.

${ }^{27}$ CORREIA, Maria da Glória G. Nos fios da trama: quem é essa mulher? Cotidiano e trabalho do operariado feminino em São Luís na virada do século XX. São Luís: Edufma, 2006.

${ }^{28}$ PALHANO, Raimundo. A produção da coisa pública. Serviços públicos e cidadania na Primeira República: a república ludovicense. São Luís: IPES/SIOGE, 1988, p. 199.
} 
b) Segunda realidade

Depois da primeira realidade, do efêmero momento de criação da fotografia, surge o simbólico. A partir desse instante, a imagem ganha independência do seu criador e entra na fase de recepção. Começam as relações fotografia/receptor dentro das confortáveis temporalidades e espaços posteriores ao ato fotográfico. Segundo Kossoy, o ato criador é efêmero e se dilui no instante em que é registrado. A memória, contudo, permanece pela fotografia $^{29}$.

A fotografia, na condição de representação simbólica, recebe significados distintos quando dialoga com a vivência de cada pessoa. Adquire uma "imobilidade plana e achatada", como observa Dubois ${ }^{30}$ e faz-se infinita pela interação com o observador. Essa locomoção que a fotografia realiza com os seus receptores depois de sua concepção é o que Kossoy chama de segunda realidade ${ }^{31}$. Ao contrário da primeira realidade, que é efêmera, na segunda realidade, o conteúdo se perpetua.

[...] A fotografia estabelece em nossa memória um arquivo visual de referência insubstituível para o conhecimento do mundo. Essas imagens, entretanto, uma vez assimiladas em nossas mentes, deixam de ser estáticas; tornam-se dinâmicas e fluidas e mesclam-se ao que somos, pensamos e fazemos. Nosso imaginário reage diante das imagens visuais de acordo com nossas concepções de vida, situações sócio-econômicas, ideologia, conceitos e pré-conceitos [... $]^{32}$.

Na segunda realidade, a fotografia, para o autor, perpetua-se, mas, parcialmente, pois a trajetória pode ser interrompida ${ }^{33}$. O objeto fotográfico corre risco de ser destruído, deletado de um arquivo virtual ou simplesmente perder o brilho e desaparecer com o tempo, como desconfiaram os moradores de São Luís quando olharam a fotografia pela primeira vez, em 1846. Eles pensaram que a fotografia desmerecesse $e^{34}$ com brevidade.

Depois de separada de seu momento de criação, a fotografia faz-se infinita pela interação com o espectador. Penetra nas memórias humanas, cruzando sentimentos, emoções, medos, expectativas. Adquire vários significados no momento em que o observador apropriase dela no seu tempo e espaço.

\footnotetext{
${ }^{29}$ KOSSOY, Boris. Os tempos da fotografia: o efêmero e o perpétuo. Cotia: Ateliê Editorial, 2007. p.42.

${ }^{30}$ DUBOIS, Philippe. O ato fotográfico. Campinas: Papirus, 2004. p. 97.

${ }^{31}$ A categoria é explicitada 2000, p. 45.nas obras do autor já citadas.

32 2000, p. 45.

${ }^{33}$ KOSSOY, Boris. Realidades e Ficções na trama fotográfica. São Paulo: Ateliê Editorial, 2000, p. 133.

${ }^{34}$ Publicador Maranhense 2 de setembro de 1846.
} 
Para Kossoy ${ }^{35}$, as imagens fotográficas têm uma natureza polissêmica, o que possibilita "sempre uma leitura plural, dependendo de quem as aprecia". Na relação da fotografia com o observador, acontece um diálogo da "imagem com a imagem" ${ }^{36}$. Ou seja: é estabelecido um elo entre a imagem fotográfica e as imagens mentais do receptor. E dentro desse diálogo fotografia/receptor podem ocorrer inúmeras interpretações.

Uma das interpretações ocorre, na visão de $\operatorname{Kossoy}^{37}$, quando "certos elementos se conectam" entre a memória do receptor e o conteúdo da imagem, remetendo a uma sensação que “[...] ultrapassa os conteúdos temáticos... Levando-nos a refletir sobre algo cuja presença pressentimos, mas que não está ali, fisicamente [...] ${ }^{, 38}$. O autor esclarece que essa idéia nada tem em comum com o punctum de Barthes ${ }^{39}$. Mas, relaciona-se às motivações que levaram Gaudêncio Cunha a fotografar a Rua 28 de julho, ou Rua do Giz (Fotografia 58), em São Luís, imagem incluída no álbum de 1908.

Dependendo da proximidade que o receptor tem com ato fotográfico, a imagem pode apresentar-se vulnerável a inúmeras interpretações. A relação fotografia/observador une-se ao tempo, lugar e contexto cultural em que o receptor se encontra. Os valores podem mudar dependendo das expectativas de cada um. Há, por exemplo, diferença entre uma imagem de álbum de família, de valor emocional e outra que desperte somente interesse científico a um historiador.

Como o Album do Maranhão em 1908 foi visto na Exposição Nacional de 1908, no Rio de Janeiro? Ao olhar as fotografias de paisagens maranhenses, o escritor maranhense Artur Azevedo, por exemplo, teve uma reação saudosista de sua terra natal ${ }^{40}$. E os que não conheciam o Maranhão? Qual a reação deles? Os transeuntes que aparecem distantes nas fotografias chamaram a atenção dos visitantes da exposição? Ou eles se identificaram somente com as edificações dominantes no conteúdo da maioria das imagens?

\footnotetext{
${ }^{35}$ KOSSOY, Boris. Realidades e Ficções na trama fotográfica. São Paulo: Ateliê Editorial, 2000. p. 44.

${ }^{36}$ KOSSOY, Boris. Os tempos da fotografia: o efêmero e o perpétuo. Cotia: Ateliê Editorial, 2007. p. 148-153.

${ }^{37}$ Ibid., p. 150.

${ }^{38}$ Ibid., p. 149.

${ }^{39}$ BARTHES, Roland. A câmara clara. Rio de Janeiro: Nova Fronteira, 1984.

${ }^{40}$ SILVA FILHO, José Oliveira da. Olhos de ver: a cidade entre a retórica do visual e do escrito. Monografia de especialização (Especialização em História do Maranhão) - CECEN/UEMA, São Luís, 2006, p. 34.
} 
O olhar atento de um antropólogo, nos dias de hoje, certamente estaria mais propenso a identificar as pessoas, pois os transeuntes ${ }^{41}$ 'estão lá', como afirma Barthes ${ }^{42}$, tal qual um punctum chamando a atenção de nossos olhos.

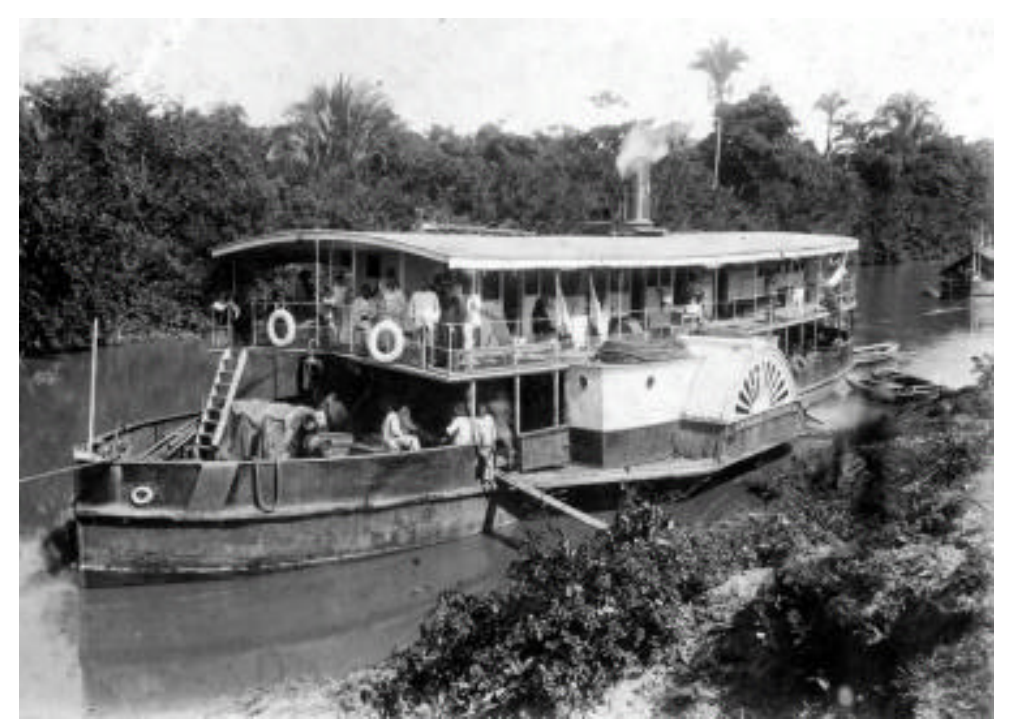

Fotografia 1 - Vapor da Companhia Fluvial no Rio Mearim. Album..., s.n.p., gelatina/prata, 15 x $20 \mathrm{~cm}$, MHAM.

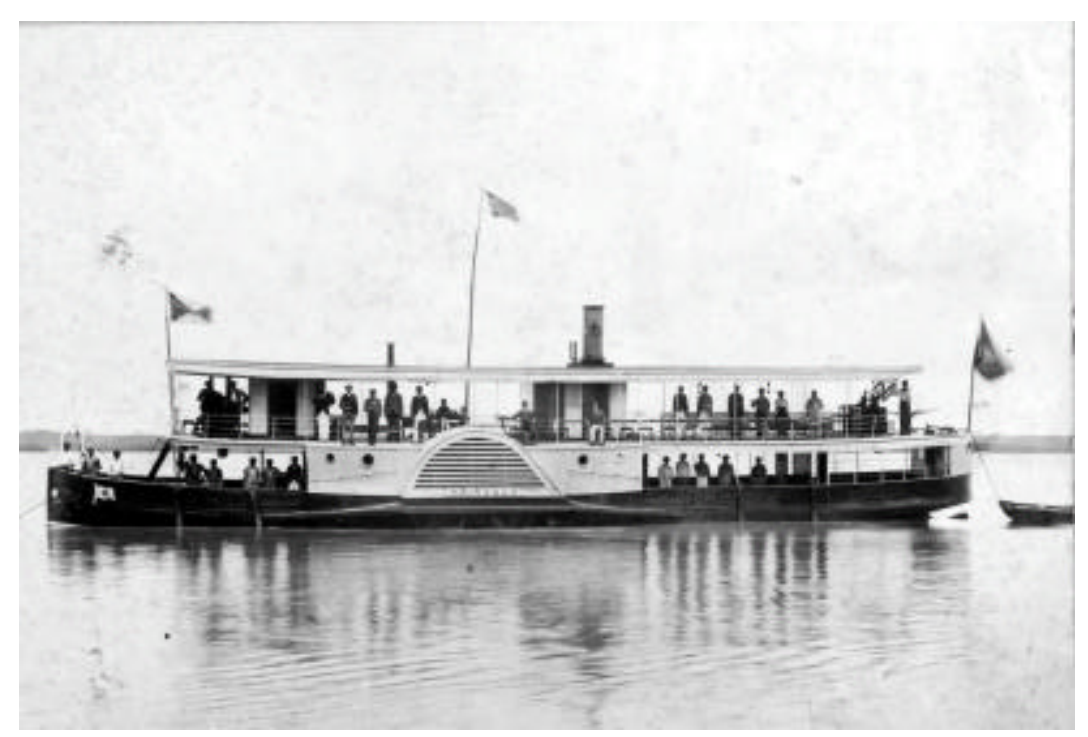

Fotografia 2 - Embarcação Ipiranga. Album..., s.n.p., gelatina/prata, 15 x $20 \mathrm{~cm}$, MHAM.

\footnotetext{
${ }^{41}$ A categoria transeunte tem o sentido próximo ao adotado pela antropóloga Fraya Frehse (2005, p. 37) em suas pesquisas sobre o cotidiano nas ruas de São Paulo do século XIX. Na documentação utilizada pela autora para fundamentar sua interpretação, os transeuntes podem ser [...] "passageiros", "moradores", em trânsito pelas ruas ou encostados nos peitoris das janelas de suas residências [...]. Ver: FREHSE, Fraya. O tempo das ruas. São Paulo: Edusp, 2005, p. 36- 40, 91 e 92 e a tese de doutorado da autora: FREHSE, Fraya. Vir a ser transeunte: civilidade modernidade nas ruas da cidade de São Paulo (entre o início do século XIX e início do século XX). Tese (Doutorado em Antropologia) - FFLCH-USP, São Paulo, 2004.

${ }^{42}$ BARTHES, Roland. A câmara clara. Rio de Janeiro: Nova Fronteira, 1984.
} 
O Maranhão - em especial São Luís - se sobressai imponente no álbum, com seus palácios e igrejas, em meio a rios, mares e matas. Nesse cenário, há vários diálogos que podem ser estabelecidos, dependendo do tempo, lugar e grupo sócio-cultural em que o observador esteja.

No cenário montado por Gaudêncio Cunha, há embarcações com pessoas bem trajadas dentro delas. As naus estão como que posando para o fotógrafo nos mares e rios e em meio a matas selvagens. Esses cenários remetem- me ao sonho do persona gem Brian Sweeney Fitzgerald do filme Fitzcarraldo ${ }^{43}$ e o seu desejo de montar uma ópera Ocidental em plena Selva Amazônica. Fazem-me pensar, ainda, em passagens do realismo mágico de Garcia Márquez ${ }^{44}$ em que personagens de perfil ocidental emergem em ambientes selvagens da Amazônia Colombiana, dando origem a situações de aparência fantástica.

Olhar uma fotografia é como dialogar consigo mesmo, com seus sentimentos, expectativas, com os livros e filmes internalizados na adolescência. E dentro desse intercâmbio, cada um é compelido a fazer leituras diversas.

O que Kossoy chama de segunda realidade tem relação, a princípio, somente com o diálogo estabelecido entre o observador e a fotografia, enquanto construção simbólica. Mas, situações similares acontecem na relação entre observadores e formas simbólicas diversas em campos variados como o da história, literatura, religião, arquitetura, pinturas e esculturas.

Os irmãos Augusto e Haroldo de Campos ${ }^{45}$, por exemplo, na análise que fizeram da obra do poeta maranhense Sousândrade ${ }^{46}$ - lembram que "a arte grega então sobrevive, porém desacompanhada da forma grega de vê-la" ${ }^{47}$. O que eles quiseram dizer é que símbolos da Grécia Antiga foram usados de várias maneiras ao longo dos séculos, independente do seu significado original. A arte clássica grega foi vista, ao longo do tempo, de acordo com as expectativas e necessidades consideradas apropriadas. Algo semelhante

\footnotetext{
${ }^{43}$ Fitzcarraldo é um filme dirigido e produzido pelo alemão Werner Herzog em 1982. Filmado no Brasil e no Peru. Duração 2h37min. Com Klaus Kinski (1926-1991), Claudia Cardinale e José Lewgoy (1920-2003). Ganhou o prêmio de Melhor Diretor no Festival de Cannes de 1982. Conta momentos do irlandês Brian Sweeney Fitzgerald - os índios chamavam-no de Fitzcarraldo - na cidade amazônica de Iquitos, Peru, no final do século XIX. O sonho dele era levar uma grande ópera ocidental para essa cidade, onde pretendia construir um teatro em plena selva amazônica. A inauguração seria com a presença de intérpretes líricos vindos da Europa. A cena mais impressionante é a de uma grande embarcação, puxada em terra por dezenas de índios, na Amazônia, ao som da voz do tenor italiano Enrico Caruso.

${ }^{44}$ Ver obras de Gabriel García Márquez, dentre as quais: MÁRQUEZ, Gabriel G. Cem anos de solidão. Rio de Janeiro: Sabiá/Vozes, 1972; e MÁRQUEZ. Gabriel G. O Amor nos Tempos de Cólera. Rio de Janeiro: Record, 2001. Escritor colombiano, Márquez nasceu em 1928 e ganhou o prêmio Nobel de Literatura em 1982.

${ }^{45}$ CAMPOS, Augusto de; Haroldo de. ReVisão de Sousândrade. Rio de Janeiro: Nova Fronteira, 1982.

${ }^{46}$ Sousândrade viveu no tempo em que Gaudêncio Cunha esteve no Maranhão. Ver WILLIAM, Frederick G; MORAES Jomar. Poesias e Prosas reunidas de Sousândrade. São Luís: AML/UFMA/Fundação Sousândrade, 2003, p. 524-525 e CAMPOS, Augusto de; Haroldo de. ReVisão de Sousândrade. Rio de Janeiro: Nova Fronteira, 1982, p. 474-477.

${ }^{47}$ CAMPOS, op. cit., p. 297.
} 
acontece com frequiência na relação entre a fotografia e o receptor: as interpretações sobre o conteúdo das imagens apresentam-se indistintas do seu significado formador, de acordo com interesses momentâneos.

\section{c) O olhar do Historiador}

O historiador, ao trabalhar a fotografia como fonte histórica, transforma-se num intérprete da primeira realidade. Ao contrário dos que têm a oportunidade de olhá-la confortavelmente instalado em sua contemporaneidade, no espaço da segunda realidade, ele interpreta os fatos históricos de onde se encontra, mas apoiado em fontes históricas. Vai à procura dos vestígios da Primeira realidade que nunca mais se repetirá.

Houve tempos em que os historiadores acreditavam que estavam recuperando a história, embora estivessem apenas construindo relatos baseados em evidências que eles localizavam somente em fontes históricas escritas e oficiais ${ }^{48}$. Num outro momento epistemológico, quando já era corrente a impossibilidade de repetição do passado, várias polêmicas ocorreram no campo da historiografia. Fernando Catroga ${ }^{49}$ chegou até a encontrar semelhanças entre a escrita da história e o culto à morte: "[...] assim como a visita ao cemitério é ato memorial de re-presentificação - suscitado a partir de 'sinais' que referenciam um 'objeto ausente' - também a escrita (e a leitura) da história se constrói a partir de traços e de representações que visam situar, na ordem do tempo, algo que se sabe ter existido, mas que já não existe [...]"50.

O historiador assume o ofício de interpretar o passado, usando fontes históricas. Só que ele - seja qual for a fonte em que esteja lastreado - fala de dentro de uma sociedade, estabelecida em um tempo e espaço e que influencia na sua interpretação. É por isso que Jacques Le Goff ${ }^{51}$ diz que a história não é uma ciência como as outras, pois vive no reino do inexato: "quer ser objetiva e não pode sê-lo; quer fazer reviver e só pode reconstituir".

\footnotetext{
${ }^{48}$ Esses historiadores foram denominados de participantes da história tradicional ou da história-relato e também chamados historicistas. Jacques Le Goff situa o surgimento do historicismo no fim do século XVIII e início do século XIX, na chamada Escola Prussiana, influente na historiografia Ocidental no século XIX. Espalhou-se pela Europa, aliando-se às linhas de pensamento positivistas e idealistas. Os historiadores dessa corrente restringiam sua abordagem aos grandes acontecimentos políticos, os quais eram vistos como imutáveis e definitivos. Usavam a metodologia histórica pautada em relatos cronológicos e respaldavam-se apenas em documentos escritos oficiais cuja veracidade em nenhum momento era questionada. Ver: LE GOFF, Jacques. Memória. In: Enciclopédia Einaudi. Vol. I: Memória e História. Lisboa: Imprensa Nacional/Casa da Moeda, 1984, p. 204-205; BRAUDEL, Fernand. História e Ciências Sociais. Lisboa: Presença, 1972, p. 90-120.

${ }^{49}$ CATROGA, Fernando. Memória, história e historiografia. Coimbra: Quartetos, 2001.

${ }^{50}$ Ibid., p. 41-42.

${ }^{51}$ BARTHES, Roland. A câmara clara. Rio de Janeiro: Nova Fronteira, 1984. p. 161.
} 
A reconstituição histórica, apesar de pautar-se em fontes documentais diversificadas, carrega a visão do historiador, portanto, é uma interpretação. O historiador parte do presente para pôr questões ao passado. Le Goff ${ }^{52}$, citando Benedetto Croce, expurga a idéia de existir objetividade da narrativa histórica quando afirma: “[...] toda história é bem contemporânea, à medida que o passado é apreendido no presente e responde, portanto, aos seus interesses, o que não é só inevitável, como legítimo".

Para Le Goff ${ }^{53}$, “o discurso histórico não segue o real, apenas o significa”. O historiador deve retirar dos documentos tudo o que eles contêm, mas nada deve acrescentar ao que neles não esteja contido. Isso porque os elementos mais necessários à história são as consequiências, as circunstâncias que rodeiam os fatos e, principalmente, as suas causas. O historiador não tem o direito de prosseguir uma demonstração, de defender uma causa, seja ela qual for, a despeito dos testemunhos. Deve somente estabelecer e evidenciar a verdade ou o que julga ser verdade. Mas é impossível, para ele, ser objetivo, abstrair-se de suas concepções. A sua assinatura o torna responsável pelo que escreveu; a sua escrita é na primeira pessoa e a transitoriedade histórica confunde-se com a sua assinatura.

$\mathrm{Na}$ análise que faz das relações entre o presente e o passado, Le Goff ${ }^{54}$ defende a idéia de que "cada época fabrica mentalmente a sua representação do passado histórico" 55 . Resta para a história, portanto, somente essa possibilidade porque o passado ocorre uma só vez e é impossível reconstruí-lo. Com base em indícios, o máximo que se pode fazer é reconstituí-lo. E, ainda assim, com o devido cuidado de distinguir as particularidades das fontes históricas, pois os documentos nunca são puros e objetivos, inclusive a fotografia.

Como fonte indiciária, a fotografia é cada vez mais usada entre aqueles que interpretam aspectos da história cultural, seja qual for a sua temática: educação, vida cotidiana doméstica, vida cotidiana nas ruas, violência, situação da mulher ou trabalho.

A idéia de índice não é uma característica inerente somente à fotografia e a outros documentos históricos. É usada nas mais distintas ramificações do saber, tais como Direito, Psicanálise, Medicina, Segurança (investigações policiais), Jornalismo, Arqueologia e Biologia. Assume nomes variados: indício, sintoma, pauta, suspeita, pista, sinal, ato falho, rastro, resquícios, entre outros. Os aspectos epistemológicos desse fenômeno vêm sendo observados com mais atenção nos últimos anos.

\footnotetext{
${ }^{52}$ BARTHES, Roland. A câmara clara. Rio de Janeiro: Nova Fronteira, 1984. p. 181.

${ }^{53}$ Ibid., p. 172.

${ }^{54}$ Ibid.

${ }^{55}$ Ibid., p. 164.
} 
Nos estudos sobre índice, Ginzburg ${ }^{56}$ menciona a experiência criada pelo médico italiano Giovanni Morelli no final do século XIX para diferenciar pinturas originais das falsificações. Morelli se valia de marcas pessoais deixadas pelo autor em detalhes de pinturas para identificar as originais. Essas minúcias pictóricas eram o diferencial que particularizava as obras; os detalhes imperceptíveis que fugiam às tendências artísticas dominante no conjunto da obra. Era o diferencialque conduzia a investigação.

O uso do indiciário por Morelli chamou a atenção de Sigmund Freud (1856$1939)^{57}$, que lhe garante um lugar especial na formação da história da psicanálise. No ensaio que fez sobre Moisés, a célebre escultura feita por Michelangelo (1475-1564), Freud vê a idéia de Morelli como um método que “[...] tem por hábito penetrar em coisas concretas e ocultas através de elementos pouco notados ou despercebidos, dos detritos ou 'refugos' da nossa observação [... $]^{, 58}$.

A idéia de índice ganhou força no Brasil entre historiadores culturais na década de 1990 e início do século XXI, inclusive entre os que exploram o tema história da fotografia ou usam a fotografia como fonte primordial ${ }^{59}$. Peter Burke ${ }^{60}$ mesmo não arriscando indicar um único período para a descoberta da história cultural, afirma que essa forma de abordagem da história passou a ter maior visibilidade mundial na década de 1970 . Para ele, as representações são o que mais deve inquietar o historiador cultural:

O terreno comum dos historiadores culturais pode ser descrito como a preocupação com o simbólico e suas interpretações. Símbolos, conscientes ou não, podem ser encontrados em todos os lugares, da arte à vida cotidiana, mas a abordagem do passado em termos de simbolismo é apenas uma entre outras. Uma história cultural das calças jeans, por exemplo, é diferente de uma história econômica sobre o mesmo tema, assim como uma história cultural do parlamento seria diversa de uma história política da mesma instituição $[\ldots]^{61}$.

Na concepção de Burke, a história cultural não tem a pretensão de apreender o social como uma totalidade hierarquizada. Chartier ${ }^{62}$, por sua vez, afirma que a representação, como base da história cultural, é "uma teia de relações complexas, onde cada

\footnotetext{
${ }^{56}$ GINZBURG, Carlos. Sinais: raizes de um paradgma indiciário. In: Mitos, emblemas e sinais. São Paulo: Companhia das Letras, 2003. p. 143-179.

${ }^{57}$ Ibid., p. 143-179.

${ }^{58}$ Ibid., p. 147.

59 As pesquisas que utilizam fotografia como vem crescendo em áreas como a história da educação e em estudos sociológicos e antropológicos. Cito dois exemplos: THIELEN, Eduardo V. Imagens da saúde no Brasil. Dissertação de mestrado em História. PUC/SP. São Paulo, 1992. Nessa obra, o autor utilizou imagens fotográficas para investigar atividades de saúde pública realizadas pelo Instituto Osvaldo Cruz nas décadas de 1910 e 1920. Em EDLER, Flávio C. Boticas \& farmácias. Rio de janeiro: Casa da Palavra, 2006, fontes iconográficas como fotografias e rótulos de produtos farmacêuticos foram privilegiadas como pistas para historiar as boticas e farmácias brasileiras.

${ }^{60}$ BURKE, Peter. O que é história cultural. Rio de Janeiro: Zahar, 2005.

${ }^{61}$ Ibid., p. 10.

${ }^{62}$ CHARTIER, Roger. História cultural: entre práticas representações. Lisboa: Difel, 1988. p. 83.
} 
indivíduo se encontra inscrito de múltiplas formas, as quais são todas culturalmente construídas".

Isso significa que as particularidades inerentes às práticas culturais podem ser sobrepostas às hierarquias e divisões sociais. É próximo ao que Lloyd ${ }^{63}$ explica ao afirmar que a cultura pode não coincidir inteiramente com a estrutura social vigente, com a organização econômica ou prática política. Isso, contudo, de forma alguma inviabiliza uma interpretação que considere parâmetros estruturais como os que identificam mentalidades de curta, média e longa duração ${ }^{64}$.

Chartier ${ }^{65}$, nos seus estudos sobre a história cultural, compreende a representação como a prática de uma idéia. Ele passeia pelos campos do imaginário social, e chega a dizer que "a identidade do ser não seja outra coisa senão a aparência da representação, isso é que a coisa não existe a não ser no signo que a exibe". Para ele, o espaço representativo e a realidade se entrelaçam a ponto da "aparência valer pelo real" 66 . O autor elucida sua proposição citando o exemplo dos médicos que têm a necessidade de vestir becas largas e os magistrados de trabalharem em palácios e usarem trajes suntuosos.

Se aqueles últimos detivessem a verdadeira justiça e os médicos possuíssem a verdadeira arte de curar, não teriam a necessidade de barretes quadrados; a majestade dessas ciências seria por si própria suficientemente vulnerável. Mas lidando apenas com ciências imaginárias, é-lhes necessário lançar mão desses instrumentos que impressionam a imaginação daqueles com que têm a tratar; e é desse modo, que se dão ao respeito $[\ldots]^{67}$.

Ressalvando, evidentemente, a prática ética dos médicos e magistrados, vale extrair do exemplo de Chartier a constatação de que existe uma trama permeando a representação. E a finalidade da trama é quase sempre fazer prevalecer a idéia de um grupo sobre a dos outros. "Usam signos visíveis como provas de uma realidade que não o é"68. Tem a ver com uso ideológico ou manipulado da fotografia - comum nas chamadas fotografias encomendadas -, um aspecto que Kossoy ${ }^{69}$ retoma com freqüência. Para o historiador brasileiro, a fotografia resulta de uma finalidade, que contempla desde pequenos desejos e ansiedade de uma pessoa comum até as complexas contexturas que sustentam instituições sociais como as exemplificadas por Chartier.

\footnotetext{
${ }^{63}$ LLOYD, Christopher. As estruturas da história. Rio de janeiro: Jorge Zahar, 1995.

${ }^{64}$ BRAUDEL, Fernand. História e ciências sociais. Lisboa: Presença, 1972.

${ }^{65}$ CHARTIER, Roger. História cultural: entre práticas representações. Lisboa: Difel, 1988. p. 19-20.

${ }^{66}$ Ibid., p. 20.

${ }^{67}$ Ibid., p. 22.

${ }^{68}$ Ibid., p. 22

${ }^{69}$ KOSSOY, Boris. Construção e desmontagem da informação fotográfica: teoria e história. Revista USP, n. 62, p. $224-$ 232, jun./ago. 2004b. p. 225, 231-232; 2003 p. 101-115; 2000, p. 82.
} 
Nessa concepção, o Album do Maranhão em 1908 é bem mais do que a simples presentificação de paisagens que existiram no passado. Considerando o pensamento de Chartier e de Kossoy, o álbum é, sobretudo, uma pista sobre o que se pensava nos primórdios da República Brasileira. Um tempo em que a sociedade ansiava por uma modernidade redentora, ao mesmo tempo em que, no Maranhão, se sentia a necessidade de manter uma reverência ao que seria um passado de glórias vividos na primeira metade e meados do século XIX. No álbum de 1908, o moderno almejado pelo nascente regime republicano emerge em um cenário cercado de contingências do passado. É Gaudêncio Cunha, em sua introspecção, que endossa essa forma de olhar o mundo.

De maneira alguma, há preocupação de se identificar 'precisões' estruturantes que, para alguns, por si só, conduziriam as relações sociais. Ao seguir por essa linha, há o risco de se ignorar manifestações culturais, fundamentais para a compreensão da história e interpretação do conteúdo do álbum. Isso, contudo, de forma alguma significa olhar o álbum de 1908 como um documento que oculta a realidade. A seleção de conteúdos estabelecidos por Gaudêncio Cunha manifesta ideais que circulavam em seu tempo.

Apesar de ser uma encomenda solicitada por um governo que tinha à frente um político conservador, representante das elites dominantes da época, o álbum de 1908 diferese de uma ficção, da forma como esse termo é colocado por $\operatorname{Kossoy}^{70}$, quando ele chama a atenção para o uso ideológico da fotografia.

Gaudêncio Cunha atendeu às pretensões do seu cliente e no álbum prepondera a imagem de um Maranhão de perfil europeu, emoldurado por elementos da modernidade de sua época. Só que o fotógrafo faz mais do que atender a uma encomenda. O álbum de 1908 traz em si o pensamento vigente e regente no Brasil de sua época, com as particularidades culturais inerentes ao Maranhão. O que é diferente de uma simples manipulação ideológica, como aconteceu com a fotografia em vários momentos ao longo de uma trajetória ${ }^{71}$.

As fotografias que compõem o álbum de 1908 suscitam várias perguntas. No processo investigativo, pairara sempre no ar o porquê da presença de paisagens de São Luís do Maranhão carregadas de nostalgia, ao mesmo tempo em que eram adicionados símbolos da modernidade circulante no Brasil do início do século XX.

O que levou Gaudêncio Cunha a incluir conteúdos que remontam aos tempos do Império e da Colônia, como os chafarizes de avenidas e praças de São Luís (Fotografia 14 e

\footnotetext{
${ }^{70}$ KOSSOY, Boris. Os tempos da fotografia: o efêmero e o perpétuo. Cotia: Ateliê Editorial, 2007. p. 54

${ }^{71}$ Ibid., p. 103-127, 136-143.
} 
28) ao lado de ícones da modernidade do início século XX, como a Companhia de Bombeiros (Fotografias 51 e 52)?

Velhas ruas estreitas da capital maranhense, como a Rua 28 de Julho, conhecida, também, Rua do Giz (Fotografia 58) com seus casarões erguidos no final do século XVIII e na primeira metade do século XIX são destacadas nas fotografias. Isso mesmo sendo o álbum de 1908 uma publicação criada no início da fase republicana, um tempo em que o Brasil já tinha como parâmetro de urbanidade as largas avenidas, bem ao estilo parisiense, o modelo preferencial da época.

Nesse mesmo período, o Rio de Janeiro, onde aconteceu a Exposição Nacional, acabava de ter parte de sua estrutura urbana modernizada pelo prefeito Francisco Pereira Passos (1836-1913). Ruas estreitas foram substituídas por largas avenidas. Aliás, necessidade de apresentar esse novo Rio Janeiro como cartão-postal do Brasil seria uma das causas que motivaram a montagem da Exposição Nacional. Evidente que os organizadores tinham a intenção primordial de apresentar nos pavilhões da exposição de 1908 a produção do que seria um novo Brasil, republicano e moderno.

Duas categorias serão utilizadas com freqüência no trabalho: modernidade e urbanismo, e suas variações semânticas. A idéia de Modernidade de certa forma engloba a urbanização. A origem dos dois fenômenos remonta ao Renascimento e até mesmo a momentos isolados anteriores a essa fase, de acordo com Koyré ${ }^{72}$. Padre Antônio Vieira ${ }^{73}$, ao final dos seiscentos, incluiu o termo moderno como diferencial de antigo "[...] fenão os que hoje, nos tempos mais chegados a nòs fe chamão modernos [...]",74.

O termo 'modernidade' e suas variantes serão utilizados no decorrer da pesquisa, buscando em alguns momentos contextualizá-lo historicamente ou através de recursos filosóficos. Isso por dois motivos. Primeiro porque se trata de uma categoria complexa, principalmente por ter o devir como uma de suas características mais marcantes. Segundo porque é um termo ligado às origens e trajetórias da fotografia. A princípio vale lembrar que se vivenciou no Brasil uma modernidade tardia, apesar da ocupação européia ter iniciado a partir do século XVI, quando a modernidade já havia florescido na Europa.

No campo da filosofia, é interessante colocar a observação elaborada por Koyré ${ }^{75}$ de que o moderno passou a ser sempre o que é atual: a novidade vigente em um tempo e espaço e dentro de um grupo social. "[...] somos sempre modernos em qualquer época,

\footnotetext{
${ }^{72}$ KOYRÉ, Alexandre. Estudo de História do Pensamento científico. São Paulo: Forense, 1991.

${ }^{73}$ VIEIRA, Padre. História do futuro. Belém: Secult/IOE/Prodepa, 1998.

${ }^{74}$ Ibid., 1998, p. 244. A citação encontra-se redigida com a grafia original.

${ }^{75}$ KOYRÉ, op. cit., 1991.
} 
quando pensamos mais ou menos como nossos contemporâneos, mas de modo diferente do saber que nos foi ensinado [...]"76. Assim, o que é modernidade em uma época pode ser ultrapassado em um momento seguinte. É dessa maneira que o termo e suas variações estão sendo aplicados com mais freqüência nessa pesquisa.

O termo urbanismo, que também será retomado em termos explicativos ao longo da pesquisa, foi criado em 1867. É uma criação do engenheiro espanhol Ildefonso Cerdà para justificar as decisões que ele adotara em planos de expansão de Barcelona em $1859^{77}$. Há uma diferença entre o urbanismo, que é mais usado para denominar a disciplina que estuda a cidade e o termo urbanização que seriam a reuniões de construções onde seus habitantes se encontram, se ajudam e se defendem ${ }^{78}$. Nessas duas palavras e em outras semelhantes, como urbanidade, serão aplicadas ao que se refere à cidade como as obras públicas, morfologia urbana, planos urbanos, práticas sociais e pensamento urbano, legislação e direito relativo à cidade $[\ldots]^{79}$.

Para Le Goff ${ }^{80}$, as cidades, no Ocidente, começaram a se estruturar na Europa da Idade Média. As mutações pelas quais passou a sociedade feudal levaram ao surgimento do Renascimento e à consolidação do que passou a ser modernidade. Nesse período, os burgos medievais se consolidavam, gradativamente, como espaços de direitos, de cunho econômico e de justiça ${ }^{81}$ dando origem a cidades européias.

\section{Mapeamento do campo temático}

O mapeamento das publicações sobre a história da fotografia no Maranhão e, especificamente, sobre Gaudêncio Cunha e o Album do Maranhão em 1908 fundamenta-se na apreensão de que o tratamento de um tema deve ocorrer em concordância com o seu campo historiográfico. Essa etapa da pesquisa faz parte da análise técnico-iconográfica. Cabe realçar a importância da revisão do campo temático, pois se constitui de levantamento sobre a existência ou não de bibliografia histórica sobre o assunto, quem escreveu, onde, quando e como.

Considerando a concepção de que o fato histórico é uma construção, reitero que o historiador utiliza critérios de classificação, análise, interpretação e crítica das informações

\footnotetext{
${ }^{76}$ KOYRÉ, Alexandre. Estudo de História do Pensamento científico. São Paulo: Forense, 1991. p. 15-16.

${ }^{77}$ CHOAY, Françoise. A regra e modelo. São Paulo: Perspectiva, 1985. 1985, p. 3 e 266.

${ }^{78}$ Ibid., p. 267.

${ }^{79}$ HAROUEL, Jean-Lous. História do urbanismo. Campinas: Papirus, 1990, p.8.

${ }^{80}$ LE GOFF, Jacques. Por Amor às cidades. São Paulo: UNESP, 1988.

${ }^{81}$ Ibid., p. 16.
} 
coletadas para exprimir a configuração do campo. Nesse sentido, serão focalizados os aspectos mediante os quais a constituição temática foi efetivada.

Os campos de pesquisa são organizações relativamente autônomas que constituem a formação do espaço social, portanto, não podem ser remetidos a uma única lógica de explicação da realidade. Gozando de relativa autonomia, o campo credencia os discursos organizadores de sua lógica interna, estabelecendo o que deve e o que não deve nele se inserir. Essa lógica guarda sua perversidade, dado que, ao credenciar algo em um campo, outros aspectos, evidentemente, são rejeitados.

Burke recorre a Michel Foucault ${ }^{82}$ para definir os discursos "[...] como práticas que sistematicamente constroem (Forment) os objetos de que falam”. Para Foucault ${ }^{83}$, há sempre apropriações nos discursos, por mais livres que possam parecer.

Especificamente sobre Gaudêncio Cunha e o Album do Maranhão em 1908 foi localizado um trabalho científico de autoria de Silva Filho (2006). Foram, ainda, localizadas informações sobre o fotógrafo no texto introdutório de autoria de Jomar Moraes, de um álbum lançado na década de $1980^{84}$ com reproduções das fotografias extraídas do Album do Maranhão em 1908. Gaudêncio Cunha, também, é citado no Dicionário HistóricoFotográfico Brasileiro ${ }^{85}$.

Com relação à história da fotografia maranhense, foram consideradas relevantes quatro pesquisas que adotam imagens fotográficas como fonte histórica proeminente ou trafegam por momentos da história da fotografia do século XIX e início do século XX. Todas são produções acadêmicas. Há três monografias, sendo uma de graduação e duas de especialização e uma dissertação de mestrado.

- SILVA FILHO, José Oliveira da. Olhos de ver: a cidade entre as retóricas do visual e do escrito. Monografia de especialização. (Especialização em História do Maranhão) - CECEN/UEMA, São Luís, 2006;

\footnotetext{
${ }^{82}$ BURKE, Peter. O que é história cultural. Rio de Janeiro: Zahar, 2005. p. 102

${ }^{83}$ FOUCAULT, Michel. A ordem do discurso. São Paulo: Loyola, 2004, p. 40.

${ }^{84}$ As fotografias que compõem o Album do Maranhão em 1908 foram reproduzidas num álbum publicado em 1988 por iniciativa do escritor Jomar Moraes, que, à época, era Secretário Estadual de Cultura e presidente da Academia Maranhense de Letras. A sua intenção foi a de preservar o único exemplar do álbum de manuseios para consulta e divulgar as imagens fotográficas do Maranhão do início do século XX. Nessa publicação, Moraes fez uma introdução na qual tece um breve relato sobre fotógrafos que trabalharam no Maranhão no século XIX e início do século XX, destacando Gaudêncio Cunha (SARDINHA, 1987).

${ }^{85}$ KOSSOY, Dicionário histórico-fotográfico brasileiro: fotógrafos e ofício da fotografia (1833-1910). São Paulo: Instituto Moreira Salles, 2002. p. 116-117.
} 
- MENDONÇA Edinamária C. "Representações sociais em fatos culturais: o Álbum Commemorativo do $3^{\circ}$ Centenário da Fundação da Cidade de São Luís, Capital do Estado do Maranhão”. In: MARQUES, Francisca E. de S. Jornalismo cultural: da memória ao conhecimento. São Luís: UFMA/ Chamamaré/NEEC, 2005. p. 113-140;

- MATOS, Marcos Fábio Belo. ... E o cinema invadiu Athenas: história do cinema ambulante em São Luís. São Luís: Faculdade UNISÃOLUÍS, 2002;

- BARROS, Valdenira. Imagem do moderno em São Luís. São Luís: Unigraf/Studio Edgar Rocha, 2001.

Preponderou no Maranhão, até o fim da década de 1970, uma concepção de narrativa histórica delimitada pela cronologia factual e muito restrita a temas políticos e econômicos ${ }^{86}$, construídos com base em fontes escritas oficiais (documentos produzidos pelos poderes públicos e pelas instituições representativas do meio empresarial).

Na década de 1980, as narrativas históricas no Maranhão absorveram aspectos metodológicos que contemplam temporalidades diferenciadas da cronologia factual; as fontes e os temas foram diversificados, iniciando-se, gradativamente, a inserção da cultura como campo historiográfico ${ }^{87}$.

As novas pesquisas sobre a história envolvendo o Maranhão estão vinculadas, em sua maioria, a professores e historiadores formados pelos cursos de história das universidades Federal e Estadual do Maranhão que procuraram aprimorar seus estudos em universidades de outros estados. Mas, também se fez presente entre pesquisadores de outras áreas do saber acadêmico como a Antropologia e Sociologia, Comunicação Social, História da Educação e Psicologia Social ${ }^{88}$.

As quatro pesquisas citadas foram incluídas na análise historiográfica por apresentarem, de alguma forma, aspectos sobre a fotografia maranhense do século XIX e

\footnotetext{
${ }^{86}$ Entre os historiadores que centralizaram suas temporalidades na cronologia factual dos fatos político-administrativos.

${ }^{87} \mathrm{Na}$ década de 1980, as narrativas históricas no Maranhão começaram a romper com a história tradicional ao absorverem aspectos metodológicos marxistas e da Nova História. Essas narrativas resultam, em sua grande maioria, de teses e dissertações de professores e alunos dos cursos de História e de Ciências Sociais da Universidade Federal do Maranhão (UFMA) e História da Universidade Estadual do Maranhão. As teses e dissertações, em geral, foram defendidas em universidades de outros estados, principalmente em programas de pós-graduação da Universidade Federal do Pernambuco, Universidade de São Paulo, Universidade Federal Fluminense e na Universidade Estadual de Campinas (Unicamp).

${ }^{88}$ A partir da década de 1980, pesquisadores de várias áreas, principalmente antropólogos e sociólogos, também abordaram a história cultural maranhense em suas pesquisas, fundamentando-se em autores de suas áreas de conhecimento.
} 
princípio do XX. Chamou a atenção de Mendonça, Matos e Barros a ação dos conteúdos modernos presentes das imagens.

Silva Filho ${ }^{89}$ volta seu olhar exatamente para o Album do Maranhão em 1908, mas opta em tocar pouco no tema modernidade da época presente no conteúdo das imagens. Esse assunto é chave na minha interpretação, principalmente porque compõe as fotografias, juntamente com o que permaneceu, no início do século XX, dos tempos da Colônia/Império no Maranhão.

$\mathrm{O}$ autor identificou-se mais com os simbolismos e relações sócio-culturais que encontrou circulando pelas ruas e praças representadas nas fotografias. Concordo quando ele afirma que as fotografias do álbum de 1908 privilegiam a área de São Luís que recebia mais a atenção do poder público "[...] no que diz respeito à melhoria e conservação dos espaços [...]" ${ }^{\prime 90}$, o que não podia ser diferente, em se tratando de uma encomenda do Governo do Maranhão.

Entre os locais analisados por Silva Filho ${ }^{91}$ estão o Largo do Carmo, um dos pontos mais importantes da cidade, a "menina dos olhos" do governador Benedito Leite. O autor detalha o conteúdo das fotografias da Rua do Egito, Portugal, Estrela, Grande, Afonso Pena, Giz (ou 28 de Julho), Passeio, São Pantaleão, Sol, Avenida Maranhense e as duas avenidas na área do Quartel. Ele aponta os mitos desses logradouros, incluindo os ilustres escritores que residiram nesses locais. Chamou também sua atenção o estado de preservação dessas vias, seus calçamentos, o que o fotógrafo atenuou e tentou omitir nesse sentido.

Silva Filho ${ }^{92}$ dedica atenção especial à participação do Maranhão na Exposição de 1908 no Rio de Janeiro, tendo, como uma de suas bases empíricas, o relatório do comissário da Delegação Maranhense, Domingos Perdigão, presentado ao Governo do Maranhão em 1908. Com base nesse e em outros documentos, ele interpreta momentos interessantes do comparecimento maranhense na Exposição de 1908, no Rio de Janeiro.

A minha impressão é que as pessoas que aparecem distantes nas imagens do álbum incomodaram Silva Filho ${ }^{93}$. Ele deixa transparecer isso nas entrelinhas de seu trabalho. No meu caso, centro mais as atenções nas edificações que dominam os conteúdos fotográficos.

\footnotetext{
${ }^{89}$ SILVA FILHO, José Oliveira da. Olhos de ver: a cidade entre as retóricas do visual e do escrito. Monografia de especialização. (Especialização em História do Maranhão) - CECEN-UEMA, São Luís, 2006.

${ }^{90}$ Ibid., p. 42.

${ }^{91}$ Ibid., p. 40-41, 57.

${ }^{92}$ Ibid.

${ }^{93}$ Ibid.
} 
O trabalho de Edinamária Mendonça é uma das 16 pesquisas reunidas por Francisca Ester de Sá Marques na publicação Jornalismo Cultural: da Memória ao Conhecimento. A base empírica da pesquisa é o Album Commemorativo do $3^{\circ}$ Centenário de fundação da Cidade de São Luiz capital do Estado do Maranhão ${ }^{94}$. O álbum rememora, em 1913, a festa de comemoração dos 300 anos de fundação de São Luís ocorrida no ano anterior.

Mendonça ${ }^{95}$, também, percebe no Álbum do Tricentenário, entre outras visões, referências a um passado de glórias maranhenses convivendo de maneira pacífica com a modernidade do presente. São antagonismos que, para ela, não se chocam, mas se complementam.

O livro... E o Cinema invadiu Athenas: história do cinema ambulante em São Luís, Marcos Fábio Matos, também, enxerga a modernidade aportando em São Luís na passage m do século XIX para o XX. Tem como base a dissertação de mestrado defendida por ele, em junho de 2000, na Escola de Comunicação da Universidade Federal do Rio Janeiro. Trata-se do primeiro autor a lançar um olhar interpretativo sobre as primeiras projeções cinematográficas ocorridas em São Luís na passagem do século XIX para o XX.

A inclusão da pesquisa desse autor na análise historiográfica da fotografia maranhense tem como base as seguintes justificativas:

a) Apesar de centrar sua atenção nos primórdios das projeções cinematográficas no Maranhão, toca em momentos significantes da (para) história da fotografia maranhense;

b) O ciclo do cinema ambulante, estudado pelo autor, situa-se no espaço e período em que ocorreu a trajetória de Gaudêncio Cunha;

c) Fotografia e cinema são produtos da modernidade, sendo o primeiro prelúdio do segundo.

Em vários trechos de sua narrativa, Matos faz referências à fotografia, principalmente no que diz respeito às ligações com o cinema. Contudo, a intercalação mais surpreendente que ele faz entre as histórias da fotografia e do cinema é a descoberta do

\footnotetext{
${ }^{94}$ Ver: FONTES E REFERÊNCIAS: Álbum 5

${ }^{95}$ MENDONÇA, Ednamária C. "Representações sociais em fatos culturais; o álbum commemorativo do $3^{\circ}$ Centenário da Fundação da Cidade de São Luiz, Capital do Estado do Maranhão”. In: Marques, Francisca E. Jornalismo Cultural: da memória ao Conhecimento. São Luís: UFMA/Chamaré/NNEC, 2005, p. 113-140.
} 
fotógrafo Moura Quineau como o protagonista da primeira projeção cinematográfica organizada no Maranhão, em 9 de abril de $1898^{96}$.

Valdenira Barros selecionou três assuntos apontados como relevantes dentro das alterações urbanas e modernas ocorridas em São Luís, entre as quais, somente um insere-se na passagem do século XIX para o século XX, a que envolve as fábricas dessa época. A autora analisa o conteúdo de várias fotografias, entre as quais uma que a presença de operários é insignificante com relação ao prédio da Fábrica de Fiação de Tecidos do Rio Anil $^{97}$. O objetivo segundo ela era apresentar as fábricas da cidade, o que de certa forma acontece, também, com algumas imagens de indústrias dessa época presentes no álbum de 1908.

\section{Emersão da temática e as fontes}

A idéia de realizar essa pesquisa teve sua origem no meu trabalho como jornalista, no início da década de 1990, quando denunciei situações de abandono do Centro Histórico de São Luís. Em seguida, acompanhei etapas das restaurações de áreas desse sítio histórico-arquitetônico. Nessa segunda fase, as fotografias do Album do Maranhão em 1908 ganharam evidência ao servirem de modelo para a fixação de calçamentos e serviço de iluminação de ruas, becos, bulevares e praças e até mesmo do ambiente interno do Teatro São Luiz ${ }^{98}$.

Embora algumas fotografias do álbum tenham sido divulgadas pela mídia maranhense, pouco se conhecia sobre a concepção dessas imagens e sobre seu autor Gaudêncio Cunha. Daí a minha motivação em saber quem ele era e com quais finalidades ele fez esse álbum e o que as fotografias do álbum representam.

Hoje, depois de um longo caminho, sinto-me como se já tivesse aberto uma relação de amizade com Gaudêncio Cunha, apesar de ele ainda ser uma incógnita em vários aspectos. O historiador francês Fernand Braudel (1902-1985), em suas análises sobre a historiografia chegou a descrever Filipe II (1527-1598), rei da Espanha no século XVI, como se fosse um conhecido próximo: “[...] Vivi assim 40 anos de minha vida ao lado de Filipe II da Espanha, o rei de triste semblante. Para ser franco não gosto muito dele, mas acostumei-

\footnotetext{
${ }^{96}$ MATOS, Marcos. ... E o cinema invadiu Athenas: história do cinema ambulante em São Luís. São Luís: Faculdade São Luís/UNISÃOLUÍS, 2002, p.41-43, 45-47, 75-76.

${ }^{97}$ BARROS, Valdenira. Imagem do Moderno em São Luís. São Luís: Unigraf, 2001, p. 25.

${ }^{98}$ ANDRÉS, Luiz P; MOREIRA, Rafael; SILVA, Ronald Almeida. Centro histórico de São Luís - Maranhão - Brasil.

Patrimônio Mundial. São Paulo: Audichromo/UNESCO/SEC-MA, 1998b.
} 
me pouco a pouco com ele, com a sua presença, com seus silêncios, com sua falta de introspecção [...]",99.

Gaudêncio Cunha, para mim, também, aparentou traços de introspecção. Ele alternou longos silêncios durante a pesquisa empírica, principalmente no que se refere a sua vida particular.

Por causa das poucas pesquisas no Maranhão envolvendo a fotografia como fonte primordial ou personagem da história ficou difícil delimitar o número de fontes a serem consultadas. Foi necessário incluir um vasto número de arquivos localizados de São Luís na lista de investigação em que parecia provável a existência de pistas. Por essa causa os resultados nem sempre obtiveram êxito no que se refere a encontrar informações sobre o fotógrafo e o álbum de 1908. Procurei durante algum tempo o atestado de óbito de Gaudêncio Cunha ou de alguém próximo no Cemitério do Gavião (São Luís), por exemplo, e nada encontrei.

O campo da pesquisa de natureza teórica e empírica foi delimitado durante o andamento da análise técnico-iconográfica. As produções fotográficas (originais e reproduções) e as fontes escritas e orais, localizadas na etapa de levantamento de dados, definiram os limites temporais e espaciais e, conseqüentemente, as fronteiras do levantamento historiográfico sobre a história da fotografia maranhense.

Embora a pesquisa esteja focada na análise do Album do Maranhão em 1908 e seu autor, os levantamentos e entrevistas permitiram traçar um panorama sobre fotógrafos que trabalharam no Maranhão desde 1846 até o início do XX.

As fotografias de paisagens maranhenses mais antigas encontradas são da década de 1890. Integram o álbum Maranhão Ilustrado ${ }^{100}$ de autoria incerta, podendo ter sido de autoria de Gaudêncio Cunha. Há informações sobre a criação de imagens de paisagens e ambientes internos no Maranhão, também, na década de 1890, pelos fotógrafos Rodolpho Vasconcelos, Moura Quineau e Eduardo Wenk. Porém essa documentação não foi localizada ou identificada. Também não foram encontradas fotografias de paisagens maranhenses anteriores à década de 1890.

No início do século XX, com o progresso da reprodução fotomecânica, surgiram mais fotógrafos de paisagens, principalmente urbanas. A Revista do Norte apresenta imagens

\footnotetext{
99 BRAUDEL, Fernand. Reflexões sobre história. São Paulo: Martins Fontes, 2002, p. 331.

${ }^{100}$ Ver FONTES: Álbum 1,
} 
factuais e de paisagens criadas pelo próprio Gaudêncio Cunha e de autoria de outros profissionais como Costa Sobrinho ${ }^{101}$, de fotógrafos amadores e de clichês.

Antes na década de 1890, os registros demonstram que os fotógrafos que atuaram no Maranhão só elaboraram retratos. Eram, em sua maioria, itinerantes que percorreram o Brasil na segunda metade do século XIX. Somente depois do lançamento do Dicionário Histórico-Fotográfico Brasileiro ${ }^{102}$, eles começaram a ingressar na história. Antes, devido a diversos critérios de seleção ${ }^{103}$, apenas alguns fotógrafos do século XIX adquiriram fama em seu tempo e na história do Brasil. E nenhum desses famosos, ao que se sabe até o momento, esteve no Maranhão.

A procura por dados escritos e iconográficos foi realizada com mais ênfase em instituições ligadas ao fomento da cultura e preservação do patrimônio históricoarquitetônico do Maranhão. Durante o rastreamento, entrevistei vários profissionais entre escritores, fotógrafos em atividade no Maranhão, antropólogos, artistas, bibliotecários e historiadores. A maior parte deles trabalha nos locais onde localizei as fontes escritas e a produção fotográfica. Eles colaboraram de diversas maneiras na condução da análise iconográfica, especialmente na localização das fontes escritas e fotográficas e na indicação dos depoimentos orais ${ }^{104}$.

As fontes escritas mais importantes sobre a fotografia do século XIX e início do século XX estão em jornais e revistas de 1846 a 1920, do acervo do Setor de Obras Raras da Biblioteca Pública Benedito Leite ${ }^{105}$. Nessa documentação, foram localizadas pistas significativas sobre aspectos da vida profissional e particular de Gaudêncio Cunha e ainda insurgiram duas modalidades de informações sobre história da fotografia maranhense:

a) Crônicas que tiveram a fotografia como tema ${ }^{106}$

b) Anúncios sobre atividade de outros fotógrafos de 1846 ao início do século $\mathrm{XX}^{107}$.

\footnotetext{
${ }^{101}$ Na edição da Revista do Norte de março de 1906, o nome Costa Sobrinho identifica autor de uma fotografia; no verso de um retrato da coleção do fotógrafo Edgar Rocha há referência à sociedade Costa \& Sobrinho.

${ }^{102}$ KOSSOY, Dicionário histórico-fotográfico brasileiro: fotógrafos e ofício da fotografia (1833-1910). São Paulo: Instituto Moreira Salles, 2002.

${ }^{103}$ KOSSOY, Boris. Os tempos da fotografia: o efêmero e o perpetuo. Cotia: Ateliê Editorial, 2007. p. 63-77.

${ }^{104} \mathrm{O}$ levantamento realizou-se em arquivos dos seguintes órgãos públicos estaduais do Maranhão: Biblioteca Pública Benedito Leite, Museu Histórico e Artístico do Maranhão, MHAM (no prédio principal e no anexo: Museus de Artes Visuais). Prosseguiu no Centro de Cultura Popular Domingos Vieira Filho, Curadoria de Bens Culturais, Casa de Cultura Josué Montello e Cemitério do Gavião. A última etapa abrangeu a Secretaria de Planejamento e Desenvolvimento da Prefeitura de São Luís (com o auxílio do arquiteto José Antônio Lopes) e livraria da Academia Maranhense de Letras. Ainda houve levantamentos em coleções de particulares que serão referenciadas ao longo da pesquisa.

${ }^{105}$ No total, o acervo de jornais da Biblioteca Pública Benedito Leite reúne 446 publicações do período de 1821 até a atualidade. A opção de se fazer o levantamento somente nos periódicos do período de 1840-1910 foi determinada em função da periodização planejada para o panorama que se delineava basicamente no século XIX e princípio do XX.

${ }^{106}$ Ver: FONTES.

${ }^{107}$ Ver: FONTES.
} 
Entre as fontes orais, foram colhidas informações de pessoas que guardam retratos de seus familiares produzidos no ateliê de Gaudêncio Cunha, a Photographia União. Esses depoimentos são os mais significativos no que diz respeito às atividades desse fotógrafo.

Os fotógrafos com idade superior a 60 anos que trabalharam no Maranhão no período posterior a década de 1930, também foram entrevistados. Só que eles nada acrescentaram de novidade sobre Gaudêncio Cunha e suas atividades. Aproveitaram o momento para fazer o que gostam: conversar sobre suas próprias trajetórias fotográficas ${ }^{108}$ que aconteceram em fases da história da fotografia maranhense posteriores a Gaudêncio Cunha, uma questão que não será abordada nessa pesquisa.

$\mathrm{Na}$ área da história da fotografia maranhense, o Centro de Cultura Popular Domingos Vieira Filho (órgão da Secretaria de Cultura do Maranhão) e Fundação Nacional de Arte - Funarte (Governo Federal) realizaram no primeiro semestre de 1983, um levantamento sobre a trajetória da fotografia maranhense através do "Projeto História da Fotografia no Maranhão (1850-1950)". O projeto, mesmo ficando somente nos primeiros levantamentos de dados, reuniu entrevistas com fotógrafos e parentes de fotógrafos. Em um desses depoimentos, que será usado nessa pesquisa, há referência a Gaudêncio Cunha.

Considerável quantidade de retratos do século XIX e fotografias de paisagens da primeira metade do século XX criadas por vários fotógrafos foram localizadas durante o levantamento das fotografias produzidas por Gaudêncio Cunha. Algumas trazem identificação de autoria, mas a maioria é indeterminada.

Estão nos acervos e instituições culturais públicas ${ }^{109} \mathrm{e}$, também, em mãos de particulares. São fotografias (reproduções e originais) elaboradas no Maranhão e originais enviados ou trazidos de outros estados e países ${ }^{110}$.

\footnotetext{
${ }^{108}$ Dos cinco fotógrafos entrevistados, três sabiam da existência de Gaudêncio Cunha somente pelo fato de ele ser o autor do Album do Maranhão em 1908. Outros dois desconheciam a existência do fotógrafo em questão. Dreyfus Nabor Azoubel (1919-2002), nascido em São Luís, é o mais antigo dentre os entrevistados. Sua atividade profissional começou quando ele ainda vivia a infância ao final da década de 1920. O seu instrutor foi o próprio pai, o fotógrafo Leão Menagem Azoubel, falecido em 1951. Quando coletei o depoimento de Azoubel, em 11.06.2001, ele tinha 82 anos. Falou pouco do tempo de seu pai: "Com quatro anos eu já lavava chapa de vidro de fotografia para botar em quadro [...]". Optou em discorrer sobre épocas posteriores a sua pré-adolescência, a partir de sua primeira atividade profissional, quando acompanhou, como fotógrafo, um gravador (como se chamava o jornalista de texto na época) em uma solenidade realizada no mais importante hotel de São Luís na época. Edgar Rocha, nascido em 1942, é o mais novo e ainda está em atividade. Além de prestar depoimento, colaborou decisivamente de várias maneiras, inclusive na localização de outras produções fotográficas de Gaudêncio Cunha. Os outros fotógrafos entrevistados são: José Cordeiro da Rocha (nascido em 1928); Francisco Antônio de Souza (1928) e Ribamar Alves (1927).

${ }^{109}$ Os locais que são os órgãos públicos estaduais são os mesmo em que foram localizadas as fontes orais.

${ }^{110}$ As fotografias originais de outros estados e países estão em álbuns arquivados no Museu de Artes Visuais. O mais significativo em número de fotografias do século XIX e primeira década do século XX é o Álbum 1 da Coleção Ribeiro do Amaral. O álbum não tem título. Mede 31 x $26,5 \mathrm{~cm}$. A capa é em couro e as páginas internas em papel cartão de cor preta. $\mathrm{O}$ álbum foi higienizado e a disposição das imagens modificadas. A bibliotecária Raimunda da Graça Gonçalves Ferreira preservou a disposição anterior das fotografias no álbum, através de registro fotográfico. É provável que tenha
} 
A demanda de fotografias maranhenses do século XIX e da primeira metade do século XX é constituída por:

a) Fotografias originais arquivadas de forma avulsa ou integradas a álbuns;

b) Reproduções fotográficas em álbuns, jornais, livros e revistas ${ }^{111}$.

Os álbuns do fim do século XIX e início do século XX, tanto os que reúnem fotografias originais quanto os formados por reproduções impressas ${ }^{112}$ estão sob a guarda de órgãos públicos do Estado do Maranhão ${ }^{113}$.

Tudo indica que existe em São Luís de um vasto material fotográfico do século XIX e primeira metade do século XX correndo risco de se perder. Só a pesquisa realizada por uma equipe de cientistas sociais da UFMA, coordenada pelo antropólogo Alexandre Corrêa, sobre modos tradicionais de vida de pessoas que residem em uma área do Centro Histórico de São Luís, localizou cerca de 500 fotografias, principalmente das décadas de 1940/1950, em residências, pequenas empresas instituições como o Sindicato dos Arrumadores de São Luís.

Durante o trabalho de campo, foram várias idas e vindas entre o ato de escrever e a consulta as fontes, realizadas com o objetivo de confrontar, comparar e checar dados. Como afirma o historiador Jacques Le Goff, “o caráter científico da história reside tanto na valorização das diferenças como das semelhanças, enquanto que as ciências da ratureza procuram eliminar as diferenças" ${ }^{114}$.

\footnotetext{
sido um álbum pessoal do historiador José Ribeiro do Amaral (1853-1927), pois integrou a Coleção Ribeiro do Amaral adquirida pelo Governo do Maranhão através da Biblioteca Pública Benedito Leite junto aos herdeiros desse historiador e jornalista. O álbum foi transferido para o MHAM em 1973. Reúne duas gravuras e 128 retratos de autoridades nacionais e estrangeiras. A maioria em tamanhos aproximados a 9,0 x 6,0 cm. Algumas não trazem a procedência e outras têm oferecimento no verso. Há três fotos-pintura, sendo uma de autoria de Felipe Fidanza, famoso fotógrafo do Pará. Algumas trazem o nome da casa fotográfica e do fotógrafo proprietário. Ateliês fotográficos citados: fotografias de P. Bernadet (fotógrafo em Corrientes) e B. Laudet (Calle de la Piedad, 334 Buenos Aires), da Argentina; Berthaud (rua Cadet, 9 Paris), Photographie Charles Jacontin (Boul'de Strasbourg, 37), E. Neurdein (Editeur Photographe, Boulevard de Sebastopol, 28, Paris), Photographe Pierre Werner (Boulevard des Capachines), da França; Otávio Bolone (Rua Serra Pinto, 67, Lisboa), de Portugal; Martinez y Bidart (Cale 25 de mayo, 221, Montevideo), do Uruguai. De outros estados: Insley Pacheco (que esteve em São Luís); Justiniano José de Barros, Van-Nyvel Guimarães \& C., do Rio de Janeiro; Alberto Henschel \& $\mathrm{C}^{\mathrm{a}}$, de Pernambuco, e Fidanza \& $\mathrm{c}^{\mathrm{a}}$, de Belém - PA. Constam ainda sete fotografias produzidas no Maranhão.

${ }^{111}$ Os livros estão no setor de obras raras da Biblioteca Pública Benedito Leite e nas bibliotecas do Museu de Artes Visuais e na livraria da Academia Maranhense de Letras.

112 Ver: FONTES.

113 Ver: FONTES.

114 Jacques. Memória In: Enciclopédia Einaudi. Vol. I: Memória-História. Lisboa: Imprensa Nacional/Casa da Moeda, 1984. p. 176.
} 


\section{Desenvolvimento dos capítulos}

O Capítulo I situa o Album do Maranhão em 1908 e o seu autor, o fotógrafo Gaudêncio Cunha, na História da Fotografia e no contexto histórico de sua época, o que abrange a temporalidade, cultura e sociedade em que a obra foi construída e representa. Nesse sentido, é apresentada uma leitura preliminar do conteúdo do álbum de 1908, seguida de um estudo sobre a história do Maranhão, as descobertas da fotografia e a trajetória da fotografia no Brasil no século XIX e início do século XX.

O Capítulo II é centralizado na história de vida de Gaudêncio Cunha e na elaboração e trajetória do álbum de 1908. Primeiramente é apresentado um levantamento interpretativo sobre a fotografia produzid a no Maranhão entre 1846 e o início do século XX. Em seguida, é destacada a publicação Revista do Norte, que circulou no início do século XX com imagens de paisagens, inclusive algumas produzidas por Gaudêncio Cunha. Depois são detalhados momentos da história de vida de Gaudêncio Cunha como retratista e, por fim, as atividades dele como fotógrafo de paisagens maranhenses. Nesse último aspecto, há um destaque especial à participação do álbum de 1908 e do Maranhão na Exposição Nacional de 1908, no Rio de Janeiro.

O Capítulo III é dedicado a uma interpretação iconológica das fotografias que formam o Album do Maranhão em 1908. Primeiro é apresentada a constituição, a trajetória e o estado de conservação do álbum. Em seguida, é realizada a leitura dos conteúdos fotográficos. 


\section{CAPÍTULO I}

\section{O ALBUM DO MARANHÃO EM 1908 E A HISTÓRIA DA FOTOGRAFIA}

\subsection{O velho e o novo nas primeiras fotografias de paisagens maranhenses}

No dia 29 de agosto de 1895, quinta-feira, o jornal maranhense Federalista anunciou a inauguração no domingo, $1^{\circ}$ de setembro daquele ano, da Photographia União, localizada na Rua da Cruz, 47, entre as ruas do Alecrim e dos Afogados, em São Luís do Maranhão. Vivendo a expectativa da semana antecedente ao início de funcionamento de seu empreendimento, o proprietário do novo ateliê da cidade, o fotógrafo Gaudêncio Rodrigues da Cunha, evidenciava a intenção de atender, principalmente, à demanda de pessoas interessadas em comprar o seu retrato ou de um ente querido.

Para chamar a atenção do público, o fotógrafo proprietário da Photographia União apresentava várias vantagens aos seus clientes. Informava que dispunha "de uma máquina especial para retratos de crianças as mais travessas" e ainda oferecia a alternativa de realizar "trabalhos fora do ATELIE de qualquer natureza executa-se com a maior promptidão, mediante ajuste prévio", conforme anunciou o Federalista ${ }^{1}$.

A comercialização de retrato era a grande fonte de renda entre suas atividades da Photographia União. Aliás, essa foi uma característica marcante na vida profissional da grande maioria dos fotógrafos que trabalhou no Brasil no século XIX e nas duas primeiras décadas do século $\mathrm{XX}^{2}$. Gaudêncio Cunha certamente não fugiu à regra.

Mas, é possível que o fotógrafo, ao incluir no anúncio o seu intento de executar trabalho fora do ateliê, alimentasse, também, a pretensão de dinamizar os serviços oferecidos pela sua empresa com a venda de fotografias de paisagens maranhenses. O certo é que cinco anos e quatro meses depois da inauguração, a Photographia União, já funcionando em um novo endereço, à Rua do Sol, 30, havia incluído entre suas atividades a elaboração de álbuns com paisagens do Maranhão ${ }^{3}$.

Na primeira década do século XX, Gaudêncio Cunha lança a mais importante obra de sua carreira: o Album do Maranhão em 1908. Com esse trabalho, ele atendia a uma

\footnotetext{
129.8 .1895$.

2 Essa característica pode ser constatada através do Dicionário Histórico-Fotográfico Brasileiro (KOSSOY, 2002).

${ }^{3}$ Jornal Regeneração, 21.01.1900.
} 
encomenda do Governo do Estado que enviou o álbum para ser exibido no Rio de Janeiro na exposição comemorativa dos 100 anos de Abertura dos Portos Brasileiros às Nações Amigas ${ }^{4}$.

Foram elaborados, nas duas primeiras décadas do século XX, outros três álbuns com paisagens maranhenses de autores não identificados. O Maranhão Ilustrado ${ }^{5}$, de 1899/1900, é um deles. A semelhança no estilo fotográfico e alguns indícios históricos indicam a possibilidade de Gaudêncio Cunha ter sido o autor. Os outros, já localizados, são: o Album do Maranhão - Brasil, ao que tudo indica de $1904^{6}$ e o Album Commemorativo do $3^{\circ}$ Centenário de Fundação da Cidade de São Luiz, Capital do Estado do Maranhão, de $1913^{7}$.

Um olhar mais atento ao Album do Maranhão em 1908 identifica uma tensão entre a modernidade que o recém implantado regime republicano implementava no Brasil e antigas paisagens urbanas maranhenses que remontam aos tempos Imperial e Colonial. Essa contradição evoca dois questionamentos intercalados.

A primeira indagação diz respeito às finalidades pretendidas com a inclusão nas fotografias do álbum de 1908 de temas ligados à modernidade da época tais como fiação telefônica ou telegráfica, trilhos de bondes, ambientes internos voltados para o ens ino do saber técnico e indústrias. O segundo é intrigante por envolver situações mais complexas como a inclusão de cenários considerados antigos no início do século $\mathrm{XX}$ e algumas mudanças ocorridas no campo social.

O pouco que havia de moderno no Maranhão no início da República foi incluído no álbum de 1908, porque essa era uma necessidade da época. São conteúdos que aparecem unidos a um cenário maranhense que remonta ao Império e até mesmo a fase colonial.

É intrigante, por exemplo, a presença nas fotografias de ruas estreitas de São Luís, ladeadas por velhos casarões com beirais, pois esse tipo de paisagem estava sendo demolido em outras cidades brasileiras.

A imagem ambicionada e cobiçada pela recém criada república era a de um país conectado com um padrão urbano que vinha da Europa, sobretudo de Paris. O modelo vigente privilegiava largas avenidas com bulevares. Já estava sendo implantado em outras cidades do Brasil, como se verifica em alguns álbuns publicados nessa mesma época ${ }^{8}$. As transformações nessas cidades, como na Capital Federal, da época envolviam demolições e construções no

\footnotetext{
${ }^{4}$ O único exemplar que se conhece do Album Maranhão em 1908 pertence ao acervo do MHAM (Ver FONTES: Álbum 3).

${ }^{5}$ Ver FONTES E REFERÊNCIAS: Álbum 1

${ }^{6}$ Ver FONTES E REFERÊNCIAS: Álbum 2

${ }^{7}$ Ver FONTES E REFERÊNCIAS: Álbum 5

${ }^{8}$ Através do Dicionário Histórico-Fotográfico Brasileiro, Kossoy (2002) identifica fotógrafos que elaboraram álbuns com ícones da modernidade na mesma época, em outros estados. Esse assunto será abordado mais detalhadamente ainda neste capítulo.
} 
meio urbano, pois, expressas em forma de fotografias, na própria Exposição Nacional de 1908 no Rio de Janeiro 9 . Um dos trabalhos de maiores destaques foi o apresentado pelo fotógrafo Augusto Malta Campos (1864-1957) ${ }^{10}$.

Gaudêncio Cunha, ao incluir imagens de serviços públicos e privados modernos, ao lado de reminiscências do tempo do Império/Colônia encontrou uma maneira viável de atender a encomenda de seu cliente. Ele sabia que o mais importante era a necessidade de apresentar um Maranhão de perfil europeu, nacionalista e asséptico na exposição do Rio de Janeiro. O cliente tinha essa finalidade e o fotógrafo, quando selecionou o que seria fotografado, buscou atender, primordialmente a essa solicitação do contratante. Isso, contudo, não impediu que ele conduzisse o processo de seleção, influenciando as composições fotográficas com convicções e valores culturais próprios.

O cliente de Gaudêncio Cunha, o Estado do Maranhão, queria exibir uma imagem irretocável na exposição do Rio de Janeiro. Assemelha-se - guardadas as suas proporções - às pretensões de um cidadão de posses que encomendava o seu retrato com ares de autoridade e de boa posição social. O retratado, sempre sério, era associado a valores morais ${ }^{11}$, principalmente, se almejasse enviar a fotografia a um amigo ou parente distante.

Gaudêncio Cunha ajustou o que havia de elementos modernos com a paisagem urbana de São Luís disponível na época que era a remanescente do Império e da Colônia. Esse cenário, ele situou entre um ambiente de mata exuberante. $\mathrm{O}$ intuito assemelha-se ao desejo de apresentar uma civilidade de perfil europeu, erguida em um ambiente tropical, muito próximo do modelo de nacionalidade criado no tempo do Império de Dom Pedro II no século $\mathrm{XIX}^{12}$.

Do passado, houve interesse, também, em amenizar - em algumas fotografias aspectos sociais que lembravam o Império. Uma das imagens mais incômodas era a da escravidão. O trabalho livre, veloz e eficiente era mais apropriado ao novo Brasil Republicano. A imagem de homens brancos e negros da Companhia de Bombeiros (Fotografia 51), sentados juntos, com uniformes iguais tem exatamente o intento de acentuar uma eficiência que, para a historiadora da educação Diana Vidal ${ }^{13}$, era quase o sinônimo de sobrevivência, pois, para se manter na modernidade, o homem tinha que ser hábil e convincente.

\footnotetext{
${ }^{9}$ KOSSOY, Boris. Origens e expansão da fotografia no Brasil. Séculos XIX. Rio de Janeiro: MEC/FUNARTE, 1980, p. 78, 90 e 95.

${ }^{10}$ Ibid., p. 85.

${ }^{11}$ KOSSOY, Boris. Os tempos da fotografia: o efêmero e o perpétuo. Cotia: Ateliê Editorial, 2007. p. 43-44.

12 KOSSSOY, Boris. Fotografia e história 3. ed., São Paulo: Ateliê Editorial, 2003. p. 73-82.

13 VIDAL, Diana. Técnicas e sociedade no Brasil. São Paulo: Contexto, 1994, p. 63.
} 
O álbum de 1908, como qualquer outro documento histórico, não revela a própria sociedade do seu tempo, mas o que essa sociedade pensou de si. Para Vidal ${ }^{14}$, documentos históricos dos mais variados, como os utensílios, ferramentas e máquinas, são apenas pistas, indícios de uma época. Na visão da autora, “[...] mesmo que pudéssemos reconstruir todos os documentos escritos e não escritos como estátuas, túmulos etc., e "refazer" a sociedade não poderíamos encontrar o espírito mesmo dessa sociedade". Para a estudiosa, "os documentos não falam pela cultura que os produziu, mas podem nos indicar pistas sobre o modo como essa cultura encarava o mundo [...]"15. E é esse modo de olhar sua época que Gaudêncio Cunha traduziu no álbum de 1908.

\subsection{A modernidade aporta em São Luís}

A modernidade, na passagem do século XIX para o século XX, tinha na urbanização uma força substancial de expressão. A urbanidade começou a crescer no Brasil em meados do século XIX. De acordo com Caio Prado Junior ${ }^{16}$, nos fins do Regime Colonial, as cidades brasileiras ainda eram insignificantes. Rio de Janeiro, Cidade da Bahia, Recife e São Luís destacavam-se como as únicas que "fugiam à condição de aldeias".

A fotografia é um produto da modernidade e sua trajetória encontra-se ligada ao meio urbano que no Brasil cresceu a partir do século XIX, o que, de forma alguma significa a ausência de atividades fotográficas fora do meio urbano.

Embora hoje se saiba que as fotografias são construções a partir do real, no século XIX e início do século XX, essas imagens eram vistas como a tradução do real. Ao olhar uma fotografia, "o homem acreditava estar, sempre, diante da verdade"17.

As pessoas na passagem do século XIX para o século XX sentiam a necessidade de possuir imagens "iguais" ao mundo real. Aliado a esse anseio vinha o fetiche de guardar instantes de suas vidas e de entes queridos em forma de relicários, principalmente dos que estivessem distantes. Por fim, a fotografia amenizava a curiosidade de se conhecer outros lugares. "[...] Viajar por qualquer parte do mundo sem sair de casa [...]"18. E ainda saciava outros desejos como o de ter a posse da imagem de uma autoridade civil ou religiosa.

\footnotetext{
14 Ibid.

15 VIDAL, Diana. Técnica e sociedade no Brasil. São Paulo: Contexto, 1994. p. 23.

${ }^{16}$ PRADO JR, Caio. Evolução política do Brasil. São Paulo: Brasiliense, 2006, p. 22.

${ }^{17}$ KOSSOY, Boris. Os tempos da fotografia: o efêmero e o perpétuo. Cotia: Ateliê Editorial, 2007. p. 159.

${ }^{18}$ KOSSOY, Boris. Realidades e ficções na trama fotográfica. São Paulo: Ateliê Editorial, 2000. p. 65.
} 
Anteriormente, a pintura atendeu a alguns desses anseios, mas restringiu seu raio de ação a um número muito restrito de pessoas. A fotografia, apesar de ter sido em seu início acessível somente a um pequeno grupo de privilegiados, expandiu-se, se comparada à pintura. Os citadinos, que se consideravam afáveis, corteses e bem-educados eram os maiores consumidores.

Na São Luís de meados do século XIX e início do século XX, a fotografia e outros elementos da modernidade aportaram em navios. A ancoragem das embarcações ocorria em um porto localizado muito próximo da Avenida Maranhense, o local onde estava o centro de poder da cidade. Entre alfandegários e estivadores, os comerciantes -, importadores e exportadores - e os passageiros se envolviam em despedidas e traslados de mercadorias do porto para as embarcações ancoradas, através de embarcações menores. Tudo isso enchia a cidade de expectativas.

Os navios traziam as novidades modernas. Desembarcava na cidade o burburinho de centros urbanos como Lisboa, Rio de Janeiro e Paris. Desciam presentes e lembranças em forma de revistas, roupas, jornais e suas notícias e fotografias de autoridades. Em meios a mercadorias e idéias, chegaram a imprensa mecanizada, em 1866, o telégrafo terrestre em 1884, o maquinário das fábricas instaladas a partir de 1888 e o telefone, em 1890. O automóvel começou a circular pelas ruas de São Luís em 1903. Os fotógrafos viviam na expectativa da chegada de materiais fotográficos que estavam sempre sendo renovados.

Vivia-se um período iniciado na segunda metade do século XIX e anterior à Primeira Guerra Mundial, em que a tecnologia, filha pródiga da Revolução Industrial (iniciada na Inglaterra na segunda metade do século XVIII), passa a ocupar cada vez mais espaço na vida das pessoas. Esse tempo, remanescente do Renascimento e do Iluminismo, projetava o progresso como o remédio que curaria os males da humanidade. É comum chamar essa fase de Belle Époque e delimitá- la entre as décadas de 1890-1910. Foi nesse tempo que ocorreram as festividades em comemoração ao advento do século XX.

Balandier ${ }^{19}$ lembra que, antes da modernidade, o tempo presente se apoiava no passado; depois começou a recorrer à simulação do futuro. É mais ou menos nos interstícios desses dois momentos expressos por Balandier que se situa o Album do Maranhão em 1908.

Os tempos da modernidade envolviam o mundo de comportamentos acelerados e mutantes. Uma nova forma de viver expandia-se, respingando nervosamente mercadorias e comportamentos modernos nos confins da teia capitalista que se formava no planeta. É a

\footnotetext{
${ }^{19}$ BALANDIER, Georges. O poder em cena. Coimbra: Minerva, 1999.
} 
chegada do choque do mundo acelerado do qual nos fala Walter Benjamin ${ }^{20}$ em vários momentos de sua obra. O que se queira era sucumbir do tempo presente, a prevalência das experiências passadas, da memória, da exatidão, para, assim, tentar eliminá- las.

O mundo experimentava o alvorecer da era das incertezas. Os filhos, que anteriormente eram predestinados a seguir o ofício dos pais (filho de carpinteiro seria carpinteiro), passaram a ter mais um pouco de liberdade para escolher a profissão que queria seguir. No reinado do deus da improbabilidade, que invadia o Ocidente, a livre escolha e o progresso começavam a ditar as regras de convivência. O ser veloz se espalhava pelo mundo e aportava em São Luís quebrando a lentidão da cidade.

Algumas dessas novidades modernas foram recebidas com perplexidade em São Luís, como foi o caso do daguerreótipo. Mas, eram sempre bem-vindas, talvez por parecerem inevitáveis ou superiores ao cotidiano tranqüilo da capital maranhense.

São Luís foi uma das primeiras cidades do Brasil a ganhar ares de urbanidade no Brasil. No início do século XIX, encontrava-se entre as maiores cidades brasileiras, tendo cerca de 20 mil habitantes conforme estimativas de Caldeiras ${ }^{21}$. É o tempo áureo da econômica agro-exportadora maranhense centrada no Ciclo do Algodão que teve seu apogeu na passagem do século XVIII para o início do XIX ${ }^{22}$.

Um símbolo desse período de vigor econômico foi a inauguração do Teatro União em

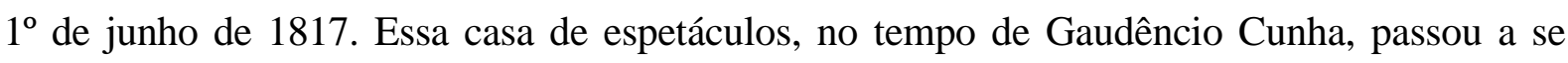
chamar Teatro São Luiz. Na década de 1840, a população de São Luís girava em torno de 25 mil habitantes, a maioria negra e mestiça ${ }^{23}$. O crescimento populacional deve ter sido

\footnotetext{
${ }^{20}$ Ver: BENJAMIN, Walter. Obras Escolhidas. São Paulo: Brasiliense, 1994. 3 vols.

${ }^{21}$ CALDEIRAS, Ribamar. O Maranhão na literatura dos viajantes do século XIX. São Luís: AML/SIOGE, 1991.

22 O Maranhão, até a primeira metade do século XXVIII apresentou pouco vigor econômico. Na segunda metade dos setecentos, a situação começou a se reverter por causa do ciclo do algodão. Esse plantio foi impulsionado pela criação da Companhia de Comércio do Grão Pará e Maranhão pelo Marques de Pombal. A Companhia funcionou de 1755 a 1777. Foi no ciclo do algodão que São Luís começou a crescer. Segundo Meireles, em 1760, saíram do Maranhão para Portugal as primeiras 6.510 arrobas de algodão. Em 1812 [...] as 217.754 de plumas, então exportadas, foram superadas quantitativamente pelas 354.646 de arroz [...] (Ver: MEIRELES, Mário. História do Maranhão. São Paulo: Siciliano, 2001, p. 44-45), o que representou, para o historiador Mário Meireles, o prenúncio do declínio do ciclo da cana-de-açúcar.

${ }^{23}$ Há divergências quanto a números populacionais do Maranhão e de São Luís em períodos do século XIX. Os historiadores do início do século XX, Ribeiro Amaral (AMARAL, José R. O Maranhão Histórico. São Luís: Geia, 2003, pg. 59-70) e Jerônimo Viveiros (VIVEIROS, Jerônimo. História do comércio do Maranhão 1612-1895. $1^{\circ}$ Volume. São Luís: Associação Comercial do Maranhão/Oficinas Gráficas do Jornal do Brasil, 1954, p. 285) reclamaram da falta de informações sobre quantitativos populacionais do Maranhão. O problema é mais grave, para Viveiros, na primeira metade do século XIX. Pelo censo de 1872 -, o primeiro a ser realizado no âmbito nacional -, população do Maranhão era de 359.940 e a de São Luís 31.664. Mesmo na obra de referência do geógrafo Fran Paxeco (PAXECO, Fran. Geografia do Maranhão. São Luís: Typogravura Texeira, 1922) há apenas repasse de dados do historiador José Amaral de que a população de São Luís era de 25 mil habitantes em 1836/37. (p. 19). Na pesquisa sobre divergências entre quantitativos
} 
gradativo ao longo da segunda metade do século XIX até chegar a 36.798, de acordo com o censo de 1900 e 52.920, segundo o censo de $1920^{24}$.

No apogeu do Ciclo do Algodão, São Luís ganhou ares urbanos. Hallewell ${ }^{25}$ informa que por volta de 1910 exportavam-se por essa cidade 500 mil toneladas de algodão por ano, o que fez de seu porto o quarto mais movimentado do Brasil, depois do Rio, Salvador e Recife. O Maranhão era a quarta região no comércio exportador e importador do Brasil, o que representava $11 \%$ do total, no período de 1796-1807, segundo Arruda ${ }^{26}$. Ficava atrás do Rio de Janeiro, Bahia e Pernambuco. De acordo com Caldeiras, nas primeiras décadas do século XIX, “[...] o Maranhão se incluía entre as mais ricas e importantes regiões do Brasil $[\ldots], 27$.

No século XIX, São Luís chegava a oferecer serviços de perfil urbano inexistentes em outras importantes cidades brasileiras. Os viajantes ligados a estudos botânicos, Luiz Agassiz (1807-1873) e Elizabeth Cary Agassiz, na visita de dois dias à cidade, em agosto de 1865, surpreenderam-se por encontrar um hotel na cidade. “[...] coisa surpreendente e digna de menção, o Maranhão possui um hotel: grande raridade numa cidade brasileira [...]"28.

No início do século XX, porém, com a gradativa decadência da economia agroexportadora maranhense ${ }^{29}$ e o início de uma transitória industrialização da economia maranhense, São Luís já se encontrava fora da lista dos maiores centros urbanos do país.

populacionais apresentados por viajantes que estiveram no Maranhão no século. XIX, o sociólogo Ribamar Caldeiras informa que Daniel Kidder disse que São Luís tinha 33 mil habitantes em 1841, enquanto George Gardner afirmou ser 26 mil para o mesmo ano. (CALDEIRA, 1991, p. 16-22). Todos os pesquisadores citados, porem, concordam em um ponto: a maioria da população era formada por negros, índios e mestiços. Um levantamento bibliográfico realizado pelo IPHAN em 2007 estabeleceu estimativas populacionais anteriores ao censo de 1872., o que inclui uma população de 25 mil habitantes, em São Luís, em 1845 e de 30 mil habitantes em 1868. Ver (CIDADES HISTORICAS. INVENTÁRIO E PESQUISA. SÂO LUİS. Rio de Janeiro: IPHAN/Senador Federal, p. 67-68).

${ }^{24}$ Os dados estão no relatório do VI Recenseamento Geral do Brasil 1950. Estado do Maranhão. Rio de Janeiro: Instituto Brasileiro de Geografia e Estatística - Conselho Nacional de Estatística. Série Regional, Volume XII, Tomo 1, 1955.

${ }^{25}$ HALLEWEEL, Laurence. O livro no Brasil. São Paulo: EDUSP, 1985, p. 93-110.

${ }^{26}$ ARRUDA, José J. A. A economia brasileira no fim da era colonial: a diversificação da produção, o ganho de monopólio e a falsa euforia do Maranhão. In: Revista de História. São Paulo: Serviços de Artes Gráficas/FFLCH/USP, 1989, p. 9-10.

27 1991, p. 12

${ }^{28}$ AGASSIZ, Luiz; AGASSIS, Elizabeth C. Viagem ao Brasil 1865-1866. São Paulo: Companhia Editora Nacional, 1938, p. 180.

${ }^{29}$ VIVEIROS, Jerônimo de. História do comércio do Maranhão. 1992, p. 1-30. 


\subsection{A Fotografia no século XIX e início do XX}

\subsubsection{Descobertas da fotografia}

As investigações no campo da História da Fotografia, no Brasil, apesar de algumas iniciativas isoladas como as de Sylvio Cunha e a de Gilberto Ferrez na década de $1940^{30}$, intensificaram-se na década de 1970. Foi nessa época que o historiador Boris Kossoy lançou suas primeiras teorias sobre o uso da fotografia como fonte da história cultural. Nesse tempo, ele também encontrou provas de um fato inusitado ocorrido em 1833 no Brasil: a descoberta de um método fotográfico no interior de São Paulo, desenvolvido por Hercules Florence (1804-1879). Isso, antes do anúncio oficial da descoberta do daguerreótipo ${ }^{31}$, na França, em 19 de agosto de $1839^{32}$.

O Francês Florence chegou ao Brasil em 1824; viveu a maior parte do tempo na Vila de São Carlos (atual Campinas - São Paulo) e morreu aos 75 anos sem ter o merecido reconhecimento $^{33}$. Mesmo depois da comprovação científica de sua descoberta, na década de 1970, Florence ainda continuou ignorado no Brasil, país onde ele vivera durante 55 anos. Ainda hoje, as referências a seu feito têm mais ressonância na Europa, notadamente na França.

De personalidade irrequieta, Florence realizou diversas atividades no campo da ciência e da pintura. Chegou até a participar da expedição científica que o Barão de Langsdorf

\footnotetext{
${ }^{30} \mathrm{KOSSOY}$, Boris. Os tempos da fotografia: o efêmero e o perpétuo. Cotia: Ateliê Editorial, 2007.

${ }^{31} \mathrm{O}$ daguerreótipo é uma invenção atribuída a Louis Jacques Mandé Daguerre (1787-1851) e Joseph Nicéphore Niépce (1765-1833). Segundo Kossoy (KOSSOY, Boris. Luzes e sobras da metrópole: um século de fotografias em São Paulo (1850-1950). In: PORTA, Paula. História da cidade de São Paulo. A Cidade no Império 1823-1889. São Paulo: Paz e Terra, 2004a, p.395), "consistia em uma placa de cobre recoberta de fina lâmina de prata, cuja superfície, extremamente polida, assemelhava-se a um espelho. Essa superfície era tornada sensível à luz através de vapores de iodo. Após a exposição na câmara, a placa era colocada em uma redoma onde recebia vapores de mercúrio, surgindo assim a imagem. A seguir a placa era fixada com hiposulfito de sódio e lavada em água. Surgia, assim a fotografia que não permitia a obtenção de cópia”. É o prime iro método fotográfico a prevalecer no mundo capitalista. Segundo Phelipe Dubois (2004), a sua descoberta resulta da conjunção de duas invenções preliminares e distintas, vistas pelo autor como "mitos fundadores" da fotografia: a 'natureza ótica' e a 'essencialmente química' (2004 p. 128 e 129). O daguerreótipo apresentava-se em, chapa de diferentes formatos e era montado em sofisticados estojos. Ver mais: KOSSOY, 2004b, p. 395; e KOSSOY, 1980, p. 25-33.

32 KOSSOY, Boris. Dicionário histórico-fotográfico br asileiro: fotógrafos e ofício da fotografia (1833-1910). São Paulo: Instituto Moreira Salles, 2002.p. 141-145.

33 KOSSOY, Boris. Hercules Florence 1833: a descoberta isolada da fotografia no Brasil. São Paulo: EDUSP, 2006.
} 
empreendeu pelos sertões de São Paulo, Mato Grosso e Grão-Pará entre 1825/1829, usando o transporte fluvial ${ }^{34}$.

Florence descobriu a técnica fotográfica quando passou a usar a luz do sol e a câmara escura para descobrir um método tipográfico mais barato e acessível, já que eram poucas as tipografias instaladas no País em sua época. A partir daí, ele conseguiu criar uma forma de impressão com características iguais a da fotografia, manipulando substâncias químicas fotossensíveis e solventes fixadores. Na época, ele reproduziu diplomas maçônicos, rótulos de farmácia etc. ${ }^{35}$. A experiência de Florence foi repetida e comprovada como viável por Kossoy, nos Estados Unidos, em agosto de $1976^{36}$.

A invenção elaborada por Florence ficou conhecida somente entre poucos amigos seus, enquanto o daguerreótipo disseminou-se pelo mundo, chegando logo ao Brasil. A primeira notícia sobre o daguerreótipo apareceu publicada no país no dia primeiro de maio de 1839, no Jornal do Commercio, do Rio de Janeiro ${ }^{37}$.

Em 1852, Florence relata como soube, em 1839, da descoberta do daguerreótipo. “[...] estava no campo, na morada de um amigo. Estava contente e conversando muito [...] ${ }^{, 38}$. Foi quando informaram a ele que saiu no Jornal do Commercio a notícia que em Paris achou-se um meio de fixar as imagens na câmara escura. "[...] Senti um choque no coração, no sangue, na medula dos ossos, em todo meu ser [...]"39.

As descobertas realizadas por Florence no Brasil e por Daguerre na Europa, por terem ocorrido em lugares distintos, aparentam desvinculações entre si. Só que os bons resultados obtidos por eles, as semelhanças entre as duas experiências e o período muito próximo em que eles a realizaram está longe de ser uma mera coincidência. Há causas comuns que levaram os dois fenômenos ocorrerem em uma mesma época, como diz Kossoy ${ }^{40}$.

Tanto o invento de Florence, como o daguerreótipo advém da conjunção de invenções e idéias que surgiram com a modernidade ou são anteriores a esse período e que encontraram condições de se confluírem em meados do século XIX. A própria modernidade resulta da soma de vários avanços científicos e filosóficos consolidados na Renascença, mas que já se

\footnotetext{
34 KOSSOY, Boris. Hercules Florence 1833: a descoberta isolada da fotografia no Brasil. 3.ed. São Paulo: Edusp, 2006. p. 52-66.

35 Ibid., p. 203-221.

${ }^{36}$ Ibid., p. 237-339

${ }^{37}$ Ibid., p. 129-134.

${ }^{38}$ Ibid., p. 397.

${ }^{39}$ KOSSOY, Boris. Origens e expansão da fotografia no Brasil. Século XIX. Rio de Janeiro: MEC/Funarte, 1980. p. 397.

${ }^{40}$ KOSSOY, Boris. Luzes e sombras da metrópole: um século de fotografias em São Paulo (1850-1950). In: PORTA, Paula. História da Cidade de São Paulo. A Cidade no Império 1823-1889. São Paulo: Paz e Terra, 2004a. v.2. 2004a, p. 226.
} 
manifestavam em momentos isolados, anteriores ${ }^{41}$. Em meados do século XIX, idéias e inventos da modernidade convergentes alicerçavam as condições favoráveis para o surgimento da fotografia. Por isso essa descoberta pode ocorrer em lugares distintos, como o Brasil e a Europa, mas em um mesmo período e onde transitaram idéias modernas.

Assim, a descoberta da fotografia em Campinas não decorre somente do esforço isolado de Florence. O daguerreótipo, também, não resultou apenas da soma de experimentos de cientistas europeus como Louis Jacques Mandé Daguerre (1787-1851) e Joseph Nicéphore Niépce (1765-1833).

A convergência de idéias e experimentos científicos que alicerçaram a descoberta da fotografia advém de avanços da modernidade que, segundo Koyré ${ }^{42}$, romperam com paradigmas em épocas diferentes e em sociedades distintas. Ele cita, por exemplo, a existência de embriões da modernidade até mesmo em ideais escolásticos criados por Santo Tomás e difundidos na Idade Média. Koyré apresenta o afloramento da modernidade como conseqüência da conjunção de várias idéias consolidadas a longo de séculos e não somente a partir de genialidades isoladas de dois ou três pensadores.

Dentro desse contexto, a fotografia é resultante de transformações que se consolidaram durante séculos e que encontrou condições para emergir em meados do século XIX em diferentes lugares. Considerando as idéias de Koyré é possível até mesmo afirmar que a fotografia é bem mais do que a conjunção de fórmulas óticas e químicas.

É possível dizer até que para criar métodos fotográficos, Florence e Daguirre/Niépce contaram - talvez até sem terem percebido - com a significativa colaboração de idéias Iluministas como as pesquisas do físico italiano Galileu Galilei (1564-1642) que resultaram na lei dos Corpos e no princípio da Inércia e o mundo da idéias de René Descartes (15961650). Todo esse conjunto de pensamento cooperou não só com o surgimento de invenções como a fotografia, mas, criou condições para o surgimento de sociedades propensas a acolher e consumir inventos como o daguerreótipo.

$\mathrm{O}$ daguerreótipo durou, mais ou menos uma década e meia ${ }^{43}$. $\mathrm{O}$ calótipo, do inglês Fox Talbot também é lançado no mercado nesse mesmo período. Apesar de apresentar mais viabilidade técnica que o daguerreótipo, pois permitia se tirar inúmeras cópias a partir de um só negativo, a sua difusão foi restrita se comparada à invenção francesa.

\footnotetext{
${ }^{41}$ KOYRÉ, Alexandre. Estudo de história do pensamento científico. São Paulo: Forense, 1991.

42 Ibid., p. 15-16.

${ }^{43}$ KOSSOY, Boris. Origens e expansão da fotografia no Brasil. Século XIX. Rio de Janeiro: MEC/Funarte, 1980. p. 14.
} 
A perda de espaço do calótipo para o daguerreótipo, segundo Kossoy ${ }^{44}$, aconteceu porque durante mais de uma década Talbot "funcionou como um verdadeiro fiscal de seu invento" ${ }^{, 45}$. Recorreu até aos tribunais para defender patentes. Enquanto isso, o daguerreótipo, doado ao mundo pelo Governo Francês, expandia-se. Em termos técnicos, o daguerreótipo tinha pelo menos uma vantagem com relação ao calótipo: apresentava mais nitidez, apesar de algumas dificuldades para se visualizar a imagem quando a luz incidia. O daguerreótipo também agregou vantagens no mercado, ao ser vendido em molduras e em caixas com tampas, como se fossem jóias preciosas.

O surgimento da fotografia é cercado de mitos. Manuais fotográficos e enciclopédias de curiosidades $^{46}$ lançadas no século XX envolvem essa descoberta nas mais inusitadas referências. Uma dessas histórias conta que Daguirre, depois de já ter conseguido transpor imagens para a placa polida, não conseguia fixá-las. Um dia, após um ensaio frustrado, ele arremessou a placa, cuja imagem começava a desaparecer, dentro do armário de seu laboratório. A placa, ao ser arremessada, teria derrubado alguns produtos químicos que, no escuro do armário, fixaram a imagem.

Em enciclopédias, há sempre especulações sobre a descoberta da fotografia na China em períodos anteriores ao nascimento de Cristo. Mas, no geral, tendem a enaltecer a contribuição de cientistas ocidentais para o advento da fotografia. Um exemplo é a invenção da fotoquímica pelo alemão Johann Heirich Schulze em 1727, e, evidentemente, as criações Nicéphore Niépce na primeira metade do século XIX.

\subsubsection{Daguerreótipo no Brasil}

Sem ressonância, a invenção da fotografia por Florence no Brasil entrou no ostracismo, enquanto o daguerreótipo encontrou condições favoráveis para preponderar no mercado capitalista mundial, incluindo o Brasil. Kossoy ${ }^{47}$ observou que a atividade fotográfica brasileira teve uma modesta expansão na fase do daguerreótipo, técnica que predominou no mercado brasileiro até o fim da década de 1850, aproximadamente.

\footnotetext{
${ }^{44}$ KOSSOY, op. cit., p. 35.

45 Ibid., p. 35.

46 Enciclopédia Barsa. São Paulo: Encyclopédia Britânica do Brasil Publicações LTDA, Volume 7, 1991; Enciclopédia Mirador Internacional. São Paulo: Encyclopédia Britânica do Brasil Publicações LTDA, Volume 9, 1977; NIEWENGLOWSKI, D.G.H. As Applicações da Photographia, Rio de Janeiro: Livraria Garnier, 1911; GRANDARD J. Manual do fotógrafo e cineasta amador. Lisboa: Livraria Bertrand, sem ano, entre outras.

${ }^{47}$ KOSSOY, Boris. Dicionário histórico-fotográfico brasileiro: fotógrafos e ofício da fotografia (1833-1910). São Paulo: Instituto Moreira Salles, 2002.
} 
Os historiadores da fotografia concordam que na fase do daguerreótipo foi considerável a presença no Brasil de fotógrafos originários do exterior. Eles eram, em sua maioria, anônimos comerciantes de serviços fotográficos que vieram para o Brasil, na avaliação do $\mathrm{Kossoy}^{48}$, devido a vários fatores, dentre os qua is se destaca a forte concorrência no mercado fotográfico de seus países de origem. Depois de reunir alguma renda com seu trabalho, eles retornavam aos seus países de origem. Os daguerreotipistas trabalharam principalmente, nos grandes centros urbanos situados na costa brasileira, como Recife e Salvador e, notadamente, no Rio de Janeiro.

O daguerreótipo aportou num país de dimensões continentais, administrado pelo regime Imperial de D. Pedro II. Na época, prevaleciam relações socioeconômicas que ainda evocavam traços dos tempos coloniais, sendo o trabalho escravo o mais visível e marcante. Condicionaram-se nesse ambiente, na opinião de Kossoy ${ }^{49}$, maneiras peculiares de expansão da atividade fotográfica. Para ele, nesse aspecto, o mais interessante é investigar "[...] a expectativa que tinham os homens das diferentes regiões e classes sociais em relação à fotografia $[\ldots]^{\prime, 50}$.

\subsubsection{Fotógrafos anônimos e o retrato brasileiro}

Tanto na fase do daguerreótipo, como em etapas seguintes em que novas técnicas fotográficas passaram a predominar no mercado, no século XIX e início do século XX, o serviço fotográfico mais difundido e vendido no Brasil foi o retrato. Novos processos fotográficos, alguns derivados do calótipo, aperfeiçoaram a técnica fotográfica. Duas dessas inovações são destacadas por $\operatorname{Kossoy}^{51}$ : o papel albumen que tornava a superfície lisa e eliminava a granulação e a técnica do negativo, a base de colódio úmido, usado desde a década de 1880. Os dois processos levaram praticamente ao abandono, do daguerreótipo e do negativo sobre o papel.

O número de fotógrafos cresceu na década de 1860, quando sistemas fotográficos, como o positivo/negativo ganharam mais evidência e substituíram daguerreótipo ${ }^{52}$. O retrato sobre papel fotográfico, em vários formatos, difundiu-se pelo mundo ${ }^{53}$. Outras técnicas

\footnotetext{
${ }^{48}$ KOSSOY, Boris. Fotografia e história. 3. ed, São Paulo: Ateliê Editorial, 2003.

${ }^{49}$ KOSSOY, Boris. Fotografia e história. 3. ed, São Paulo: Ateliê Editorial, 2003.

${ }^{50}$ Ibid., p. 143.

${ }^{51}$ KOSSOY, Boris. Origens e expansão da fotografia no Brasil. Século XIX. Rio de Janeiro: MEC/Funarte, 1980. p 35-38.

52 Ibid., p. 36-37.

${ }^{53}$ KOSSOY, Boris. Fotografia e história. 3. ed, São Paulo: Ateliê Editorial, 2003..
} 
garantiram o barateamento nos custos de produção, permitindo o acesso de um público maior aos serviços fotográficos. Kossoy ${ }^{54}$ exemplifica lembrando que um único daguerreótipo custava entre $5 \$ 500$ e $8 \$ 000$ na década de 1840 , baixando na década de 1870 para $3 \$ 000$ a dúzia, no formato carte de visite. O uso de papel como suporte, em substituição à placa cobre (e outros materiais), ajudou a diminuir os custos e ampliou o número de consumidores.

No campo da apresentação, a grande mvidade foi o carte de visite ${ }^{55}$ que surgiu na década de 1850. $\mathrm{O}$ invento consistia em um retrato colado sobre um cartão suporte de 5,25 x $10,2 \mathrm{~cm}$. Outros formatos maiores e menores também se tornaram conhecidos, embora menos consumidos $^{56}$. O carte de visite dinamizou a comercialização da fotografia pelo mundo, surgindo assim a necessidade do acondicionamento da fotografia. Foi então que apareceu uma nova moda: o uso de álbuns fotográficos de família ${ }^{57}$.

Autores de retratos, em sua maioria, era considerada artífice, como foram os marceneiros e pintores. Apesar de alguns fotógrafos do século XIX terem se destacado, principalmente os ligados à corte de Dom Pedro II, a maioria era formada por pessoas que dominavam os chamados ofícios liberais. Kossoy, por sua vez, os inclui na lista dos chamados fotógrafos anônimos ${ }^{58}$.

À medida que o século XX se aproximava, crescia o número de estabelecimentos fotográficos em virtude do maior número de fregueses que se formava nos centros urbanos. Eram profissionais como comerciantes, professores, funcionários públicos, entre outros. Borges $^{59}$ identifica esses lugares como "espaços por excelência da mudança social, da absorção das inovações tecnológicas, do comércio de mercadoria e das trocas simbólicas"60. Um território por onde transitou, segundo ela, a maioria dos fotógrafos estrangeiros e nacionais do século XIX.

Os retratos elaborados pelos fotógrafos anônimos, à primeira vista, são, esteticamente, parecidos entre si. Em geral, como observa Kossoy, os retratados apresentavam-se - ou exibiam seus filhos e entes queridos - com “"ar' de nobreza, através de trajes sempre elegantes no mais puro ar aristocrático da época" ${ }^{n}$.

\footnotetext{
${ }^{54}$ KOSSOY, Boris. Origens e expansão da fotografia no Brasil. Século XIX. Rio de Janeiro: MEC/Funarte, 1980. p.30.

${ }^{55} \mathrm{O}$ carte de visite é uma criação de André Adolphe Disdéri. Surgiu na França, em meados de 1850 (KOSSOY, 2004a, p. 396).

${ }^{56}$ KOSSOY, Boris. Origens e expansão da fotografia no Brasil. Século XIX. Rio de Janeiro: MEC/Funarte, 1980. p. 36.

57 Ibid.

${ }^{58}$ KOSSOY, Boris. Os tempos da fotografia: o efêmero e o perpétuo. Cotia: Ateliê Editorial, 2007. p. 66-77.

${ }^{59}$ BORGES, Maria Elisa L. História \& Fotografia, Belo Horizonte: Autêntica, 2005.

${ }^{60}$ Ibid., p. 106.

${ }^{61}$ KOSSOY, Boris. Fotografia e história. 3. ed, São Paulo: Ateliê Editorial, 2003. p. 109-110.
} 
Em 1862, na Europa, o mesmo fotógrafo que criou o carte de visite, publica um livro com princípios básicos de uma boa fotografia. O cliente tinha que apresentar aparência agradável, beleza, entre outros pré-requisitos ${ }^{62}$. Assim, o retrato passa a ser a expressão de inúmeros valores, incluindo os morais ${ }^{63}$.

A busca da beleza era um ideal exigido pelo cliente nos retratos que encomendavam aos fotógrafos. Gaudêncio Cunha, na passagem do século XIX para o século XX, vendeu retratos de alto padrão de qualidade aos seus clientes. Essa é uma das causas pelas quais ele conquistou a credibilidade do público de São Luís.

Através dos retratos de época, pesquisadores estão apreendendo o cotidiano dos brasileiros da segunda metade do século XIX e início do século XX. Eles identificaram preconceitos, afetuosidades, amores e outras emoções nos entremeios dessas imagens.

Um exemplo é Gilberto Freyre (1900-1987), que utilizou retratos de brasileiros do século XIX para mostrar a ocorrência de relações de afetividade entre brancos e negros, em meio à barbárie da escravidão. Essa mesma idéia, ele já vinha defendendo com veemência ao longo de sua atividade intelectual, mas utilizando somente fontes escritas ${ }^{64}$. Ao achado dessa particularidade em retratos de brasileiros do século XIX, ele chama de recorrências.

Os conteúdos dos retratos utilizados por Freyre apresentam crianças negras e brancas brincando e meninos brasileiros de ascendência européia postados carinhosamente ao lado de mulheres negras que trabalhavam como amas ${ }^{65}:$ '[...] não são raras as fotografias de meninos fidalgos dos tempos patriarcais, tendo ao lado malungos pretos ou pardos, como se fossem de todo seus irmãos. Os malungos iguais aos fidalgozinhos. E é possível, em alguns casos de fotografias dessa espécie, que os dois sejam verdadeiramente filhos do mesmo pai [...]”66.

O que Freyre (1983, p. 21) viu como recorrência em retratos de brasileiros do século XIX resulta exatamente de vivências culturais presentes em várias regiões do país. O problema é que Freyre prendeu-se ao argumento do senso comum de que as fotografias são exatas, "não mentem. Não inventam. Não fantasiam.". Enfatizou ser a fotografia um

\footnotetext{
${ }^{62}$ KOSSOY, Boris. Origens e expansão da fotografia no Brasil. Século XIX. Rio de Janeiro: MEC/Funarte, 1980. p. 30.

${ }^{63}$ KOSSOY, Boris. Os tempos da fotografia: o efêmero e o perpétuo. Cotia: Ateliê Editorial, 2007. p. 43-44, 50.

${ }^{64}$ Sobre relações de afetividade entre brancos e negros na obra de Gilberto Freyre ver: FREYRE, Gilberto. Casa grande \& senzala. 32 ed. Rio de Janeiro: Record, 1997.

${ }^{65}$ KOSSOY, Boris. Origens e expansão da fotografia no Brasil. Século XIX. Rio de Janeiro: MEC/Funarte, 1980. p. 45.

${ }^{66}$ FREYRE, Gilberto; PONCE DE LEON, Fernando; VASQUEZ, Pedro. O retrato brasileiro: fotografia da coleção Francisco Rodrigues, 1849-1920. Rio de Janeiro: FUNARTE/Fundação Joaquim Nabuco, 1983, p. 20.
} 
testemunho inconteste. Fez isso, talvez, somente para se defender dos adversários ferrenhos às suas interpretações sociológicas.

As relações de afetividade e violência entre brancos e negros no tempo da escravidão é um assunto complexo, especialmente quando se usa a fotografia como fonte histórica. Moreira Leite ${ }^{67}$, ao analisar retratos de famílias de imigrantes de 1890 a 1930 encontrou casos extremos de ambigüidade nas relações de solidariedade e intolerância ocorridas entre mulheres brancas e negras, principalmente nos casos em que escravas e agregadas sucediam às senhoras como parceira sexual ou eram alugadas como amas-de-leite.

A cultura escravocrata, longe de ser apenas uma formalidade abolida politicamente, ou uma estrutura própria dos ciclos econômicos, resistiu como mentalidade no cotidiano dos brasileiros depois de 1888, quando foi decretada oficialmente a abolição do trabalho escravo no Brasil e de outros acontecimentos políticos ${ }^{68}$, como a vigência do regime republicano em 1889. Algumas fotografias incluídas no Album do Maranhão de 1908, em que os mestiços e negros aparecem descalços nas portas dos armazéns lembram imagens do tempo da escravidão.

Há aspectos da cultura brasileira, como as relações de domínio entre brancos e negros no Brasil que parecem permanecer vivas mesmo depois da ilegalidade da escravidão. Por isso transparece em fotografias, independente da técnica utilizada e das alterações políticas ocorridas.

De acordo com Fernand Braudel ${ }^{69}$, as estruturas que resistem ao tempo, apesar de serem corroídas, de forma tênue, pelos interciclos da vida econômica e pelo tempo breve das relações políticas, de mentalidades de longa duração, ${ }^{70}$. A intercalação dos três tempos, para

\footnotetext{
${ }^{67}$ LEITE. Miriam M. Retrato de família. São Paulo: EDUSP/FAPESP 2001, p. 66-70.

${ }^{68}$ Vários autores encontram semelhanças entre a vida social dos descendentes de africanos antes e depois da abolição da escravatura. Ao comparar a situação da população negra recém saída da escravidão e os imigrantes europeus que se estabeleceram no Brasil, em grande escala na segunda metade do século XIX, Emília Viotti da Costa afirma: "[...] os escravos, marcados pelo legado da escravidão, não conseguiram, salvo raras exceções, competir com o estrangeiro no mercado de trabalho, e a maioria continuou como trabalhador de enxada, num estilo de vida semelhante ao de outrora". Ver: COSTA, Emília. Da Monarquia à República São Paulo, UNESP, 1999, p. 341.

${ }^{69}$ BRAUDEL, Fernand. História e ciências sociais. Lisboa: Presença, 1972.

${ }^{70}$ Fernand Braudel situa os acontecimentos históricos dentro de três tempos: curta duração (do tempo rápido e agitado do mundo político), de média duração (dos ciclos econômicos ritmando a evolução das sociedades) e o tempo lento, quase imóvel das estruturas construídas no meio sócio-cultural: a história das mentalidades. Entre os acontecimentos de longa duração estão os costumes e tradições que atravessam séculos quase imutáveis. As mentalidades de longa duração alojam-se nas instâncias políticas, religiosas, educacionais, na vida privada e mesmo nos contornos da paisagem urbana. Duração social (BRAUDEL, 1972, p. 10); o tempo breve ou a curta duração (BRAUDEL, 1972, p. 12-13, 19, 65, 101, 143); história dos ciclos econômicos (BRAUDEL, 1972, p. 17-18, 24-26, 43-44, 53-54, 81, 101-105, 155, 181); a idéia de mentalidades de longa duração (BRAUDEL, 1972, p. 60-83). Ver mais: REIS, José C Escolas dos Annales. São Paulo: Paz e terra, 2004, p. 15-35, 61, 81-85, 87 e 94.
} 
o autor, forma a história que é composta de temperaturas variadas, de ritmos diversos e de longevidades diferentes ${ }^{71}$.

\subsubsection{A paisagem fotográfica do século XIX}

Ao delinear características do circuito de produção, circulação e consumo da fotografia em São Paulo na segunda metade do século XIX, Solange Lima ${ }^{72}$ concordou com o parecer dos demais pesquisadores da história da fotografia brasileira, de que o retrato foi o serviço fotográfico mais vendido no século XIX e início do século $\mathrm{XX}^{73}$.

Apesar da venda de paisagens fotográficas não ser o principal filão comercial da fotografia no século XIX, a sua comercialização não foi insignificante, segundo os historiadores da fotografia ${ }^{74}$. O Album Comparativo da Cidade de São Paulo - 1862-1887 que Militão Augusto de Azevedo (1837-1905) produziu em 1887, é um exemplo de como a produção e comercialização de fotografia de paisagens foi relevante no século XIX. Outros fotógrafos se destacaram fazendo fotografias de paisagens nos oitocentos, entre eles Augusto Stahl (trabalhou no Brasil nas décadas de 1850 a 1870) e Marc Ferrez (1843-1928).

No caso específico do álbum de Militão, Kossoy ${ }^{75}$ acredita que uma das finalidades foi enaltecer as novas feições da cidade São Paulo, impulsionada pela produção cafeeira, em comparação à antiga cidade de feições coloniais. A busca dessa marca, que evidenciava o progresso e modernidade norteou outras produções pautadas na fotografia como é o caso do Album do Maranhão em 1908. Evidente que resguardando, dentro dessa generalização, as particularidades inerentes a cada caso.

Se por um lado Gilberto Freyre e Miriam Moreira Leite usaram retratos para espreitar os brasileiros dentro de suas moradias, estudiosos da história da fotografia como $\operatorname{Kossoy}^{76} \mathrm{e}$ a antropóloga Frehse ${ }^{77}$ sentiram curiosidade de saber como foi o cotidiano das pessoas nas ruas de São Paulo, por meio de produções fotografias de profissionais como Militão Azevedo.

\footnotetext{
${ }^{71}$ BRAUDEL, Fernand. Reflexões sobre a história. São Paulo: Martins Fontes, 2002. p. 373.

${ }^{72}$ LIMA, Solange F. O ciclo social da fotografia. Estudo de caso II. In: FABRIS, Annateresa. Fotografias: usos e funções no século XIX. São Paulo: EDUSP, 1998, p. 59-82.

${ }^{73}$ Ibid., p.61.

${ }^{74}$ Ibid., p. 66.

${ }^{75}$ KOSSOY, Boris. Militão Augusto Azevedo e a documentação fotográfica de São Paulo (1862-1887): recuperação da cena paulista através da fotografia São Paulo: FESP, 1988a.

${ }^{76}$ Ibid.

${ }^{77}$ FREHSE, Fraya. O tempo das ruas. São Paulo: Edusp, 2005.
} 
Kossoy mostra o cotidiano dos transeuntes e das celebrações cívicas no Largo do Palácio, Largo do Tesouro; o vai-e-vem de bondes, carroças e pessoas em ruas como a General Carneiro, Quinze de Novembro, Direita São Bento e São João ${ }^{78}$. Frehse, também, lançou um olhar interpretativo sobre os transeuntes paulistanos do século XIX que começaram a conviveram com a modernidade nas ruas.

Mas, que modernidade é essa? Qual a sua utilidade? Independente da necessidade de suas aplicações e de suas contradições, a modernidade passa a permear não só o cotidiano dos citadinos brasileiros, mas substancialmente a vida social e suas instituições, agora encravadas na urbanidade: as escolas, as empresas comerciais, os hospitais e os poderes constituídos.

Lembrando Walter Benjamim ${ }^{79}$, nos entremeios do conjunto de sua obra, é possível olhar na modernidade a presença de uma avalanche que atropela as experiências enraizadas. Transformações que avançam sem piedade sobre a memória, a tradição, a preservação. É o tempo em que o homem começa a ser treinado para o choque, para a mutação em seu cotidiano.

Segundo Benjamim, no século XIX “[...] surge uma série de inovações que tem uma coisa em comum: disparar uma série de processos complexos com um simples gesto [...]"80. Ele cita o exemplo do telefone, que da manivela, passou a funcionar somente com o gesto de tirá-lo do gancho e o click do fotógrafo que "[...] aplica ao instante um choque póstumo $[\ldots]^{\prime, 81}$.

Contudo, nesse mesmo mundo moderno, invadido por bondes, trens, telégrafos e telefones, velhas mentalidades, como os preconceitos aos negros no Brasil, resistem quase que indiferentes à aceleração do tempo. E essa contradição que aparece, de forma distanciada, em algumas composições fotografias presentes no Album do Maranhão em 1908.

Assim, entre os tempos curtos, médios e longos criados por Braudel arma-se uma complexa teia de imagens e relações em que o velho teima em resistir frente ao novo. Tal qual o poeta Charles Baudelaire, querendo ser lírico no auge do capitalismo ${ }^{82}$. Ele queria ser lido como um escritor da antiguidade ${ }^{83}$.

\footnotetext{
${ }^{78}$ KOSSOY, Boris. Imagens de Guilherme Gaensly. São Paulo: Kosmos, 1888b.

${ }^{79}$ BENJAMIN, Walter. Obras escolhidas III. Charles Baudelaire: um lírico no auge do capitalismo. São Paulo: Brasiliense, 1994.

${ }^{80}$ Ibid., p. 124.

81 Ibid.

82 Ibid.

${ }^{83}$ BRAUDEL, Fernand. História e ciências sociais. Lisboa: Presença, 1972. p. 88.
} 
Frehse $^{84}$ percebeu a tensão entre o velho e novo interferindo nas relações dos transeuntes das ruas da São Paulo dos oitocentos: '[...] é o velho brotando no âmago mesmo desse novo [...]". As ruas são historicamente, afirma Frehse ${ }^{85}$, "espaço freqüientado por grupos subalternos da sociedade, que ali forjam o seu dia-a-dia em termos socioeconômicos e culturais, sempre em torno das casas senhoriais". Mas é esse mesmo espaço que os senhores e as senhoras de melhor poder aquisitivo, também, começam a ocupar, atraídos pelas "atividades sociais modernas"

A autora observa, porém, que as elites paulistanas já ocupavam as ruas desde o período colonial em tempos de festas, sobretudo as religiosas, o que certamente ocorreu em outras cidades brasileiras, como São Luís. O que aconteceu ao final do século XIX é que grupos privilegiados da sociedade passam a sair às ruas com mais freqüência, atraídos pelas novidades de consumo e serviços de infra-estrutura urbana.

O comércio mundial de fotografias é dinamizado, principalmente na década de 1890 , com outro fenômeno: o da venda de cartões postais ${ }^{87}$. A moda não tardou a chegar ao Brasil. $\mathrm{O}$ ápice ocorreu m final da década e início do século XX, tempo em que Gaudêncio Cunha trabalhava em sua Photographia União, em São Luís. Assim, a hipótese de que esse fotógrafo aspirava a fotografar paisagens na semana de inauguração de seu ateliê, em agosto de 1895, ganhou relevo quando se soube que a comercialização de fotografias de paisagens já era uma atividade praticada, mundo afora, inclusive no Brasil.

É nesse clima da febre dos cartões-postais, que o fotógrafo Guilherme Gaensly (18431928) registra paisagens urbanas de Salvador e São Paulo. Suíço de nascimento, ele veio quando criança para o Brasil. Na capital paulista, registrou a expansão de uma cidade em que a burguesia industrial e comercial já era parte da paisagem das ruas. As imagens de paisagens de São Paulo feitas por Gaensly nos anos próximos à passagem do século XIX para o XX colaboraram na construção de uma imagem moderna da cidade ${ }^{88}$.

\footnotetext{
${ }^{84}$ FREHSE, Fraya. O tempo das ruas. São Paulo: Edusp, 2005.p. 84.

${ }^{85}$ Ibid., p. 30.

${ }^{86}$ Ibid., p. 97.

${ }^{87}$ KOSSOY, (2000, p. 64-7, 1980, p. 95-100).

${ }^{88}$ KOSSOY, Boris. Imagens de Guilherme Gaensly. São Paulo: Kosmos, 1888b. p. 74.
} 


\subsubsection{Fotógrafos famosos}

Entre os fotógrafos que trabalharam no Brasil do século XIX e início do século XX, alguns se destacaram em seu tempo, entre eles Marc Ferrez. Filho de um escultor francês que integrou a comitiva que acompanhou Dom João VI em sua vinda para o Brasil, Ferrez ficou conhecido por causa de suas relações com a corte e os retratos e paisagens no Rio de Janeiro. A sua obra, contudo, é bem mais ampla. Envolve registros de paisagens de construções modernas, imagens etnográficas e de paisagens de várias províncias brasileiras.

As fotografias de paisagens, porém, foram as que se evidenciam como a grande paixão na vida de Ferrez. Na visão de Burgi e de $\mathrm{Kohl}^{89}$, desde o início de sua carreira, Ferrez fez a opção de fotografar paisagens e vistas urbanas. Isso em “[...] oposição à maioria dos estúdios fotográficos comerciais do período que sobrevivia principalmente do retrato [...]" ${ }^{\prime 90}$. Essa predileção para os autores tem influência de parentes artistas de Ferrez, de estudos que ele realizou em Paris e da interação com outros fotógrafos de paisagens atuantes no Rio de Janeiro de seu tempo de jovem.

Outros fotógrafos do século XIX e início do século XX se destacaram em sua época e estão sendo privilegiados entre os pesquisadores. Entre eles estão os que conviveram com Ferrez na juventude: Victor Frond, R. H. Klumb, Augusto Sthal e G Leuzinger ${ }^{91}$. O alemão Albert Frisch criou retratos paisagísticos de índios românticos que lembram linguagens pictóricas; Christiano Júnior e Rodolpho Lindemann lançaram olhares para o mundo dos negros oitocentistas, Carlos César para a Guerra do Paraguai e Augusto Malta, para o Rio de Janeiro, e sem esquecer de Militão e Gaensly e a emergente São Paulo do café.

Os fotógrafos de paisagens do século XIX e início do XX demonstraram uma atração especial pelo moderno presente e circulante no meio urbano. Fotografaram trens e estradas de ferro, bondes, fábricas e as novas composições urbanas, com suas construções neoclássicas e largas avenidas. Na Amazônia, as fotografias de Felipe Augusto Fidanza são direcionadas para a modernidade expressa na urbanidade amazônica de Belém ${ }^{92}$ e de Manaus ${ }^{93}$.

Um detalhe que chamou a atenção desses fotógrafos foi o vai-e-vem de pessoas que iam às ruas não mais para estarem presentes em quermesses ou procissões, mas para comprar,

\footnotetext{
${ }^{89}$ BURGI, Sergio; KOHL, Stephan. O fotógrafo e seus contemporâneos: influência se confluências. In: O Brasil de Marc Ferrez. São Paulo: Instituto Moreira Salles, 2005.

90 Ibid., p. 66.

91 Ibid., p. 67.

92 PEREIRA, Rosa C. Paisagens urbanas: fotografia e modernidade na Cidade de Belém (1846-1908). Dissertação (Mestrado em História) - DEHIS -UFPA, Belém, 2006.

93 DAOU, Ana Maria. Memória e identidade social: o ‘Álbu m da cidade’ como representação da elite amazonense e da Manaus Antiga. In: Cadernos de Antropologia e Imagem. Rio de Janeiro, 1995.
} 
andar de bonde, serem fotografadas e olharem os lançamentos nas vitrines. Esse fenômeno fez Marc Ferrez voltar suas câmaras para o movimento frenético da Rua do Ouvidor ${ }^{94}$, no Rio de Janeiro e Guilherme Gaensly para a Rua de São Bento, em São Paulo ${ }^{95}$. O movimento frenético das ruas era uma das novidades modernas no Brasil da segunda metade do século XIX. Segundo Benjamin" ${ }^{96}$, a multidão metropolitana chegou a despertar "medo, repugnância e horror"97. A fotografia ajudava os olhos a se habituar a essa nova imagem.

\subsubsection{O Brasil nas imagens fotográficas}

No século XIX, fotógrafos famosos e anônimos criaram, também, as imagens etnográficas, que camuflavam em suas entranhas estereótipos de índios e de negros para, assim, serem vendidas na Europa. Foram elaboradas, também, em outros países do então Novo Mundo ${ }^{98}$. Nelas, os fotógrafos queriam apresentar os negros e os índios como tipos exóticos e diferenc iados dos brancos, visando atender aos desejos de consumidores europeus.

Há fotografias em que os personagens posaram vestidos com roupas típicas (ou exóticas) em ambientes de mata exuberante. Alguns usavam utensílios ${ }^{99}$ que, no imaginário da Europa moderna, eram considerados arcaicos se comparados aos deles. As imagens, na visão de $\operatorname{Kossoy}^{100}$, são idealizadas no ato fotográfico para atender às expectativas que os europeus pré-conceberam de índios e negros.

Os negros e índios estavam sempre descalços. Em algumas imagens, eles eram colocados próximos a instrumentos de medição de corpos para dar ares de cientificidade às imagens. "Vegetação exuberante e séries etnográficas dos grupos considerados como racialmente inferiores eram temas que os europeus esperavam ver quando se tratava de fotografia no Brasil, ou em outros países latino-americanos [...]"101.

O comportamento profissional dos fotógrafos autores dessas imagens é visto por Borges $^{102}$ como etnocêntrico. Nem todos ficaram famosos; muitos permaneceram no

\footnotetext{
${ }^{94}$ Ver fotografia no Álbum: O Brasil de Marc Ferrez. Vários autores, São Paulo: IMS: 2005.

95 KOSSOY, Boris. Imagens de Guilherme Gaensly. São Paulo: Kosmos, 1888b.

${ }^{96}$ BENJAMIN, Walter. Obras Escolhidas III. Charles Baudelaire: um lírico no auge do capitalismo. São Paulo: Brasiliense, 1994.

${ }^{97}$ Ibid., p. 124.

${ }^{98}$ KOSSOY, Boris. Fotografia e história. 3. ed, São Paulo: Ateliê Editorial, 2003.

99 A categoria utensílio é definida por Diana Vidal (1994) tudo aquilo que auxilia na realização de um trabalho ou qualquer atividade. É diferente de ferramenta que auxilia na feitura de objetos. 1002000.

${ }^{101}$ KOSSOY, Boris. Realidades e ficções na trama fotográfica São Paulo: Ateliê Editorial, 2000.p. 83.

${ }^{102}$ BORGES, Maria Eliza Linhares. História \& fotografia Belo Horizonte: Autêntica, 2005.
} 
anonimato. Luiz Humberto ${ }^{103}$ explica que nas fotografias etnográficas não havia espaço para imprevistos. "Intruso que se imiscui indelevelmente no negativo". O mais expressivo exemplo dessa fase é o Álbum Brasil Pitoresco, elaborado em 1858, pelo fotógrafo Victor Frond (1821-1881) e editado em 1861.

O trabalho do fotográfico alemão George Huebner sobre a Amazônia, como mostra Daniel Schoepf ${ }^{104}$ é um exemplo da precisão necessária para se elaborar as fotografias etnográficas e a valorização dessas imagens na Europa. A “[...] cada etapa, para cada sessão, é necessário forçar os índios a posar e, sobretudo, obrigá-los à imobilidade: colocar os modelos de tal forma que não movam [..."1105, relatou Huebner, conforme informação de Schoepf.

\subsubsection{Mestiços e negros no álbum de 1908 e nas fotografias etnográficas}

As representações de negros e índios nas fotografias etnográficas do século XIX, em alguns aspectos, são diferentes e até antagônicas às de mestiços e negros do Album do Maranhão em 1908. De início, vale lembrar que as etnográficas aqui citadas são do tempo do Império, quando o regime escravocrata era legal. Já as do Album do Maranhão em 1908 são do início da República, tempo em que a escravidão estava legalmente abolida.

Nas fotografias etnográficas do século XIX, os negros e índios estão em primeiro plano. Eles são os preferidos do foco. Por outro lado, no Álbum de Gaudêncio Cunha, os negros estão em segundo plano, às vezes quase imperceptíveis. Somente hoje, com o recurso da informática, é possível vê-los mais detalhadamente.

Apesar dos cenários apresentados nas fotografias etnográficas terem um perfil típico brasileiro, os negros e índios ali colocados parecem estar fora do seu lugar. A impressão é a de que eles foram mais do que convidados a estarem ali: teriam sido compelidos a posarem em uma paisagem cuidadosamente montada.

Nesse caso, os fotógrafos fizeram mais que uma mera seleção, eles elaboraram a cena e conduziram à posição dos figurantes. Burke identifica esse comportamento entre os fotógrafos ${ }^{106}$. Nas imagens etnográficas, as pessoas estão como que deslocadas em locais pretensamente naturais para eles. A paisagem em que estão não corresponde ao cotidiano em que eles viviam. Conseguia apenas atender ao ideário exótico de Brasil almejado na Europa.

\footnotetext{
${ }^{103}$ BORGES, Maria Eliza Linhares. História \& fotografia Belo Horizonte: Autêntica, 2005. p. 103.

104 Ibid.

105 SCHOEPF, Daniel. George Huebner 1862-1935, um fotógrafo em Manaus. Manaus e São Paulo: Metalivros, 2005, p. 26.

${ }^{106}$ BURKE, Peter. Testemunha ocular : história e imagem. Bauru: Edusc, 2004. p. 28.
} 
Isso se relaciona com o que Kossoy ${ }^{107}$ chama de "elementos de identificação do nacional do outro".

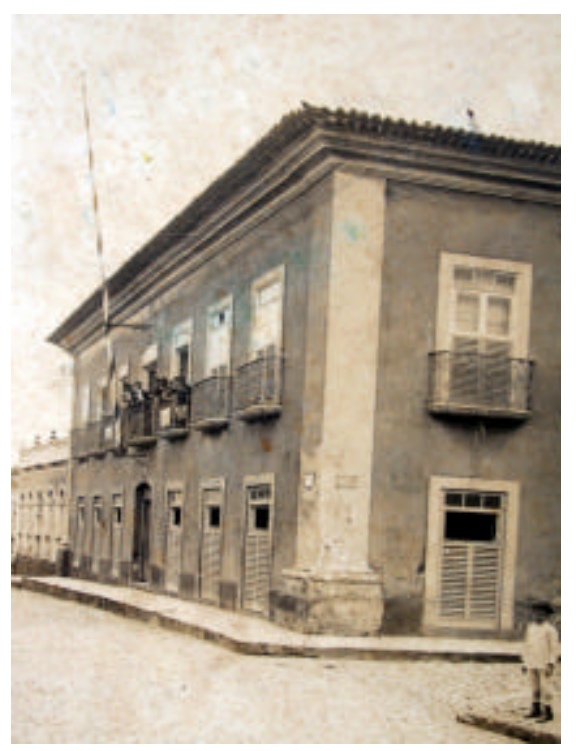

Fotografia 3 - Escola Normal. Album..., s.n.p., gelatina/prata, 18x13cm, MHAM.

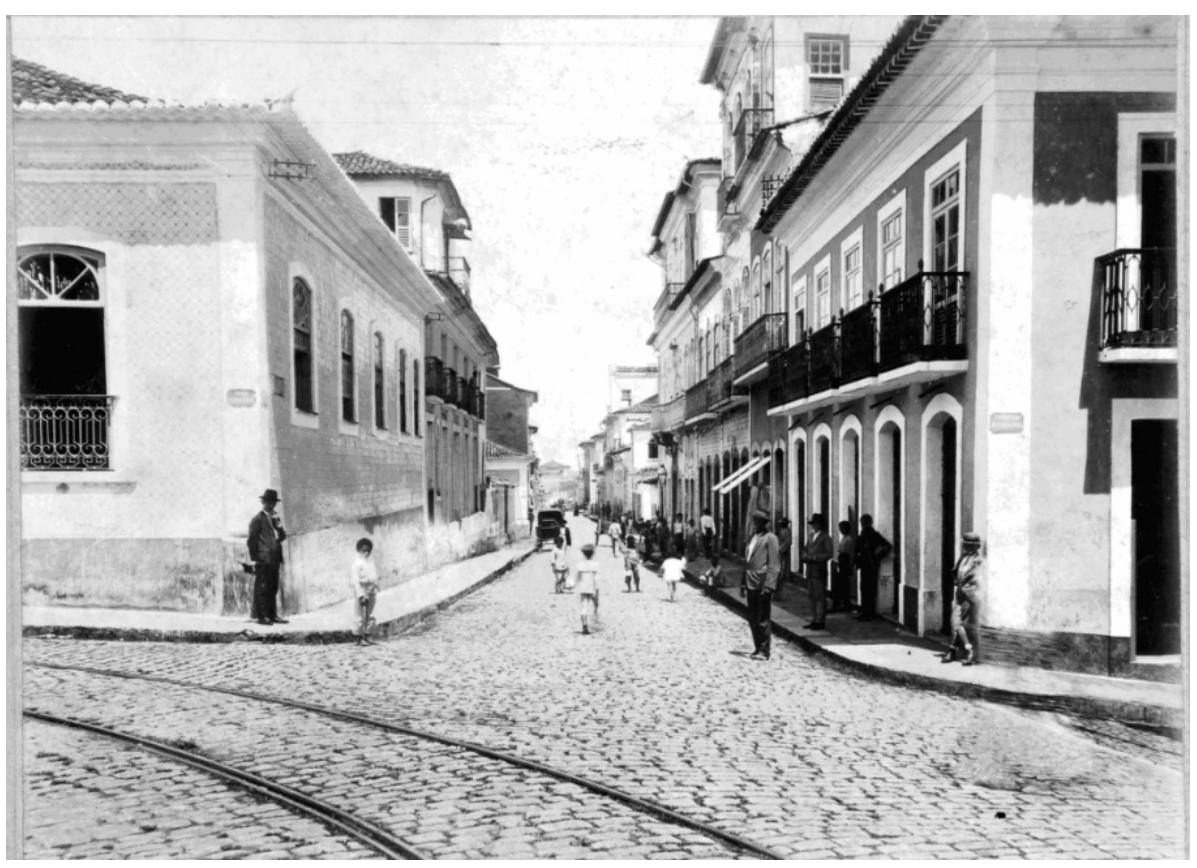

Fotografia 4 - Rua Afonso Pena. Album..., s.n.p., gelatina/prata, 15 x 20 cm, MHAM.

\footnotetext{
${ }^{107}$ KOSSOY, Boris. Realidades e ficções na trama fotográfica São Paulo: Ateliê Editorial, 2000.p. 83.
} 


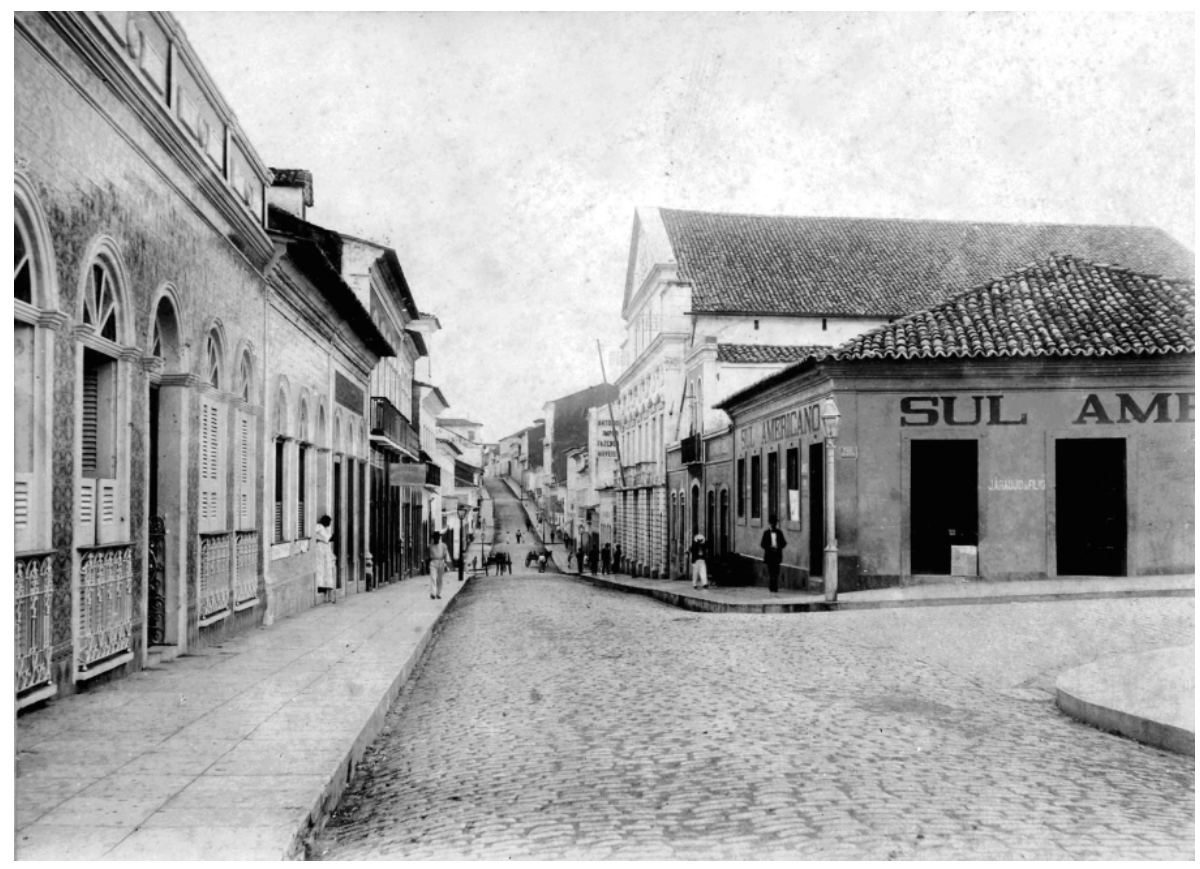

Fotografia 5 - Rua do Sol. Album..., s.n.p., gelatina/prata, 15 x 20 cm, MHAM.

Por outro lado, as pessoas presentes do Álbum maranhense estão no cenário em que vivia o seu dia-a-dia. Ali, eles eram habituais transeuntes. Aparecem lá, onde sempre estiveram. Olhando para a câmara ou não, eles integram o ambiente fotografado. Há momentos em que estão indiferentes ou dão impressão de que a normalidade alterou-se pelo ato fotográfico de Gaudêncio Cunha.

Na Rua Afonso Pena (Fotografia 4), enquanto pessoas estão posando ou observando o trabalho do fotógrafo, algumas crianças estão até de costas para a fotografia. Na Rua do Sol (Fotografia 5), a mulher na porta do imóvel nem olha para a câmara e um senhor na calçada está de cabeça baixa ajeitando o chapéu. Entre os garotos que estão nas sacadas da Escola Normal (Fotografia 3), alguns apresentam mais interesse em observar o trabalho do fotógrafo do que aparecer na fotografia.

\subsubsection{O Barão reage à imagem etnográfica}

As fotografias etnográficas foram idealizadas para serem vendidas a europeus e passaram a ser um incômodo para o Império Brasileiro do tempo de Dom Pedro II (18251891). Como contraponto, membros do Governo Imperial, tendo à frente o Barão do Rio Branco (1845-1912), promoveram a criação de uma nova imagem brasileira que valorizava 
dois ingredientes: civilização e natureza. O “[...] Estado monárquico era portador e impulsionador do projeto civilizatório e a natureza era a base territorial e material desse estado [...]"108.

Essa política do Governo Imperial ligou o Brasil à imagem de progresso, a um país que acompanha a modernidade redentora, industrializado e com o perfil social eminentemente europeu. Isso dentro de uma paisagem exuberante e paradisíaca. E foi justamente esse pensamento evocado pela administração de Dom Pedro II que se espalhou pelas províncias e se manteve até primeiras décadas da República, influenciando a concepção de álbuns fotográficos como Gaudêncio Cunha na elaboração do Álbum de 1908.

A construção de uma nova imagem para o Brasil no reinado de Dom Pedro II, nota Kossoy (2000, p.74-75), não ficou restrita às fotografias. Ressoou em setores da produção artística brasileira. Para isso, foram acrescentados diferentes ingredientes, além de civilização e natureza. As pinturas de Victor Meireles (1832-1903) e Pedro Américo (1843-1905) valeram-se também de feitos heróicos. Os escritores José de Alencar (1829-1877) e Gonçalves Dias (1823-1864) optaram por incluir no romantismo nacional a exaltação aos índios.

No campo da fotografia, a publicação mais relevante da idéia de civilidade brasileira é o Album de Vues du Brésil, idealizado pelo Barão do Rio Branco no ano da Proclamação da República. Reúne 24 imagens, a maioria de paisagens, produzidas por eminentes fotógrafos em atividade no Brasil do século XIX, entre eles Ferrez. Trata-se de uma evidente investida contra as fotografias etnográficas como as do Brasil exótico de Victor Frond.

Nesses períodos em que foram elaborados os álbuns de Frond e as idealizações do Barão do Rio Branco, expandiu-se, o número de fotógrafos em atividade no Brasil ${ }^{109}$. É consenso entre os historiadores que uma boa parte dos fotógrafos brasileiros do século XIX aprendeu o ofício trabalhando como auxiliares dos estrangeiros. Gaudêncio Cunha, muito provavelmente, foi aprendiz de ofício do português Felipe Augusto Fidanza que viveu em Belém na segunda metade do século XIX.

\footnotetext{
${ }^{108}$ KOSSOY, Boris. Realidades e ficções na trama fotográfica. São Paulo: Ateliê Editorial. 2000 p. 74

${ }^{109}$ KOSSOY, Boris. Dicionário histórico-fotográfico brasileiro: fotógrafos e ofício da fotografia (1833-1910). São Paulo: Instituto Moreira Salles, 2002.
} 


\section{CAPÍTULO II}

\section{O MARANHÃO DE GAUDÊNCIO CUNHA}

\subsection{Daguerreótipo aporta em São Luís}

O jovem dos Estados Unidos da América Charles DeForest Fredricks (18231894) foi o primeiro fotógrafo a aportar em São Luís. identifica-se como C. D Fredricks. Nos seguintes, adota o nome de Carlos no lugar de Charles, passando a ser Carlos D. Fredricks. O nome Charles não apareceu em nenhum anúncio. No período em que esteve no Maranhão, o seu sócio fez algumas viagens com o objetivo de intermediar a compra de material fotográfico.

As viagens de Charles Fredricks pela América Latina começaram quando ele tinha apenas $20 \operatorname{anos}^{1}$. Iniciou-se em 1943 na Venezuela, quando foi visitar um irmão (não se sabe se era o Alfred Fredricks) e decidiu empreender uma aventura por rios amazô nicos chegando até o Brasil. Retornou a New York e, depois, voltou ao Brasil quando passou por Belém, em 1846, São Luís, Recife e Salvador. Em 1848, foi a Buenos Aires e percorreu o interior da Argentina; em 1851, retorna ao Recife. Ainda visitou Rio de Janeiro e Porto Alegre. Em 1853, esteve em Paris onde assimilou novas técnicas fotográficas. Há a possibilidade de ele ter visitado outros países da América Latina. Depois de cerca de nove anos nessa itinerância, voltou para sua terra natal onde montou um bem sucedido estabelecimento fotográfico ${ }^{2}$.

No tempo que Fredricks esteve em São Luís e Alcântara, o Brasil ingressava nos anos iniciais do Segundo Império. O Maranhão de 1846 acabará de sair da sua maior insurreição popular: a Revolta dos Balaios ${ }^{3}$. Era uma época posterior à passagem de Luís

\footnotetext{
${ }^{1}$ KOSSOY, Boris. Os tempos da fotografia: o efêmero e o perpetuo. Cotia: Ateliê Editorial, 2007. p. 73-74.

${ }^{2}$ KOSSOY, Boris. Dicionário histórico-fotográfico brasileiro: fotógrafos e ofício da fotografia (1833-1910). São Paulo: Institut o Moreira Salles, 2002. p. 147-148.

3 A Revolta dos Balaios foi uma insurreição popular ocorrida entre dezembro de 1838 e janeiro de 1841. Começou no Maranhão e se estendeu pelo Piauí, com ressonância no Ceará, norte de Goiás e noroeste da Bahia. Há algumas versões sobre suas causas e desdobramentos. Ao que tudo indica o estopim aconteceu por causa de arbitrariedades judiciais contra vaqueiros do interior maranhense. Só que o pano de fundo gira em torno da grave situação econômica em que se encontrava a população do Meio-Norte Brasileiro, incluído parte da população branca e, principalmente, negros e mestiços. O escritor Domingos Gonçalves de Magalhães que acompanhou Luiz Alves de Lima e Silva na contenção dos rebeldes fez um relato sobre a revolta. (Ver: MAGALHÂES, Domingos J. G. Memória histórica e documentada da Revolução da província do Maranhão. São Paulo, Siciliano, 2001). No início do século XX, o jornalista Rodrigo Otávio escreveu sua versão da Balaiada (ver: OTÁVIO, Rodrigo. Depoimento de um dos heróis do cerco de Caxias sobre a Revolução dos Balaios. São Paulo, Siciliano, 2001). Ver, também: ARAÚJO, Maria R. História da Balaiada. São Luís, FUCMA/Arquivo Público do Maranhão, 2001; JANOTTI, Maria de L. M. A Balaiada. São Paulo, Brasiliense, 1991; ASSUNÇÃO, Matthias Röhig. Cabanos contra bem-te-vis: a construção da ordem pós-colonial no Maranhão - 18291841. in: PRIORE, Mary del e GOMES, Flávio dos Santos. Os senhores do rio Amazonas. Rio de Janeiro, Campus, 2003;
} 
Alves de Lima e Silva, o Duque de Caxias pela província. Ele foi enviado pela Coroa Brasileira para conter a revolta e governou o Maranhão entre 1840 e 1841 . A principal cidade, São Luís, tinha um pouco mais de 2.200 imóveis ${ }^{4}$.

Os fregueses de Fredricks em condições de pagar esse valor eram os brancos. Em geral, ocupantes de cargos públicos, comerciantes, religiosos, encarregados de gerenciar comércios e fazendeiros do interior que estivessem de passagem ou mantivesse residência em São Luís e Alcântara. A possibilidade de um escravo ter sido fotografado é remota. Talvez alguns tenham sido fotografados por Fredricks na condição de serviçal, como chegou a acontecer em outras localidades do País ao longo do século XIX ${ }^{5}$.

O jornalista, advogado e historiador João Francisco Lisboa (1812-1863), casado com a filha de um senhor rico de Alcântara, é um exemplo potencial de cliente de Fredricks. Colaborador do jornal Publicador Maranhense, Lisboa foi um duro crítico da sociedade da época e ainda alimentou polêmicas com intelectuais de seu tempo. É possível ter uma idéia das suas ironias no relato que faz sobre a presença de Gonçalves Dias na festa de Nossa Senhora dos Remédios, em São Luís, na década de 1850. “[...] Dando o braço a umas senhoras, conversando alegre e satisfeito, sem deixar rever o menor vislumbre daquela melancolia e desesperação que nos vende em seus mimosos versos [...]”6.

As fotografias, com o passar dos anos desbotam, perdem o brilho, amarelam e chegam até mesmo a ficar imperceptíveis aos olhos em alguns casos, inclusive as colorizadas no século XIX. Mas, o que transparecia no disse-me-disse na cidade era que as imagens desapareceriam por completo em um tempo breve.

Vale lembrar que na Europa, o daguerreótipo, qua ndo surgiu, também provocou reações adversas. Benjamin ${ }^{7}$ cita o exemplo do poeta Charles Baudelaire que encontrou na daguerreotipia "alguma coisa de provocante e assustador; "surpeendente e cruel",8

Apesar de informarem em setembro que pretendiam se retirar em breve, pois, o sortimento que trouxeram estava acabando ${ }^{9}$, a permanência deles se prolongou até o ano

TAVARES, Therezinha de J. A. A Revolta dos balaios no Maranhão (1838-1841). Dissertação (mestrado em história), Departamento de História da Universidade Federal Fluminense, Rio de Janeiro, 1982; (MEIRELES, 2001 p. 231-140); (PRADO JUNIOR, 2006 pg. 78-81) e (CALDEIRA, 1991 pg. 63-71).

4 Em 1838, São Luís tinha 2.213 imóveis, passando ter 2.429 em 1848. Ver: CIDADES HISTÓRICAS INVENTÁRIO E PESQUISAS. SÃO LUÍS. Rio de Janeiro: IPHAN/Senado Federal, 2007, p. 54.

${ }^{5}$ KOSSOY, Boris. Dicionário Histórico-fotográfico brasileiro: fotógrafos e ofícios da fotografia (1833-1910). São Paulo: Instituto Moreira Salles, 2002, p. 67; 1980, p.45.

${ }^{6}$ LISBOA, João F. A Festa de Nossa Senhora dos Remédios. São Luís: Editora Legenda, 1992, p. 51.

${ }^{7}$ BENJAMIN, Walter. Obras Escolhidas III. Charles Baudelaire: um lírico no auge do capitalismo. São Paulo: Brasiliense, 1994.

${ }^{8}$ Ibid., p.138.

${ }^{9}$ Publicador Maranhense, 02.09.1846. 
seguinte. $\mathrm{O}$ prazo inicial de partida era dezembro ${ }^{10}$. O anúncio da iminência de deixar a cidade pode ter sido uma estratégia de venda. Outros fotógrafos itinerantes que estiveram no Maranhão no decorrer do século XIX recorreram à tática semelhante.

Só que as vendas foram tão boas que em 21 de outubro, Carlos Fredricks convocou os clientes que haviam feito reserva antecipada para que se apresentassem até o dia $25^{11}$, pois havia recebido material fotográfico. Ele agradeceu a receptividade em um de seus longos anúncios:

[...] Como abaixo assingando tem feito sempre para estudar a melhor maneira de fazer a vontade aos seus beneméritos freguezes, e para executar a sua profissão como toda a beleza e fieldade, ele tem esperanças da continuação do liberal patrocínio, do qual elle já provas, e bastante ter recebido, e se roga ao ilustrado publico para que examinem os bellos retratos que elle agora esta tirando para segurança de igual continuação $[\ldots]^{12}$.

Fredricks anunciou em Recife que chegou a tirar "três mil retratos no Maranhão"13. Ele pode até ter estabelecido esse quantitativo somente como forma de sensibilizar o público pernambucano. Procedeu de maneira semelhante ao chegar a Salvador, onde afirmou ter feito quatro mil retratos em Pernambuco ${ }^{14}$. O certo é que o número de fotografias vendidas em São Luís e Alcântara foi alto, pois ele atendeu ao público durante cinco horas por dia (das 9 horas da manhã às 2 horas da tarde $)^{15}$ durante seis meses. Na capital maranhense, Fredricks não fez referência ao número de retratos que vendeu em Belém, a cidade em que esteve anteriormente.

Já mais próximo da partida, Carlos Fredricks ainda anuncia a sua pretensão de passar mais alguns dias na cidade, pois recebeu estoque de material fotográfico vindo de New York. Ele seguiu no início de fevereiro para Alcântara, outra importante cidade da província. Nesse mesmo mês, deu prosseguimento a sua viagem itinerante, podendo ter ido antes a New York $^{16}$.

Fredricks é um dos mais destacados fotógrafos itinerantes do século XIX. A sua trajetória no Brasil ainda é pouco pesquisada. Kossoy ${ }^{17}$ acredita que ele "[...] representa um dos mais interessantes exemplos da atividade desempenhada por um itinerante na América do

\footnotetext{
${ }^{10}$ Publicador Maranhense, 19.09.1846.

${ }^{11}$ Publicador Maranhense, 21.09.1846.

${ }^{12}$ Publicador Maranhense, 31.09.1846.

${ }^{13}$ KOSSOY, Boris. Dicionário histórico-fotográfico brasileiro: fotógrafos e ofício da fotografia (1833-1910). São Paulo: Instituto Moreira Salles, 2002. p. 147. 
Sul [...]". Mesmo assim, são poucas e superficiais as referências sobre a passagem por países do Sul da América.

Há perguntas intrigantes sobre a presença de Fredricks na América do Sul que ainda estão sem respostas. Como foi a viagem desse profissional pelos rios amazônicos? O que levou um jovem de 20 anos a empreender tal viagem? Como foi a receptividade à fotografia nas cidades latino-americanas por onde passou? Quais os amores desse jovem por essas cidades?

\subsection{Os fotógrafos itine rantes: a era dos retratos}

Carlos Fredricks não comercializou no Maranhão somente o daguerreótipo. Além de preparar retratos em alfinetes de peito e medalhões, vendeu prata brasileira e mexicana e pinturas de paisagens ${ }^{18}$. Os fotógrafos itinerantes e residentes que trabalharam no Maranhão depois de Fredricks, também, ofereciam outros serviços em seus estabelecimentos fotográficos. Podem ser considerados mestres de ofícios, pois estavam sempre ensinando alguma atividade profissional. Outros apresentavam espetáculos envolvendo a manipulação de inventos dos tempos modernos, atividade que os colocavam em situação semelhante a mágicos circenses.

Ao chegarem a São Luís, os fotógrafos itinerantes alugavam um imóvel no qual colocavam o seu negócio ou recebiam o abrigo de algum morador ilustre, incluindo desembargadores e comerciantes. Formavam sociedades comerciais entre si. Há casos em que um dos sócios viajava para comprar material fotográfico, ficando o outro trabalhando.

Em geral, eles faziam o primeiro anúncio comunicando a sua chegada na cidade. Colocavam o endereço e uma breve apresentação dos serviços oferecidos. Divulgavam de forma genérica, o nome do método fotográfico usado e o material como novidades que garantiriam a qualidade no serviço oferecido. Eles convidavam as pessoas a conhecer o processo fotográfico, sem compromisso de serem fotografadas.

Outra forma de chamar a atenção da freguesia era antecipando a data de partida. Na prática, o que terminava acontecendo era o prolongamento da permanência por causa das boas vendas. Houve momentos em que os clientes aguardavam para serem atendidos em posse de um "bilhete", pois faltava material fotográfico que vinha da Europa e dos Estados Unidos. Em geral, eles atendiam ao público das 8 ou 9 horas até às $14 \mathrm{~h}, 15 \mathrm{~h}$ ou $16 \mathrm{~h}$.

\footnotetext{
${ }^{18}$ Publicador Maranhense, 21.08.1846
} 
Mudavam o nome de seu serviço à proporção em que apresentavam nova tecnologia fotográfica. Anunciaram-se como ambrotypistas, ferotipistas entre outras denominações. Por motivos técnicos, faziam algumas recomendações, como o uso de roupas “pretas ou escuras”, como sugere o electrotypista Camilo Pinto da Fonseca Neves ${ }^{19}$.

Os fotógrafos itinerantes lembram imagens de caixeiros viajantes que vão de cidade em cidade apresentando novidades em comunidades isoladas. Remetem, ainda, a imagens estereotipadas de alquimistas e suas manipulações de produtos químicos e metais envolvidos em criações artísticas. Em artigo da edição do jornal Publicador Maranhense em $1856^{20}$, os alquimistas são citados entre os que contribuíram para a evolução da técnica fotográfica.

As atividades do itinerante Camilo Pinto da Fonseca Neves na São Luís da década de 1850 me levaram a pensar, no campo da segunda realidade, na passagem de ciganos pela pequena Macondo da literatura de Gabriel Garcia Marques, aldeia que ele idealizou encravada entre os confins da Amazônia Colombiana. Lá, os ciganos apresentaram as novidades modernas aos aldeãos, como o imã e o gelo, em forma de espetáculos ${ }^{21}$. Imagino a cena de Neves mostrando, nas horas vagas, espetáculos grátis, envolvendo os "[...] effeitos da ellectricidade $[\ldots]]^{, 22}$.

Os espetáculos envolvendo a apresentação de inovações modernas, as aulas de cunho profissionalizante e a venda de peças e serviços em ouro e outros metais, estavam entre os outros serviços oferecidos pelos fotógrafos itinerantes. Contudo, sua atividade comercial mais importante era mesmo a venda de retratos, assunto que se destacava nos anúncios de jornais.

Os retratos eram vendidos em preto e branco, às vezes depois de passarem por leves retoques. Alguns eram colorizados. Havia diversos serviços de molduras e de acabamentos que eles chamavam de caixinhas modernas ou caixinha de gosto moderno, caixilhos e quadros, principalmente quando se tratou de daguerreótipo. Medalhas, alfinetes de peito, entre outros recursos eram também usados como suporte.

Na segunda metade do século XIX, o retrato se transformou em um "fetiche" para os membros das famílias com maior poder aquisitivo, que se identificaram com a possibilidade real de conservar valores culturais congelados com ares de 'nobreza' e valores

\footnotetext{
${ }^{19}$ Publicador Maranhense, 20 de outubro de 1855.

${ }^{20} \mathrm{O}$ artigo é assinado por P. R. Corentin, identificado como engenheiro fotográfico e membro titular de várias academias científicas da França. Saiu no Publicador Maranhense de 16 de agosto de 1853, nº 1433, p. 1. VER: FONTES.

21 MÁRQUEZ, Gabriel. Cem anos de solidão. Rio de Janeiro: Sabiá/Vozes, 1972.

${ }^{22}$ Publicador Maranhense, 20 de outubro de 1855 e 02 de janeiro de 1857.
} 
morais, como observa Kossoy ${ }^{23}$. Os clientes gostavam dos retratos em que eles eram vistos como estilos 'aristocráticos'. Talvez para marcar espaço na sociedade brasileira que Freyre ${ }^{24}$ entende como antagônica em vários sentidos. “[...] Entre o grande proprietário e o pária. O bacharel e o analfabeto. $\mathrm{O}$ bandeirante e o senhor de engenho. $\mathrm{O}$ paulista e o emboada. $\mathrm{O}$ pernambucano e o mascate. Mas sobre todos os antagonismos, o mais geral e mais profundo: o senhor e o escravo $[\ldots]^{25}$

Os daguerreotipistas Gregório Antônio da Rocha Pereira e Justino Rocha Pereira estiveram em São Luís em períodos próximos, entre o final da década de 1850 e início da de 1860. O primeiro instalou seu ateliê localizado na Rua Grande, $89^{26}$ entre setembro de 1858 e 1859. O outro - que na opinião de Kossoy “[...] tem o perfil clássico do fotógrafo itinerante [...]"27 - esteve na cidade em junho de 1861. Apesar da semelhança dos nomes e da atividade profissional exercida é desconhecido qualquer tipo de parentesco ou relacionamento de amizade e sociedade entre os dois.

Alguns fotógrafos do século XIX eram pintores profissionais e exerceram a atividade fotográfica esporadicamente. No Maranhão, os pintores-fotógrafos são visíveis principalmente na década de 1860 , segundo Moraes $^{28}$. Eles pintavam paisagens e tiravam retratos. Domingos Tribuzi, Fortunato Ory, José Dumas e José Leon Righini são alguns que venderam serviços fotográficos em várias décadas do século XIX, mas como atividade complementar. Luiz Mello ${ }^{29}$, que mapeou as atividades de artistas que exerceram seus ofícios no Maranhão no período de 1842 a 1880, informa que José Dumas e Righini ofereceram serviços fotográficos na sociedade que mantiveram na Rua da Paz, $\mathrm{n}^{\circ} 7$.

O fotógrafo Higino Soares, que também era pintor ${ }^{30}$ anunciou suas atividades em meados da década de 1870 e início da de 1880. Soares era, sobretudo, um hábil comerciante que não media esforços para atrair seus fregueses. $\mathrm{O}$ aumento na concorrência e o processo de aperfeiçoamento das técnicas fotográficas fizeram os preços baixarem na década de $1870^{31}$.

À proporção que o século XX se aproximava, foram surgindo condições favoráveis para os fotógrafos fixarem residência nas cidades brasileiras. Os custos com

\footnotetext{
${ }^{23}$ KOSSOY, Boris. Os tempos da fotografia: o efêmero e o perpétuo. Cotia: Ateliê Editorial, 2007, p. 43-44.

${ }^{24}$ FREYRE, Gilberto. Casa grande \& senzala. 32 ed. Rio de Janeiro: Record, 1997.

${ }^{25}$ Ibid., p. 53.

${ }^{26}$ Publicador Maranhense 13.09.1858 e KOSSOY, 2002, p. 255.

${ }^{27}$ KOSSOY, Boris. Dicionário histórico-fotográfico brasileiro: fotógrafos e ofício da fotografia (1833-1910). São Paulo: Instituto Moreira Salles, 2002, p. 255.

${ }^{28}$ SARDINHA, 1997, p. 13.

${ }^{29}$ KOSSOY, Boris. Dicionário histórico-fotográfico brasileiro: fotógrafos e ofício da fotografia (1833-1910). São Paulo: Instituto Moreira Salles, 2002.

${ }^{30}$ MELO, Luiz. Cronologia das artes plásticas no Maranhão. (1842-1930). São Luís: Lithograf, 2004, p. 147.

${ }^{31}$ KOSSOY, Boris. Origens e expansão da fotografia no Brasil. Século XIX. Rio de Janeiro: MEC/Funarte, 1980 .p. 40 e 81-84.
} 
material fotográfico baixaram, garantido a oferta de serviços mais baratos. A boa condição para o fotógrafo fixar residência não fez os itinerantes desaparecerem, pois são visíveis até hoje pelo mundo afora.

Um dos mais hábeis fotógrafos itinerantes que esteve em São Luís foi C. Bischoff. Visitou outras cidades brasileiras. Foi até o Chile, onde faleceu em $1939^{32}$. Para Kossoy, a trajetória de Bischoff pelo Brasil ainda promete novas descobertas, pois ele passa a imagem de ter sido um andarilho compulsivo.

\subsection{Primeiras fotografias de paisagens maranhenses}

\subsubsection{A Revista do Norte}

Na década de 1890 e início do século XX, o fenômeno dos cartões-postais dinamizou o comércio fotográfico mundial e, conseqüentemente, o brasileiro. Vistas de cidades e da natureza passaram a ter mais valor, principalmente para serem usadas em correspondência e por colecionadores ${ }^{33}$. Os cartões-postais se espalharam pelo mundo desde a passagem do século XIX para o XX até a década de $1920^{34}$. A novidade, de modo algum, invalidou a venda de retratos, que permaneceu como filão indispensável no comércio fotográfico. Sem ser mais uma novidade, a fotografia assume o papel de serviço de consumo.

Nesse período, as impressões fotomecânicas ${ }^{35}$ favoreceram o surgimento de revistas ilustradas e álbuns impressos com imagens fotográficas e de gravuras ${ }^{36}$. As revistas ilustradas são lançadas no Brasil nas primeiras décadas do século $\mathrm{XX}^{37}$. As fotografias, em sua maioria, vinham sem crédito de autoria, apesar de alguns fotógrafos terem tido o privilégio de ter seus nomes incluídos, às vezes por "manobras", como a de gravar o nome no próprio negativo, como fez Augusto César Malta Campos (1864-1957) ${ }^{38}$

\footnotetext{
${ }^{32}$ KOSSOY, Boris. Os tempos da fotografia: o efêmero e o perpétuo. Cotia: Ateliê Editorial, 2007. p. 75.

${ }^{33}$ KOSSOY, Boris. Fotografia e história. 3. ed, São Paulo: Ateliê Editorial, 2003, p. 64-65.

${ }^{34}$ KOSSOY, Boris. Origens e expansão da fotografia no Brasil. Século XIX. Rio de Janeiro: MEC/Funarte, 1980, p.95.

35 KOSSOY, Boris. Dicionário histórico-fotográfico brasileiro: fotógrafos e ofício da fotografia (1833-1910). São Paulo: Instituto Moreira Salles, 2002, p.16.

${ }^{36}$ KOSSOY, Boris. Realidades e ficções na trama fotográfica. São Paulo: Ateliê Editorial, 2000, p. 64-67.

${ }^{37}$ KOSSOY, Boris. Origens e expansão da fotografia no Brasil. Século XIX. Rio de Janeiro: MEC/Funarte, 1980, p. 85.

${ }^{38}$ Ibid.
} 
Foi editada no Maranhão, no início do século XX, a Revista do Norte ${ }^{39}$, que publicou gravuras, retratos de celebridades, fotografias de paisagens e de eventos artísticos e religiosos. Publicou até mesmo informações factuais, como a visita do então vice-presidente da República, já eleito presidente, Afonso Pena ao Maranhão em julho de $1906^{40}$.

Há fotografias creditadas a Gaudêncio Cunha na Revista do Norte. As fotografias de paisagens de outros estados e países ganharam espaço privilegiado na Revista do Norte, ao que tudo indica porque satisfaziam o desejo das pessoas de conhecerem outros lugares.

\subsubsection{Fotógrafos de paisagem da década de 1890}

Na década de 1890, vários fotógrafos comercializaram fotografias de paisagens de São Luís. Até o momento, somente as imagens produzidas por Gaudêncio Cunha já foram localizadas e identificadas, integrando o álbum Maranhão Ilustrado ${ }^{41}$. São as fotografias mais antigas de paisagens maranhenses localizadas até agora.

O número de fotógrafos que trabalhou no Maranhão no século XIX e início do século XX ainda é incerto. No Dicionário histórico-fotográfico brasileiro: fotógrafos e ofício da fotografia $(1833-1910)^{42}$, há informações, também, sobre os trabalhos de João Evangelista Belfor (em 1861), Antônio José de Araújo Lima (em 1863), Theodoro Nadler (em 1863), Justino Nora (em 1868), José dos Reis Rayol, Jacques Vigier (períodos das décadas de 1860/1870), Antonio de Freitas Ribeiro (em 1868), Carlos Seidl (em 1863) e Baubrier (em 1880). Antônio José de Araújo Lima exerceu as funções de dentista e de fotógrafo em idos de 1863.

Em publicações localizadas no Arquivo de Obras Raras da Biblioteca Pública Benedito Leite (São Luís), foi possível identificar outros fotógrafos que trabalharam no Maranhão nas duas primeiras décadas do século XX. Há informações sobre Abdon Coelho, da Photographia Popular (talvez a mesma de Costa \& Sobrinho) no Album Commemorativo do $3^{o}$

\footnotetext{
${ }^{39}$ Com uma tiragem de seis mil exemplares, a Revista do Norte circulou de setembro de 1901 até agosto de 1906 (pelo menos). Inicialmente era publicação quinzenal, passando, em 1905, a ser mensal. O número de páginas podia variar entre oito e doze. Havia seqüências de numeração de uma publicação para outra, de modo que a paginação contém números superiores a 100. Havia suplementos, como o que presenteava os colecionadores com reprodução de gravuras. Havia colecionadores em outras unidades da federação, na Argentina, Europa e Estados Unidos. Era uma publicação ligada a Typogravura Teixeira (redação, administração e sala de leitura na Praça João Lisboa n. 4 - antigo Largo do Carmo; endereço telegraphico: Caixa Postal 40, telephone 56). Os editores eram Gaspar Teixeira \& Irmãos, Succs. e os editores Antônio Lobo e Alfredo Teixeira. Entre seus colaboradores estavam o médico Nina Rodrigues, o poeta Sousandrade e o teatrólogo Artur Azevedo e o escritor Graça Aranha. Há uma coleção da revista no Setor de Obras Raras da Biblioteca Pública Benedito Leite, em São Luís.

${ }^{40}$ Afonso Pena tomou posse do cargo de presidente da República em 15.11.1906

41 Ver FONTES E REFERËNCIAS Album 1.

${ }^{42}$ KOSSOY, Boris. Dicionário histórico-fotográfico brasileiro: fotógrafos e ofício da fotografia (1833-1910). São Paulo: Instituto Moreira Salles, 2002.
} 
Centenário de fundação de São Luiz, publicado em $1913^{43}$. O álbum tem textos e fotografias sobre a exposição do $3^{\circ}$ Centenário ocorrida no ano anterior na dependência do Palácio do Governo.

O jornalista fotográfico Dreyfus Nabor Azoubel (1919-2002) conta que o seu pai, Leão Menagem Azoubel (?-1951) trabalhou como retratista na segunda década do século $\mathrm{XX}^{44}$. Há, ainda, citações em jornais sobre trabalhos de Zadock Pastor, que atuou como fotógrafo em Caxias ${ }^{45}$.

\subsection{O fotógrafo Gaudêncio Cunha}

\subsubsection{O trabalho do retratista}

Na festa do dia 14 de outubro de 1909 na casa de número 30 da Rua do Sol, em São Luís, Gaudêncio Rodrigues da Cunha comemorou o seu aniversário cercado de familiares e amigos. Nesse dia, "na intimidade do Lar", como acentuara o Jornal dos Artistas ${ }^{46}$, ele vivia a certeza de ter conquistado uma posição de destaque e respeito dentro da sociedade maranhense. Isso, apesar de ter sentido os efeitos de baixas vendas em seus negócios por causa de intempéries econômicas vivenciadas no Maranhão, desde a sua chegada vindo de Belém do Pará. Há alguns anos trabalhando no ramo da fotografia, ficou conhecido em São Luís como um consagrado fotógrafo de paisagens e o retratista de importantes autoridades maranhenses.

Cunha vivia um momento bom em sua carreira. O Jornal dos Artistas lembrou da festa de seu aniversário com elogios a sua eficiência profissional. Gaudêncio Cunha e outro fotógrafo, Gregório Pantoja de Oliveira saíram juntos de Belém com a intenção de trabalhar no Maranhão. Chegaram entre o final da década de 1880 e meados da década seguinte. Os dois podem ter feito uma sociedade ou Pantoja apenas trabalhou em uma sociedade que Cunha abrira com o irmão.

Clodomir Braga Pantoja, filho de Gregório Pantoja, aponta ${ }^{47}$ o ano de 1888, como o de desembarque deles em São Luís; contudo, há contradições em seu depoimento. É mais

\footnotetext{
${ }^{43}$ Ver FONTES e REFERËNCIAS Álbum 5

${ }^{44}$ Entrevista concedida por Dreyfus Nabor Azoubel, 81 anos, ao lado de seu filho, o fotógrafo Uziel Azoubel, a José Reinaldo Castro Martins e o fotógrafo Edgar Rocha. Dia 11 de junho de 2001, em São Luís.

${ }^{45}$ Diário Oficial do Estado, 15.05.1900.

${ }^{46}$ Jornal dos Artistas, órgãos do Centro Artístico Operário Eleitoral Maranhense, 17.10.1909.

$47 \mathrm{O}$ depoimento foi concedido por Clodomir Pantoja em São Luís para técnicos integrantes do projeto "História da Fotografia no Maranhão (1850-1950)". O projeto foi idealizado pela museóloga Eliane Lili Vieira e o poeta José Valdelino Cécio Soares Dias (1952-2000) e coordenado pela socióloga Roseana Roedel Sena. Tem como base o convênio nº. $165 / 82$
} 
provável que eles tenham se instalado em São Luís entre o início e a metade da década de 1890. Clodomir Pantoja informa que, antes de deixar Belém definitivamente, o seu pai fez uma visita prévia a São Luís onde constatou as boas condições para montar um estabelecimento fotográfico. Depois, em uma segunda viagem, deixou o "velho Gaudêncio Cunha” em São Luís e "foi em Belém comprar máquina fotográfica e aparelhos para trabalhar em fotografia".

Segundo Clodomir Pantoja, o seu pai trabalhou na Photographia Fidanza, em Belém, onde Gaudêncio Cunha também deve ter iniciado suas atividades fotográficas. Interessante é que o Album do Maranhão em 1908 apresenta semelhanças históricas com Álbum do Amazonas 1901-1902. Nele, Fidanza mostra a reforma urbana iniciada em Manaus na década de $1990^{48}$. É muito provável que o trabalho de Fidanza, tanto em Manaus como em Belém, tenha influenciado e até servido de inspiração para Cunha.

O depoimento de Clodomir Pantoja coloca o seu pai na condição de comando de uma sociedade entre Gaudêncio Cunha e Gregório Pantoja, apesar de todos os indícios apontarem para uma situação inversa. Gaudêncio Cunha direcionava os rumos dos negócios quando os dois chegaram ao Maranhão. Cunha era mais velho do que Clodomir e foi ele quem decidiu permanecer em São Luís negociando a estada dos dois na cidade e enviou Gregório Pantoja para fazer a compra dos materiais fotográficos em Belém. Pantoja ou era um sócio comandado ou um ajudante.

A inauguração da Photographia União, em seu primeiro endereço, na Rua da Cruz, 47, aconteceu no dia 1 de setembro de $1895^{49}$, o primeiro domingo de setembro de 1895. Nessa fase, Pantoja e Cunha já deviam estar trabalhando em comércios separados, apesar de continuarem amigos. O convite, publicado em uma quinta-feira, agradece a boa acolhida dos maranhenses e convida o público para a inauguração:

Este Photographia acha-se montada em condições de poder realizar com maior presteza e asseio todos os trabalhos de arte preparando retratos de todos os tamanhos.... Montada como se acha a PHOTOGRAPHIA UNIÃO como todas as commodidades e decência, dispondo de MÁQUINAS DAS MAIS APERFEIÇOADAS espera merecer do público maranhense o acolhimento próprio

firmado em 1982 entre o Centro de Cultura Popular Domingos Vieira Filho (órgão da área de Cultura do Maranhão) e da então Fundação Nacional de Arte - Funarte (Governo Federal). Na entrevista, Clodomir Pantoja afirmara estar com 83 anos. O projeto teve a participação de profissionais do quadro funcional da área de cultura do Governo do Maranhão. Eles realizaram um levantamento de colecionadores e instituições que possuíam fotografias antigas e colhiam depoimentos em fitas cassete de fotógrafos e jornalistas de idade avançada. O material encontra-se sob a guarda do Centro Domingos Vieira Filho.

${ }^{48}$ DAOU, 1995.

${ }^{49}$ Federalista, 29.08.1895. 
da sua proverbial hospitalidade... Funcionará todos os dias das 8 da manhã às 5 da $\operatorname{tarde} \mathrm{e}^{50}$.

A base de sua renda durante suas atividades no Maranhão foi a venda de retratos e, depois de material fotográfico e de fotografias de paisagens. Funcionários do Governo, crianças, comerciantes, religiosos, empregados do comércio, indústrias e seus familiares foram retratados através dos serviços da Photographia União. Talvez até mesmo pessoas mais simples, como ex-escravos, podem ter feito suas economias com o objetivo de satisfazer o desejo de ter uma foto sua. Cunha nunca colocava o valor do trabalho nos anúncios de jornais. Diziam apenas que cobrava "preços módicos" 51.

É provável que ele ajustasse o preço do serviço de acordo com as condições e as necessidades de cada um. Isso, considerando determinados parâmetros tabelados que cobrissem os custos e garantissem um lucro para seu sustento, manutenção e expansão de seu negócio. A quantia média girava em torno de mil réis. Evidente que havia variações considerando o suporte utilizado, os acabamentos, a quantidade e o tamanho.

Os serviços fotográficos estavam cada vez mais acessíveis ao público. Eram bem diferentes dos altos valores cobrados na década de 1840, quando o daguerreótipo começou a ser comercializado no Brasil. Os avanços tecnológicos ajudaram no barateamento do material e dos produtos fotográficos e, conseqüentemente, na fixação de preços mais baixos.

Entre as autoridades, retratadas por Cunha está o bispo Dom Antônio Xisto Albano (1859-?). O religioso foi retratado oito dias depois de desembarcar em São Luís para assumir a direção da Igreja Católica ${ }^{52}$. Entre vários compromissos políticos e administrativos, o bispo encontrou tempo para ir até a casa de Gaudêncio Cunha, "retratar-se, satisfazendo assim o pedido que lhe foi feito", como informa o Diário do Maranhão ${ }^{53}$. A decisão do bispo demonstra o destaque profissional que Gaudêncio Cunha conquistou no Maranhão.

Coincidentemente, há um retrato - sem crédito do fotógrafo - de Dom Xisto na Revista do Norte de $1^{\circ}$ de setembro desse mesmo ano, juntamente na edição em que as fotografias da recepção pública ao bispo foram publicadas ${ }^{54}$. Só que o retrato é de autoria do dinamarquês Niels Olsen (1843-1911) que trabalhou desde a década de 1880 em Fortaleza ou

\footnotetext{
${ }^{50}$ Jornal Federalista, 29.08.1895.

${ }^{51}$ Federalista, 29.08.1895.

${ }^{52}$ Nascido em agosto 1859, Dom Xisto estava próximo de completar 42 anos. Ele desembarcou em São Luís no dia 3 de julho de 1901 e tomou posse no cargo dois dias depois. Ficou no cargo até 14 de dezembro de 1905. Ver Diário do Maranhão dos dias 4, 5 e 6.7.1901 e PACEHCO, Felipe C. História eclesiástica do Maranhão. São Luís: Departamento de Cultura do Maranhão/Gráfica Luz, 1968, p. 465-482.

${ }^{53}$ Diário do Maranhão, 11.7.1901.

${ }^{54}$ A Revista do Norte publicou 4 fotografias da recepção pública ao bispo, sem créditos fotográficos. Uma é a do desembarque do religioso. Há uma segunda da recepção nas proximidades do Palácio do Bispo e de sua passagem pela Rua do Sol, exatamente na altura em que se encontra a Photographia União.
} 
de um dos seus filhos que continuaram tocando os negócios depois de sua morte ${ }^{55}$. Um original desse retrato encontrado em São Luís comprova a autoria ${ }^{56}$. Outro retrato Dom Xisto foi localizado - uma reprodução impressa -, mas não há autoria ${ }^{57}$.

A presença de celebridades locais nos encontros sociais realizados na Photographia União demonstra a credibilidade que Gaudêncio Cunha conquistou entre as elites e setores médios do Maranhão desde que veio de Belém. Dois fatores colaboram para o seu êxito. Um é o padrão dos serviços oferecidos pela Photographia União, principalmente a nitidez dos retratos e paisagens, uma exigência de padrão de qualidade na época.

Pesou, também, o fato de Gaudêncio Cunha ter optado por uma vida de certa forma introspectiva. Apesar de manter boas relações dentro da sociedade, há indícios de que ele tinha algumas reservas, principalmente no que se refere a sua vida particular. Reforça a idéia de que era voltado para dentro de si. Em São Luís, ele criou a imagem de homem trabalhador e bom amigo. De sua vida particular, sabe-se que adotou um filho.

A sua vida pessoal estava adequada aos padrões sociais da época, necessários para consagrá-lo como o profissional escolhido para retratar autoridades e elaborar álbuns de paisagens maranhenses como o que foi enviado a exposições nacional e internacional realizadas na época no Rio de Janeiro e em Paris.

\subsubsection{Viagens, prêmios, álbuns e exposições}

A Photographia União mudou-se para a Rua do Sol, em novembro de $1899^{58}$. O novo endereço tinha uma localização bem mais privilegiada. Ficava mais próximo do Teatro São Luís, da Praça João Lisboa (antigo Largo do Carmo) e do Largo do Palácio, os dois mais importantes logradouro da cidade. No novo ateliê, ele fotografou importantes autoridades e elaborou o Album do Maranhão em 1908. Clodomir Pantoja improvisou um resumo sobre a localização do comércio de Cunha na Rua do Sol: "Tem o lado do teatro, mais em cima, quase de canto com a Rua da Cruz" ${ }^{59}$.

\footnotetext{
${ }^{55}$ KOSSOY, Boris. Dicionário histórico-fotográfico brasileiro: fotógrafos e ofício da fotografia (1833-1910). São Paulo: Instituto Moreira Salles, 2002. p. 244-246.

${ }^{56}$ Há uma cópia desse retrato do bispo na biblioteca do Museu de Artes Visuais (Anexo do Museu Histórico e Artístico do Maranhão, em São Luís), com a autoria. No verso da fotografia, foi escrita em caneta a data de 16.6.1901. A chapa original deve ter sido guardada no ateliê dos Olsen na capital cearense.

${ }^{57}$ PACHECO, Fellipe C. História eclesiástica do Maranhão. São Luís: Departamento de Cultura do Maranhão/Gráfica Lux, 1968.

${ }^{58}$ Regeneração, n. 380, 21.11.1899.

${ }^{59}$ Depoimento de Clodomir Pantoja já citado.
} 
unha dedicou-se com afinco para transformar a Photographia União num estabelecimento reconhecido pelo bom atendimento e pela qualidade dos serviços oferecidos. A Revista do Norte lembrou desse aspecto. "O proprietário d'este estabelecimento, não tem poupado esforços para conseguir elevá-lo ao mais alto grau de conceito, tendo sido honrado pelas ilustradas redacções da imprensa maranhense, merecendo ser classificado um dos primeiros do Norte da República" ${ }^{, 60}$.

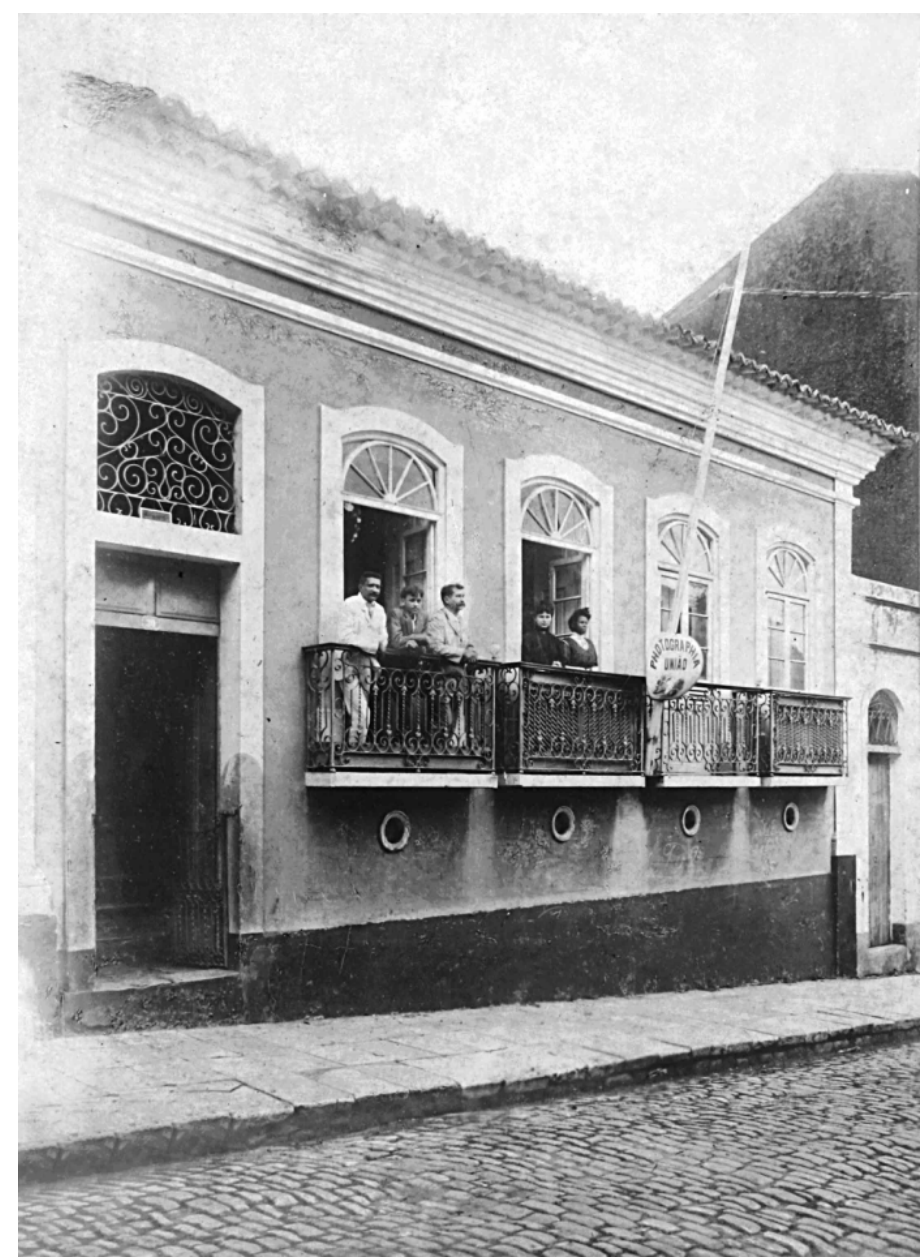

Fotografia 10 - Fachada da Photographia União, na Rua do Sol, 30. Álbum..., s.n.p., gelatina/prata, 22,5 x 17cm. MHAM.

\footnotetext{
${ }^{60}$ Revista do Norte, 16.9.1901.
} 


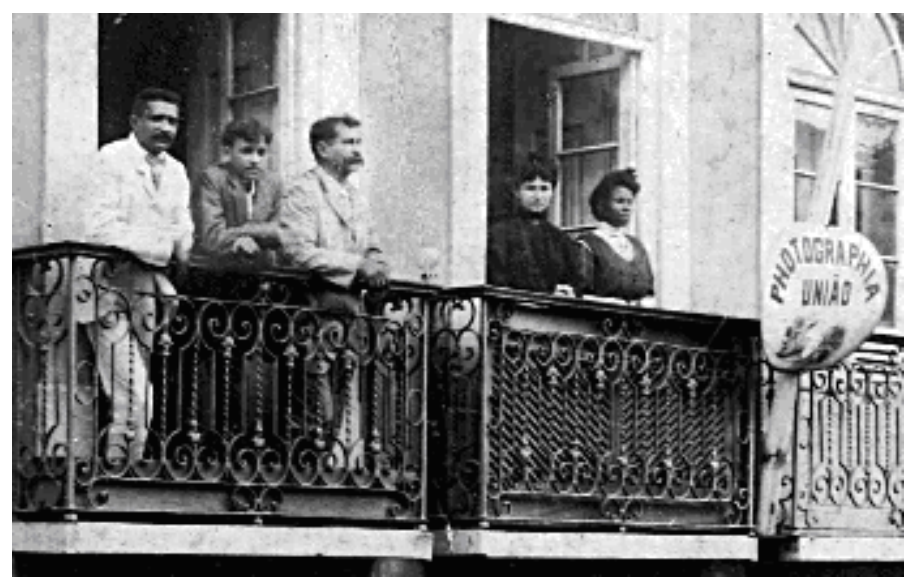

Ilustração 3 - Pessoas nas sacadas da fachada do imóvel da Photographia União na Rua do Sol, 30. Detalhe da Fotografia 10.

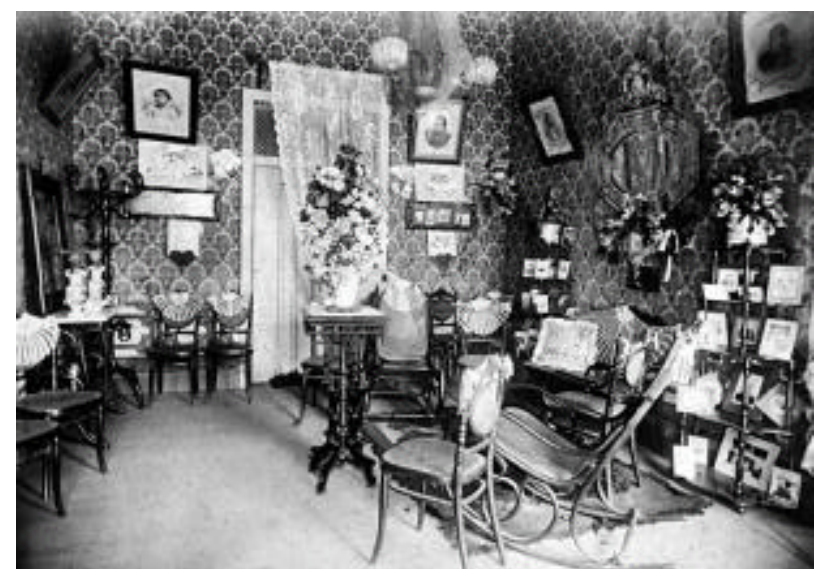

Fotografia 11 - Ambiente interno da Photographia União. Sala de Espera. Álbum..., s.n.p., gelatina/prata, 15 x $20 \mathrm{~cm}$. MHAM.

Apesar do sucesso que alcançou em sua trajetória profissional no Maranhão, Gaudêncio Cunha enfrentou diversos problemas para manter o seu negócio, o que o levou a realizar viagens pelo interior do Maranhão e Piauí e diversificar seus negócios elaborando álbuns.

Os jornais chamam o álbum de 1899/1900 de Album do Maranhão. Só que o localizado nessa época tem o nome de Maranhão Ilustrado ${ }^{61}$. O que tem o nome de Album do Maranhão que foi localizado não tem data e nem autor ${ }^{62}$. Moraes ${ }^{63}$ indica que o Album do Maranhão localizado seja do ano de 1904, o que é muito provável. As fotografias incluídas nas duas obras localizadas têm semelhanças estéticas com as elaboradas para o álbum de 1908, mas não há comprovação sobre a autoria das duas publicações.

\footnotetext{
${ }^{61}$ Ver FONTES E REFERÊNCIAS Álbum 1

${ }^{62}$ Ver FONTES E REFERÊNCIAS Álbum 2.

${ }^{63}$ ABRANCHES, 1993, p. 82.
} 
Um volume intitulado "Album do Maranhão", ficou em exposição no escritório do Sr. Adolfo B. Nogueira, (Rua 28 de julho n. 15) em 1900 ${ }^{64}$. Em maio de 1908, a Editora Gaspar Teixeira \& Irmãos vendia edições de um álbum com fotografias coloridas de ruas e praças de São Luís. Esse, provavelmente, é o Album do Maranhão, já localizado ${ }^{65}$. Uma edição estava sendo vendida por seis mil réis; "Está um trabalho perfeito e acabado, impresso em optimo papel, e recommenda-se principalmente pela nitidez das vistas e encadernação do volume" $"$, anuncia o jornal. Só que o álbum com o nome Album do Maranhão em 1908 localizado tem um número de fotografias superior a $12^{67}$.

Seguindo uma tendência da época, a sociedade maranhense organizou diversas exposições locais na segunda metade do século XIX e no início do Século XX. Gaudêncio Cunha participou de algumas.

A exposição de maior destaque foi realizada em 1912, em comemoração aos 300 anos de fundação de São Luís pelos franceses. Como resultado da festa foi publicado, no ano seguinte, um álbum ${ }^{68}$ com fotografias de profissionais não identificados. Como na época havia vários fotógrafos na cidade, inclusive amadores, há incertezas quanto à autoria das fotografias.

Gaudêncio Cunha está incluído na lista de premiados na exposição de 1912, por quadros de fotografias e oito cartões postais que integraram a Seção de Artes Liberaes ${ }^{69}$. Outros fotógrafos participaram como expositores. Abdon Coelho expôs e foi visto fotografando o evento, inclusive a presença de grupos visitantes, como o liderado pelo governador Luiz Domingues ${ }^{70}$.

A Photographia União e Gaudêncio Cunha devem ter recebido outros prêmios de instituições maranhenses. Homenagens a artistas e celebridades eram comuns nesse tempo. Serviam para sustentar o movimento da sociedade da época. Cunha ganhou, em $1906^{71}$, um prêmio em exposição organizada pela Festa Popular do Trabalho ${ }^{72}$, uma instituição respeitada na época. Ajudou, inclusive a organizar a exposição de 1912. Cunha utilizava esses eventos mais como estratégia de divulgação dos seus serviços. Ele sabia da importância dessas relações para a manutenção de seus negócios.

\footnotetext{
${ }^{64}$ Regeneração 27.1.1900.

65 Ver FONTES E REFERÊNCIAS Álbum 2

${ }^{66}$ O Maranhão, 1.5.1908.

${ }^{67}$ Ver FONTES E REFERÊNCIAS Álbum 2

${ }^{68}$ Ver FONTES E REFERÊNCIAS Álbum 5

${ }^{69}$ Incluído no texto do Album commemorativo do $3^{\circ}$ Centenário de Fundação da Cidade de São Luiz, Capital do Estado do Maranhão, p.42 e 47. Ver: FONTES E REFERÊNCIAS, Álbum 5.

${ }^{70}$ Ver FONTES E REFERÊNCIAS, Álbum 5

${ }^{71}$ A exposição foi realizada em maio de 1906. Diário do Maranhão, 2.5.1906.

${ }^{72}$ Diário do Maranhão, 29.5.1906.
} 
Independente do trabalho com paisagens, a Photographia União manteve a venda de retratos fotográficos. Usava como estratégia para atrair clientes o anúncio sobre a compra de novos equipamentos, renovação de estoques e a redução de preços. "[...] Para esse bem montado estabelecimento acaba de ser despachado o papel platinotipia, o melhor e mais usado em toda a Europa [...]"73.

A Photographia União expandiu seus negócios a ponto de se transformar em local de revenda de materiais para fotógrafos amadores ${ }^{74}$. Gaudêncio Cunha era preocupado em atualizar os equipamentos e renovava freqüentemente o material fotográfico. "Em correspondência direta com os primeiros fabricantes da Europa e da América, tem a Photographia União aperfeiçoado aparelhos e todo material relativo" aunciou em várias edições da Revista do Norte.

Gaudêncio Cunha, no tempo dessa crise econômica, deve ter enfrentado outros dois problemas e é 'provável eu tenha falecido por volta da segunda emtade do século $\mathrm{XX}$. Em 1900, o Maranhão contava com 499.308 habitantes dos quais 36.798 em São Luís. Apesar da epidemia da peste bubônica de 1903 em São Luís, a população saltou para 874,337 no Maranhão e foi para 52.929 em São Luís, em 1920 ${ }^{75}$. Em 1918, segundo dados apurados por Fran Paxeco, São Luís tinha 32.592 habitantes ${ }^{76}$.

\subsection{O Maranhão na Exposição Nacional de 1908}

O Maranhão se mobilizou desde os primeiros meses de 1908 para participar da Exposição Nacional, marcada para ser aberta no dia 15 de junho, na praia do Rio Vermelho, na Capital Federal. O álbum de 1908 foi uma das peças de maior relevância enviadas pelos maranhenses. Mas outros objetos foram elaborados especialmente para serem enviados para o evento.

O Governo do Maranhão, intendências municipais, escolas, empresas comerciais, fábricas e pessoas individualmente se movimentaram com o objetivo de viabilizar suas participações. Senhoras de destaque na sociedade e mestres de ofícios elaboraram as mais diversas peças. Inicialmente, o material foi enviado para a Repartição de Obras Públicas, Viação, Indústria, Terras e Colonização, órgão do Governo do Maranhão, localizado à Rua da Estrela, 70, em São Luís. Esse setor governamental selecionava e classificava as peças que

\footnotetext{
${ }^{73}$ Pacotilha, 9.5.1903.

${ }^{74}$ Edições da Revista do Norte de 1901 e 1902.

75 1950, p. 1; 1974, p. 20.

76 1922, p. 21.
} 
seriam enviadas para a avaliação da Comissão Superior da exposição, na Capital da República $[\ldots]^{77}$.

Para participar, era necessário preencher o que eles chamavam de Boletim de Inscripção. O comissário do governo maranhense na exposição, Domingos de Castro Perdigão teve a preocupação de divulgar nos meses antecedentes ao dia de abertura, o nome das pessoas e instituições que enviavam peças e os regulamentos da Exposição que àm, gradativamente, sendo expedidos no Rio de Janeiro.

Para Silva Filho ${ }^{78}$, Perdigão não foi escolhido à toa pelo governador para ser comissário. O governador levou em conta o reconhecimento pelo trabalho que ele realizara frente à reorganização da Sociedade Festa Popular do Trabalho, através da qual ajudou a organizar exposições locais e a participação maranhense em exposições internacionais.

Perdigão demonstrou particular cuidado com o acondicionamento dos objetos. A recomendação é que as tampas dos caixões fossem fechadas com parafusos para facilitar a abertura e a "[...] re-expedição dos productos [...]"79. O Governo do Maranhão gastou pelo menos oito mil réis só no pagamento dos operários que trabalharam no preparo de caixões e no encaixotamento dos objetos ${ }^{80}$

Oficialmente, a exposição de 1908 no Rio de Janeiro comemorou os 100 anos da Abertura dos Portos do Brasil para as Nações Amigas, por Dom João VI. Só que no governo do prefeito Francisco Pereira Passos (1836-1903), entre 1902 e 1906, parte da paisagem urbana da Capital Federal se adequou aos padrões considerados modernos na época. No lugar de ruas estreitas foram erguidas largas avenidas. Uma das causas motivadoras da montagem da exposição teria sido a necessidade de dar visibilidade a esse novo Rio de Janeiro como cartão-postal do Brasil. Evidentemente, a meta visível da exposição era a de mostrar a produção brasileira nos seus mais variados modos.

O prefeito Pereira Passos, na sua gestão, transformou a paisagem urbana do Rio de Janeiro, principalmente na sua área central. Ele colocou em prática medidas consideradas "higienizantes" com a retirada de quiosques de madeira e telhado de zinco que estavam espalhados pelas vias públicas. "Nada havia de mais anti-higiênico à beleza e à estética" afirmou Austregésilo de Athaide, anos depois, em apoio a remoção das pequenas vendas das vias da capital brasileira.

\footnotetext{
${ }^{77}$ Diário Oficial , 02.4.1908.

78 2006, p. 29-30.

${ }^{79}$ Diário Oficial do Maranhão, 2.4.1908.

${ }^{80}$ Diário Oficial do Maranhão, 15.4.1908.

${ }^{81}$ ATHAYDE, Raimundo A. Pereira Passos. O reformador do Rio de Janeiro. Rio de janeiro: Editora A note, 1941.
} 
Mas, o alargamento de vias da área central da cidade, como a Rua Acre e a Avenida Rio Branco foi o que mais chamou a atenção. "Rasgou-se em pleno coração da metrópole, a grande artérea que é a Avenida Rio Branco"82, enalteceu Athayde. A Exposição Nacional de 1908 foi o primeiro grande evento organizado pelo poder público no Rio de Janeiro, depois que o prefeito Pereira Passos alterou a paisagem urbana da cidade.

A urbanidade moderna da Capital Federal atraiu a atenção dos maranhenses presentes na exposição. Eles trouxeram cartões postais dos pavilhões da exposição ${ }^{83}$ e das avenidas e prédios no estilo neoclássico da área modernizada da Capital Federal. O material encontra-se no Museu de Artes Visuais do Maranhão. O mesmo deve ter acontecido com participantes de outros estados. Tudo indica que a área do Rio de Janeiro modernizada no início do século XX inspirou transformações urbanas realizadas em outras cidades brasileiras.

O Governo do Brasil foi o principal responsável pela organização da Exposição Nacional. No acervo do Museu de Artes Visuais do Maranhão há retratos, em forma de cartão-postal, do ministro da Indústria e Viação, Miguel Calmon e do presidente do Directorio Executivo da Exposição Nacional, Antonio Olyntho dos Santos Pires, produzidos pela Casa Standard (Rua do Ouvidor, 72, Rio).

Todos os estados instituídos na época participaram. Um cartão-postal ${ }^{84}$ com a fotografia do pavilhão Palácio dos Estados inclui a lista com o nome dos 20 estados e do Distrito Federal. São eles: Amazonas, Pará, Maranhão, Piauhy, Rio Grande do Norte, Parahyba, Pernambuco, Alagoas, Sergipe, Bahia, Espírito Santo, Estado do Rio, São Paulo, Santa Catarina, Paraná, Rio Grande do Sul, Goiaz, Mato Grosso, Minas e Rio de Janeiro.

Cerca de dois mil operários trabalharam na montagem da Exposição. Em fevereiro, os organizadores informam que a construção dos prédios dos pavilhões e praças estava adiantada ${ }^{85}$. Paralelo ao andamento das obras, o Directorio Executivo instituiu vários regulamentos que normalizavam o acesso dos visitantes, os critérios para participar e as premiações.

O Regulamento Especial das Entradas da Exposição estabeleceu a cobrança de $2 \$$ (dois mil réis) por pessoa no dia da inauguração. Nos demais dias, o preço seria determinado

\footnotetext{
${ }^{82}$ Ibid, p. 300.

${ }^{83}$ Há 25 cartões postais da exposição produzidos pela Companhia Lith Hartmann Reichenbach. Neles encontram as seguintes legendas: vista geral, porta monumental vista de dentro da exposição para fora, fonte luminosa, Recinto das Diversões, Restaurante Pão de Assucar, Esplanada do Baluarte, Palácio de São Paulo, Palácio do Distrito Federal, Caes do Urca onde são queimados os fogos, Pavilhão dos Bombeiros, Annexo do Pavilhão de Portugal, Palácio Manoelino (exposição de Portugal), Palácio da Bahia, Palácio de Minas Gerais, Palácio da Sociedade Nacional de Agricultura, Pavilhão dos Correiros e Telegraphos, Theatro de Exposição, Palácio das Indústrias, Palácio dos Estados, Ponte das Barcas, Avenida dos Estados, Matas, Jardins, Caça e Pesca, Pavilhão Egypcio, Pavilhão da Fabrica Tecidos "Bangu” e Restaurante Rústico.

${ }^{84}$ Há um no Museu de Artes Visuais do Maranhão

${ }^{85}$ Diário Oficial do Maranhão, 5.2.1908.
} 
entre os limites $\$ 500 \$$ (500 réis) e $2 \$ 000$ (dois mil réis). As horas franqueadas deviam ser publicadas nos jornais ou fixadas na véspera [...] no recinto da exposição $[\ldots]^{86}$. Outros dois países participaram: Portugal e Egypto.

Com a experiência profissional, Gaudêncio Cunha reuniu as melhores fotografias de paisagens maranhenses que tinha e fez sua obra de excelência especialmente para a exposição. O Album do Maranhão em 1908 representou o Maranhão juntamente com outras peças elaboradas por pessoas e instituições de destaque na sociedade maranhense. É provável que vários objetos enviados para a Repartição de Obras Públicas podem nem ter seguido para o Rio de Janeiro.

O governador Benedito Pereira Leite encaminhou, em fevereiro, mensagem para o Congresso Legislativo do Maranhão sancionando uma lei que autorizava o Governo arcar com as despesas necessárias para que o Maranhão participasse da exposição. Opositores de Benedito Leite, segundo Silva Filho ${ }^{87}$, criticaram o governador, pois consideraram que ele deu apoio excessivo aos participantes da exposição. “[...] comprehendidas as que disem respeito à aquisição, preparo, e transporte dos objectos e ao pessoal para quasquer serviços referentes a exposição, abrindo para isso os créditos precisos [...]" $]^{\prime 88}$.

O Governo do Maranhão patrocinou a confecção de vários objetos enviados. O valor pago pelo álbum de 1908 deve ter sido mesmo o de 1:900\$, apurado por Jomar Moraes ${ }^{89}$. O serralheiro Euclydes Vianna Bayma, por exemplo, recebeu 200 mil réis do Governo do Maranhão para a elaboração de uma peça enviada para a exposição ${ }^{90}$.

Os objectos do Maranhão enviados para a Repartição de Obras Públicas são os mais variados. De Barreirinhas, Antonio José Godinho remeteu 30 latas de compotas de mangaba, 35 com polpa de burity e 30 de muricy. Raimunda Rodrigues de Araújo, de São Luís, mandou ramos de flores artificiais e José Ramos, do município de Turyassu, uma mascara feita de papel com dentes de tubarão ${ }^{91}$.

Intendência de Pinheiro enviou pele de borracha de seringueira e cera de abelha ${ }^{92}$. Da cidade de Rosário, a senhora Maria Amélia Paz mandou porta-relógio fabricado com fibra de quiabeiro e Manoel Ribeiro da Cruz, duas latas de farinha de banana ${ }^{93}$. Tudo era divulgado

\footnotetext{
${ }^{86}$ Diário Oficial do Maranhão, 26.02.1908.

${ }^{87}$ SILVA FILHO, José Oliveira da. Olhos de ver: a cidade entre as retóricas do visual e do escrito. Monografia de Especialização. (Especialização em História do Maranhão) - CECEN-UEMA, São Luís, 2006. p. 41 -42.

${ }^{88}$ Diario Oficial do Maranhão, 14.04.1908.

${ }^{89}$ SARDINHA, 1987, p. 18.

${ }^{90}$ Diario Oficial do Maranhão, 15.04.1908.

${ }^{91}$ Diário Oficial do Maranhão, 22.04.1908.

${ }^{92}$ Diário Oficial do Maranhão, 22.04.1908.

${ }^{93}$ Diário Oficial do Maranhão, 8.05.1908.
} 
no Diário Oficial do Maranhão. O próprio Domingos Perdigão incluiu cognac e licores feitos por ele, como vinho de ananaz (um tipo de abacaxi) e vinho de genipapo ${ }^{94}$.

Segundo Silva Filho ${ }^{95}$, o local reservado ao Maranhão na exposição não agradou a Perdigão por ser pequeno e distante do salão principal. Ele detalha alguns momentos de glamour do evento, que foi inaugurado em 11 de agosto pelo presidente Afonso Penna, permanecendo aberto até 11 de novembro de 1908.

Domingos Perdigão, segundo Silva Filho ${ }^{96}$ contou com a ajuda de maranhenses ilustres que moravam no Rio de Janeiro, como Coelho Neto, Graça Aranha, Dushee de Abranches e Artur Azevedo. O último, segundo ele, era amigo pessoal de Benedito Leite ${ }^{97}$. No espaço reservado ao Maranhão foi montada uma estante especial com as obras desses autores o que, na opinião dele "retificava o mito da Atenas Brasileira" 98 , um título que cria a idéia do Maranhão ser um 'celeiro de intelectuais'. As interpretações envolvendo esse título são controversas entre os historiadores.

As medalhas e diplomas dos premiados só chegaram ao Maranhão no início de 1911. Foram 219 prêmios, segundo Silva Filho ${ }^{99}$. Um telegrama, a Domingos de Castro Perdigão informou que as comendas estavam sendo enviadas ao Maranhão no Vapor Sergipe $^{100}$. Na área de fotografia, Gaudêncio Cunha ainda ganhou medalha de ouro. Gregório Pantoja ficou com uma de Prata e Zadock Pastor, de Caxias, ficou com uma de bronze. No dia 24 de fevereiro, às 10 horas, eles e os demais ganhadores foram homenageados em uma solenidade organizada no Palácio do Governo do Maranhão ${ }^{101}$.

O número de premiados maranhenses na exposição ocupou várias páginas e duas publicações do Diário Oficial do Maranhão ${ }^{102}$. Várias pessoas receberam o Grande Prêmio, mas o jornal Diário do Maranhão destacou o nome do Governo do Maranhão, Biblioteca do Estado e o de Gaudêncio Cunha como os grandes vencedores maranhenses na exposição. Os demais vêm em seguida entre ganhadores de medalhas de ouro, prata e bronze ${ }^{103}$.

\footnotetext{
${ }^{94}$ Diário Oficial do Maranhão, 15.05.1908.

${ }^{95}$ SILVA FILHO, José Oliveira da. Olhos de ver: a cidade entre as retóricas do vis ual e do escrito. Monografia de Especialização. (Especialização em História do Maranhão) - CECEN-UEMA, São Luís, 2006. p. 32.

${ }^{96}$ Ibid., p. 32-33.

${ }^{97}$ Ibid., 2006, p. 41.

98 Ibid., 2006, p. 33.

99 Ibid., 2006, p. 34.

${ }^{100}$ Diário do Maranhão, 31.01.1911.

${ }^{101}$ Diário O ficial do Maranhão, 19.05.1909.

${ }^{102}$ Diário Oficial do Maranhão, 18 e 19.05.1909.

${ }^{103}$ Diário do Maranhão, 18.02.1911.
} 


\section{CAPÍTULO III}

\section{O ALBUM DO MARANHÃO EM 1908}

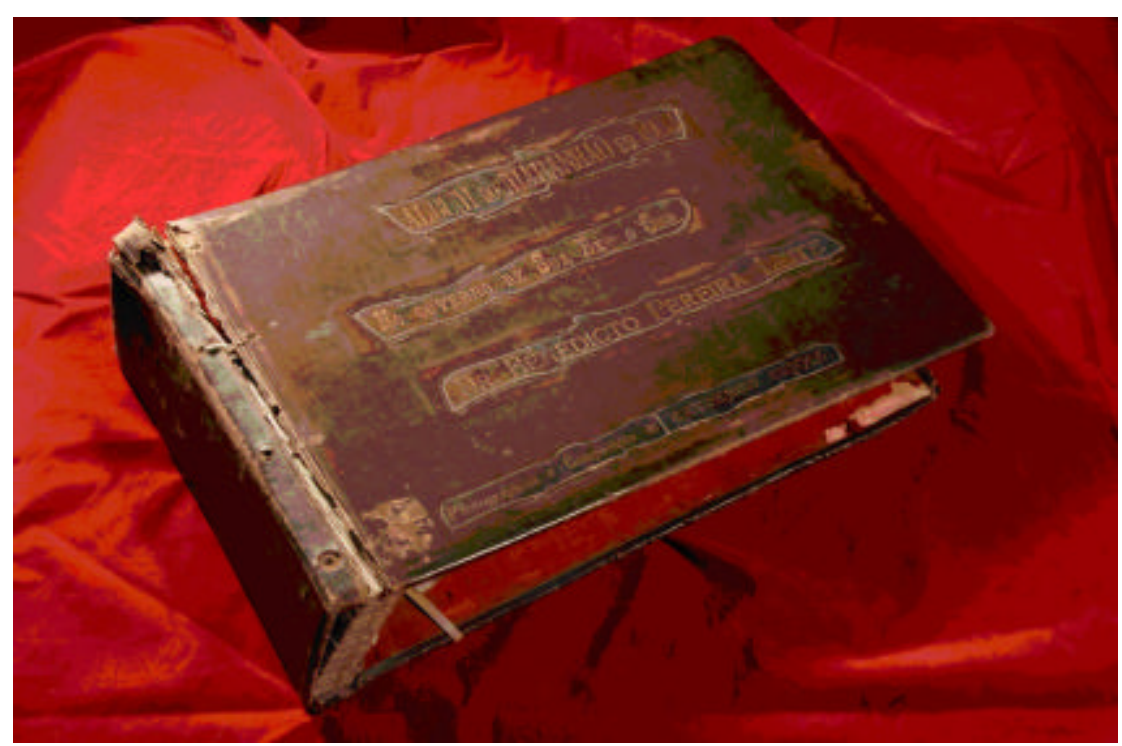

Ilustração 4 - Capa do Album do Maranhão em 1908.

\subsection{Fotografias entre flores}

O único exemplar do Album do Maranhão em 1908 encontra-se no Museu Histórico e Artístico do Maranhão, em São Luís. É um trabalho que a Photographia União fez para o Governo do Estado - na gestão de Benedito Leite (1857-1909) - apresentar na Exposição Nacional de 1908, realizada no Rio de Janeiro. Reúne 211 fotografias que estão distribuídas em 100 páginas, sendo 210 imagens de pais agens urbanas e rurais e um retrato do governador Benedito Leite (Ilustração 8).

O álbum de 1908 tem acabamento aprimorado em detalhes. É um artefato de feições exuberantes, apesar de não ser impresso, como outros do mesmo período. Gaudêncio Cunha deve ter solicitado que artistas de sua época fizessem os serviços de composição, o que inclui a capa em couro (Ilustração 4), a diagramação das páginas (Ilustração 5) e as pinturas de arranjos florais (Ilustrações 6 e 7). A solicitação pode ter sido feita a um de seus colaboradores ou amigos, como o pintor Manoel Valente.

Um detalhe que chama a atenção são os arranjos florais, pintados em várias cores e formas, que circundam as fotografias e decoram os versos das páginas ímpares (Ilustração 6). As pinturas emolduram até o retrato do governador Benedicto Leite (Ilustração 8), 
cuidadosamente recortado de forma oval $(18,5 \times 22,5 \mathrm{~cm})$ e incluído em uma das primeiras páginas do álbum.

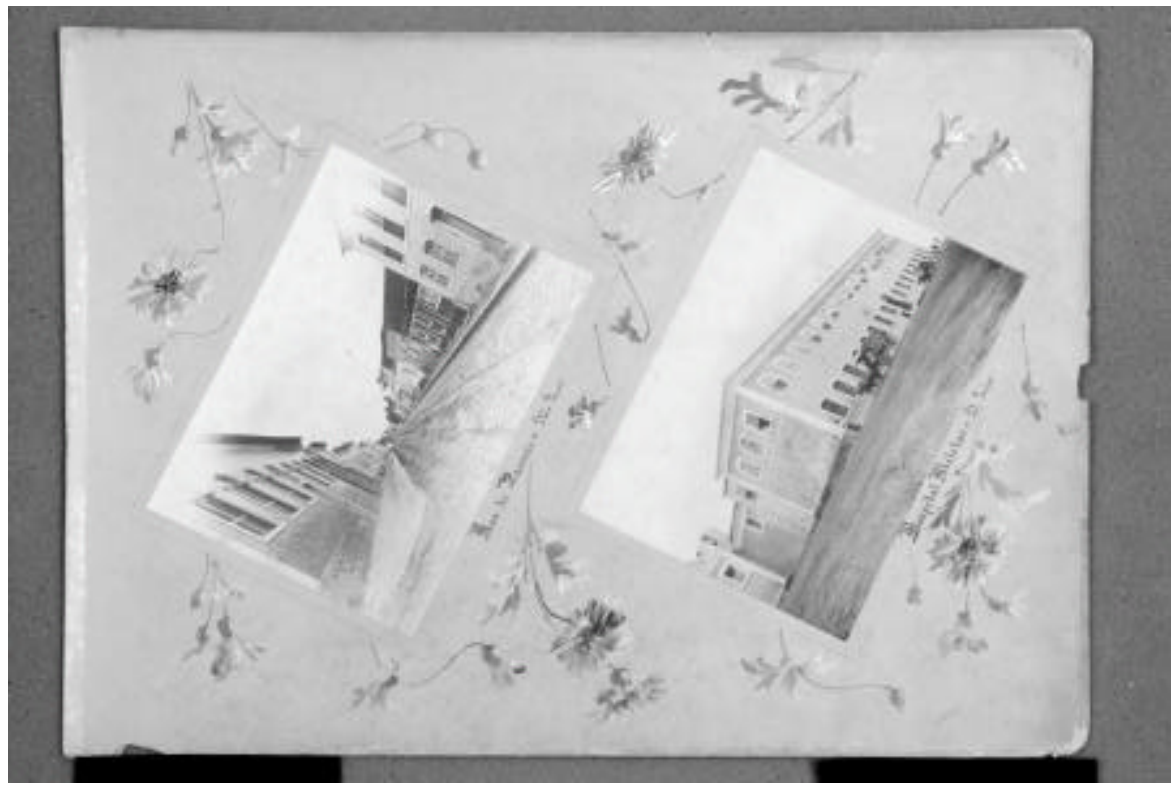

Ilustração 5 - Uma das páginas internas do Album do Maranhão em 1908 com as pinturas de arranjos florais circundando as fotografias.

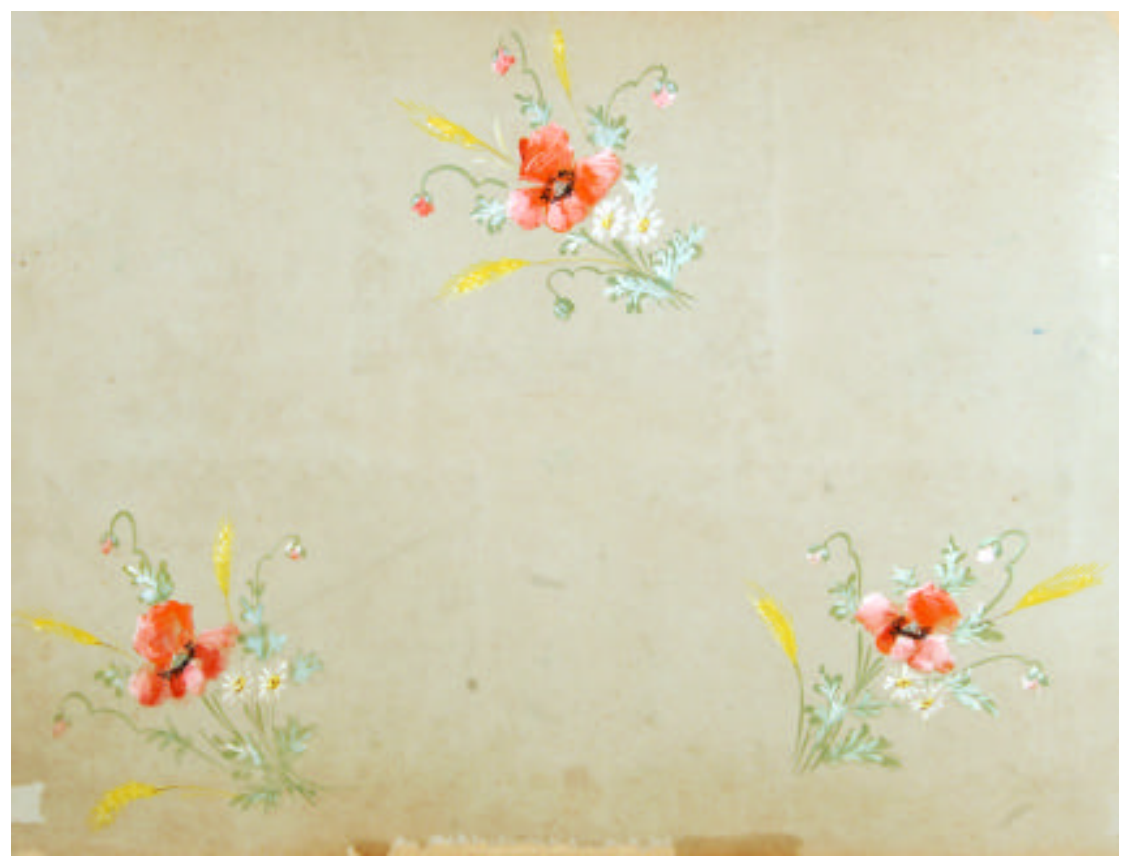

Ilustração 6 - Pintura de arranjos florais no verso de uma das páginas internas do Album do Maranhão em 1908. 


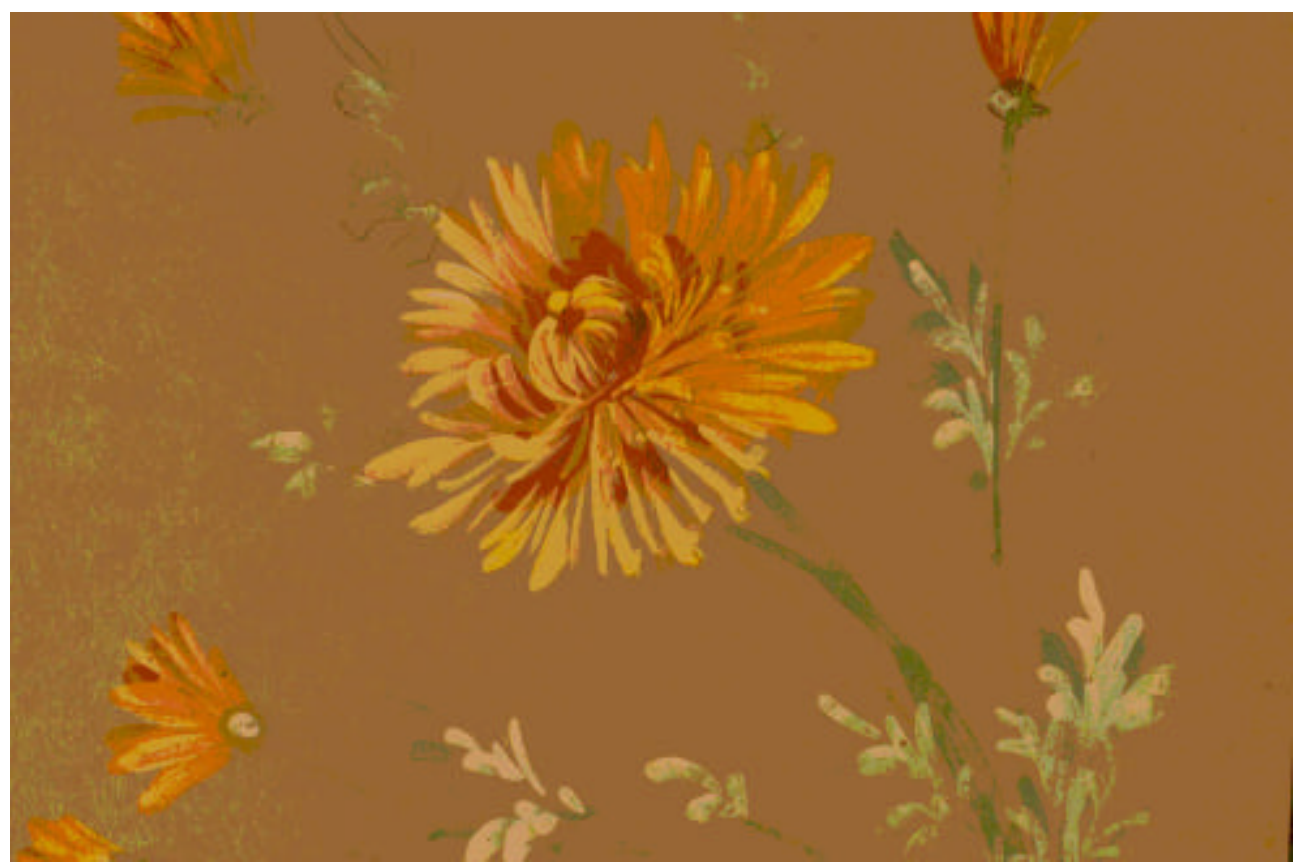

Ilustração 7 - Detalhe de arranjos florais pintados em uma página interna do Album do Maranhão em 1908.

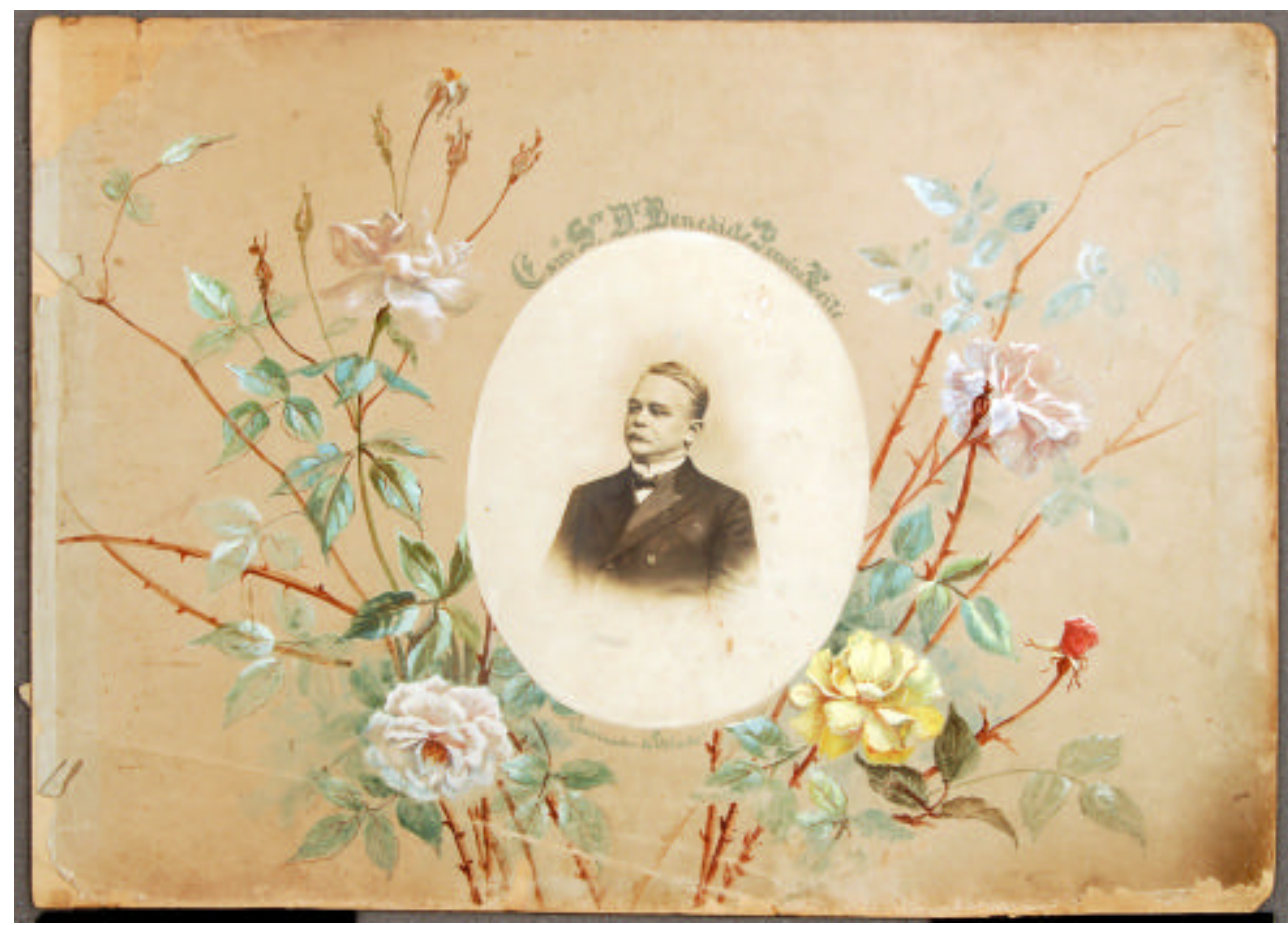

Ilustração 8 - Pinturas de arranjos florais circundando o retrato do governador Benedicto Leite em uma das primeiras páginas do Album do Maranhão em 1908.

Alguns observadores, dentro da segunda realidade, costumam identificar as pinturas das flores como sendo obra de ímpeto feminino. "Essas flores lembram desenhos de bordados de delicadeza e nuança feminina", sugere em tom de humor, em meio a conversas 
informais, a historiadora da arte, Maria Helena Duboc ${ }^{1}$. Ela, contudo, no campo da primeira realidade, adverte que ainda não há qualquer comprovação histórica sobre a autoria das pinturas. "Até o momento não se sabe exatamente quem as desenhou". É provável que tenha sido um amigo colaborador de Cunha, mas ainda não há qualquer evidência sobre o assunto.

O álbum encontra-se no Museu do Maranhão desde o dia 3 de setembro de 1973. Antes era parte do acervo da Biblioteca Pública Benedito Leite (São Luís). De acordo com informações do escritor Jomar Morais, foi parte do acervo de jornais, manuscritos, mapas e outros documentos que o Governo do Maranhão recebeu dos herdeiros do historiador José Ribeiro do Amaral (1853-1927) ${ }^{2}$.

As páginas do álbum foram decompostas para que as fotografias fossem acondicionadas de forma mais adequada, em termos de preservação. Na década de 1980, as imagens foram reproduzidas em uma publicação impressa, organizado pela bibliotecária Maria da Graça Sardinha ${ }^{3}$. Na introdução, o escritor e historiador Jomar Moraes apresentou informações sobre a história da fotografia no Maranhão, com destaque para Gaudêncio Cunha $^{4}$. No novo álbum, há uma nota de esclarecimento informando que a numeração seqüencial das fotos apresentadas obedece à do álbum original ${ }^{5}$. E semelhante ao de tinta nanquim existente no verso das páginas do álbum original.

A capa (Ilustração 4) e a contracapa de couro têm dimensões de 58 x $42 \mathrm{~cm}$. Os versos dessas duas páginas são de veludo. O texto da capa é formado pelos seguintes frases: Album do Maranhão em 1908; No governo de sua EXcia. Benedicto Pereira Leite; Photographia e composição de Gaudêncio Cunha. Entre a capa e a página com a fotografia do governador há uma outra com os seguintes dizeres: Photographia União; De Gaudêncio Cunha; Rua do Sol n. 30; Maranhão - Brasil.

As páginas seguintes possuem uma, duas, três ou quatro fotografias. Todas são circundadas com os desenhos de flores pintadas à mão. São vários os tamanhos das fotografias. A maioria tem em média $15 \times 20 \mathrm{~cm}$ a $26 \times 40 \mathrm{~cm}$, variando para mais ou para menos, dependendo do número de fotografias e da disposição das imagens nas páginas. Há algumas grandes que ocupam toda a página. As legendas aparecem embaixo das fotografias indicando da fotografia que se pretendeu centralizar.

\footnotetext{
${ }^{1}$ Depoimento de Maria Helena Duboc concedido a Jose Reinaldo Castro Martins em 5.6.2007. Ela foi diretora do Museu Histórico e Artístico do Maranhão na década de 1980, quando organizou uma exposição com reproduções das fotografias que compõem o álbum.

${ }^{2}$ SARDINHA, Maria da Graça. Álbum do Maranhão 1908 - Gaudêncio Cunha. Rio de Janeiro, Spala, 1987 p. 17.

${ }^{3}$ Ibid.

${ }^{4}$ Ibid.

${ }^{5}$ Ibid., p. 46.
} 
Silva Filho ${ }^{6}$ acredita que o retrato do governador Benedito Leite (Ilustração 8) personifica o poder e "apresenta expressões de uma estátua, muito comum a partir da segunda metade do século XIX". Ele ainda detectou "atributos de masculinidade pertinente ao período, como o bigode avantajado do governador".

Tudo indica que as duas imagens da Photographia União - uma da fachada e a outra da sala de espera (Fotografias 10 e 11) estão entre as primeiras do álbum, depois da página com o retrato do governador. Há uma página seguinte com duas fotografias, sendo uma do Cais da Sagração (atual Avenida Beira-Mar) e a outra de jornais da época: A Pátria, Diário do Maranhão, Pacotilha, O Maranhão e Diário Oficial. Depois vêm as páginas com fotografias de São Luís e das demais cidades maranhenses. As imagens fotográficas estão sempre nas páginas à direita. Os versos são preenchidos com os desenhos florais decorativos (Ilustração 6).

O álbum é uma seleção de fotografias de paisagens maranhenses que podem ter sido elaboradas até mesmo nos últimos anos da década de 1890. Algumas devem ter sido incluídas de outros álbuns que Gaudêncio Cunha fez anteriormente. Silva Filho ${ }^{7}$ e Jomar Moraes ${ }^{8}$ concordam que há no álbum fotografias de anos anteriores a 1908. Trata-se de uma coletânea de paisagens do Maranhão que Cunha considerou mais apropriadas para serem incluídas. Ele fez uma triagem do material que tinha em mãos, usando o conteúdo, a nitidez e a qualidade no enquadramento como critérios de escolha. Para complementar o conteúdo almejado, ele deve ter acrescentado algumas fotografias feitas em 1908.

\footnotetext{
${ }^{6}$ SILVA FILHO, José Oliveira da. Olhos de ver: a cidade entre as retóricas do visual e do escrito. Monografia de especialização. (Especialização em História do Maranhão) - CECEN-UEMA, São Luís, 2006. p. 40.

${ }^{7}$ Ibid., p. 20.

${ }^{8}$ SARDINHA, Maria da Graça. Álbum do Maranhão 1908 - Gaudêncio Cunha. Rio de Janeiro, Spala, 1987. p. 17.
} 


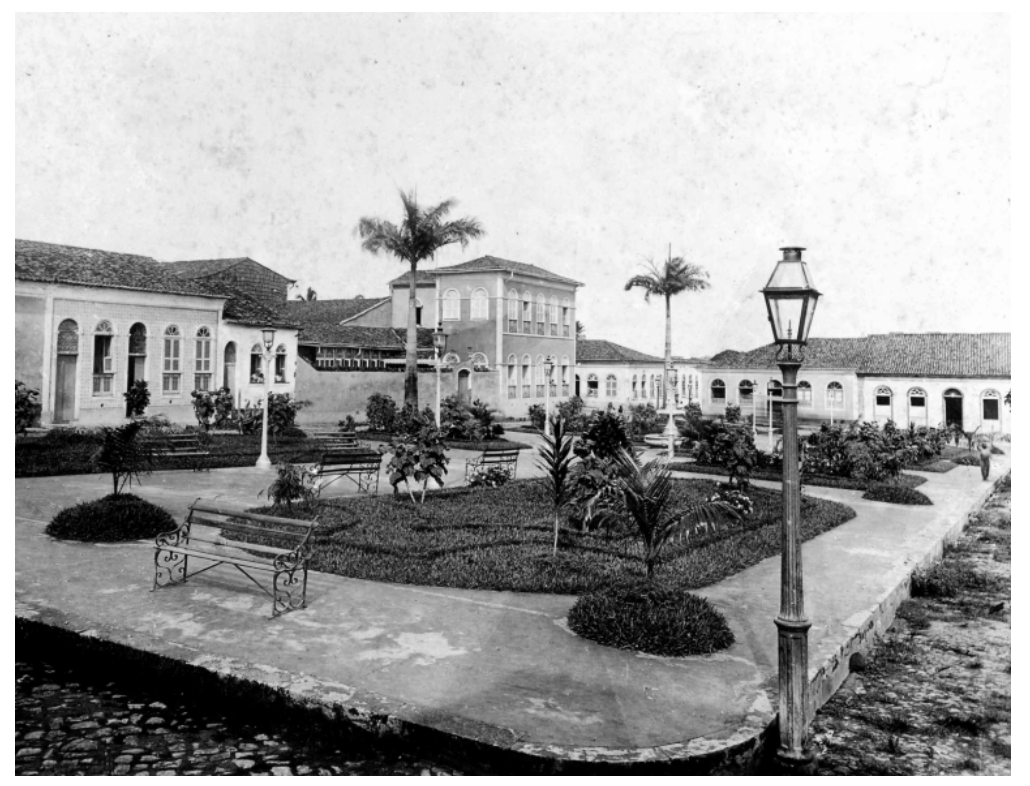

Fotografia 12 - Praça Odorico Mendes. Album.., s.n.p., gelatina/prata, 15 x $20 \mathrm{~cm}$. MHAM.

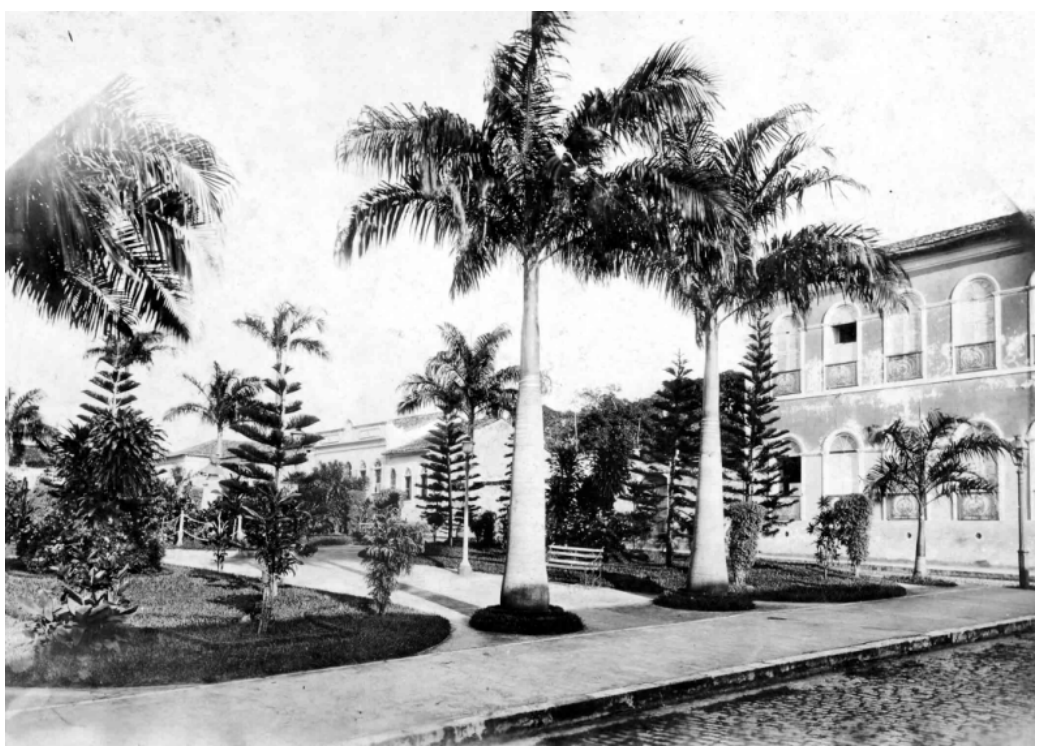

Fotografia 13 Praça Odorico Mendes. Album..., s.n.p., gelatina/prata, $38,5 \times 29,7 \mathrm{~cm}$. MHAM.

A diferença do período em que fotografias do álbum de 1908 foram elaboradas é visível na arborização e jardinagem da Praça Odorico Mendes. Em uma das imagens, as plantas estão pequenas (Fotografia 12). Há somente uma palmeira imperial ao fundo, na área da praça voltada para a Rua dos Remédios. Em outra (Fotografia 13), as plantas da jardinagem da praça estão maiores e há duas palmeiras no trecho da praça voltado para a Rua dos Remédios. Essa segunda foto é ampla e ocupa toda a página, talvez por ser mais atual. A imagem da Estação suburbana (Fotografia 32) foi publicada na Revista do Norte de janeiro de 1906. 


\subsection{Harmonias e paradoxos}

Dentro do senso comum, as pessoas são tentadas a apreciar as fotografias que formam o Album do Maranhão em 1908 como um conjunto de imagens harmoniosas, olhando as paisagens da maneira que desejam. Confortavelmente instalados na segunda realidade costumam enxergam um Maranhão que teria vivido tempos de esplendor e glórias no campo da erudição e na área econômica, em algum momento de seu passado.

Esse sonho de passado de glórias é diretamente vinculado às chamadas singularidades maranhenses que circulam até hoje com desenvoltura em setores como o da propaganda turística. Para Rossini Corrêa ${ }^{9}$, as singularidades maranhenses resistem ao tempo. Vão desde a idéia de terra paradisíaca e hospitaleira do século XVII até o mito da Athenas Brasileira, construído e consolidado no século XIX até o início do século XX.

No mundo da segunda realidade, através de um diálogo entre o observador e a fotografia, o álbum de 1908 é comumente vinculado a um cenário que apresenta o Maranhão como sendo uma sociedade de gente culta, de poetas, prosadores e políticos eficientes. Essa qualidade, tão almejada, na verdade, pode ser identificada como uma singularidade que é encontrada com freqüência na literatura e até na cultura popular do Maranhão produzida ao longo do século XX. O Guia Histórico e Sentimental de São Luís é um bom exemplo de publicação que enaltece singularidades, como a fisionomia acolhedora do maranhense ${ }^{10}$.

Por outro lado, ao se enveredar pelo campo da primeira realidade, é possível descobrir paradoxos entre as composições supostamente harmônicas no Album de 1908. Ao se buscar o ato formador das fotografias aparecem pistas que indiciam a montagem de alguns ajustes que visam esconder contradições e apresentar harmonias.

Um dos paradoxos mais visíveis no Album de 1908 manifesta-se na tensão entre elementos da modernidade almejados pela jovem República do Brasil e uma paisagem urbana que remonta aos tempos do Império/Colônia. É mais ou menos como se encontrássemos metaforicamente falando - galerias subterrâneas entre imagens de ruas arejadas e recortadas por trilhos de bondes. Ou porões escuros e sujos, cheio de velhos baús, sustentando imponentes casarões.

O Brasil, na aurora do século XX, vivia a incerteza decorrente de um regime político recém implantado. A República foi planejada à surdina, através de conchavos em

\footnotetext{
${ }^{9}$ CORRÊA, Rossini. Formação social do Maranhão. O presente de uma arqueologia. São Luís: SIOGE, 1993.

${ }^{10}$ SERRA, Astolfo. Guia histórico e sentimental de São Luís. Rio de Janeiro: Civilização Brasileira, 1965, p.15.
} 
gabinetes e quartéis, apesar de alguns setores mais esclarecidos da sociedade terem manifestado simpatia pelo regime ${ }^{11}$.

A decisão de substituir o regime monárquico pelo republicano em 1889 era desconhecida da grande maioria da população. Por não contar com a participação popular, a República, depois de implantada, clamou por legitimidade. José Murilo de Carvalho ${ }^{12}$ lembra que foi necessário se criar símbolos, como desenhos, estátuas, bandeiras, estandartes e gravuras, com o objetivo de apresentar e referendar o novo regime. Uma outra maneira de tentar dar respaldo à República era ligá-la aos elementos da modernidade pulsantes da época.

No Maranhão, ocorreram poucas alterações sociais e políticas com a passagem do Império para a República. As oligarquias ${ }^{13}$ rurais, segundo Flávio Reis ${ }^{14}$, depois de se dispersarem, se reuniram e se reestruturaram. Benedito Leite foi uma das principais lideranças políticas à frente desse processo. Comandou a reestruturação dos laços de hierarquia política entre as lideranças regionais, após a dispersão vivenciada na crise do Império ${ }^{15}$.

Apesar de ter sido eleito governador somente em 1906, Benedito Leite exerceu influência sobre cinco governadores, desde 1893. Faleceu em março de 1909, na França ${ }^{16}$. Um problema de saúde o impediu de concluir o mandato. A situação "passou a se agravar"17 a ponto de, em maio de 1908, os médicos recomendarem que ele abdicasse ao cargo de Governador do Maranhão ${ }^{18}$.

Collares Moreira (1939), que o sucedeu, na condição de $2^{\circ}$ vice-governador - o $1^{\circ}$ vice, Antônio Belfort Roxo, não pode assumir o cargo - afirma que governadores e deputados obedeciam à orientação de Leite "quer política, quer administrativa"19. Leite, também, tinha a capacidade de exercer sua influência entre intelectuais e políticos, através de relações pessoais de amizade. O próprio Collares Moreira reconheceu isso. "A Benedicto Leite, eu como quase

\footnotetext{
${ }^{11}$ Nos anos antecedentes à queda do Regime Imperial foram criados, em setores médios da sociedade, vários clubes de simpatizantes do regime republicano. Havia jornais que defendiam abertamente a República e criticavam o Império. Ver: MARTINS, Ana Luiza. O despertar da República. São Paulo: Contexto, 2001 e COSTA, 1999, p. 387-392).

12 CARVALHO, José Murilo de. A formação das almas. São Paulo: Companhia das letras, 2002.

${ }^{13}$ O termo 'oligarquia' e as suas derivações vão ganhando significados distintos na história, sociologia e outros setores do conhecimento acadêmico, de acordo com a linha de pensamento adotada. Isso sem falar no uso corrente ao longo do século XX e início do XXI por políticos, populares e jornalistas. O sentido adotado aqui é o definido pelo historiador Flávio Reis (Ver: REIS, Flávio. Grupos políticos e estrutura oligárquica no Maranhão. São Luís: Unigraf, 2007, p. 205) ao longo de sua pesquisa. O assunto é complexo. Mas o autor, em resumo, afirma que oligarquia, na Velha República, é vinculada aos interesses agroexportadores "que envolve uma determinada organização das instâncias de poder, cujo traço mais forte era a rede de favores envolvendo chefes municipais, governadores estaduais e governo federal".

${ }_{14}$ REIS, Flávio. Grupos políticos e estrutura oligárquica no Maranhão. São Luís: Unigraf, 2007. p. 72-85.

${ }^{15}$ Ibid.

${ }^{16}$ VIVEIROS, Jerônimo de. Benedito Leite. Um verdadeiro republicano. Rio de Janeiro: Taveira, 1957.

${ }^{17}$ MOREIRA, Arthur C. Gomes de Castro, Benedicto Leite e Urbano Santos. Rio de janeiro: Jornal do Comércio Rodrigues \& Cia., 1939, p. 52.

${ }^{18}$ Ibid., p. 52-53.

${ }^{19}$ Ibid.
} 
todos meus parentes, nos achá vamos ligados por uma inquebrantável amizade e solidariedade, correspondidas com as maiores provas de confiança" 20 .

Só que dentro desse quadro político e social configurado na passagem no século XIX para o século XX, setores dominantes da sociedade maranhense, representados pelo próprio Benedito Leite, tentaram camuflar a crise no sistema agroexportador que atingiu em cheio a economia ${ }^{21}$. Essa situação é reconhecida até mesmo por historiadores, considerados conservadores, como Jerônimo Viveiros ${ }^{22}$.

A crise havia sido agravada devido a várias questões, sendo a ilegalidade do sistema escravagista uma das mais visíveis ${ }^{23}$. Mesmo assim foi possível erguer, nessa época, um complexo de fábricas no Maranhão, a maioria têxtil ${ }^{24}$. Essas indústrias estão entre os ícones da modernidade presentes no álbum de $1908^{25}$.

$\mathrm{Na}$ visão de Ribamar Caldeira ${ }^{26}$, as fábricas, ao funcionarem plenamente em 1895 , não podiam ser incluídas entre as maiores e mais importantes do Brasil, à época. "Com pequeno número de unidades fabris e pouco diversificados, contava somente com 13 têxteis que davam emprego a 3.075 operários e quatro fábricas de outros ramos: açúcar, metalurgia, calçados e fósforo"27. Apesar das mudanças no sistema produtivo, na década de 1890, o ritmo de crescimento da economia maranhense, dependente do setor comercial, passou por "períodos gerais de expansão e retração"28 . Reis detectou uma estagnação no período de 1899 a $1915^{29}$.

As fábricas e outros elementos da modernidade, como os trilhos de bondes e os serviços da Companhia de Bombeiros, apareceram entre imagens de velhas igrejas e das ruas estreitas, que em alguns momentos o fotógrafo tentou camuflar. Só que esses esforços, apesar de lograr êxitos em alguns enquadramentos, não impediram que as velhas paisagens urbanas de São Luís, do tempo do Império e da Colônia, surgissem impassíveis, em meio à inclusão de elementos da modernidade.

\footnotetext{
${ }^{20}$ MOREIRA, Arthur C. Gomes de Castro, Benedicto Leite e Urbano Santos. Rio de janeiro: Jornal do Comércio Rodrigues \& Cia., 1939. p. 54.

${ }^{21}$ REIS, Flávio. Grupos políticos e estrutura oligárquica no Maranhão. São Luís: Unigraf, 2007. p. 36-45.

${ }^{22}$ VIVEIROS, Jerônimo de. Benedito Leite. Um verdadeiro republicano. Rio de Janeiro: Taveira, 1957. p. 1-47.

${ }^{23}$ REIS, op.cit. p. 38-39.

${ }^{24}$ Ibid., p.38.

${ }^{25}$ Alguns prédios dessas fábricas resistiram ao tempo. Foram restauradas e transformadas em fins do século XX e início do XXI em centros educacionais, espaços de apresentações artísticas e de venda de artesanatos e educacionais. Ver sobre a reforma desses imóveis: ANDRÈS, 1998, p. 78.

${ }^{26}$ CALDEIRAS, Ribamar. Origens da indústria no sistema agro-exportador maranhense (1875/1895). Estudo microsociológico da instalação de um Parque fabril em região do Nordeste Brasileiro no final do século XIX. Tese (Doutorado em Sociologia) FFLCH/USP, 1988, p. 260.

${ }^{28}$ REIS, Flávio. Grupos políticos e estrutura oligárquica no Maranhão. São Luís: Unigraf, 2007. p.41.

${ }^{29}$ Ibid., p.41.
} 


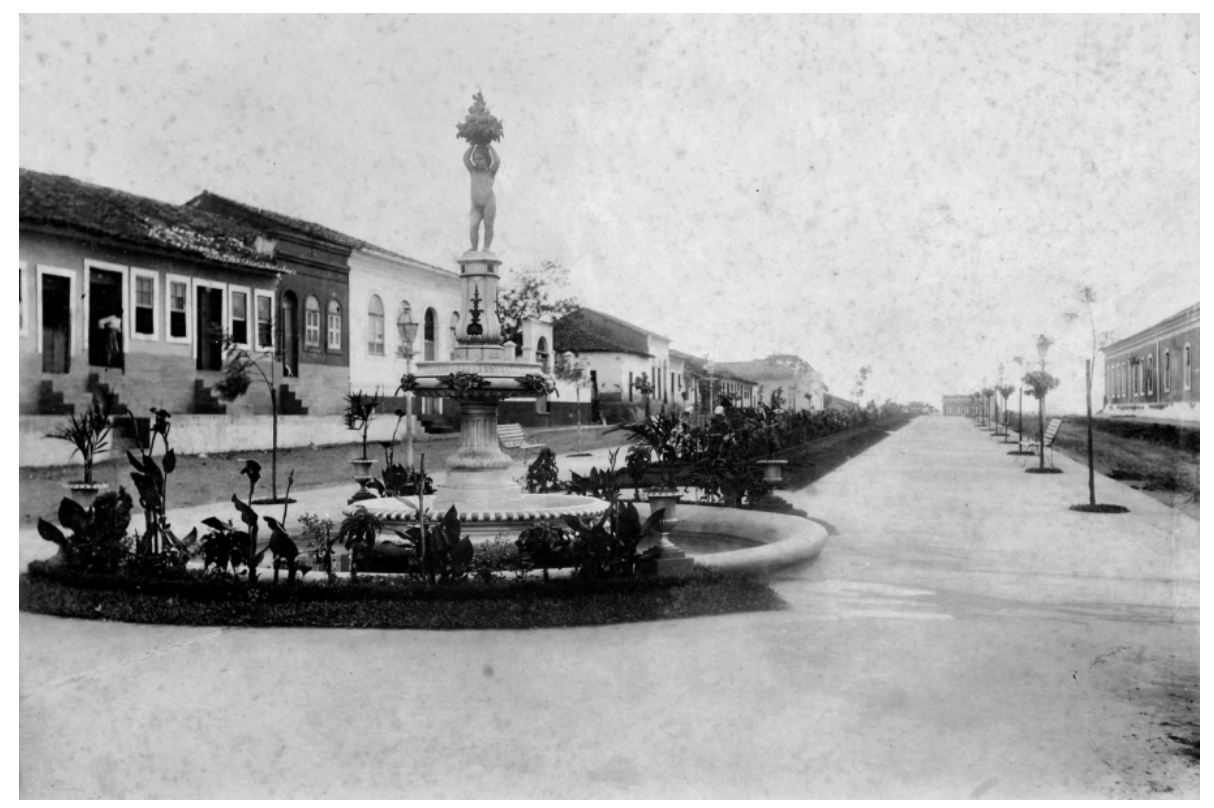

Fotografia 14 Chafariz em um trecho da Avenida Silva Maranhão. Album..., s.n.p., gelatina/prata, 15 x $20 \mathrm{~cm}$. MHAM.

Em meio ao antigo, que se mantém latente, as indústrias, assim com outros ícones da modernidade da recém criada República Brasileira, também se evidenciam no álbum. Há mais de 20 fotografias de fachadas e de ambientes internos de fábricas instaladas em São Luís e em outras cidades maranhenses. Paralelamente, em outra página do mesmo álbum, imagens que lembram o Império, como o chafariz da Avenida Silva Maia (Fotografia 14), dissimulamse indiferentes e elegantes em tempos da modernidade republicana.

Balandier ${ }^{30}$ enfatiza que, antes da modernidade, o passado apaziguava o tempo presente. Na modernidade, o presente passa a recorrer à simulação do futuro ${ }^{31}$. É exatamente na fresta entre essas duas situações que o álbum de 1908 se coloca. Os enquadramentos, as inclusões e exclusões e as acentuações elaboradas pelo fotógrafo formam um conteúdo que indiciam contradições dentro de uma sociedade envolvida em turbulências e inseguranças.

O álbum de 1908 carrega em si os paradoxos de uma sociedade ávida em cultuar um passado que teria acontecido em idos do século XIX - que eles imaginam ter sido glorioso - ao mesmo tempo em que almejavam a modernidade possível em seu tempo, com suas simulações de um futuro promissor. Barros Martins ${ }^{32}$ identifica essa contradição entre intelectuais desse tempo, os chamados Novos Atenienses, ou Operários da Saudade, como os denomina. Para o autor, eles tentavam reviver, em pleno início do século $\mathrm{XX}$, tempos áureos

\footnotetext{
${ }^{30}$ BALANDIER, Georges. O poder em cena. Coimbra: Minerva, 1999.

${ }^{31}$ Ibid., p. 99-102.

${ }^{32}$ MARTINS, Manoel B. Operários da saudade: os novos atenienses e a invenção do Maranhão. São Luís: Edufma, 2006.
} 
do saber maranhense de meados do século XIX. Nesse caso, Gaudêncio Cunha seria o operário da saudade no campo da fotografia.

Na paisagem urbana, o 'velho' e o 'novo' estão em aparente harmonia. Mas, por trás, havia uma tensão movida por uma crise econômica maranhense que inviabilizou grandes transformações na urbanidade de São Luís no início do século XX. A falta de recursos para a modernização da cidade e a preservação de seus aspectos antigos é um assunto complexo e somente agora começa a ser pesquisada com mais profundidade.

Apesar da crise e da construção de boas lembranças de um passado de glórias cultuado por intelectuais na São Luís dos fins do XIX e início do XX, para José Antônio Lopes $^{33}$, em São Luís “a República sonhava com uma cidade moderna”. Vários decretos foram expedidos visando "corrigir defeitos" nas fachadas das edificações. As correções, nada mais eram que uma tentativa de eliminar aspectos antigos (os defeitos) que lembravam os períodos do Império e da Colônia.

Ao contrário da São Paulo do Ciclo do Café, que nas últimas décadas do século XIX teve sua paisagem urbana colonial substituída por outra em estilo neoclássico ${ }^{34}$, e do Rio de Janeiro parcialmente modificada pelo prefeito Pereira Passos, no início do século XX, em São Luís ocorreram somente correções de defeitos. Um decreto de 1896, por exemplo, segundo Lopes $^{35}$, determinou somente que os proprietários realizassem adaptações nas fachadas dos imóveis que, assim, ficariam mais atuais. “[...] obrigatório a modernização dos sobrados que possuíam beirais, através do acréscimo de platibandas e ornamentos, transformando-os em imóveis de estilo eclético [...]"36. (grifo nosso)

A substituição dos beirais (decorações localizadas na área mais alta dos imóveis, logo abaixo dos telhados, que permite o alongamento das telhas frente às fachadas) por platibandas (decorações localizadas na área mais alta da fachada, encobrindo a visão dos telhados), apesar de decretadas oficialmente, deixaram de ser cumpridas, em grande parte. É certo que alguns imóveis ganharam platibandas, um símbolo de modernidade na arquitetura da época. Só que os beirais conservaram-se nas fachadas dos imóveis do perímetro urbano de São Luís. Algumas pequenas mudanças foram efetivadas, mas nada que comprometesse a

\footnotetext{
${ }^{33}$ LOPES, José A. V. Os intelectuais e a preservação do patrimônio cultural de São Luís. In: PONTUAL, V;CARNEIRO A. R. História e paisagens: ensaio urbanístico do Recife e de São Luís. Recife: Bagaço, 2005. p. 243, 245.

${ }^{34}$ No documentário "Sinfonia em quatro tempos", o cineasta Carlos Eduardo Paranhos Ferreira contextualiza as mudanças mais significativas que aconteceram na paisagem urbana da cidade de São Paulo ao longo dos anos, inclusive a substituição do sítio colonial pela Cidade do Café. Cópias disponíveis na Biblioteca Central da Unicamp, Biblioteca do Instituto de Artes da Unicamp, Biblioteca da ECA-USP e Biblioteca da Fau-Usp. Ver mais em (KOSSOY, 1988a) e (KOSSOY, 1988b).

${ }^{35}$ LOPES, José A. V. Os intelectuais e a preservação do patrimônio cultural de São Luís. In: PONTUAL, V;

CARNEIRO A. R. História e paisagens: ensaio urbanístico do Recife e de São Luís. Recife: Bagaço, 2005.

${ }^{36}$ LOPES, op. cit., 2005, p. 243, grifo nosso.
} 
preponderância paisagem Imperial/Colonial, como aconteceu em São Paulo e com parte do Rio de Janeiro.

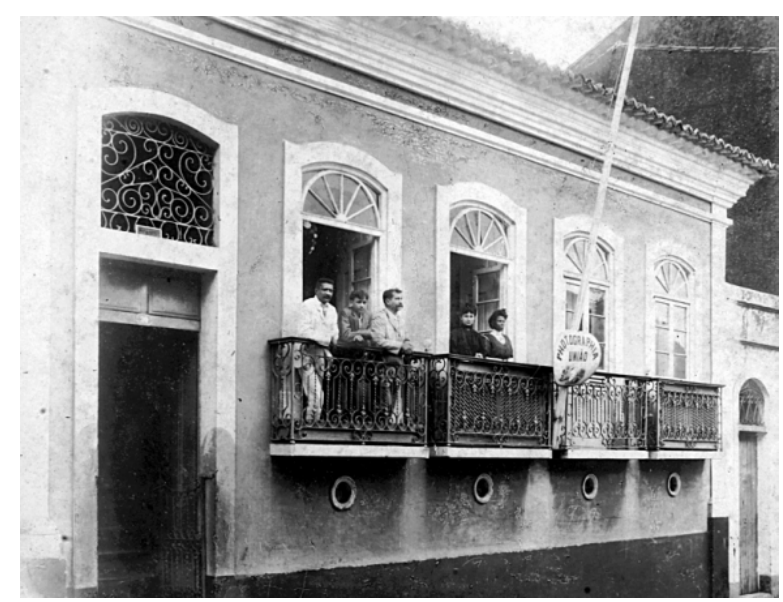

Fotografia 15 - Fachada da Photographia União com beirais. Album..., s.n.p., gelatina/prata, 22,5 x $17 \mathrm{~cm}$. MHAM.

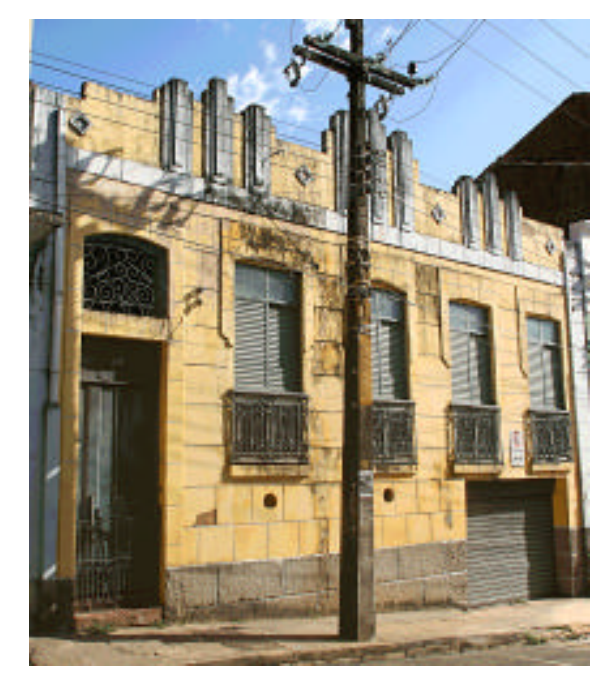

Ilustração 9 - Nova fachada da Photographia União com platibandas.

O prédio da Photographia União da Rua do Sol é um exemplo de imóvel que teve os beirais substituídos por platibandas, o que aconteceu depois da morte de Cunha. Por causa dessa e de outras significativas mudanças na fachada do imóvel, houve dificuldades para localizar a posição da Photographia União na Rua do Sol. 


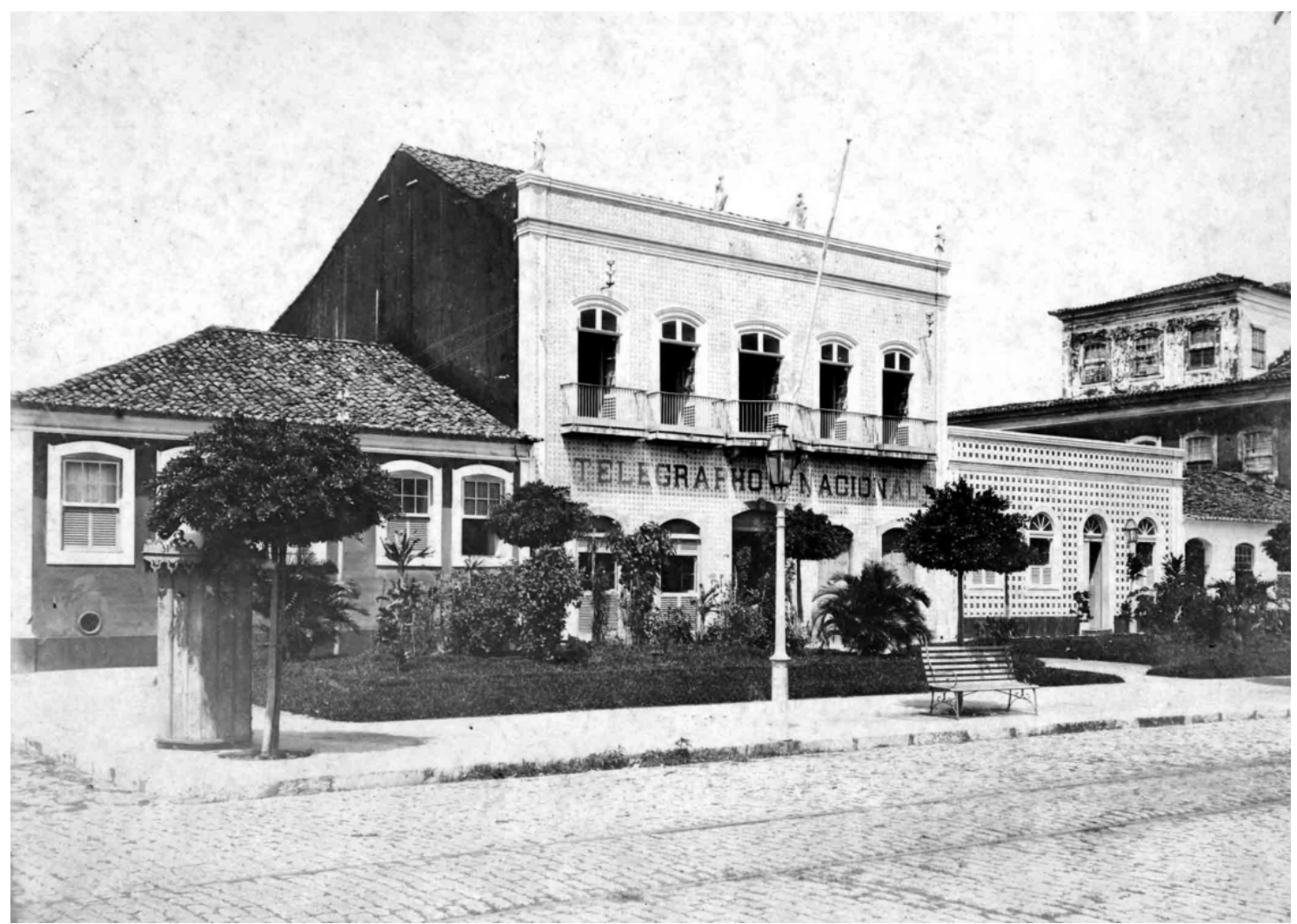

Fotografia 16 - Fachada do Telegrapho Nacional. Album..., s.n.p., gelatina/prata, 15 x $20 \mathrm{~cm}$. MHAM.

Algumas sedes dos modernos serviços públicos e privados estão instaladas em prédios que apresentam tendências arquitetônicas do tempo do Império e da Colônia, mesmo quando os beirais são substituídos por platibandas. A sede do Telegrapho Nacional já aparece no álbum com os beirais substituídos por platibandas. Mas, nos imóveis ao lado, um tem beirais e o outro é ornado com platibandas. Ou seja: os beirais permanecem nas fachadas de boa parte dos imóveis incluídos no álbum, apesar do decreto reportado por Lopes ${ }^{37}$ que determinou a substituição por platibandas.

Em algumas fotografias, Cunha manteve alguns desses imóveis, com platibandas ou beirais quase em segundo plano, para, dessa forma, poder enquadrar os trilhos na composição fotográfica.

${ }^{37}$ LOPES, José A. V. Os intelectuais e a preservação do patrimônio cultural de São Luís. In: PONTUAL, V; CARNEIRO A. R. História e paisagens: ensaio urbanístico do Recife e de São Luís. Recife: Bagaço, 2005. p. 243-244. 


\subsubsection{Gente nas paisagens}

No álbum de 1908, embora haja pessoas compondo as fotografias, o foco central e dominante são as paisagens urbanas e os prédios. Mesmo assim, é evidente a presença de pessoas. Em uma de suas várias referências à presença de pessoas em fotografias de rua, Kossoy alerta para a importância de se "[...] desvendar a vida implícita das imagens, além do véu de pedra, concreto e ferro das realizações materiais que caracteriza m as tradicionais vistas $[\ldots]^{, 38}$.

Considerando essas questões, a composição de conteúdo elaborada por Gaudêncio Cunha evoca duas questões.

a) Quais as finalidades pretendidas quando ele priorizou construções arquitetônicas e paisagens urbanas em que a presença de pessoas é insignificante na grande maioria das vezes?

b) Se a preferência foi apresentar belas paisagens urbanas e edificações como atestam as legendas - então por que, às vezes, os indivíduos aparecem quase despercebidos?

Primeiramente, é preciso atentar para os problemas envolvendo técnica fotográfica disponível. Nos estúdios, os fotógrafos encontravam mais facilidade em paralisar as pessoas quando elas eram retratadas. Em ambientes externos era difícil manter as pessoas em condições apropriadas, em termos de nitidez, uma marca de qualidade perseguida por profissionais perfeccionistas como Gaudêncio Cunha.

Com relação ao primeiro questionamento, é evidente que ele priorizou ruas, praças, embarcações e imóveis (prédios públicos, igrejas, ambientes internos, fábricas e imponentes residências), porque atendia às expectativas do seu cliente, pois o álbum é uma encomenda. O cliente queria apresentar, antes de tudo, o que havia de civilidade edificante, de paisagem européia no Maranhão.

Quanto ao segundo questionamento, os transeuntes estão ali, mesmo os que parecem ter sido convidados para posar, porque fazem parte da paisagem. Podem até ter sido incluídos por determinação do fotógrafo, em alguns casos. Mas, em poucos casos, eram necessários como parte do conteúdo almejado pelo cliente para ser apresentado na exposição do Rio de Janeiro.

\footnotetext{
${ }^{38}$ KOSSOY, Boris. Luzes e sombras da metrópole: um século de fotografias em São Paulo (1850-1950). In: PORTA, Paula. História da Cidade de São Paulo. A Cidade no Império 1823-1889. São Paulo: Paz e Terra, 2004a. v.2. p. 385-455. 2004a, p. 388.
} 


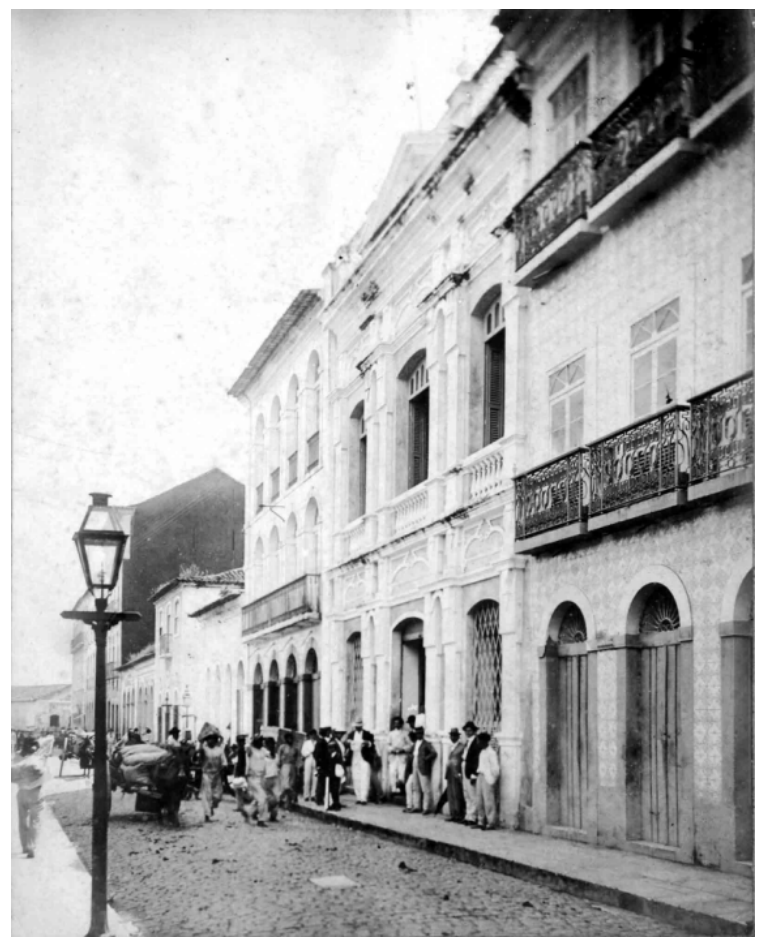

Fotografia 17 - Rua Portugal com pessoas em frente. Album..., s.n.p., gelatina/prata, $18 \mathrm{x}$ $14,5 \mathrm{~cm}$. MHAM.

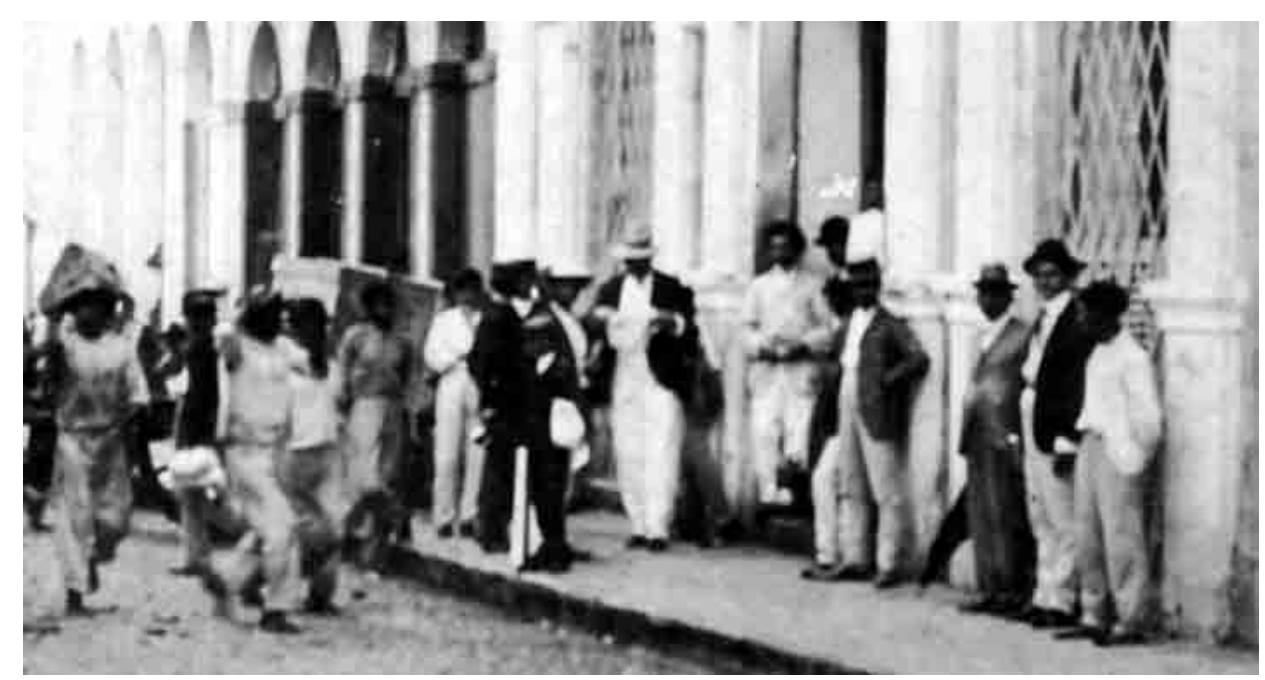

Ilustração 10 - Transeuntes transportando mercadorias na Rua Portugal. Detalhe da Figura 17. 


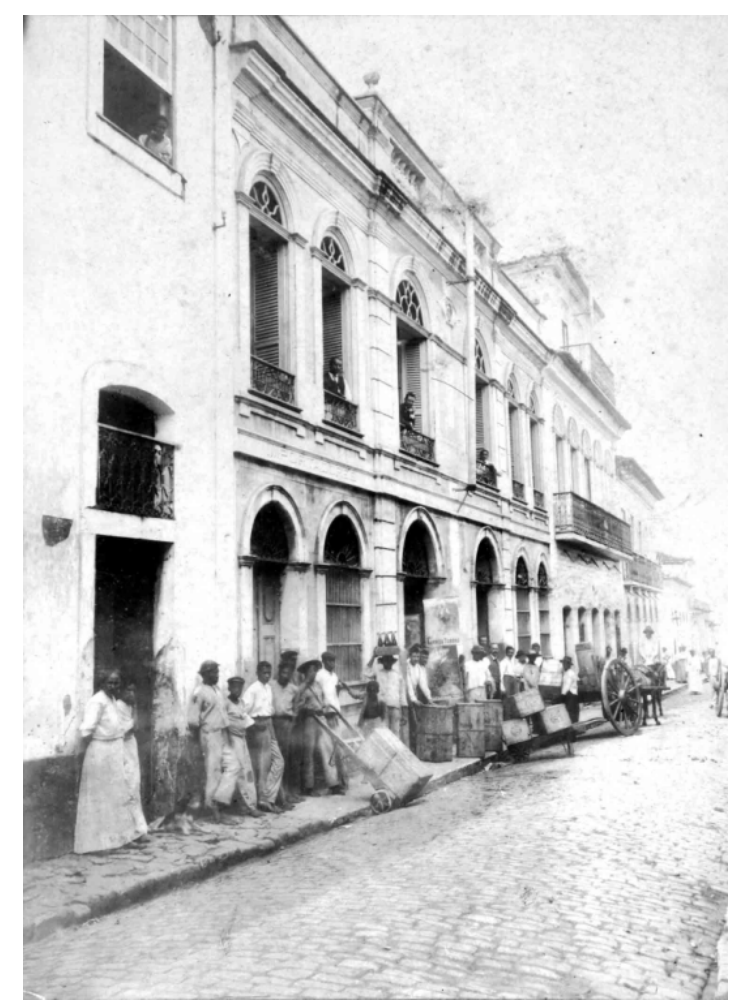

Fotografia 18 - Rua Portugal com pessoas em frente aos armazéns. Album..., s.n.p., gelatina/prata, 20,4 x 15cm. MHAM.
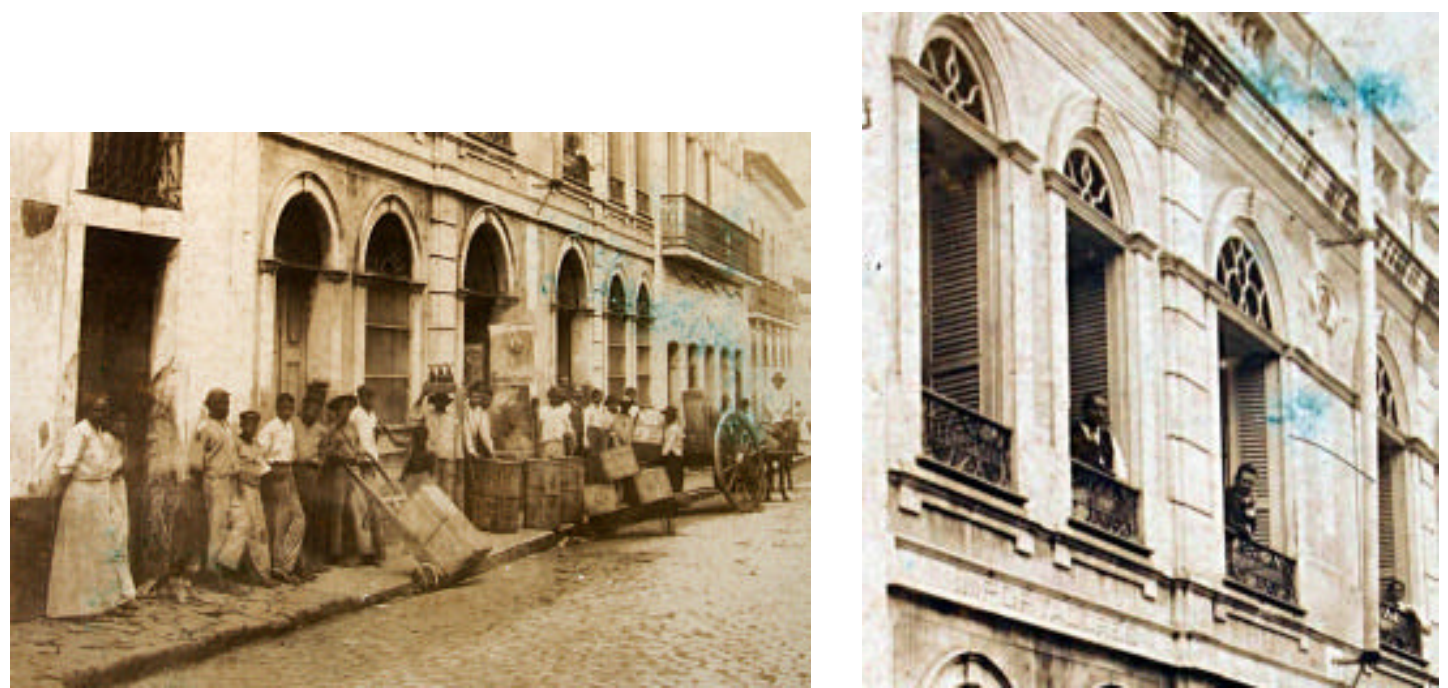

Ilustração 11 - Jovens transeuntes descalços. Detalhe da Fotografia 18

Ilustração 12 - Pessoas na janela de casa comercial. Detalhe da Fotografia 18. 


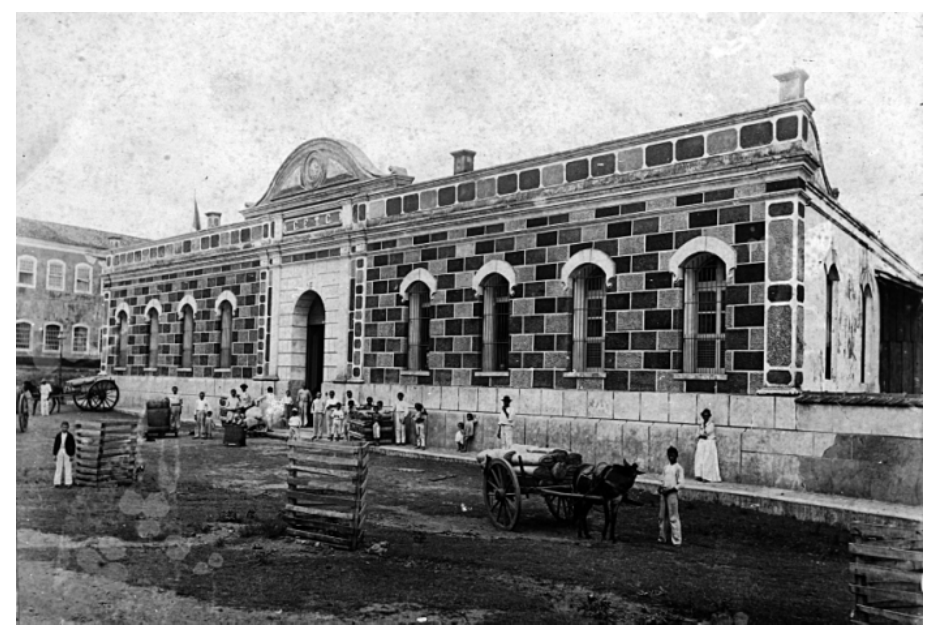

Fotografia 19 - Fábrica Cânhamo com pessoas na frente. Album..., s.n.p., gelatina/prata, 21 x $29 \mathrm{~cm}$. MHAM.

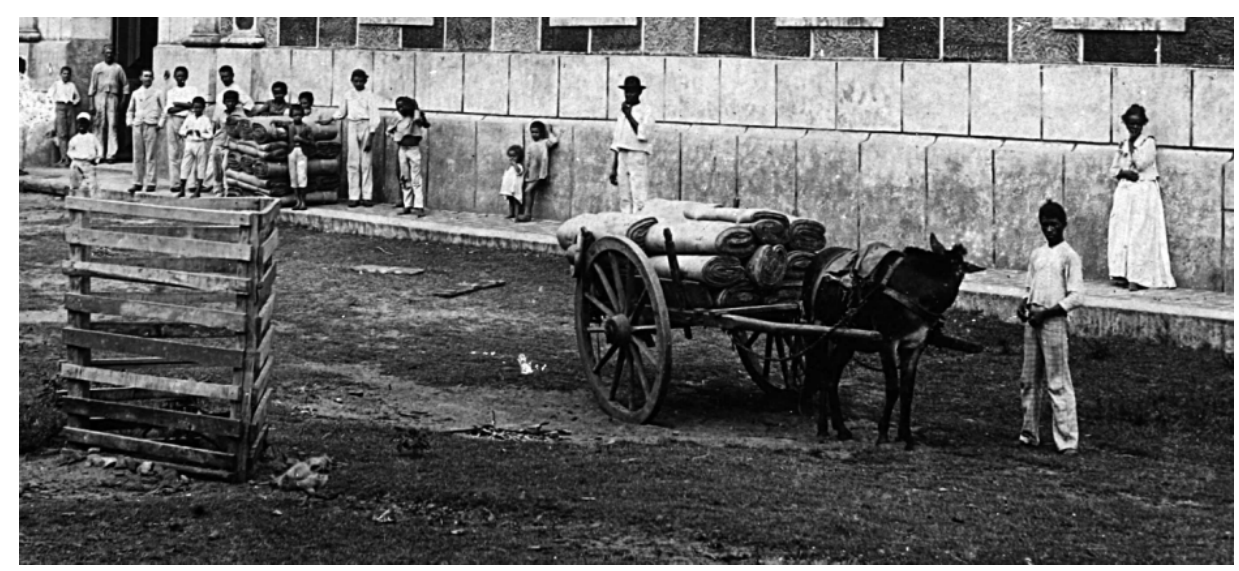

Ilustração 13 - Pessoas na porta da Fábrica Cânhamo. Algumas estão descalças. Detalhe da fotografia 19.

Fora a imagem do governador, há poucas fotografias em que as legendas reportam-se as pessoas. Em uma há referência aos fazendeiros do Vale do Pindaré e na página dedicada à Companhia de Bombeiros cita-se a presença de inferiores e praças (Ilustração 14 e 51). Em menos de 10, das mais de 200, elas compõem parte do primeiro plano. Em mais da metade, as pessoas estão totalmente ausentes.

No entanto, em algumas fotografias, nas quais os prédios e paisagens urbanas ainda são as prioridades, os transeuntes maranhenses estão presentes, posando nos interstícios. Só que estão distantes, em trechos das ruas, calçadas e praças. Chegam às portas, espiam nas sacadas das janelas, como que atraídos pelo trabalho do fotógrafo. Posam na porta das fábricas (Fotografia 19), talvez sem saber para quê. Mas, no fundo, quase todos transmitem a sensação de estarem no lugar onde sempre estiveram. Ao contrário dos nativos das fotografias 
etnográficas do século XIX que chegaram a ser colocados em cenários totalmente infreqüentes a eles, como já foi explicado no Capítulo I.

Em alguns momentos, há a impressão de que Gaudêncio Cunha permitiu ou até fomentou a presença de transeuntes entre as imagens que ele selecionou do conjunto de paisagens que ele já tinha do Maranhão. Por outro lado, o seu cliente deixou passar esses conteúdos, talvez por considerar detalhes inexpressivos diante do predomínio de edificações e espaços urbanos.

O mais provável é que os transeuntes, como os que transitavam nas praças e ruas como a Rua Portugal (Fotografias 17 e 18 e Ilustrações 10 e 11) ou posaram em frente às fábricas (Fotografia 19 e Ilustração 13) estão pelos dois motivos. É uma concessão ou anseio do fotógrafo, ao mesmo tempo em que estão $l^{39}$ porque é parte inseparável do cenário maranhense da época. Com um pouco de esforço poderiam ser excluídos do foco, mas, ao que tudo indica não foi essa a intenção de Gaudêncio Cunha.

Algumas pessoas, principalmente as mais humildes, parecem ser inadequadas, em alguns casos, ao ideário encomendado pelo cliente de Gaudêncio Cunha. Porém são incluídas no conteúdo das fotografias. Estão impassíveis, como se fosse impossível para o fotógrafo descartá-las. Estão lá, como diria Barthes ${ }^{40}$, tal qual um punctum chamando a atenção de quem os observa. Sobrevivem na fotografia, às vezes olhando sorridentes para a câmara.

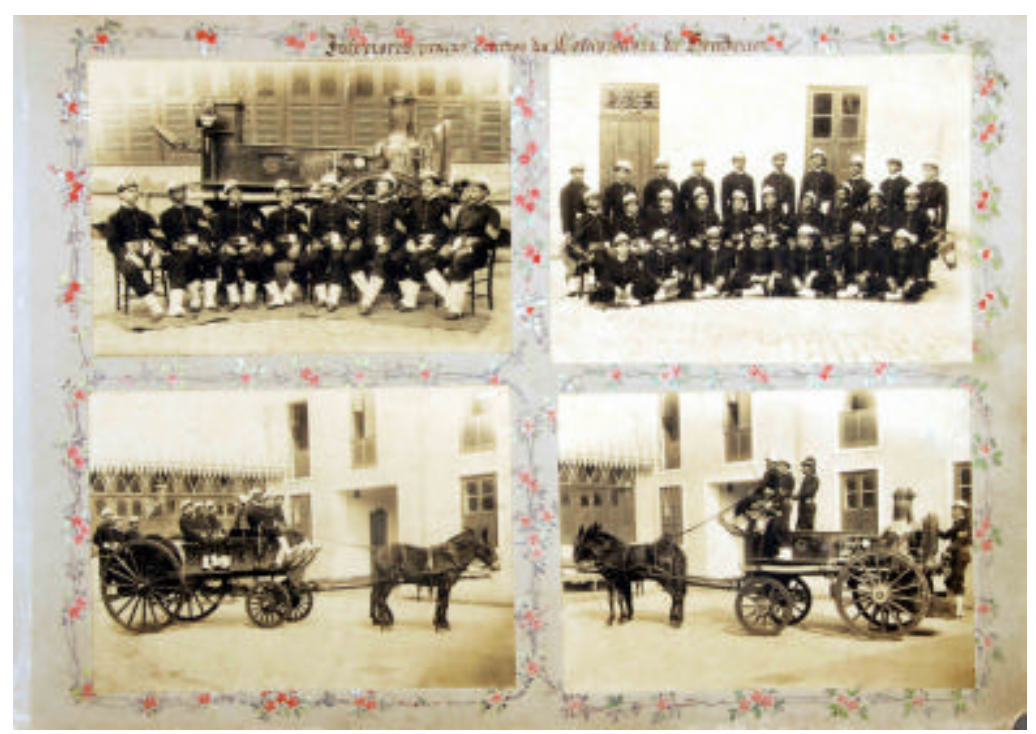

Ilustração 14 - Página do Album do Maranhão em 1908 com fotografias de inferiores e praças da Companhia de Bombeiros. Realizada com autorização da diretoria do MHAM.

\footnotetext{
${ }^{39}$ BARTHES, Roland. A câmara clara. Rio de Janeiro: Nova Fronteira, 1984

${ }^{40}$ Ibid.
} 
Só que as pessoas estão no fundo do foco, compondo a fotografia apenas como figurantes dentro de um cenário que privilegia as paisagens urbanas, os serviços modernos e imóveis imponentes. Gaudêncio Cunha expõe algumas pessoas em primeiro plano, quando quer deixar transparecer a existência de relações livres entre brancos e negros, mais adequadas aos novos tempos republicanos. Uma imagem inversa ao modelo escravagista. Os homens da Companhia de Bombeiros (Fotografia 14 e 51) são os que melhor traduzem essa tendência. Brancos e negros aparecem sentados, lado a lado como é apropriado a uma sociedade que colocou a escravidão na ilegalidade.

Por outro lado, em algumas fotografias, a pretensa transposição da escravidão para o mundo livre parece não ter acontecido na prática. A parasservidão entre coronéis e os agregados que remonta o Maranhão Imperial/Colonial se refaz em imagens de ruas, nas calçadas dos armazéns e nas portas das fábricas.

O Brasil Republicano precisava acompanhar os novos tempos. Era necessário ter ruas largas para os carros, cidades higienizada, entre outras novidades e necessidades da época. Só que o velho país rural, com suas imagens que lembravam a escravidão ainda clamava por espaço. Viotti da $\operatorname{Costa}^{41}$ acredita que debilidades das classes médias e do proletariado urbano dessa época no Brasil proporcionaram a preponderância do poder oligárquico e rural até o início da década de 1930, o que influenciou na manutenção de uma imagem escravagista no Brasil. A observação de Viotti da Costa é recorrente nas fotografias do álbum de 1908.

Pelas calçadas e ruas, em frente às fábricas e casas comerciais, negros e mestiços fazem o fundo das imagens fotográficas (Fotografias 17 e 18 e Ilustrações 10 e 11). Adultos, jovens e crianças, homens e mulheres agregam-se próximos a suas áreas de trabalho, ou se achegam por residirem nas proximidades (Ilustração 13). Por que Gaudêncio Cunha manteve essas pessoas nas fotografias? Usando calças e vestidos de algodão grosseiro, negros e mestiços posam carregando mercadorias ou conduzindo carroças. Desempenham as mesmas atividades que seus pais ou alguns deles exerciam no tempo da escravidão. Em plena República, jovens aparecem descalços, tal qual índios e negros cativos presentes nas imagens etnográficas do século XIX.

Os brancos que aparecem nas janelas dos andares superiores de uma das casas comerciais da Rua Portugal (Ilustração 12) lembram os senhorios do tempo da escravidão. É

\footnotetext{
${ }^{41}$ COSTA, Emília Viotti. Da Monarquia à República. São Paulo, UNESP, 1999. p. 490.
} 
certo que em tempos republicanos, alguns brancos vão para as calçadas dos armazéns, mas bem vestidos e sempre calçados.

As camadas mais privilegiadas da população são atraídas para as ruas pelas "atividades sociais modernas" religiosas, como as procissões ${ }^{43}$. Nas fotografias de São Luís, uma das causas que parece ter levado alguns brancos foi o próprio ato fotográfico. Há momentos em que os brancos estão quase em primeiro plano, posando em frente a fábricas de tecidos, enquanto trabalhadores, a maioria mulheres, faz o pano de fundo.

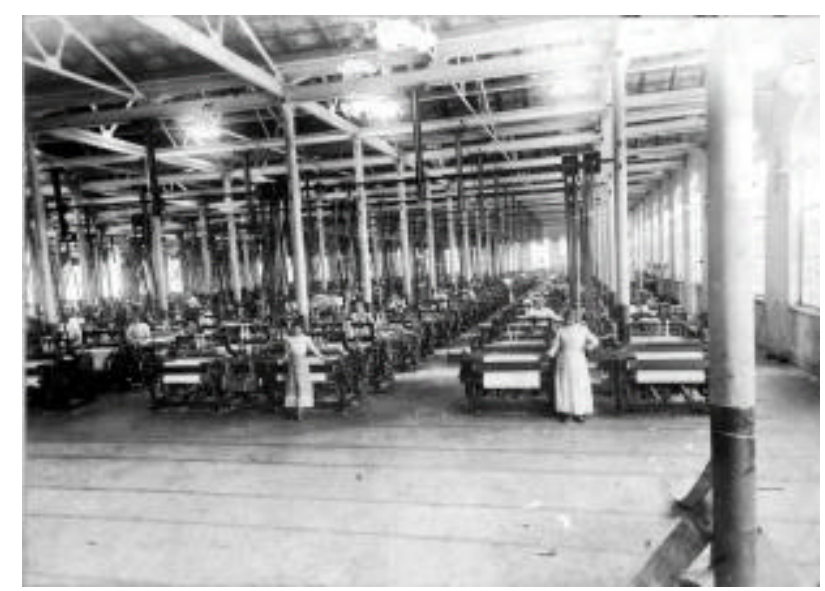

Fotografia 20 - Mulheres trabalhadoras posam dentro de uma fábrica. Album..., s.n.p., gelatina/prata, 14 x $19,8 \mathrm{~cm}$. MHAM.

Em outras fotografias Gaudêncio Cunha apresenta na imagem interna de uma fábrica, outra composição adequada do trabalho livre, aos novos tempos de ilegalidade da escravidão. A forma ideal que a nova sociedade republicana desejava para si. Ali, mulheres operárias se apresentam bem compostas, ao lado das máquinas têxteis (Fotografia 20).

Glória Correia $^{44}$ observa que os negros formaram um contingente importante de trabalhadores nas fábricas desse tempo ou chegaram mesmo a terem representação maciça. Interessante quando a autora percebe as permanências e as novidades caminhando juntas. A marcação das horas, segundo ela, passou a ser cadenciada pelos apitos das fábricas e pelos sinos das igrejas ${ }^{45}$. Para a historiadora, "no contexto e na forma como foram implantadas, as fábricas não poderiam ser 'algo a mais' numa cidade antiga, com uma sociedade solidamente

\footnotetext{
${ }^{42}$ FREHSE, Fraya. O tempo das ruas. São Paulo: Edusp, 2005. p. 30.

${ }^{43}$ Ibid., p. 30 e 97.

${ }^{44}$ CORREIA, Maria da Glória G. Nos fios da trama: quem é essa mulher? Cotidiano e trabalho do operariado feminino em São Luís na virada do século XX. São Luís: EDUFMA,2006, p. 186.

${ }^{45}$ Ibid., p. 185.
} 
estruturada"46. A estudiosa observa que as fábricas "não poderia deixar de constituir referências morais e materiais novos, não significando que as mudanças necessariamente negassem as continuidades"

\subsubsection{Trilhos em ruas estreitas}

As ruas estreitas de São Luís, desde meados do século XIX não agravam os visitantes, principalmente os cientistas que passaram pela cidade em meados do século XIX e início do XX. O casal de estudiosos da área de botânica, Luiz Agassiz (1807-1873) e Elizabeth Cary Agassiz, na visita a São Luís em 6 e 7 de agosto de 1865 teceram críticas a sua composição urbanística. Certamente por causa das ruas estreitas e devido ao clima, eles optarem em dormir na embarcação que os conduziam a uma viagem pelo Norte do Brasil ${ }^{48}$. “[...] Não deixamos de ficar, todavia, no navio, pois preferimos passar a noite no mar a passála na cidade apertada e muito quente $[\ldots . ., 49$.

O viajante Annibal Amorim ${ }^{50}$, em seu relato sobre a viagem realizada em 1909, enaltece o "passado de glórias" como uma singularidade maranhense e a arborização de São Luís, mas se incomoda com as formas das ruas que, para ele eram defeituosas. "[...] são, em geral estreitas, segundo o antigo gosto portuguez. Porém, muito asseiadas [...]"51.

Os Agassiz e Amorim traziam consigo a imagem formada de urbanidade moderna, atrelada à idéia de vias bem modeladas e, sobretudo, largas. São Luís, para a decepção deles tinha formas de ruas quase opostas a dos largos "boulevards" de cidades como a Paris da Belle Époque (1890-1910) ${ }^{52}$.

\footnotetext{
${ }^{46}$ Ibid.

${ }^{47}$ Ibid.

48 AGASSIZ, Luiz; AGASSIZ, Elizabeth C. Viagem ao Brasil 1865-1866. São Paulo: Companhia Editora Nacional, 1938. p. 10.

${ }^{49}$ Ibid., p. 182.

${ }^{50}$ AMORIM, Aníbal. Viagem pelo Brasil. Do Rio ao Acre - Aspectos da Amazônia - Do Rio a Matto Grosso. Rio de Janeiro: Livraria Garnier, 1917. p. 114.

${ }^{51}$ AMORIM, Aníbal. Viagem pelo Brasil. Do Rio ao Acre - Aspectos da Amazônia - Do Rio a Matto Grosso. Rio de Janeiro: Livraria Garnier, 1917.p. 114.

${ }^{52}$ HAROUEL, Jean-Lous. História do Urbanismo. Campinas: Papirus, 1990. p. 110-113.
} 


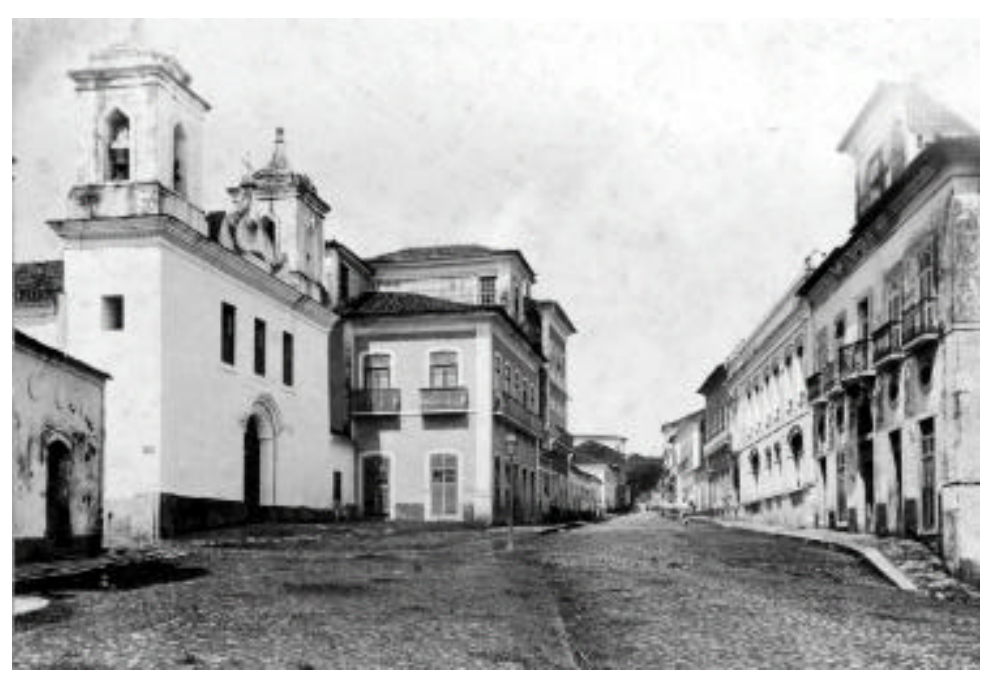

Fotografia 21 - Rua do Egypto e igreja do Rosário Album..., s.n.p., gelatina/prata, $15,5 \times 20,5 \mathrm{~cm}$. MHAM.

Usando os recursos técnico-fotográficos de sua época, Gaudêncio Cunha conseguiu, em algumas fotografias, a magia de tentar amenizar e até mesmo 'esconder' as ruas estreitas de São Luís. A parte da Rua do Egito (Fotografia 21) centralizada é justamente o trecho mais largo que fica próximo da igreja do Rosário. A fotografia parece pedir que o restante da rua, ao fundo seja alargado.

Em outras fotografias, ele inclui apenas uma parte da rua em primeiro plano e os imóveis citados nas legendas aparecem em segundo plano, escondendo o tamanho das ruas.

As ruas estreitas intervieram até nos ângulos selecionados pelo fotógrafo. O prédio da Photographia União (Fotografia 15) é focado um pouco de viés. Talvez por ser difícil fotografar toda a fachada de frente, devido à largura da via e, mesmo sendo estreita, a Rua do Sol ainda era mais larga que as suas várias vicinais, como a Rua dos Craveiros, onde Gaudêncio Cunha residiu. 


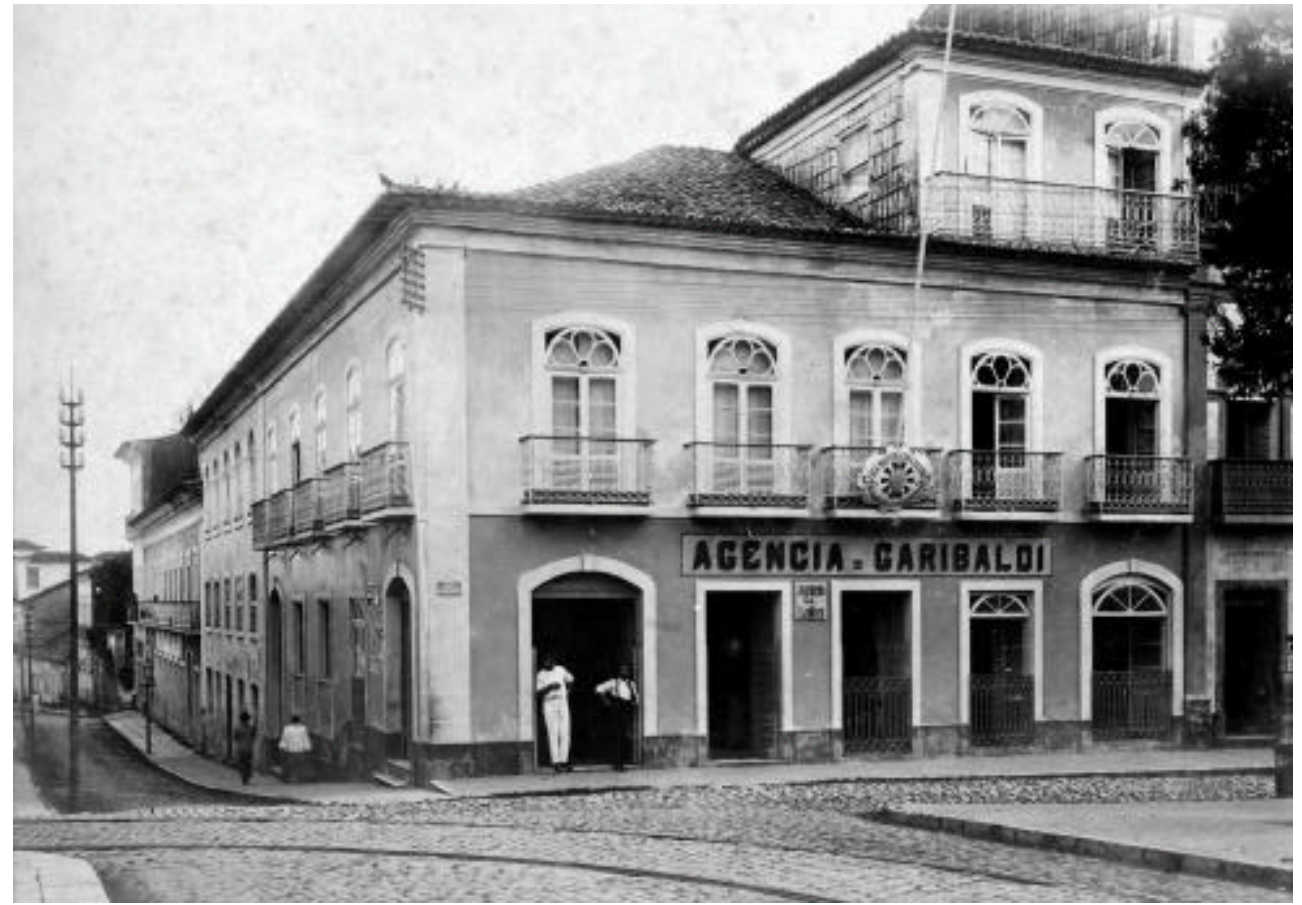

Fotografia 22 - Imóvel sede da Liga Marítima com trilhos em frente. Album..., s.n.p., gelatina/prata, 19,5 x $14 \mathrm{~cm}$. MHAM.

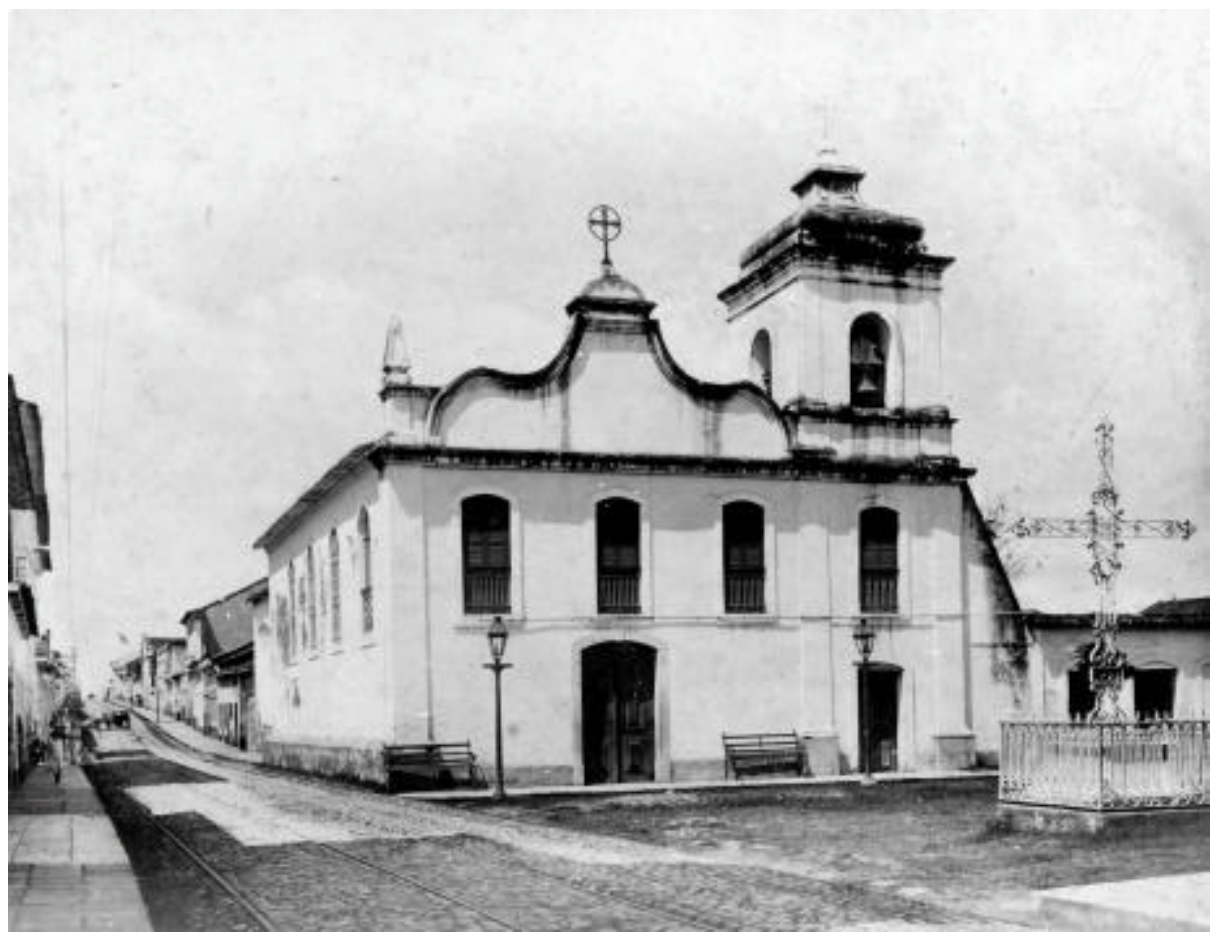

Fotografia 23 - Igreja da Conceição com trilhos ao lado. Album..., s.n.p., gelatina/prata, 15 x $20 \mathrm{~cm}$. MHAM. 


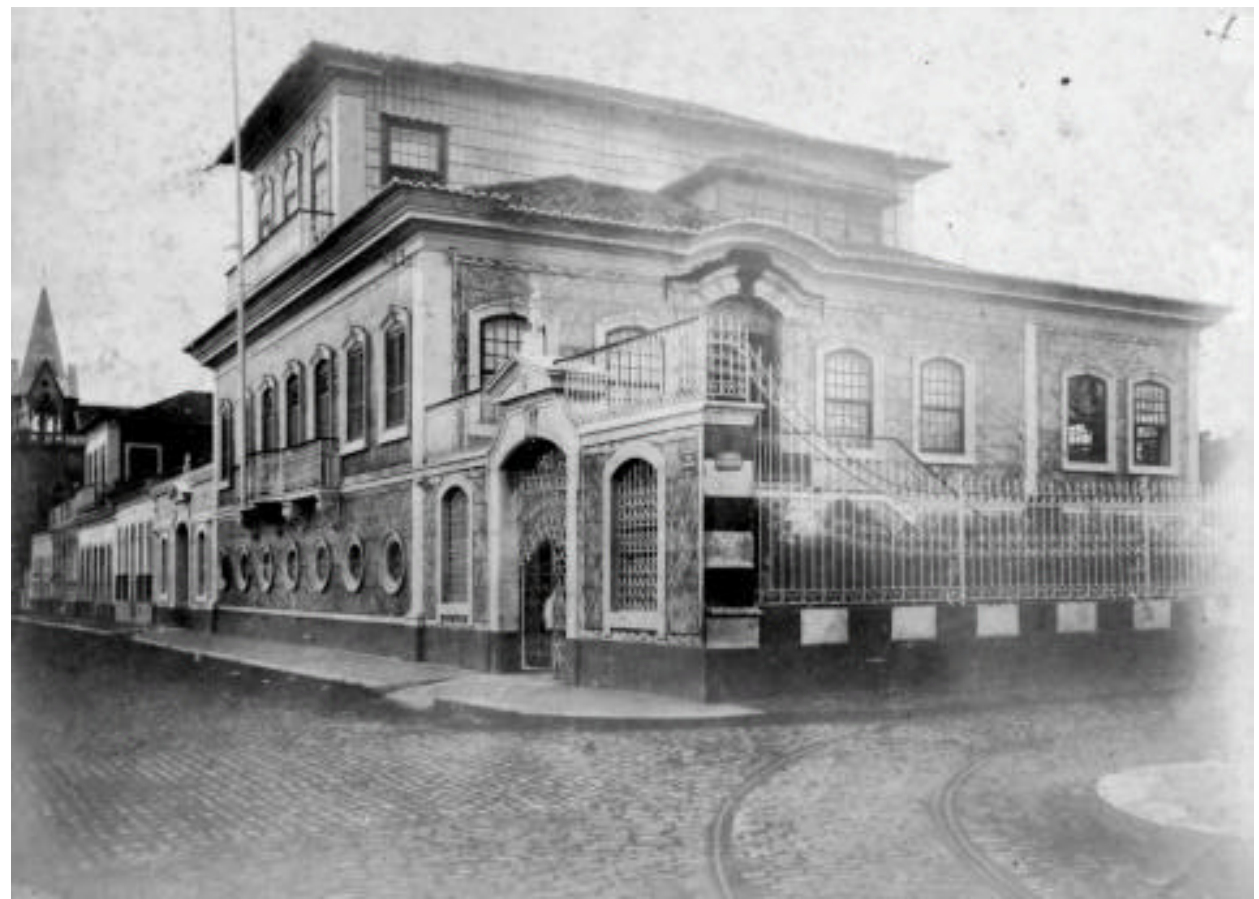

Fotografia 24 - Palacete particular na praça Gonçalves Dias. Album..., s.n.p., gelatina/prata, 14 x $19 \mathrm{~cm}$. MHAM.

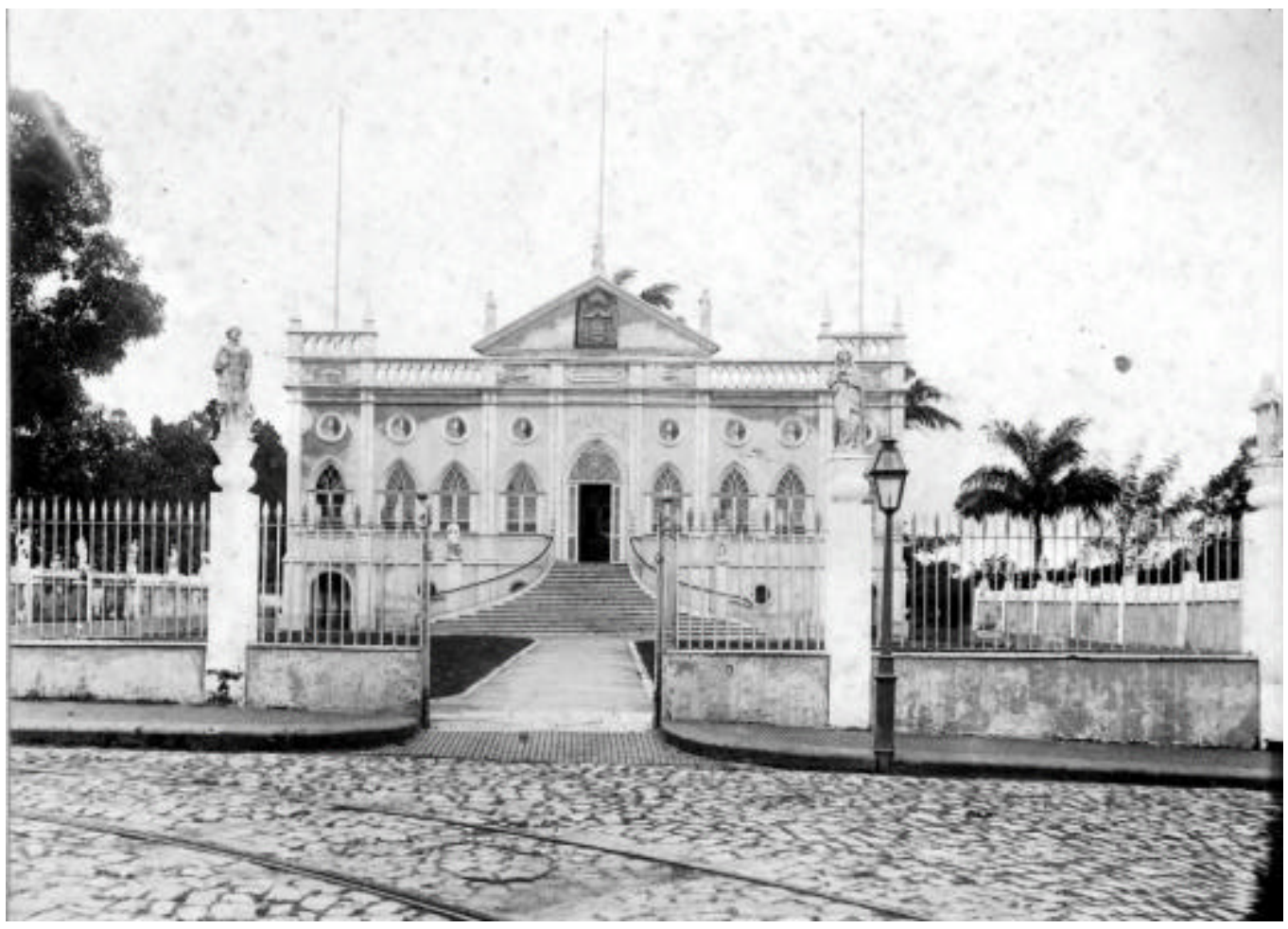

Fotografia 25 - Hospital Portuguez com trilhos em frente. Album..., s.n.p., gelatina/prata, $14,8 \times 19,5 \mathrm{~cm}$. MHAM.

Ao fotografar os imóveis, Gaudêncio Cunha adicionava trechos de ruas com o visível objetivo de evidenciar os trilhos. Evidentemente que sem a presença dos bondes puxados a burros, os únicos que circulavam na área urbana da cidade. O importante e 
necessário eram os trilhos que representavam modernidade. Nessa época, em outros centros urbanos já havia bondes elétricos circulando em trilhos, como é o caso do Rio de Janeiro, desde outubro de $1892^{53}$.

Ao mesmo tempo em que amenizou a característica estreita das ruas de São Luís, o fotógrafo incluiu os trilhos como símbolo do progresso. Os trilhos estão em fotografias da Liga Marítima (Fotografia 22), das igrejas da Sé (Fotografia 39) e Nossa Senhora da Conceição (Fotografia 23), de um palacete particular da Praça Gonçalves Dias (Fotografia 24), do Hospital Portuguez (Fotografia 25), entre outras.

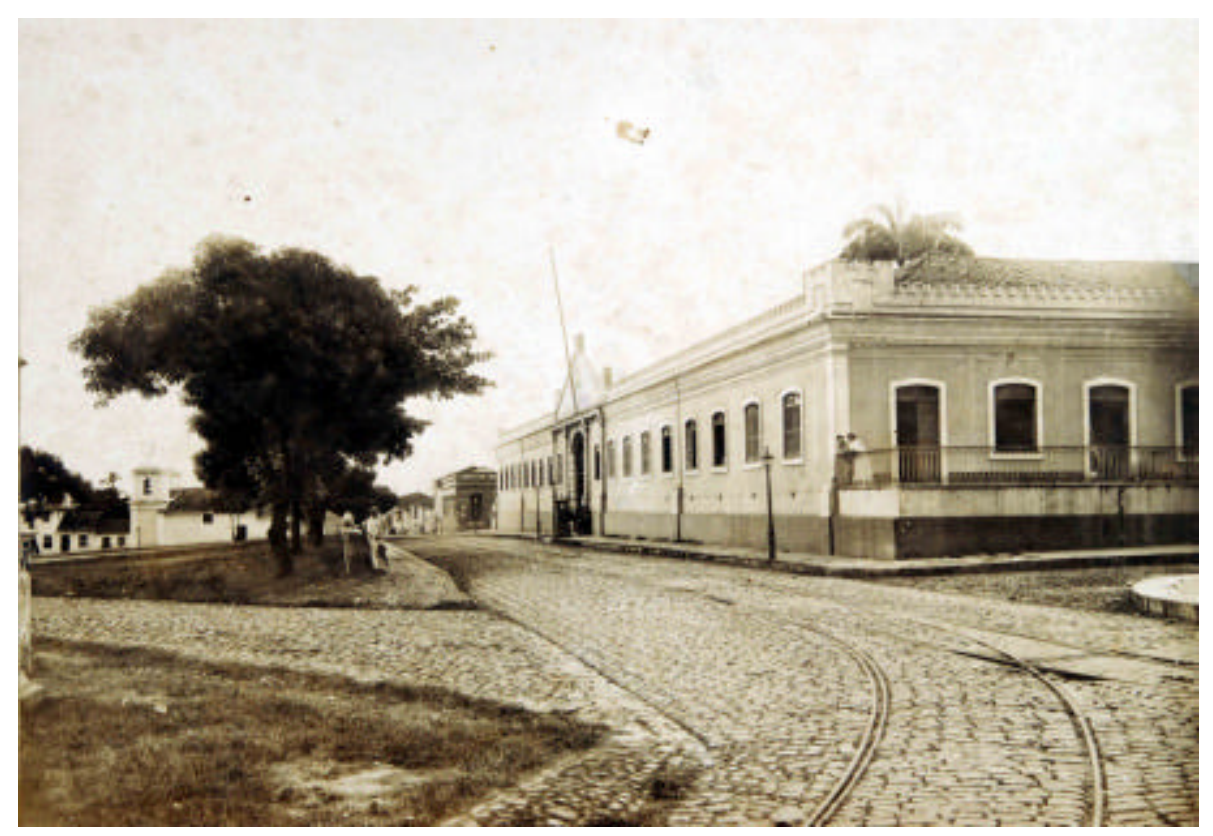

Fotografia 26 - Quartel do $5^{\circ}$ Batalhão de Infantaria na Praça Marechal Deodoro da Fonseca. Album..., s.n.p., gelatina/prata, 28 x 37 cm. MHAM.

Na fotografia do Quartel do $5^{\circ}$ Batalhão de Infantaria (Fotografia 26), os trilhos quase que dividem o privilégio do foco com o imóvel. $\mathrm{O}$ enquadramento, cuidadosamente composto, apresenta ainda, parte da arborização da Praça Marechal Deodoro da Fonseca. Ao fundo, a velha capela de Santaninha pontua distante, como herança de um tempo passado dentro da pretensa modernidade que se pretendia acentuar.

\footnotetext{
${ }^{53}$ PACHECO, Fellipe C. História eclesiástica do Maranhão. São Luís: Departamento de Cultura do Maranhão/Gráfica Lux, 1968. p. 297.
} 


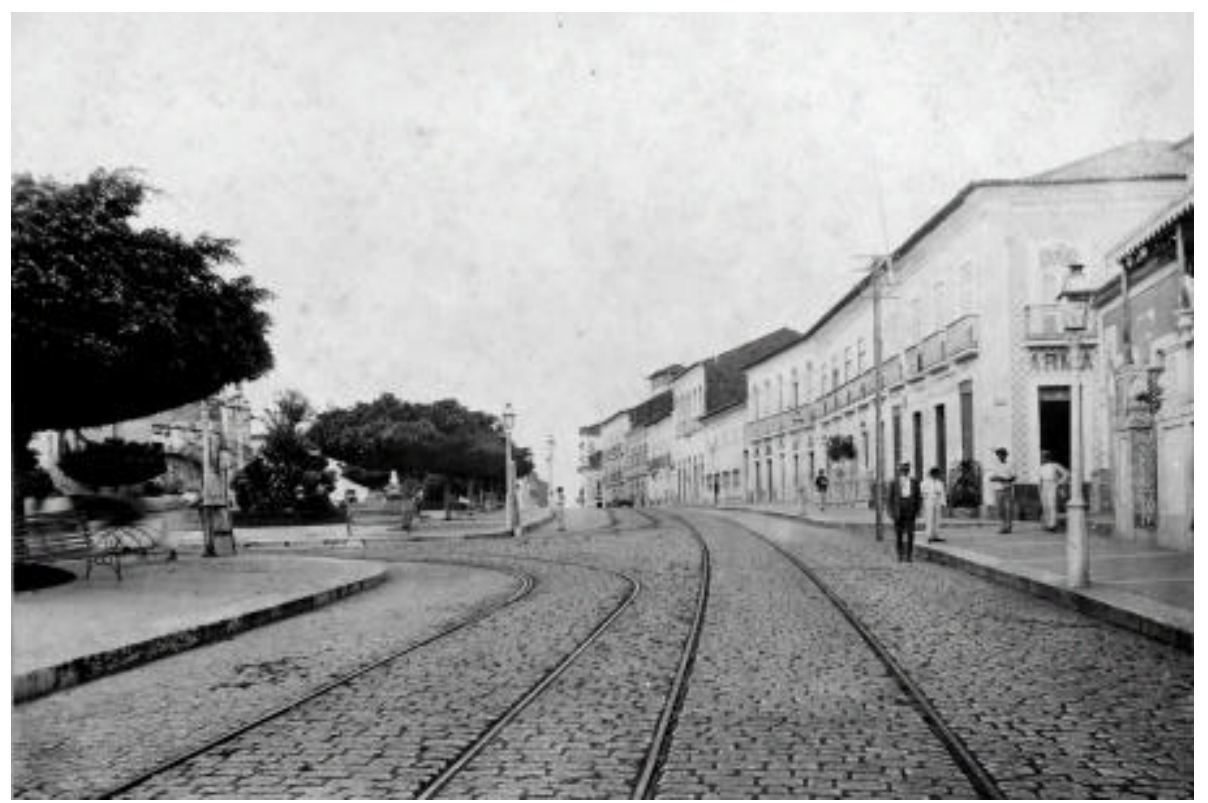

Fotografia 27 - Praça João Lisboa com trilhos em primeiro plano. Album..., s.n.p., gelatina/prata, $16,5 \times 22,5 \mathrm{~cm}$. MHAM.

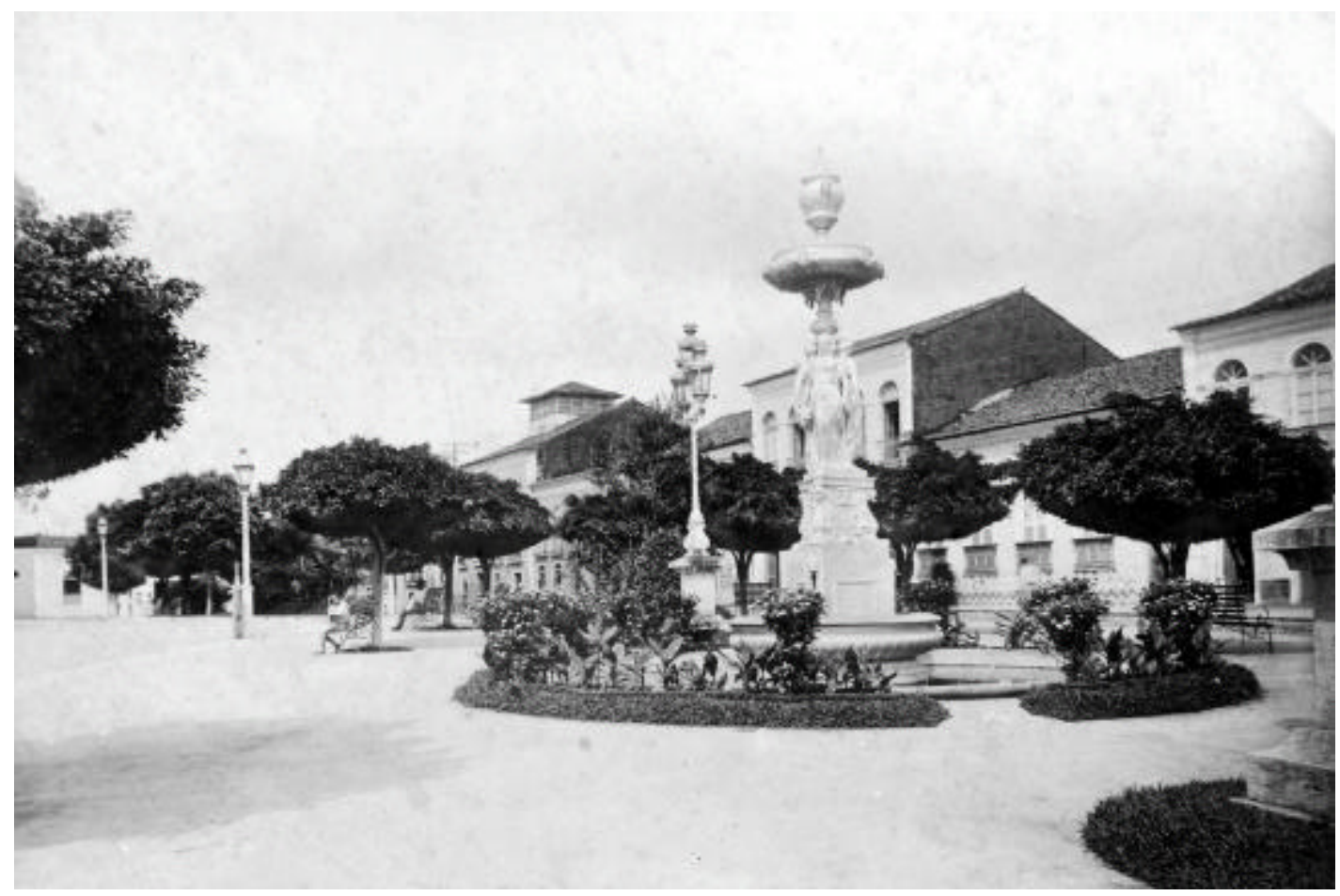

Fotografia 28 - Chafariz na Praça João Lisboa. Album..., s.n.p., gelatina/prata, 16 x $23 \mathrm{~cm}$. MHAM.

Em outras fotografias, os trilhos dos bondes compõem o centro da imagem. A mais significativa é a do Largo do Carmo (Fotografia 27). Nela, os casarões em estilo colonial, com seus beirais, estão bem ao fundo, quase esquecidos. $\mathrm{O}$ importante são as duas 
linhas de bondes que dão ares de modernidade ao lugar. Por outro lado, em outra fotografia da mesma praça, paradoxalmente, o fotógrafo destaca um velho chafariz (Fotografia 28).

O Largo do Carmo/Praça João Lisboa ${ }^{54}$ era uma importante área de celebrações civis e religiosas. O Cortejo em Glorificação a Gonçalves Dias, realizado em 1904, partiu de lá com destino à praça em homenagem ao poeta ${ }^{55}$. Entre as festas religiosas, a de Santa Filomena atraía inúmeros fiéis ${ }^{56}$. Segundo Silva Filho ${ }^{57}$ essa praça era a "menina dos olhos" do governador Benedicto Leite, que morou em suas proximidades.

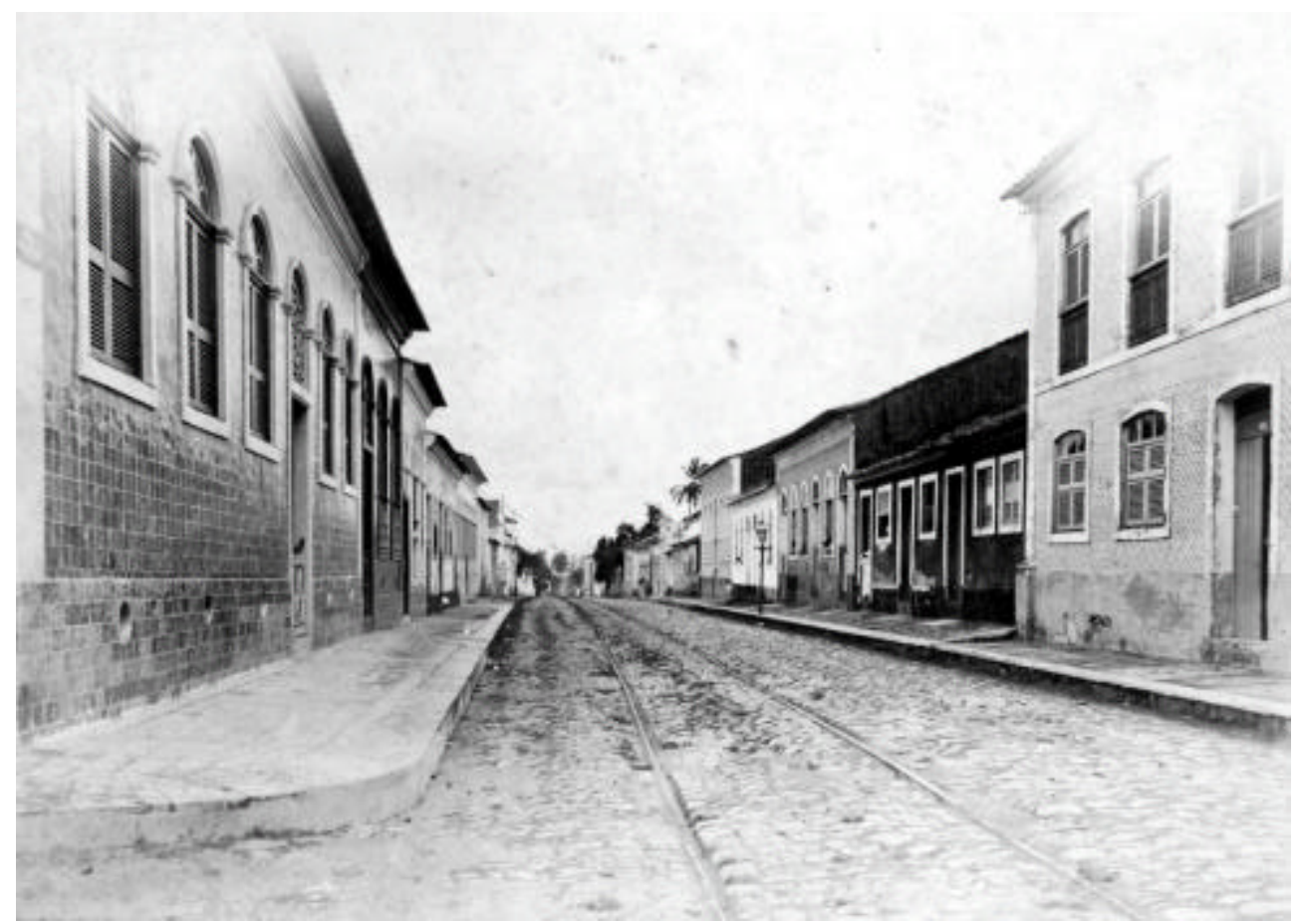

Fotografia 29 - Rua do Passeio Album..., s.n.p., gelatina/prata, 16,4 x 22,5cm. MHAM.

\footnotetext{
${ }^{54}$ Em 1912, o Largo do Carmo passou a se chamar Praça João Lisboa. A estátua do ex-governador maranhense foi inaugurada em 1918. Ver CIDADES HISTÓRICAS INVENTÁRIO E PESQUISAS. SÃO LUÍS . Rio de Janeiro: IPHAN/Senado Federal, 2007, p. 58 .

${ }^{55}$ Revista do Norte, 16.11.1904.

${ }^{56}$ Revista do Norte, 01.10.1902.

${ }^{57}$ SILVA FILHO, José Oliveira da. Olhos de ver: a cidade entre as retóricas do visual e do escrito. Monografia de especialização. (Especialização em História do Maranhão) - CECEN-UEMA, São Luís, 2006.
} 


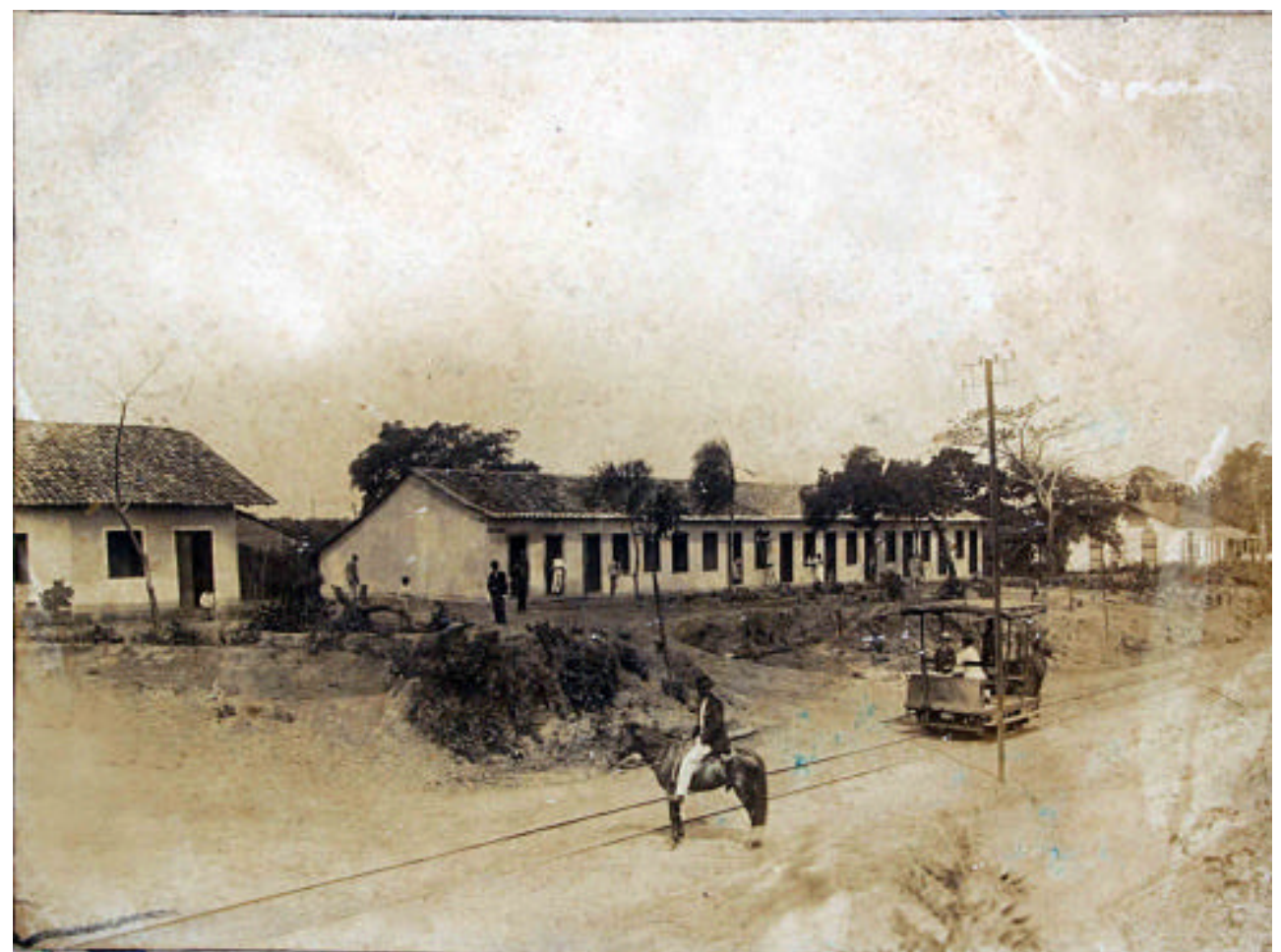

Fotografia 30 - Povoado João Alves e um bonde puxado a burros. Album..., s.n.p., gelatina/prata, 16 x $22 \mathrm{~cm}$. MHAM.

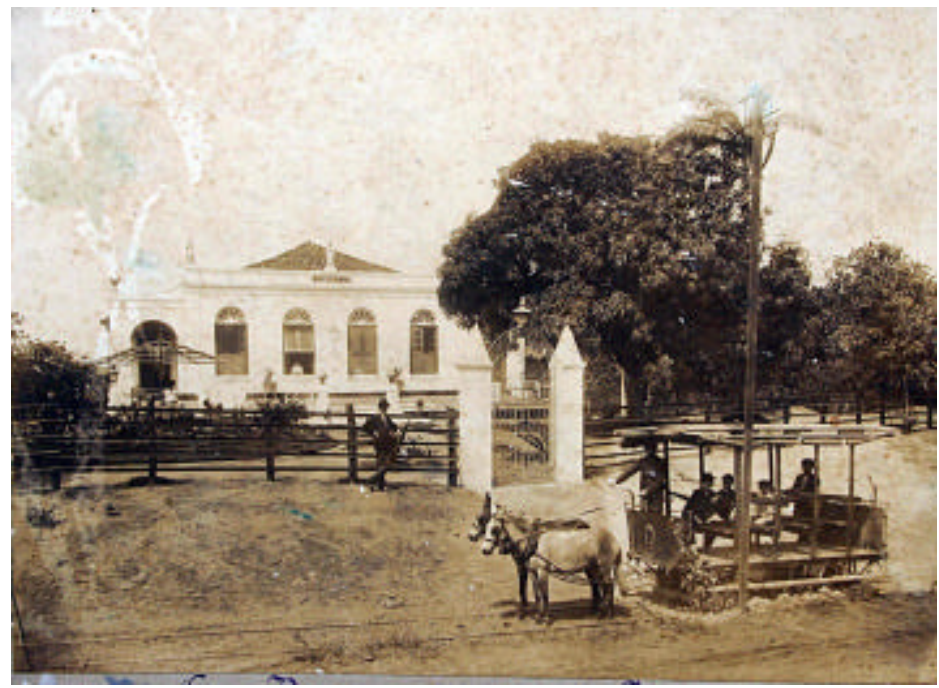

Fotografia 31 - Sítio Britania na estrada do Anil com um bondinho do tipo puxado a burros. Album...,s.n.p., gelatina/prata, 16 x $22 \mathrm{~cm}$. MHAM.

Os trilhos estão no primeiro plano em várias imagens como as das ruas Afonso Pena (Fotografia 4) e Passeio (Fotografia 29). Só que os bondes puxados a burros estão excluídos de todas as fotografias do perímetro urbano. Aparecem nas áreas suburbanas da cidade como Anil (Fotografia 31) e João Alves (Fotografia 30). Nesse tempo, os bondes com 
burrinhos já soavam antigos ${ }^{58}$, ao contrário dos 'trilhos', que atendiam aos anseios da modernidade desejada na época, pois poderia remeter a trilhos de locomotivas a vapor e dos bondes elétricos que rodavam no Brasil, como na São Paulo de $1900^{59}$.

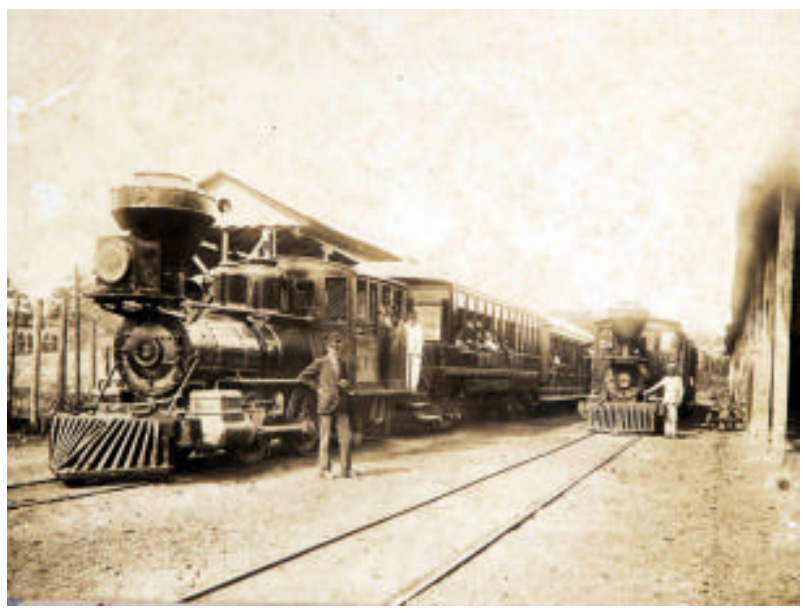

Fotografia 32 - Estação suburbana. Album...,s.n.p., gelatina/prata, 15 x $20 \mathrm{~cm}$. MHAM.

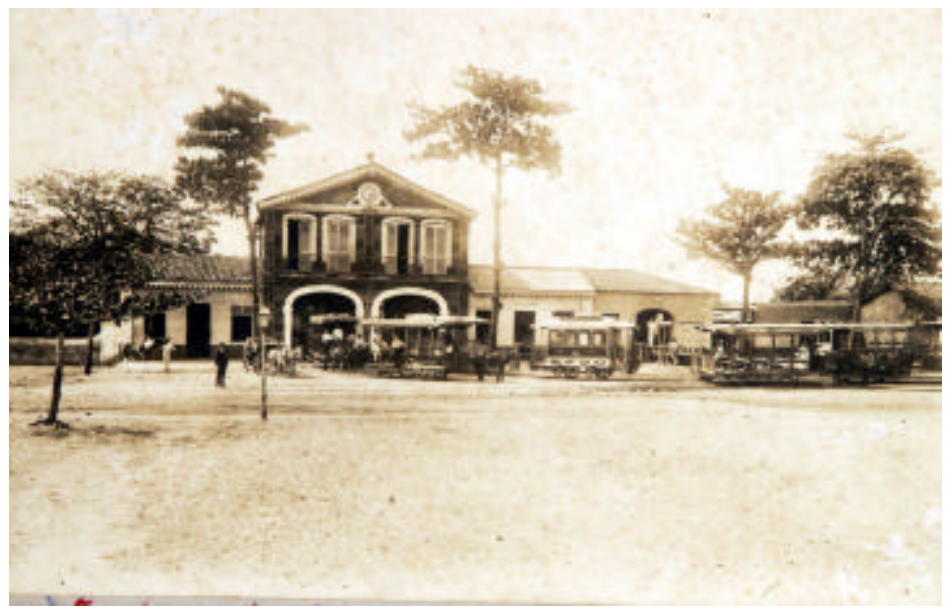

Fotografia 33 - Estação da Companhia Ferro Carril. Album..., s.n.p., gelatina/prata, 16 × $22 \mathrm{~cm}$. MHAM.

\section{A fotografia da Estação Suburbana de São Luís (Fotografia 32) destaca} exatamente outro aspecto moderno ligado a trilhos, que era o das locomotivas a vapor. Essa

\footnotetext{
${ }^{58}$ O bonde puxado a burros começou a funcionar em São Luís no início da década de 1870 , serviços que ficaram sob a responsabilidade da Companhia Ferro-Carril (Ver: PALHANO R. A produção da coisa pública. Serviços públicos e cidadania na Primeira República; a república ludovicense. São Luís: IPES/SIOGE, 1988, p. 155). O bonde elétrico circulou pela primeira vez na cidade 30 de novembro de 1924, depois de um acordo firmado entre o Governo do Maranhão e a Brightman \& Company Inc (Ver: BRAGA, 1991). Na década de 1890, a Companhia Ferro-Carril colocou em funcionamento uma linha de trem puxado a locomotiva a vapor que percorria somente a área suburbana da cidade (Ver: PALHANO, 1988, p. 296-310). A conexão entre as linhas de bondes puxados a burros e a linha de trem a vapor era feita em uma Estação Central localizada nos arrabaldes do perímetro urbano da cidade. A primeira estrada de ferro construída no Maranhão, a Caxias/Flores, é de 1895 e ficava no interior. Interligou a cidade de Caxias a um povoado situado às margens do Rio Parnaíba, em frente a Teresina. A estrada de ferro São Luís/Caxias, só foi inaugurada em março de 1921 (VIVEIROS, 1992, p. 194).

${ }^{59}$ KOSSOY, Boris. São Paulo 1900. Imagens de Guilherme Gaensly. São Paulo: Kosmos/CBPO, 1988b. p. 15.
} 
mesma imagem já havia sido publicada na Revista do Norte, em janeiro de 1906 com a legenda: Linha suburbana da Empreza Ferro Caril. Na Revista, a locomotiva aparece também na altura da nova Ponte do Cutim, com tripulantes e passageiros para dar a ilusão de que estava funcionando.

Nesse tempo, os bondes de tração animal já comprometiam a imagem de modernidade. Daí o orgulho de apresentar a fotografia da Estação Suburbana de São Luís com suas locomotivas no álbum de 1908. Na imagem (fotografia 32) há um homem, bem vestido, em primeiro plano e duas locomotivas. A imagem foi incluída no álbum, também, por causa da nitidez e enquadramentos perfeitos, características que Gaudêncio Cunha sempre almejava. Um detalhe interessante é que a Estação Suburbana aparece na mesma página da Estação Ferro Carril (fotografia 33), com os singelos bondinhos puxados a burro na frente.

Os velhos bondes de tração animal permaneceram em atividade em São Luís até o início da década de 1920, para o desespero das autoridades ${ }^{60}$. "Uma carriola... Desengonçada, sacolejante, suja, indecente, puxada por burricos lazarentos e trôpegos",61, esbravejou o senador maranhense Magalhães de Almeida, em idos da década de 1920. Isso um pouco antes da tardia instalação dos bondes elétricos, em "30 de novembro de 1924" 62.

Um detalhe é que as bitolas dos trilhos de tração animal eram de 1.44 metros. Diferentes das suburbanas que eram de 1.22 metros $^{63}$. Essa minúcia, porém, é irrelevante nas imagens de ruas em que Gaudêncio Cunha acentua os trilhos

\footnotetext{
${ }^{60} \mathrm{Na}$ passagem do século XIX para o XX existiam três linhas com bondes de tração animal, sendo duas totalmente dentro da área urbana e uma que ligava a área urbana à suburbana. Havia outras três linhas suburbanas, com tração que percorriam a área do Caminho Grande até a povoação Anil, com parada em uma estação central. PALHANO, 1988, p. 304-306.

${ }^{61}$ BRAGA, Pedro. O velho bonde. São Luís: Jornal O Estado do Maranhão, Caderno Alternativo, 20.4.1991

${ }^{62}$ Ibid.

${ }^{63}$ PALHANO. Raimundo. A produção da coisa pública. Serviços públicos e cidadania na Primeira República: a república ludovicense. São Luís IPES/SIOGE, 1988. p. 309.
} 


\subsubsection{Os postes diferenciados}

No início do século XX, conforme explicação de Luís Phelipe Andrès ${ }^{64}$, havia dois tipos de postes em São Luís: os mais baixos que sustentavam as luzes de iluminação a gás ${ }^{65}$ e os mais altos, de madeira, que eram utilizados para segurar os fios de telefonia ou telégrafos ${ }^{66}$. Os mais altos eram fincados em lugares mais amplos como a Praça João Lisboa ou trechos de ruas próximos de lugares largos. Os fios sustentados pelos postes de madeira se interligavam aos suportes fincados em fachadas de imóveis das ruas estreitas. Os dois tipos de postes podem ser vistos na Rua da Paz (Fotografia 34), em primeiro plano da fotografia legendada como sendo da Igreja de São João.

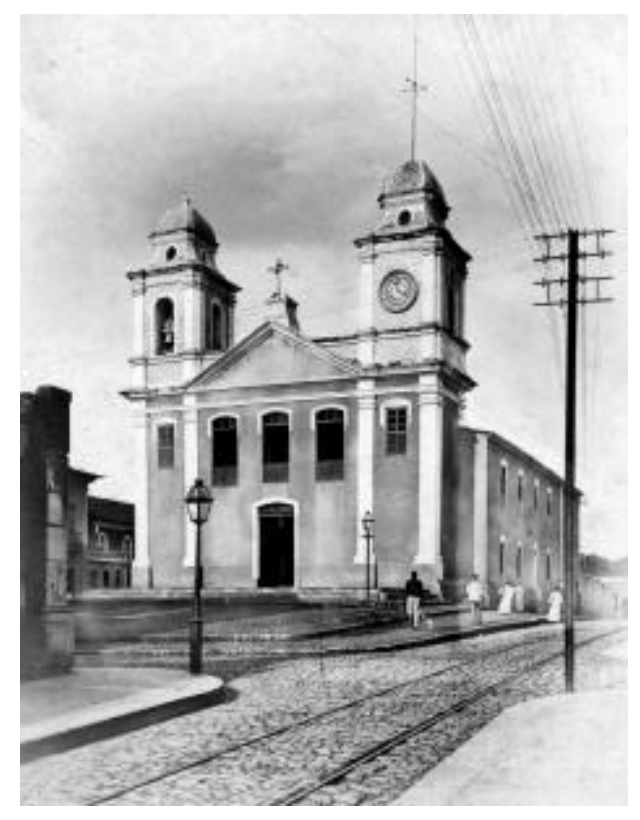

Fotografia 34 - Igreja São João e trecho da Rua da Paz ao lado, com trilhos e dois modelos de postes. Album..., s.n.p., gelatina/prata, 18 x 14,5cm, MHAM. .

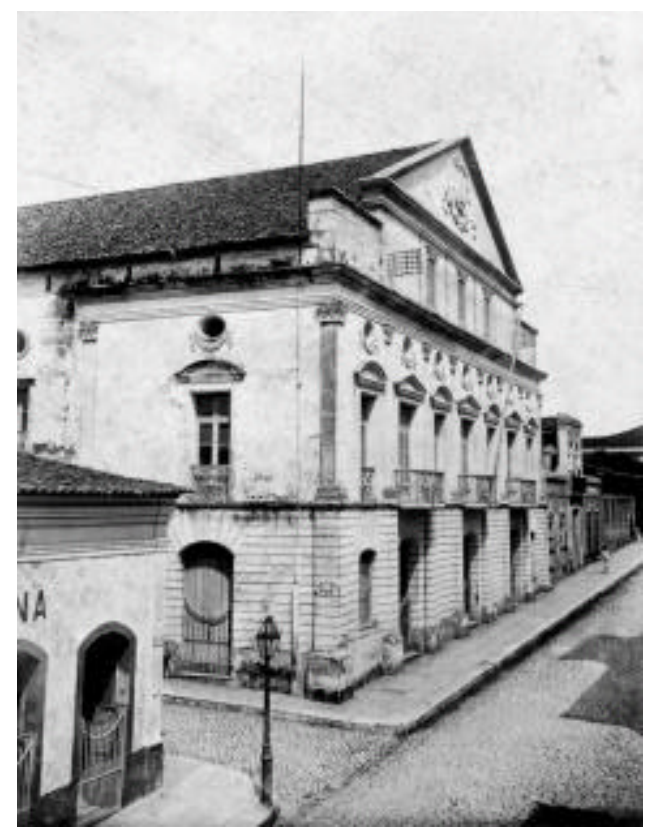

Fotografia 35 - Teatro São Luiz com os suportes para fios de telefone ou de telegrafo no alto da fachada. Album..., s.n.p., gelatina/prata, $15 \times 20 \mathrm{~cm}$. MHAN.

\footnotetext{
${ }^{64}$ Depoimento de Luiz Phelipe Andrès concedido a José Reinaldo Castro Martins em 25.5.2007, no Estaleiro Escola (Sítio Tamancão), em São Luís. O engenheiro civil mineiro (viveu alguns anos no Rio de janeiro) Luiz Phelipe de Carvalho Castro que vive em São Luís desde o final da década de 1970. Ele e sua equipe utilizaram fotografias que compõem o álbum de 1908 para revitalizar paisagens do centro histórico de São Luís.

${ }^{65}$ Segundo Meireles (Ver: 2001, p. 250), o serviço de iluminação de São Luís foi inaugurado em São Luís em 1863.

${ }^{66}$ O telégrafo terrestre foi instalado em São Luís em dezembro de 1884 (Ver: Pacheco, 1922, p.41) O telefone chegou na década de 1880, mas a rede só foi instalada em 1890 (Ver; MELO, Luiz. Primórdios da telefonia em São Luís e Belém. São Luís/Academia Maranhense de Letras/Alumar/Lithograf, 1999). Um serviço de energia elétrica chegou a funcionar em São Luís em setembro de 1918, mas somente na década de 1920 a iluminação elétrica foi definitivamente implantada (Ver: Palhano, 1988, p. 293).
} 
Os suportes para fios de telefonia ou telégrafo foram colocados em fachadas de edificações de ruas estreitas como a 28 de Julho (Fotografia 58) Afonso Pena (Fotografia 4) e no prédio do Teatro São Luiz (Fotografia 35), na Rua do Sol. Nessas ruas, era inviável colocar postes alto de madeira, por causa, principalmente de questões ligadas à segurança. Os fios corriam entre os suportes colocados nas fachadas e o dos postes de madeiras que foram fincados em trechos mais abertos da cidade.

Essa foi a estratégia encontrada para a inclusão de fios que conduziam serviços modernos nas ruas de casarões colônias, antigas e estreitas de São Luís. A diacronia montada permitiu que o novo se agregasse ao antigo, criando uma imagem de perfil aparentemente harmônico, mas que apresenta diferenças temporais.

O fotógrafo português Felipe Fidanza que trabalhou nessa mesma época em Belém e é o provável professor de Cunha, também destacou trilhos de bondes em fotografias de paisagens de Belém ${ }^{67}$. Teve menos dificuldades para fazer esses enquadramentos do que Cunha, pois havia mais vias largas em Belém nessa época.

As ruas estreitas dificultaram até o trabalho de Gaudêncio Cunha pela cidade. A imagem da Fachada do Teatro São Luiz (Fotografia 35) teve de ser feita meio de lado por causa da pequena largura da Rua do Sol. O fotógrafo ficou impossibilitado de fazer uma tomada de toda a fachada se ficasse em frente ao prédio. O mesmo aconteceu com a Photographia União (Fotografia 15), também, situado na Rua do Sol. (Fotografia 5).

Apesar das ruas estreitas, São Luís foi uma cidade projetada pelos portugueses, em uma fase inicial, logo depois da expulsão dos franceses, no século XVII. Salvo alguns trechos, as ruas são retas e enquadradas.

[...] o traçado da cidade apresenta a constância dos quarteirões quadrados e as ruas quase todas de largura constante, orientadas de acordo com os pontos cardeais, mostrando uma regularidade marcante, quebrada, às vezes por alguma adaptação que se fazia necessária ao terreno $[\ldots]^{68}$

Dentro da concepção originariamente projetada de São Luís pelo engenheiro militar Francisco Frias de Mesquita, no século XVII, dois aspectos abordados por Tais Zenkner $^{69}$ chamaram a atenção. O primeiro é que as igrejas conseguiram, de alguma forma, imprimir uma dinâmica própria na urbanidade da cidade. A outra questão levantada pela

\footnotetext{
${ }^{67}$ PEREIRA, Rosa Claudia C. Paisagens urbanas: fotografia e modernidade na Cidade de Belém (1846-1908). Dissertação (Mestrado em História) - DEHIS-UFPA, Belém, 2006. p.165.

68 ZENKNER, Taís. O modo de fazer cidades portuguesas: as Leis das Índias e a forma da cidade de São Luís. In: PONTUAL; CARNEIRO, A. R. S. História e paisagem. Ensaio urbanístico do Recife e de São Luís. Recife: Bagaço, 2005, p. 316.

69 Ibid., p. 313.
} 
autora é a de que a sua expansão partiu de um centro cívico, como ela chama ${ }^{70}$ à área do Largo do Palácio/Avenida Maranhense.

O encadeamento das fotografias nas páginas do Album do Maranhão em 1908, ao que tudo indica, obedece a uma seqüência semelhante a da expansão da cidade a partir desse centro cívico em direção ao interior da Ilha de São Luís. As primeiras fotografias são da área próxima ao Palácio do Governo e do porto como o Cais da Sagração. Em seguida vem a Avenida Maranhense (antigo Largo do Palácio e atual Avenida Dom Pedro II) e seus prédios como o Palácio do Governo, erguido ao lado do porto.

Depois vêm as principais praças, as ruas bem como os imóveis (fachadas e alguns ambientes internos) de São Luís, até chegar às áreas rurais arrabaldes da cidade. Por fim, seguem as imagens das cidades mais important es do Maranhão na época.

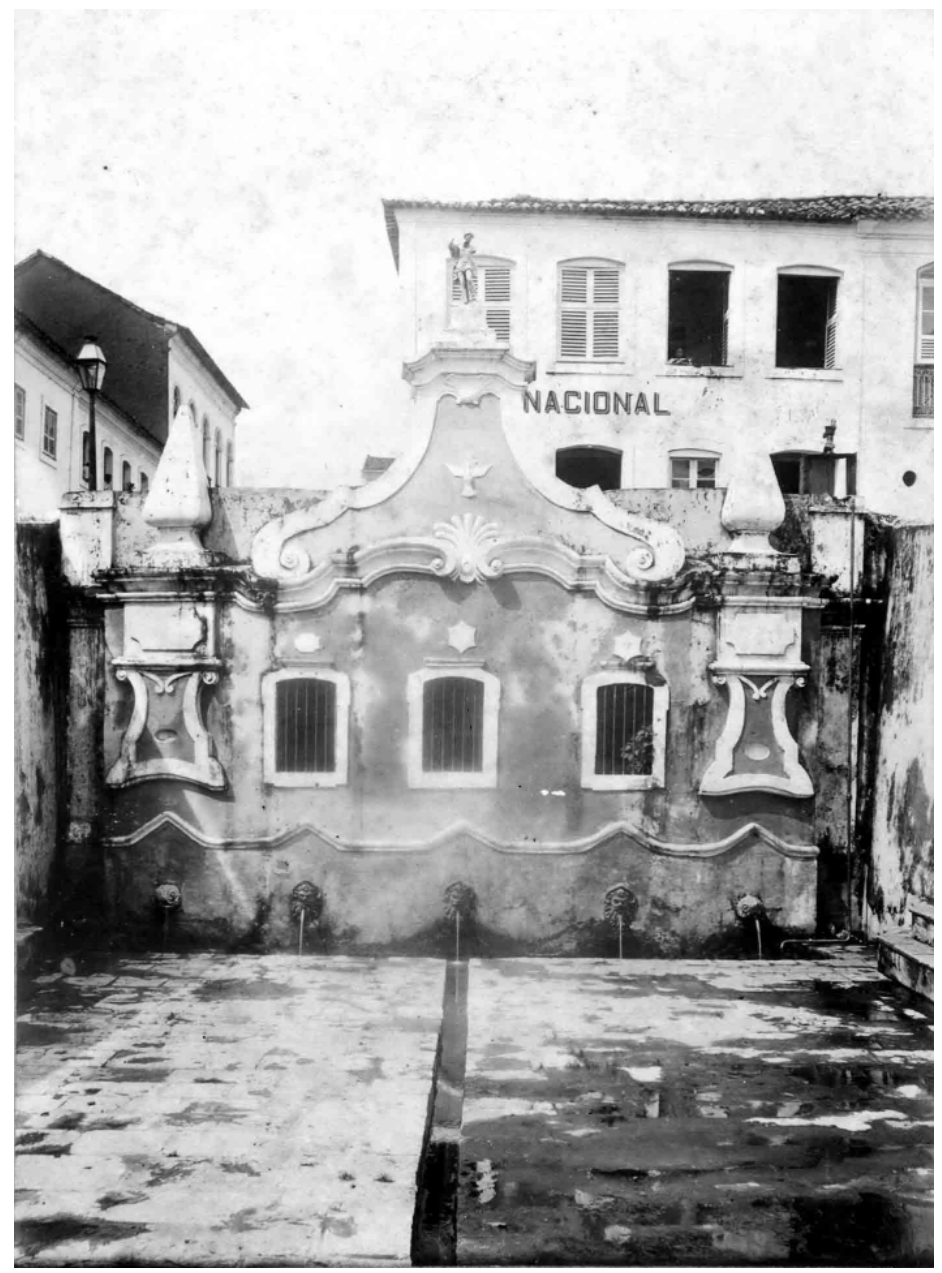

Fotografia 36 - Fonte do Ribeiro. Album..., s.n.p., gelatina/prata, 15 x $20 \mathrm{~cm}$. MHAM.

\footnotetext{
${ }^{70}$ ZENKNER, Tais. O modo de fazer cidades portuguesas: as Leis das Índias e a forma da cidade de São Luís. In: PONTUAL, V; CARNEIRO, A. R. S. História e Paisagem. Ensaio urbanístico do Recife e de São Luís. Recife: Bagaço, 2005 , p. 316.
} 
Os moinhos das velhas indústrias de Paris, segundo Le Goff ${ }^{71}$ resistiram ao tempo. A capital francesa só prevaleceu como centro do poder com a Revolução Francesa. A sua desruralização, segundo o autor, é um fenômeno do século $\mathrm{XIX}^{72}$. Em São Luís, os chafarizes do tempo do Império (Fotografias 14 e 28) resistiram ao tempo, assim como as fontes (Fotografia 36) que existem até hoje na cidade.

\subsubsection{Avenida Maranhense}

O centro cívico citado por Tais $Z_{\text {Znkner }}^{73}$ é configurado como Avenida Maranhense no tempo de Gaudêncio Cunha. No local, encontravam-se o Palácio do Governo, a Catedral da Sé, o Palácio Episcopal e a Intendência Municipal. É o mesmo Largo do Palácio de 1846, onde ficava o imóvel em que Charles Fredricks instalou os serviços de daguerreótipo.

Apesar de seu aspecto amplo, com possibilidades de ser agradável aos olhos de viajantes modernos como Annibal Amorim ${ }^{74}$, a Avenida Maranhense é configurada de forma semelhante ao retângulo de cidade medieval. É como se fosse uma "cidadela" que reúne os poderes temporais e espirituais. A sua principal saída é um ponto de passagem, estreito, que a liga com a Praça Benedicto Leite (Fotografia 39). Depois a cidade se estende até outra abertura, que é o Largo do Carmo/Praça João Lisboa. Ainda há uma terceira grande abertura, a Praça Marechal Deodoro, o antigo Largo do Quartel.

\footnotetext{
${ }^{71}$ LE GOFF, Jacques. Por amor às cidades. São Paulo: UNESP, 1988, p. 143.

${ }^{72}$ No livro Por Amor às Cidades (Ver: LE GOFF, Jacques, 1988), sobre as origem e evolução das cidades ocidentais, Jacques Le Goff, 'desmonta' iconogr afias medievais e contemporâneas - pinturas e fotografias, sobretudo, unindo imagens e textos, nas suas investigações.

${ }^{73}$ ZENKNER, Tais. O modo de fazer cidades portuguesas: as Leis das Índias e a forma da cidade de São Luís. In: PONTUAL, V; CARNEIRO, A. R. S. História e Paisagem. Ensaio urbanístico do Recife e de São Luís. Recife: Bagaço, 2005 , p. 316.

${ }^{74}$ AMORIM, Aníbal. Viagem pelo Brasil. Do Rio ao Acre - Aspectos da Amazônia - Do Rio a Matto Grosso. Rio de Janeiro: Livraria Garnier, 1917, p. 8.
} 


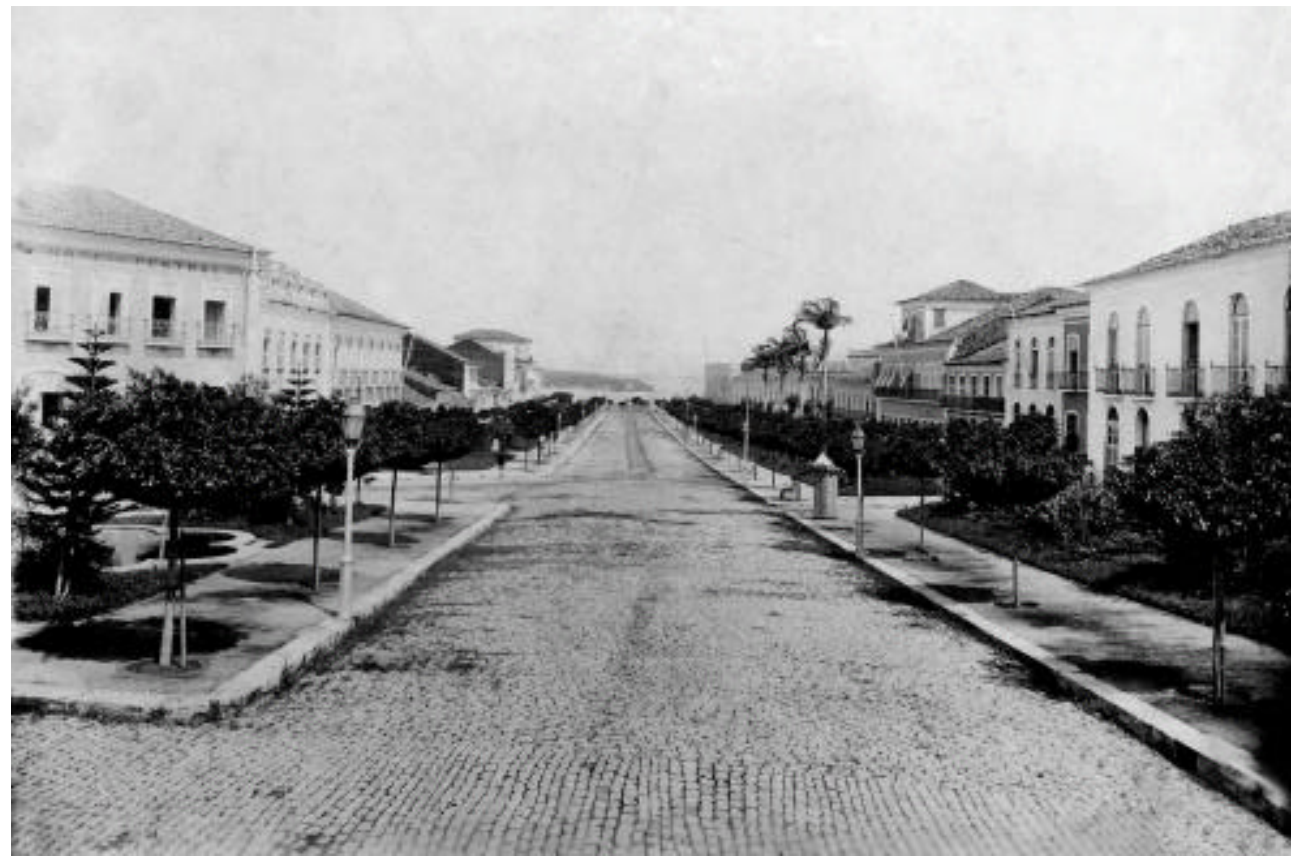

Fotografia 37 - Avenida Maranhense vista a partir do Palácio Episcopal em direção a rampa de acesso ao porto. Album..., s.n.p.,gelatina/prata, 29 x $38 \mathrm{~cm}$. MHAM.

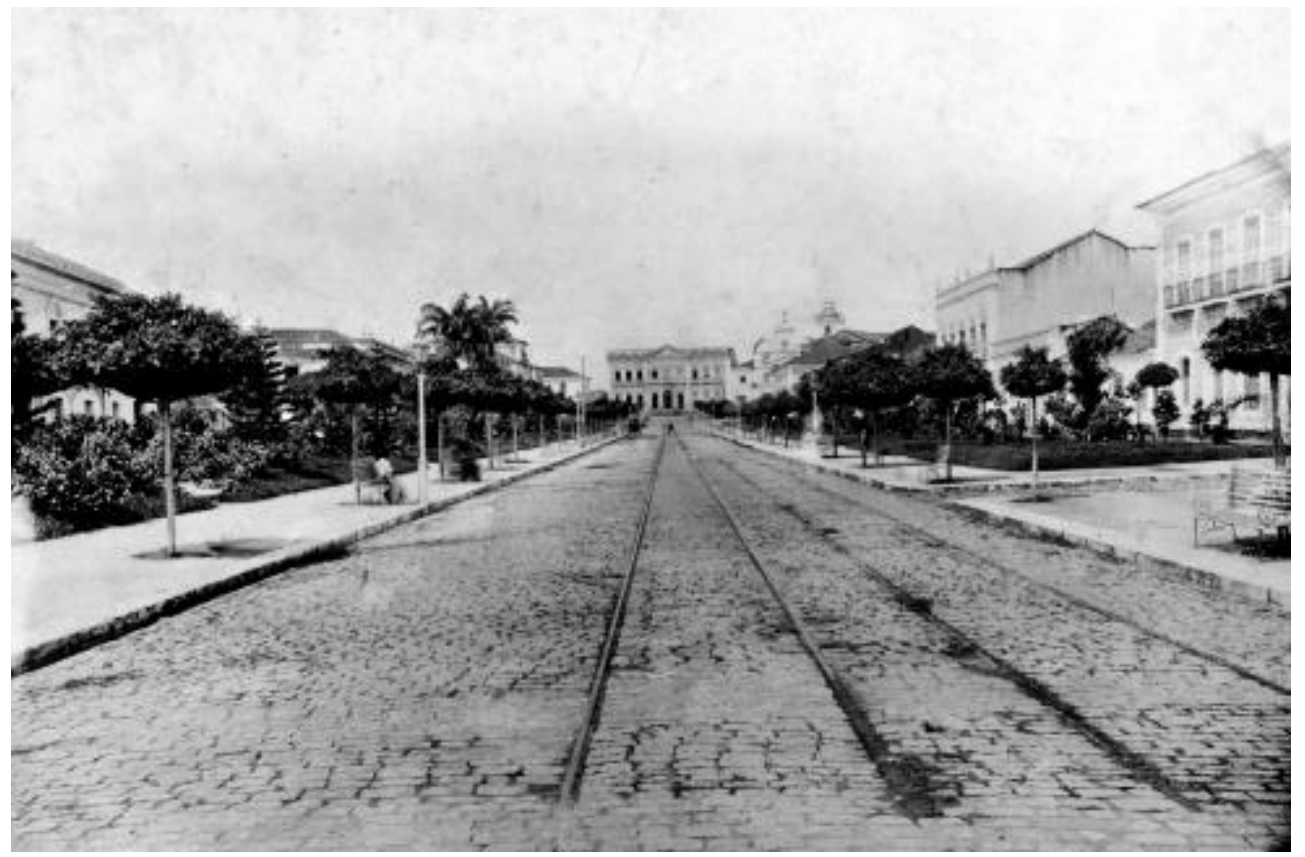

Fotografia 38 - Avenida Maranhense vista a partir das proximidades do acesso à rampa do porto, com o Palácio Episcopal ao fundo. Album..., s.n.p.,gelatina/prata, 29 x $38 \mathrm{~cm}$. MHAM. 


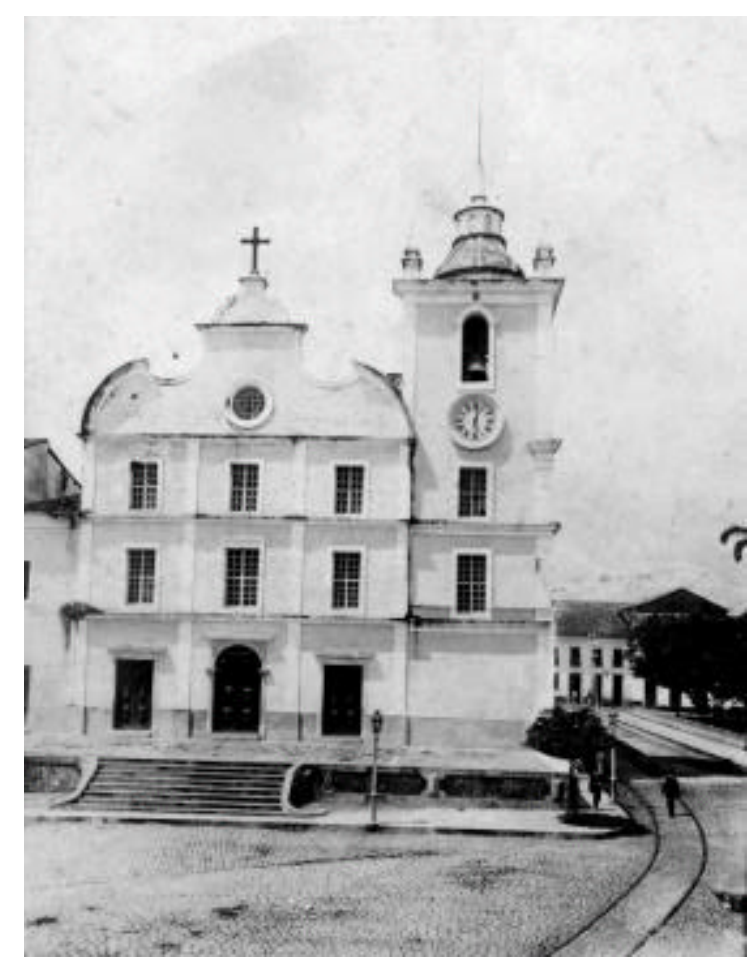

Fotografia 39 - Catedral da Sé, com a passagem da Avenida Maranhense para a Praça Benedicto Leite, ao lado. Album..., s.n.p. gelatina/prata, 16,5 x $23,8 \mathrm{~cm}$.

A Avenida Maranhense (Fotografias 37 e 38) constituiu-se no palco privilegiado pelos poderes institucionalizados para a realização das mais importantes celebrações populares, cívicas e religiosas de São Luís. Por outro lado, nas dependências internas das edificações localizadas nessa via, como Palácio do Governo, o poder também celebra, mas sem a presença da população.

Nos salões, jardins e corredores do Palácio do Governo o poder encontra-se apartado dos transeuntes. Nesses espaços, silenciar, distante dos comandados, para, assim poder existir, como atenta Balandier ${ }^{75}$.

Mas, são as celebrações populares realizadas na Avenida Maranhense no início do século XX que atraíram um grande número de pessoas. O lugar ficou repleto de pessoas em cinco de julho de 1901, na recepção de chegada do novo bispo, Antonio Xisto Albano ${ }^{76}$. A festa pela chegada do religioso, segundo Pacheco ${ }^{77}$ foi grandiosa. Contudo, depois de quatro anos à frente do bispado maranhense, Xisto Albano terminou deixando o cargo desacreditado.

Um dos fatores que contribuiu para denegrir a imagem do bispo foi o fato de ele ter elevado os valores das taxas de serviços oferecidos pela igreja como a concessão das

\footnotetext{
${ }^{75}$ BALANDIER, Georges. O poder em cena. Coimbra: Minerva, 1999.

${ }^{76}$ Diário do Maranhão dos dias 4, 5 e 6.7.1901.

${ }^{77}$ PACHECO, Fellipe C. História eclesiástica do Maranhão. São Luís: Departamento de Cultura do Maranhão/Gráfica Lux, 1968. p.479.
} 
crismas $^{78}$. Só que foi justamente com os recursos arrecadados que ele conseguiu aplicar 140 contos de réis na reforma do Palácio Episcopal ou Palácio do Bispo (Fotografia 40), uma das edificações mais imponentes da Avenida Maranhense.

O afluxo de pessoas foi memorável na Avenida Maranhense nas recepções ao presidente eleito do Brasil Affonso Penna a São Luís, de 5 a 8 de julho de 1906. Penna, acompanhado do governador Benedito Leite, entrou com pompa na avenida logo depois do desembarque na rampa do porto.

O presidente eleito do Brasil se hospedou no Palácio Episcopal ${ }^{79}$ que se achava totalmente reformado com recursos arrecadados por Dom Xisto. Foi cedido pelo monsenhor Vicente Galvão, que havia substituído Dom Xisto. O presidente se hospedou no Palácio Episcopal por que o Palácio do Governo, que seria o mais adequado para acolher o presidente do Brasil, encontrava-se em péssimo estado de conservação. Chegou a ser condenado pela repartição de hygiene ${ }^{80}$.

$\mathrm{Na}$ noite do dia 5, entre 8 e 9 da noite, Penna, Leite e demais autoridades percorreram a pé a Avenida Maranhense que "[...] apresentava soberba ornamentação, estando feericamente illuminada a giorno [...]"81. Uma celebração cívica aberta aos transeuntes. No restante da cidade, nessa noite, eles utilizaram viaturas. Em outros dias, Penna chegou a andar a pé pela Rua Portugal (na área comercial da cidade), como mostra uma fotografia publicada na Revista do Norte ${ }^{82}$ e talvez até por outras vias da cidade, mas sem a pompa celebrante da noite de sua chegada, na Avenida Maranhense.

Em momentos importantes da história política do Maranhão, a Avenida Maranhense foi o palco privilegiado de manifestações e celebrações populares. Por outro lado, confabulações silenciosas aconteceram com freqüência nos ambientes internos de suas edificações.

No dia 18 de novembro de 1889, logo depois de implantado o sistema republicano no Brasil, o poder, silenciosamente instalado dentro do Palácio do Governo, contornava a situação de instabilidade vivida naquele instante, instaurando uma Junta Provisória no comando do Maranhão. Interessante o incômodo que o historiador Jerônimo de Viveiros ${ }^{83}$ sentiu por não ter havido nesse momento qualquer manifestação popular no Largo do Governo

\footnotetext{
${ }^{78}$ PACHECO, Fellipe C. História eclesiástica do Maranhão. São Luís: Departamento de Cultura do Maranhão/Gráfica Lux, 1968. p. 467.

${ }^{79}$ Revista do Norte, julho de 1906.

${ }^{80}$ MARANHÃO. Mensagem que o Exm ${ }^{\circ}$ Sr. Governador Benedicto Pereira Leite apresentou ao Congresso Legislativo do

Maranhão, em 7 de fevereiro de 1907. Imprensa Official do Maranhão, 1907.

${ }^{81}$ Revista do Norte, julho de 1906.

${ }^{82}$ Revista do Norte, julho de 1906.

${ }^{83}$ VIVEIROS, Jerônimo de. Benedito Leite. Um verdadeiro republicano. Rio de Janeiro: Taveira, 1957. p. 20.
} 
(Avenida Maranhense), nem mesmo de curiosidade. "Na praça, em frente ao Palácio, nenhum popular, curioso, bisbilhotando o acontecimento. A própria classe estudantil, que formava a massa do Clube Republicano não festejou a vitória. Só a 22 promoveu a sua passeata» ${ }^{\circledR 4}$.

A indiferença da sociedade maranhense frente ao regime republicano durou muito pouco. Algum tempo depois, a smbologia usada para legitimar a República ${ }^{85}$ ajudou a estreitar os laços da população com o novo regime. Nos primeiros anos da década de 1890, o fotógrafo Rodolpho Vasconcellos já fotografava o cortejo militar de 15 de Novembro na Avenida Maranhense em comemoração à República ${ }^{86}$.

Ao contrário das ruas estreitas da cidade, o Largo do Palácio foi transformado na arborizada e larga Avenida Maranhense. Agradou ao viajante Annibal Amorim ${ }^{87}$ que esteve em 1909 em São Luís causando-lhe uma boa impressão: "Uma bella via pública, bem construída e cuidadosamente arborizada" ${ }^{" 88}$.

Duas fotografias dessa via estão entre as primeiras e as maiores do álbum. Cada uma ocupa toda uma página. Uma só não bastou para apresentá-la. Gaudêncio Cunha colocou a imagem da avenida vista de dois ângulos assimétricos. Uma a partir da rampa que conduzia para o porto, tendo o Palácio Episcopal ao fundo (Fotografia 38). A segunda, ao contrário, é uma tomada a partir do Palácio Episcopal (Fotografia 37).

Apesar de ampla e arborizada, a Avenida Maranhense é ladeada por antigas edificações, como a Catedral (Fotografia 39) que teve, posteriormente, a sua fachada quase que totalmente alterada. Lá estão ainda parte do imóvel do Hotel Central (Fotografia 50) e a Intendência Municipal (Fotografia 42). O Palácio Episcopal (Fotografia 40), nesse tempo, encontrava-se no auge de sua beleza devido à reforma conduzida por Dom Xisto ${ }^{89}$.

Os modernos trilhos aparecem nas fotografias. Só os trilhos, pois, nessa paisagem, não cabia a imagem dos bondes de tração animal que já eram considerados ultrapassados. Os trilhos incrementavam o velho poder com novidades dos tempos modernos. É o antigo poder se apropriando, protegendo e vigiando a modernidade.

Charles Fredricks, com seu inovador daguerreótipo, quando se instalou, em 1846, em um imóvel do Largo do Palácio, é como se estivesse recebendo o referendo e, ao mesmo

\footnotetext{
${ }^{84}$ VIVEIROS, Jerônimo de. Benedito Leite. Um verdadeiro republicano. Rio de Janeiro: Taveira, 1957. p. 20.

${ }^{85}$ CARVALHO, José Murilo de. A formação das almas. São Paulo: Companhia das Letras, 2002.

${ }^{86}$ KOSSOY, Boris. Dicionário histórico-fotográfico brasileiro: fotógrafos e ofício da fotografia (1833-1910). São Paulo: Instituto Moreira Salles, 2002. p. 313. A fotografia ainda não foi localizada ou identificada

${ }^{87}$ AMORIM, Aníbal. Viagem pelo Brasil. Do Rio ao Acre - Aspectos da Amazônia - Do Rio a Matto Grosso. Rio de Janeiro: Livraria Garnier, 1917.

${ }^{88}$ Ibid., p. 113.

${ }^{89}$ PACHECO, Fellipe C. História eclesiástica do Maranhão. São Luís: Departamento de Cultura do Maranhão/Gráfica Lux, 1968. p. 466-468.
} 
tempo, atualizando o poder com novidades. Outro ícone da modernidade, a sede do Telegrapho Nacional (Fotografia 16) também estava na Avenida Maranhense.

\subsubsection{Ambientes internos}

Ao final de uma das laterais da Avenida Maranhense, há uma área situada na parte mais próxima da confluência dos rios Anil e Bacanga. Esse ponto ficou conhecido como o local em que os franceses montaram o Forte São Luís em 16.12.1613 ${ }^{90}$. Nessas mesmas imediações, onde foi erguido o forte passou a funcionar as sedes dos poderes que comandaram o Maranhão desde o século XVI. O Palácio do Governo fotografado por Gaudêncio Cunha foi erguido nessa área.

Mas o que acontece dentro do Palácio do Governo e de outros imóveis imponentes de São Luís? O que existe por trás das fachadas das edificações? São nas dependências dos palácios, nos lugares fechados onde acorrem as celebrações apartadas dos transeuntes. Os ambientes fechados precisam existir para, dessa forma, o poder se manter.

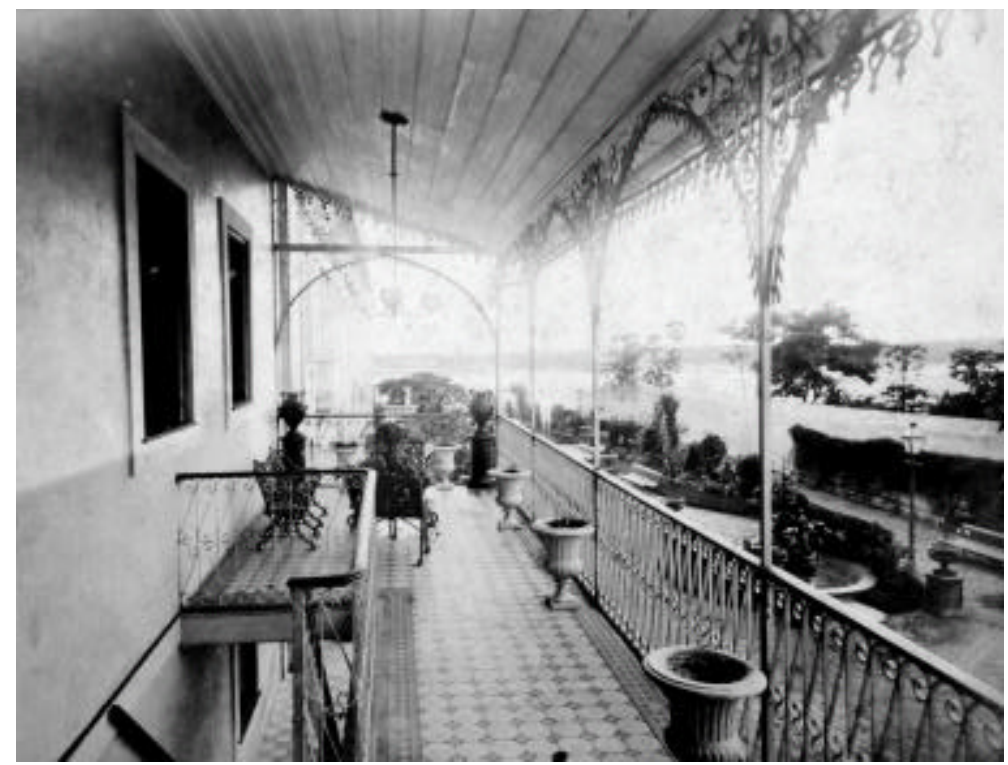

Fotografia 40 Palácio do Governo. Entrada particular. Album..., s.n.p., gelatina/prata, 15 x $20 \mathrm{~cm}$. MHAN.

\footnotetext{
90 Ainda não há estudos históricos e arqueológicos sobre a construção do Forte de São Luiz. O imóvel foi erguido pelos franceses, no início do século XVII, na Ilha de São Luís, próximo à confluência e desembocadura dos rios Anil e Bacanga. Por essa e outras causas, há controvérsias envolvendo a fundação de São Luís. A historiadora Lourdes Lacroix (2002) considera a fundação da cidade pelos franceses uma invenção de intelectuais do final do século XIX e início do século XX. Segundo a autora, em períodos anteriores a esse, os maranhenses creditavam a fundação da cidade aos portugueses, comandados por Jerônimo de Albuquerque que expulsaram os invasores franceses. Os historiadores simpatizantes dessa teoria comparam os franceses a invasores temporários, como os que estiveram no Rio de janeiro no século XVII. A tese de Lacroix não é unânime entre os historiadores. Alguns estudiosos consideram as narrativas dos padres franceses Claude d'Abbeville e Yves D'Evreux, que desembarcaram no Maranhão em 1612 junto com a esquadra francesa e celebraram a primeira missa dentro do forte São Luís, como o mais evidente indício de que a cidade foi fundada pelos franceses. Consultar: LACROIX, Maria de Lourdes L. A fundação francesa de São Luís e seus Mitos. São Luís: Lithograf,2002; D'VREUX, Yves. Viagem ao Norte do Brasil. São Paulo: Siciliano 2002 e (D’ABBEVILLE, Claude. História da missão dos padres capuchinhos na Ilha do Maranhão e suas circuvizinhanças. São Paulo: Siciliano, 2002).
} 


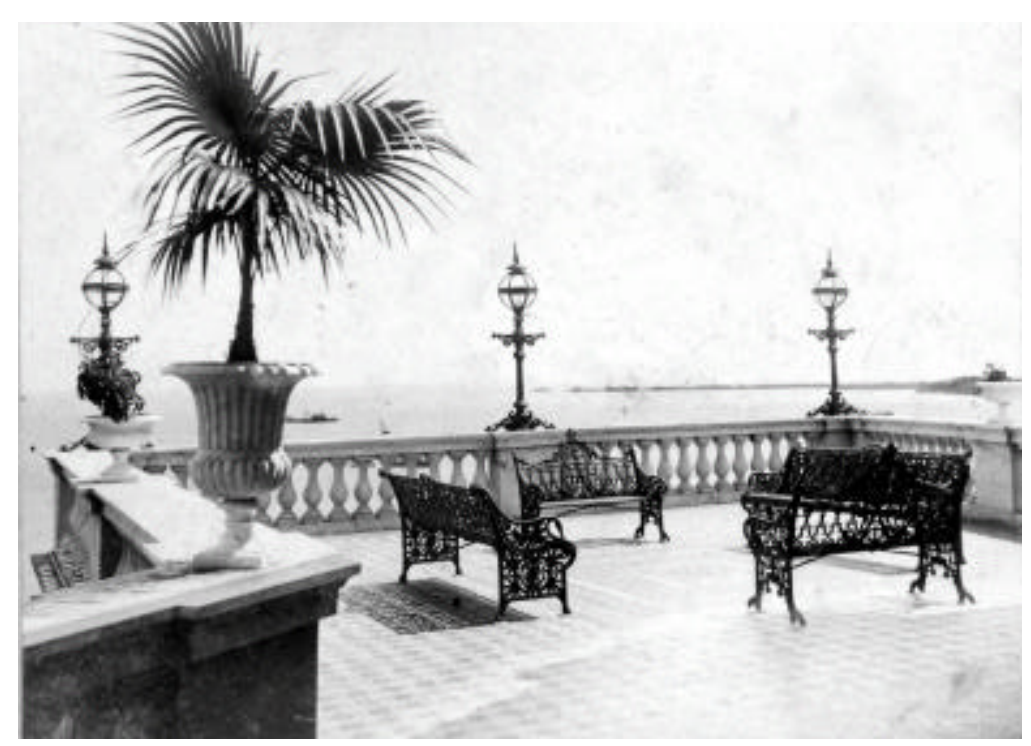

Fotografia 41 - Palácio do Governo. Terraço de palestra. Album..., s.n.p., gelatina/prata, 15 x $20 \mathrm{~cm}$. MHAN.

A ausência de pessoas é visível nas fotografias dos ambientes internos das edificações. Nas dependências do Palácio do Governo e da Intendência Municipal, localizados na Avenida Maranhense, onde não aparece ninguém. Essa vacância acentua ainda mais o silêncio dentro dos imponentes imóveis da Avenida Maranhense. São lugares de silêncio ${ }^{91}$, indispensável para a existência do poder.

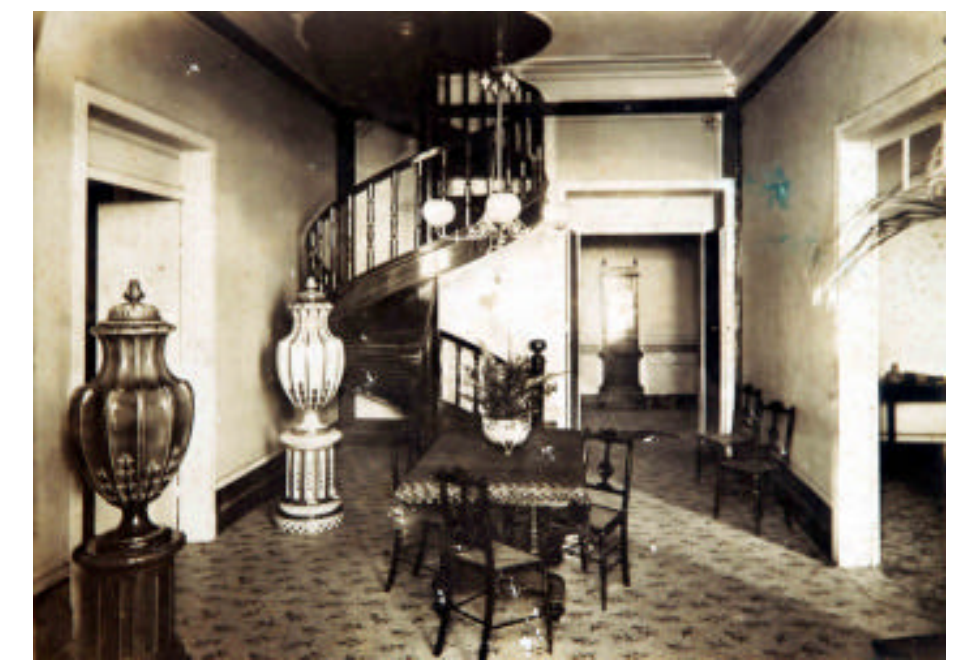

Fotografia 42 - Palácio do Governo. Sala de espera de visitas. Album..., s.n.p., gelatina/prata, 15 x $20 \mathrm{~cm}$. MHAN.

\footnotetext{
${ }^{91}$ BALANDIER, Georges. O poder em cena. Coimbra: Minerva, 1999. p. 30.
} 


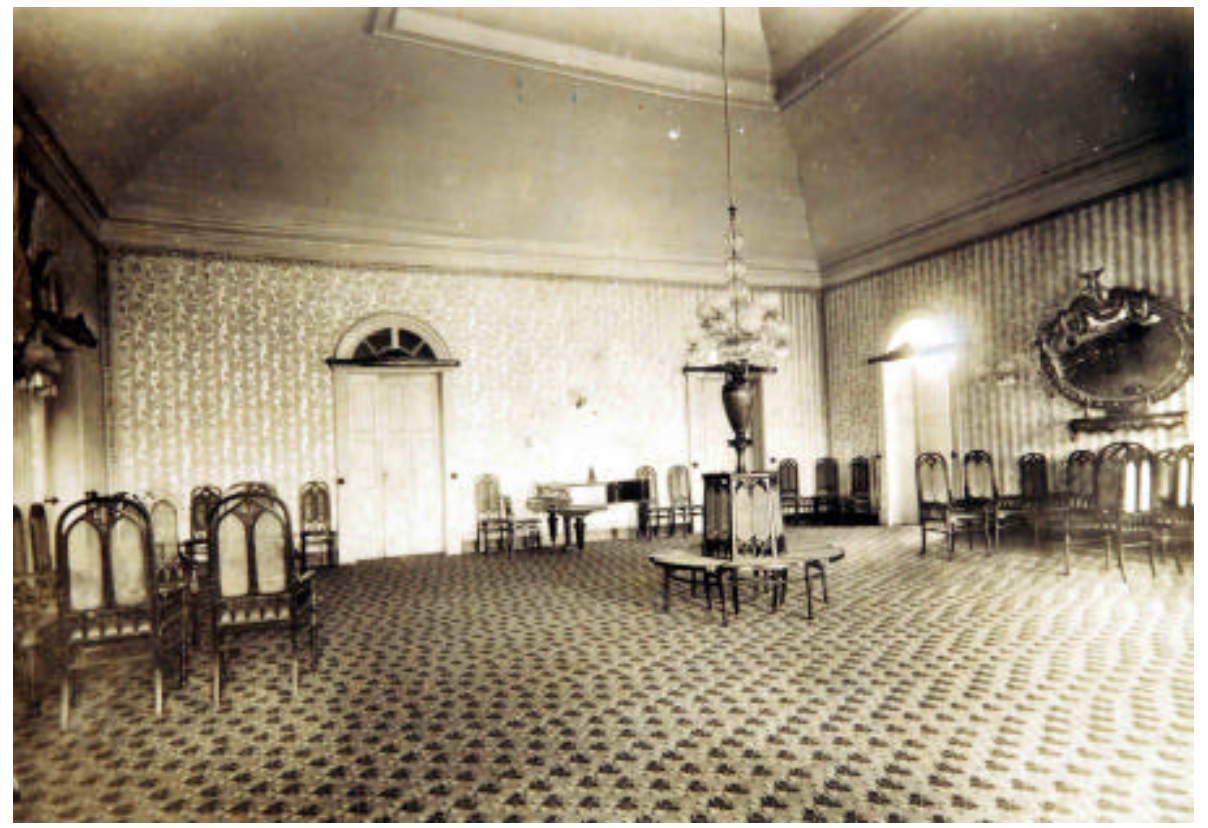

Fotografia 43 - Palácio do Governo. $1^{o}$ Salão. Album..., s.n.p., gelatina/prata, $15 \times 20 \mathrm{~cm}$. MHAN.

No dia 5 de junho de 1906, a cair da tarde, um requintado "banquete de 100 talheres"92 movimentou um espaço interno importante da Avenida maranhense: o Palácio Episcopal. A alta sociedade foi convidada para o jantar oferecido pelo governador Benedicto Leite ao presidente eleito do Brasil, Affonso Penna e sua comitiva. Presentes ao banquete autoridades federais e estaduais, a imprensa e "outros convidados", como estampou a Revista do Norte do mês seguinte. Somente depois desse banquete é que houve as festividades do lado de fora, com a participação dos transeuntes.

O poder precisa sempre celebrar, observa Balandier ${ }^{93}$. Nos seus estudos sobre as encenações do poder, o autor afirma que os acontecimentos fabricados são requeridos como alimento de um espetáculo permanente. Para o poder se repetir ${ }^{94}$ o lugar é uma marca necessária, como o palácio de Versalhes para a monarquia de Luís XVI.

Interessante é que apesar de não ter sido possível recepcionar o presidente do Brasil no Palácio do Governo, que se encontrava em péssimo estado de conservação, o banquete oferecido a Pena não deixou de ser realizado em um imóvel situado na Avenida Maranhense, no caso, Episcopal.

\footnotetext{
${ }^{92}$ Revista do Norte, julho 1906.

${ }^{93}$ BALANDIER, Georges. O poder em cena. Coimbra: Minerva, 1999. p. 99.

${ }^{94}$ Ibid., p. 103
} 


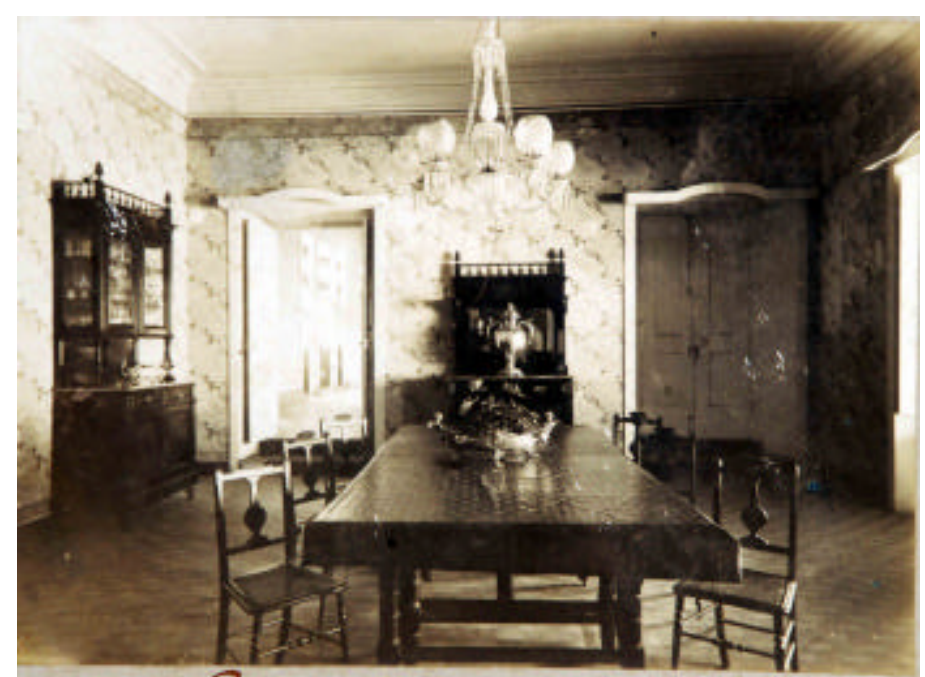

Fotografia 44 - Palácio do Governo. Sala de conversa. Album..., s.n.p., gelatina/prata, 15 x $20 \mathrm{~cm}$. MHAN.

As fotografias internas do Palácio do Governo foram incluídas no álbum, independente do estado de conservação em que se encontrava o prédio na época. Gaudêncio Cunha pode ter construído o conteúdo, excluindo os locais danificados ou apenas ter selecionado imagens que elaborou em outros períodos. O certo é que o álbum de 1908 apresenta os ambientes internos do Palácio do Governo como o local indispensável de legitimação do poder enquanto força estabelecida ${ }^{95}$. São nove fotografias das áreas internas, entre salões e jardins.

O Palácio do Governo era o palco preferencial das festas, reuniões, audiências, banquetes e acordos. Nesse local, políticos, desembargadores, empresários e militares se reuniram no dia 18 de novembro de 1889 para decidir os rumos do Maranhão depois da vigência do sistema republicano no Brasil $^{96}$.

Nos ambientes reservados, o poder silencia frente aos seus comandados em salas e jardins suntuosamente decorados. Para Balandier ${ }^{97}$, o silêncio é parte fundamental dentro da encenação de quem governa: "Os governantes são pessoas de segredo, por vezes justificado pela razão de Estado; e os governados sabem que certas coisas lhe são escondidas" ${ }^{\text {"9 }}$.

Os salões suntuosos do Palácio do Governo guardam silêncios. Estão vazios. O lugar em si é suficiente. A imagem necessária somente do fausto, da mobília e da decoração requintadas ${ }^{99}$. É o lugar de onde o poder comanda.

\footnotetext{
${ }^{95}$ Ibid., p. 22.

${ }^{96}$ VIVEIROS, Jerônimo de. Benedito Leite. Um verdadeiro republicano. Rio de Janeiro: Taveira, 1957. p. 20.

97 BALANDIER, Georges. O poder em cena. Coimbra: Minerva, 1999.

98 Ibid., p.30.

${ }^{99}$ Em Depoimentos concedidos a José Reinaldo Castro Martins em 5.6.2007 e em 3.12.2007, a curadora de Bens Culturais do Palácio dos Leões (Antigo Palácio do Governo), Maria Helena Duboc informa que das mobílias e peças decorativas que integram o conteúdo das fotografias do Palácio do Governo incluídas no álbum de 1908 somente parte do lustre de
} 
Dos jardins e terraços do Palácio do Governo, o poder e seus convidados (aliados) podiam observar quem embarcava e desembarcava pelo porto de São Luís. Do terraço de palestras (Fotografia 41) se olha o porto e mar à distância. A fotografia avisava que dos jardins do Palácio se enxergava longe, em primeira mão, a saída e a chegada de aliados ou inimigos.

Entre as dependências do Palácio do Governo, há uma sala de espera de visitas (Fotografia 42). Ali, os convidados que conseguiram ter acesso ao Palácio esperaram pelo poder. Os visitantes podem ir até o $1^{\circ}$ salão (Fotografia 43) onde o poder tem condições de celebrar o comando com vários convidados ao mesmo tempo. Os acordos, entre poucos, são mais apropriados para a Sala de Conversas (Fotografia 44).

No estudo que fez sobre grupos políticos e estrutura oligárquica no Maranhão, Flavio Reis ${ }^{100}$ situa as ligações entre o público e o privado dentro de um sistema oligárquico. São relações que envolvem pedidos como o de licença sem vencimento para promotores do interior que chegavam a serem encaminhados direto ao governador se o Congresso do Estado não estivesse em funcionamento. $\mathrm{O}$ autor cita também favores e privilégios como isenções fiscais de ordem pessoal e partidária. Por onde entravam esses obséquios? Pela entrada particular (Fotografia 40)? Ou pela sala de espera de visitas (Fotografia 42)?

Os ambientes internos apresentados no álbum de 1908, tanto de imóveis da Avenida Maranhense, como de outros locais da cidade, são carregados de ostentação. É o caso da Câmara, o Cartório, o Congresso do Estado e a própria Photographia União (Fotografia 15). Lá, também há ambientes reservados, como salas de espera e secretarias.

cristal lapidado (Fotografia 44) e os dois potiches que decoram as laterais de uma das portas da Fotografia 42 ainda existem como parte dos bens do Palácio dos Leões. As demais mobílias, em estilos art nouveau e Thonet presentes nas fotografias podem ter vindo da Europa ou terem sido confeccionadas por hábeis carpinteiros maranhenses. O assunto ainda está por ser pesquisado. De acordo com estudos realizados por Duboc, entre o vasto acervo do Palácio dos Leões existem peças decorativas e mobiliários de estilos diversificados: Luís XVII, Império Brasileiro, D. João VI, Luis Felipe, Vitoriano, Biedermier, Beranger, D. José, Napoleão III, entre outros. Ver: DUBOC, Maria Helena. Palácio dos Leões. São Luís: Governo do Maranhão, 2006.

${ }^{100}$ REIS, Flávio. Grupos políticos e estrutura oligárquica no Maranhão. São Luís: Unigraf, 2007, p. 153. 


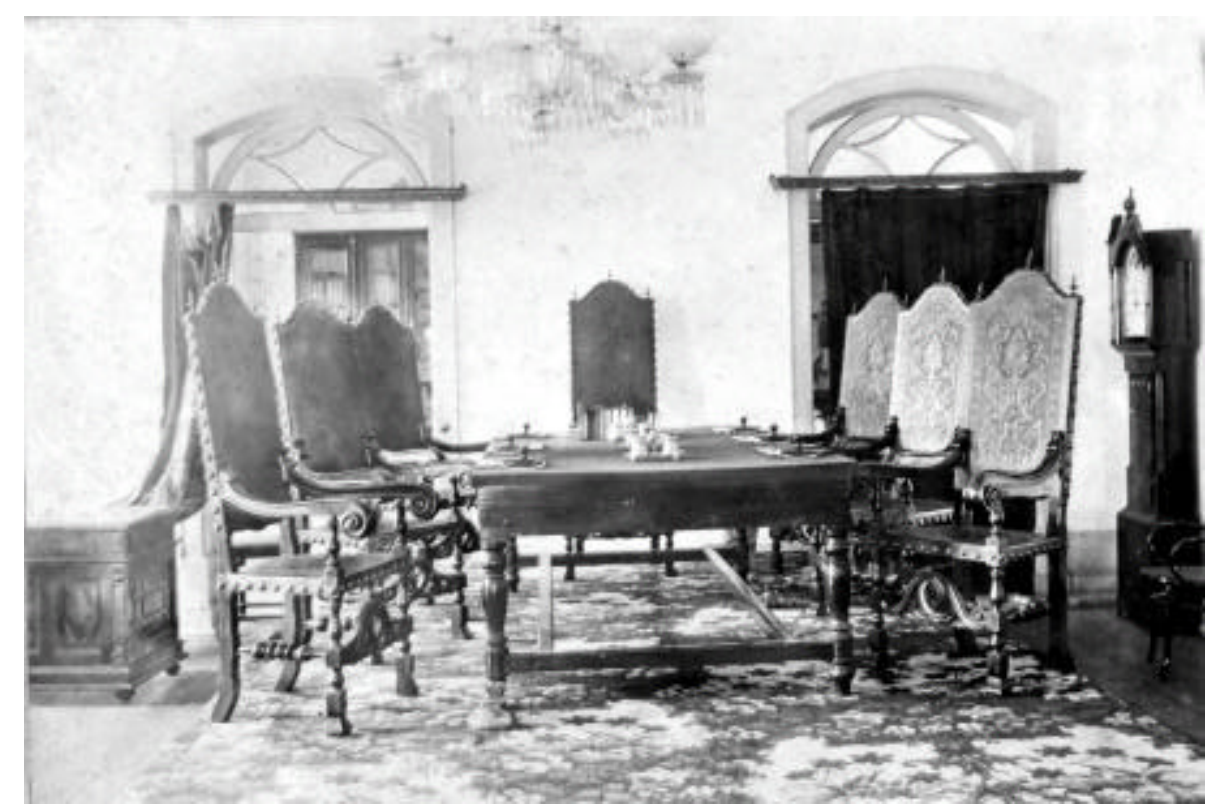

Fotografia 45 - Sala do Superior Tribunal de Justiça do Maranhão. Album..., s.n.p., gelatina/prata, 15 x $20 \mathrm{~cm}$. MHAN.

O Superior Tribunal de Justiça (Fotografia 45) é representado no álbum somente por uma sala que ostenta sete cadeiras vazias, sendo uma a do presidente. Segundo Balandier ${ }^{101}$, os lugares de poder se carregam de atribuições figurativas. Chartier ${ }^{102}$ tocou exatamente nas questões simbólicas, quando diz que "a identidade do ser não seja outra coisa senão a aparência da representação; isto é que a coisa não existe a não ser no signo que a exibe". Isso vale para os médicos que têm a necessidade de vestir becas largas e os magistrados que trabalharem em palácios e usarem trajes suntuosos.

$\mathrm{Na}$ fotografia do álbum, a Justiça se manifesta através de cadeiras com encostos e corrimões requintados. Na mesa, os carimbos simbolizam o poder de decisão do Tribunal. Sete pessoas são suficientes para distribuir, em silêncio, o direito e da Justiça. Entre eles, o superior, na cabeceira da mesa, tem a palavra final no caso de empate. Os rumos dos processos jurídicos são apenas eles que decidem, silenciosamente.

Há fotografias de outros ambientes internos, como os das igrejas. Gaudêncio Cunha fez questão de incluir várias áreas internas do Teatro São Luiz, local reservado não só para apresentações artísticas, mas, também, para grandes recepções.

Dom Xisto, por exemplo, depois da recepção pública apoteótica e antes da despedida melancólica, foi alvo de celebrações de boas vindas no Teatro São Luiz. Às 8 horas do dia 4 de agosto de 1901, o Maestro Antônio Rayol realizou um programa lírico-musical em

\footnotetext{
${ }^{101}$ BALANDIER, Georges. O poder em cena. Coimbra: Minerva, 1999.

${ }^{102}$ CHARTIER, Roger. História cultural: entre práticas e representações. Lisboa: Difel, 1988, p. 19-20.
} 
prol das obras em imóveis da igreja. A arrecadação superior a 4:250\$000 foi destinada a reforma da Catedral da $\mathrm{Sé}^{103}$.

\subsubsection{Fachadas}

As fachadas das edificações cumprem duas funções. Na Avenida Maranhense, por exemplo, servem para separar as relações entre os comandados que transitam na área pública e o poder dominante apartado nos ambientes internos das edificações. Ao mesmo tempo em que separa os dois lados, as fachadas impõem uma intermediação. Permite aos que transitam do lado de fora dos palácios e grandes edificações imaginarem o que acontece do lado de dentro. E essa imaginação é alimentada, proporcionalmente, pela aparência suntuosa das fachadas.

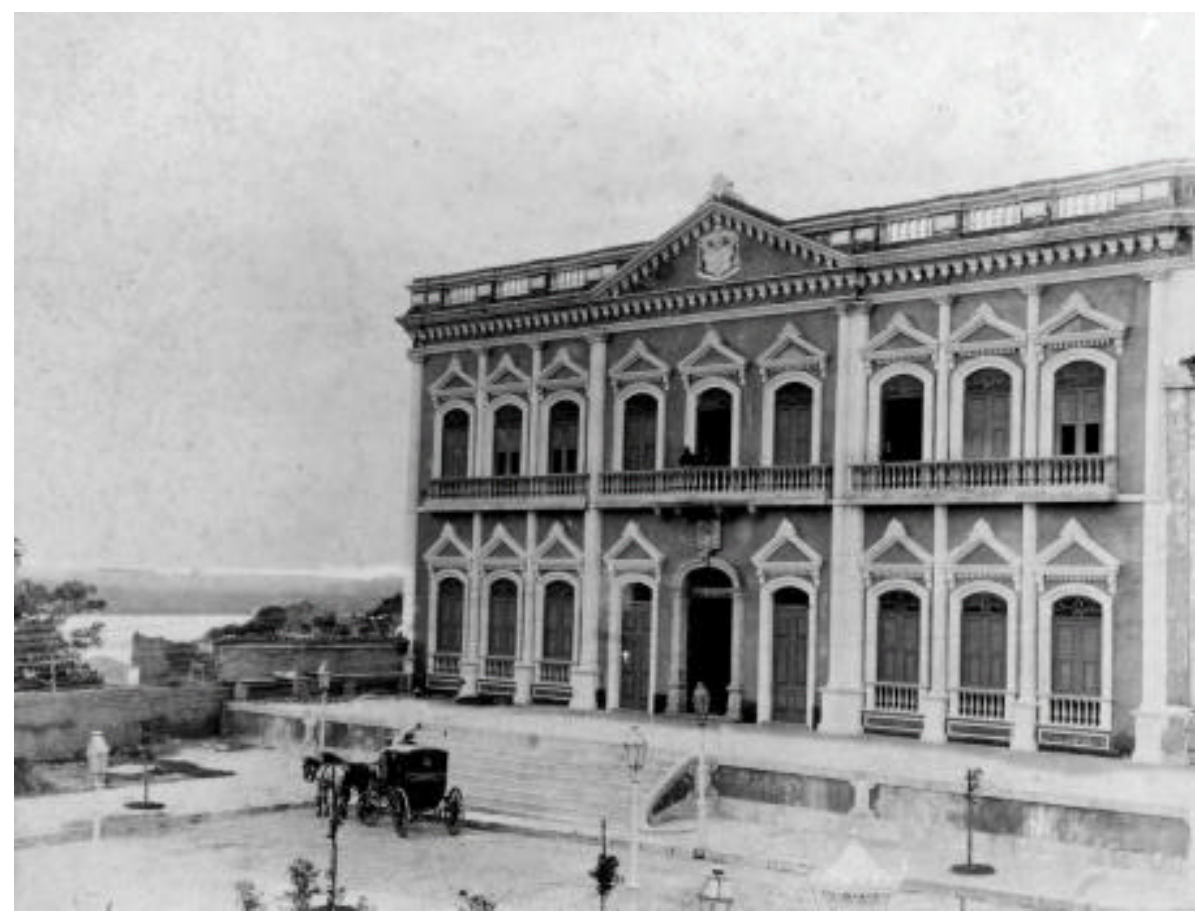

Fotografia 46 - Fachada do Palácio do Bispo. Album..., s.n.p.,gelatina/prata, 16 x $23 \mathrm{~cm}$. MHAM.

Balandier ${ }^{104}$ afirma que os governantes são pessoas de segredo e os governados sabem que certas coisas lhes são escondidas. Por isso, é preciso haver as fachadas para isolar o poder, para apartá-lo dos transeuntes. O que acontece por trás das majestosas fachadas? A pergunta é necessária; a resposta é irrelevante. Ironicamente, o mais importante é incorporar a idéia de que o poder precisa se reservar.

\footnotetext{
${ }^{103}$ PACHECO, Fellipe C. História eclesiástica do Maranhão. São Luís: Departamento de Cultura do Maranhão/Gráfica Lux, 1968, p. 478.

104 BALANDIER, Georges. O poder em cena. Coimbra: Minerva, 1999, p. 30.
} 
São várias as fachadas de imóveis apresentadas por Gaudêncio Cunha, inclusive de algumas choupanas. Mas, aqui, o que interessa são as magníficas fachadas das edificações de poder na época como a do Palácio do Bispo (Fotografia 46) e a Intendência Municipal (Fotografia 48) na Avenida Maranhense. A fachada de frente do Palácio do Governo não aparece porque devia encontrar-se em bom estado de conservação e não havia outra fotografia ideal. Por isso foi influída somente a imagem da fachada lateral (Fotografia 47).

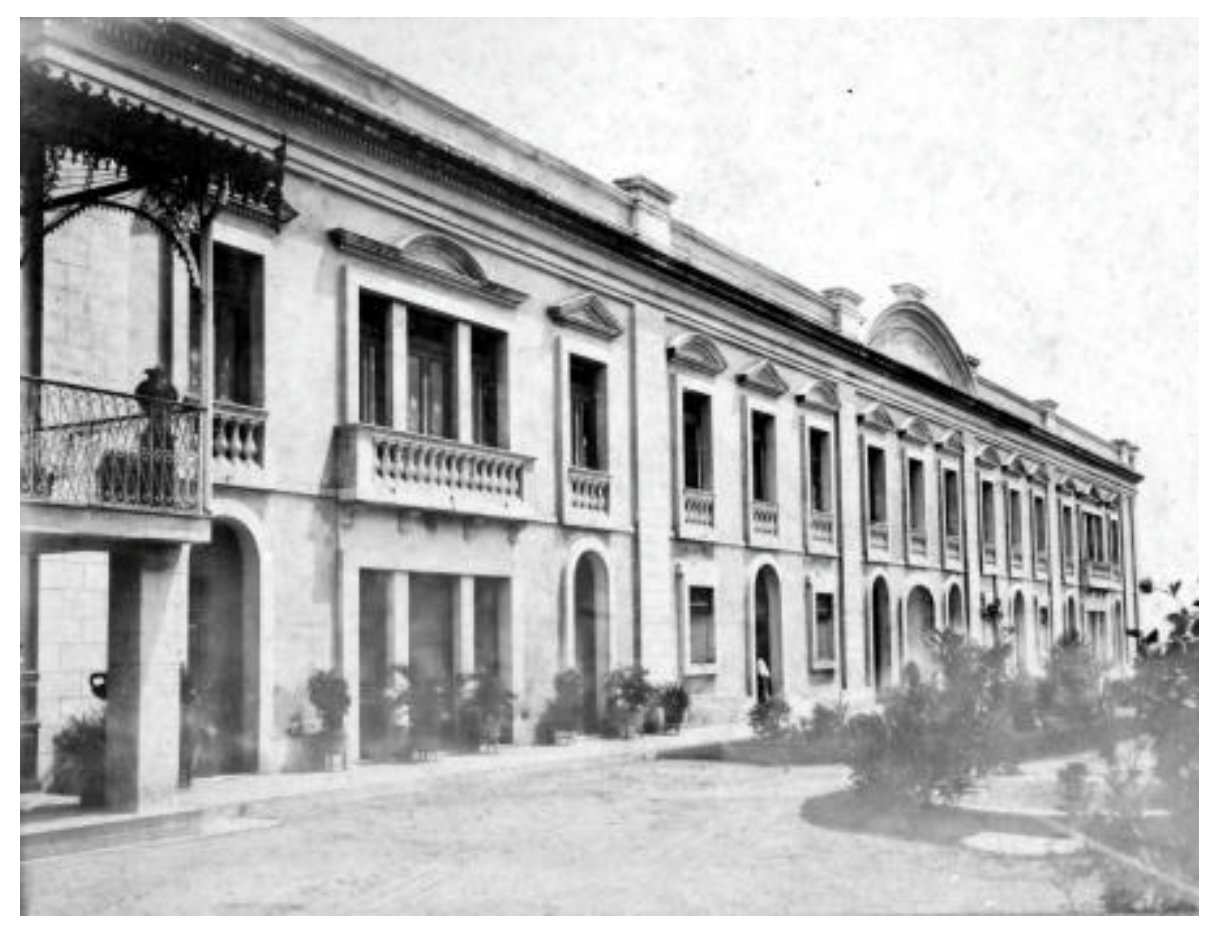

Fotografia 47 - Fachada lateral e interna do Palácio do Governo. Album..., s.n.p., gelatina/prata, $15 \times 20 \mathrm{~cm}$. MHAM.

Enfim, vale retomar a explicação de Balandier ${ }^{105}$ de que o poder necessita de silêncio para se manter e se sustentar. E quando mais suntuosa a fachada, mais acentuada era necessidade daquele poder silenciar para existir. O poder para se manter precisa se repetir diariamente $^{106}$. E as fachadas cumpriam exatamente o papel, o de ecoar para os transeuntes, todos os dias, que o poder tem pompa, existe e é reservado. O mistério, o escondido nos ambientes internos manifesta sua existência através das fachadas para os comandados que transitam do lado de fora.

\footnotetext{
${ }^{105}$ Ibid.

${ }^{106}$ Ibid., p. 130
} 


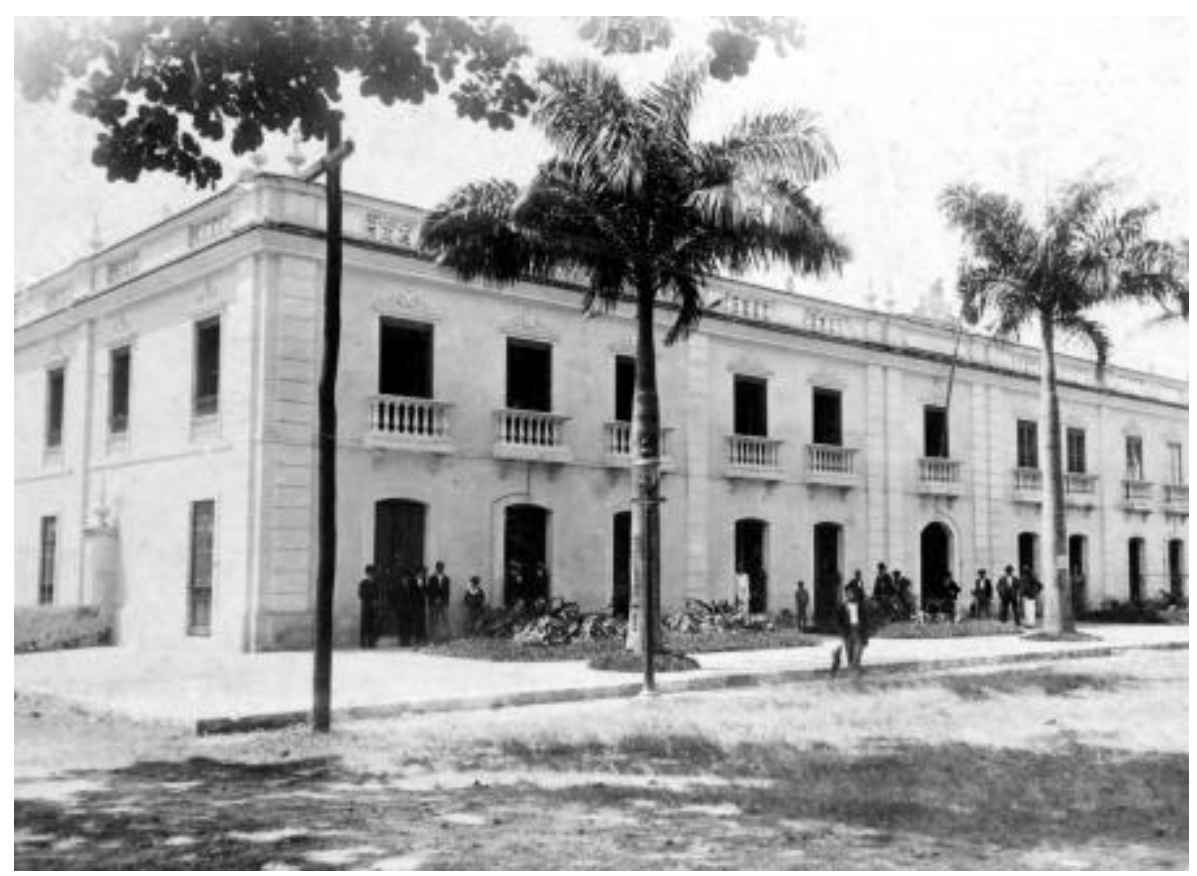

Fotografia 48 - Fachada da Intendência Municipal. Album..., s.n.p., gelatina/prata, 16 x $22 \mathrm{~cm}$. MHAM.

\subsubsection{Praça Benedito Leite}

Muito próximo da Avenida Maranhense encontra-se a Praça Senador Benedicto Leite $^{107}$ (Fotografia 49), anteriormente denominada Jardim 13 de Maio, Praça João Velho ou do Val e Praça da Assembléia. Está localizada perto do ponto de passagem (Fotografia 39) que dá acesso à Avenida Maranhense. Dessa praça, segue-se a Praça João Lisboa/Largo do Carmo e as ruas que dão acesso à outra área abertura da cidade, a Praça Marechal Deodoro, o antigo Largo do Quartel (Fotografia 52).

O Hotel Central (Fotografia 50), um símbolo de modernidade de São Luís, é estrategicamente centralizado entre a Avenida Maranhense e a Praça Benedito Leite. Nesse prédio, os visitantes são observados e observam os poderes institucionalizados, através da Avenida Maranhense; ao mesmo tempo em que tem acesso à cidade pela praça ajardinada da Praça Benedicto Leite. Nos salões do Hotel Central, médicos maranhenses da época ofereceram um jantar de boas vindas, no dia 4 de novembro de 1905, para o médico Oswaldo Cruz $^{108}$.

\footnotetext{
${ }^{107}$ A praça é chamada Senador Benedito Leite na edição da Revista do Norte de $1^{\circ}$ de julho de 1903.

${ }^{108} \mathrm{O}$ assunto é comentado por Justo Jansen na Revista do Norte de novembro 1905.
} 


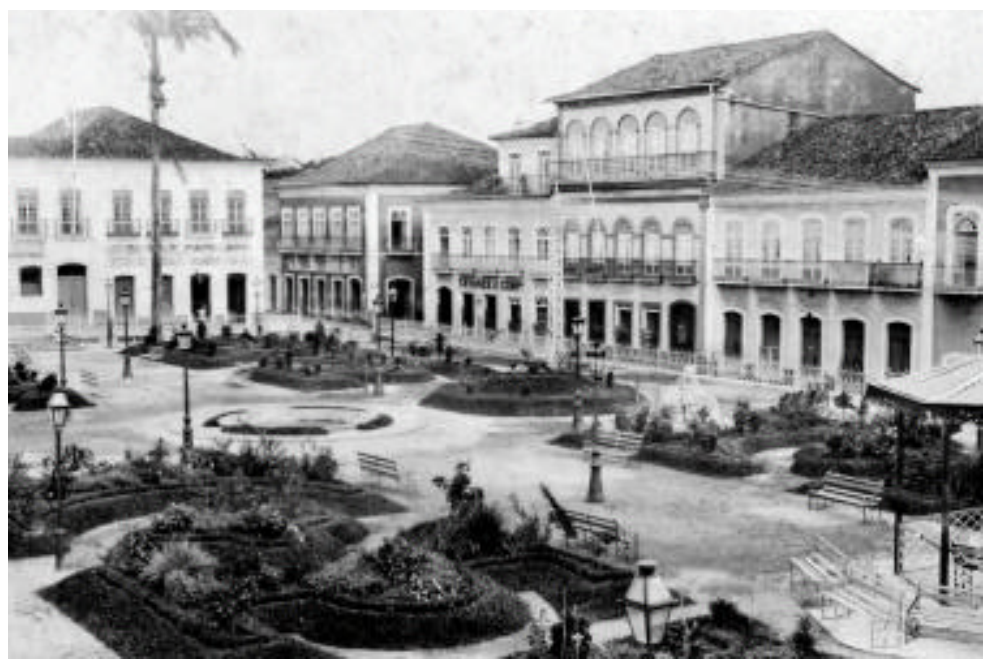

Fotografia 49 - Praça Benedicto Leite. Album..., s.n.p., gelatina/prata, 15 x $20 \mathrm{~cm}$. MHAM.

Os canteiros da Praça Benedicto Leite são racionalmente cuidados. O local foi ajardinado em 1906, no próprio Governo Benedicto Leite ${ }^{109}$. Por isso mesmo não poderia deixar de sair no álbum. Era o cenário agradável para os viajantes [...] as praças de São Luís são arborizadas com muito gosto [...] elogiou o viajante Annibal Amorim ${ }^{110}$. Cercando a jardinagem estão os velhos casarões com beirais dos tempos do Império/Colônia.

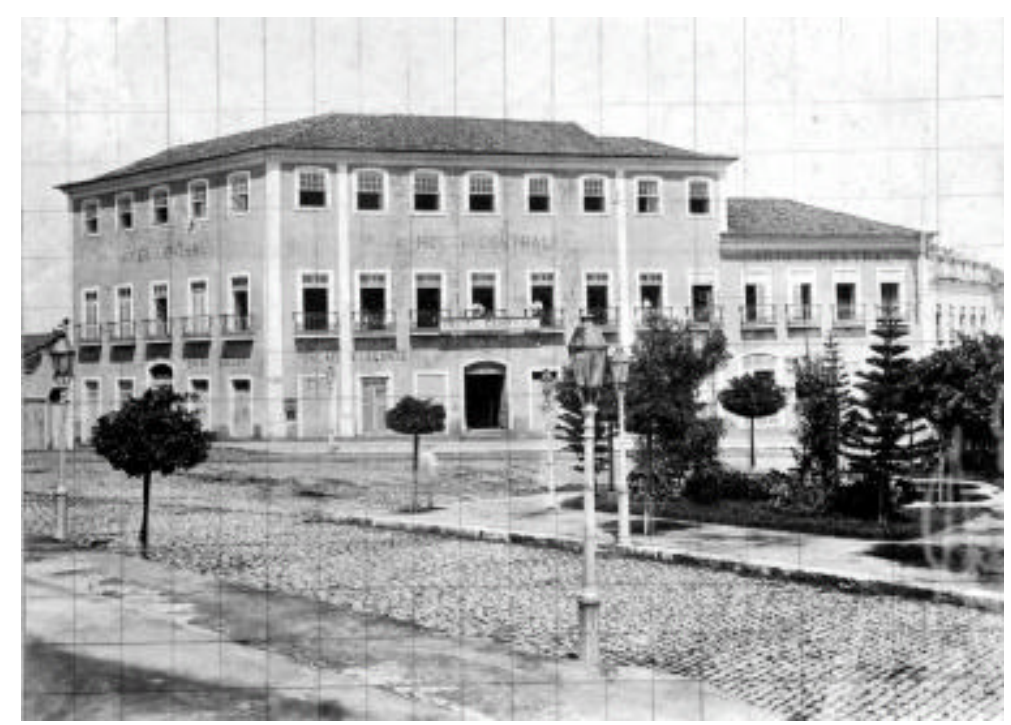

Fotografia 50 - Hotel Central. Album..., s.n.p., gelatina/prata, 15 x $20 \mathrm{~cm}$. MHAM.

${ }^{109}$ MONUMENTOS HISTÓRICOS DO MARANHÃO. São Luís: Ministério do Interior/Projeto Rondon/SIOGE, 1979.

${ }^{110}$ AMORIM, Aníbal. Viagem pelo Brasil. Do Rio ao Acre - Aspectos da Amazônia - Do Rio a Matto Grosso. Rio de Janeiro: Livraria Garnier, 1917. p. 113. 


\subsubsection{Companhia de Bombeiros}

Entre fotografias de antigas igrejas, belos palácios e residências, eis que surge no álbum de 1908 um emblema da modernidade da época: a Companhia de Bombeiros. O serviço da Companhia de Bombeiros é exibido em detalhes através de 5 fotografias. Uma das imagens apresentadas é a da fachada do Quartel com os carros de bombeiros à frente (Fotografia 52). As demais incluem os bombeiros e dos veículos da corporação (ver Ilustração 14). O trabalho dos bombeiros já fazia parte do dia-a-dia da cidade, apesar do serviço ter sido recém implantado ${ }^{111}$. Apresentava-se como motivo de orgulho para seus moradores. Informações sobre o funcionamento da Companhia eram regulares em algumas publicações. Há fotografias dos bombeiros no quartel, na Revista do Norte de novembro de 1905.

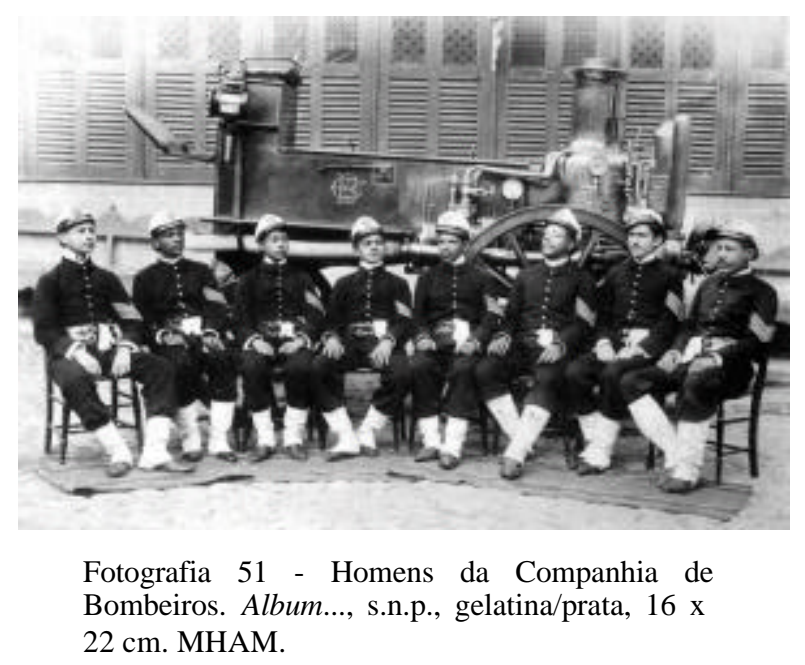

\footnotetext{
${ }^{111}$ O governador João Costa foi o idealizador da Companhia de Bombeiros. A sua manutenção ficou sobre a responsabilidade da Intendência Municipal de São Luiz e o Governo do Maranhão. Companhias de seguro com atividades no Maranhão financiariam o trabalho comprando o Material necessário na Capital Federal. (MARANHÃO. Mensagem que o Exmº Sr. João Gualberto Torreão Costa apresentou ao Congresso Legislativo do Maranhão, em 13 de fevereiro de 1901. Imprensa Official do Maranhão, 1901). A Lei n.204 de 10 de abril de 1901 autorizou a criação da secção de Bombeiros em São Luís. O Decreto n.32 de 10 de dezembro de 1903 modelou os serviços de bombeiros do Maranhão ao da capital Federal. O município deveria entrar com a quota de Rs. 25:000\$000 por ano e o Estado com Rs 30:000\$000, o que incluía a manutenção de uma oficina de treinamento para os bombeiros. (MARANHÃO. Mensagem que o Exmo ${ }^{\circ}$ Sr. Governador Benedicto Pereira Leite apresentou ao Congresso Legislativo do Maranhão, em 7 de fevereiro de 1907. Imprensa Official do Maranhão, 1907).
} 


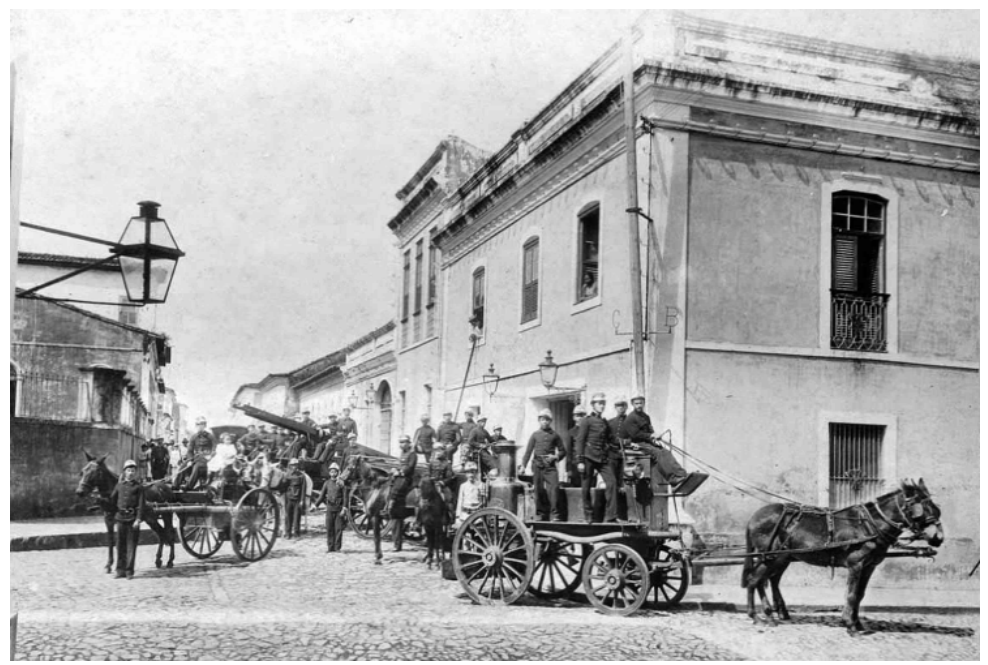

Fotografia 52 - Prédio do Quartel da Companhia de Bombeiros, com os bombeiros e veículos. Album..., s.n.p., gelatina/prata, 24,8 x $33,7 \mathrm{~cm}$. MHAM

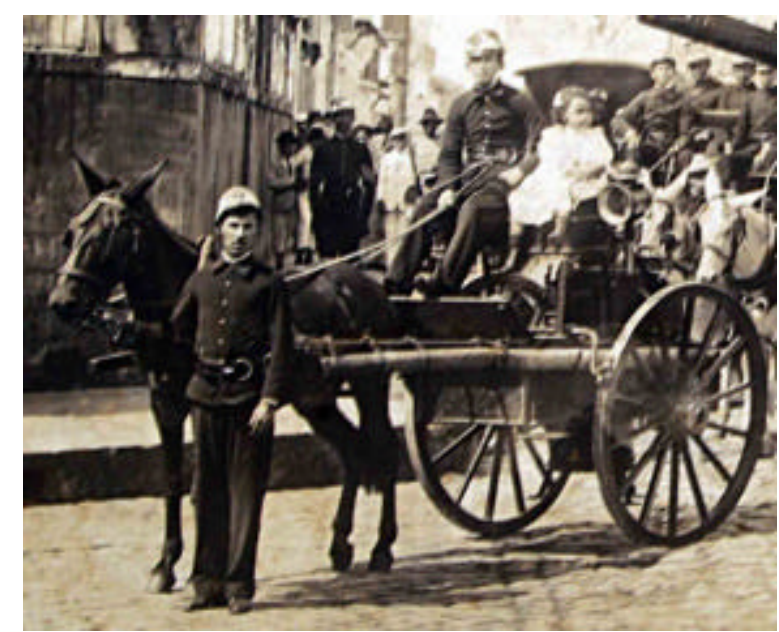

Ilustração 15 - Menina sentada em um dos veículos da Companhia de Bombeiros. Detalhe da Fotografia 52

Um dos ícones da Companhia de Bombeiros era a banda musical que animou várias celebrações da cidade, como a recepção de chegada do presidente Affonso Penna, na tarde do dia 5 de julho, na Avenida maranhense ${ }^{112}$.

O grupo de bombeiros (Fotografia 51) apresenta a imagem ideal de uma República que desejava apresentar-se livre do sistema de escravidão. Na fotografia, brancos e negros se unem para formar o contingente. Todos fardados, limpos e patenteados, representam a imagem desejada de um Brasil distante da imagem escravagista.

Diante do quartel (Fotografia 52), os bombeiros posam para a fotografia. O fotógrafo teve dificuldades para apresentar todos os veículos. Foi impossível colocá-los todos de frente, um ao lado do outro, porque a rua não era suficientemente larga. Os carros estão

\footnotetext{
${ }^{112}$ Revista do Norte, julho de 1906.
} 
amontoados, pois o espaço apertado da rua inviabiliza a colocação deles lado a lado. Gaudêncio Cunha fez o possível para o local sair largo, apesar do lustre incluído no conteúdo dar uma idéia da largura.

Estariam os veículos, em frente ao quartel posando em prontidão? Evidente que não. Tratar-se de uma encenação para a câmara fotográfica. O trabalho do fotógrafo chamou a atenção e mobilizou a corporação. Pelo menos um jornal citou uma presença de Gaudêncio Cunha no pátio do quartel dos bombeiros “[...] Cremos que a photographia tem de figurar no álbum que o Estado mandará breve para a Exposição Nacional [...], sugere A Pátria"113.

O frisson em torno do trabalho de Gaudêncio Cunha movimentou o quartel. Tudo ficou muito bem arrumado para a câmara do fotógrafo. Alguém aproveitou a oportunidade para incluir uma menina muita bem vestida em cima de um dos veículos (Ilustração 15). A garota e uma senhora que aparece em uma das janelas do quartel são as únicas do sexo feminino incluídas na fotografia. A senhora da janela é plausível de aparecer, pois os curiosos existem em qualquer lugar. Mas, a garota é um diferencial na composição da imagem, pois ela é parte da encenação, apesar de não compor a caserna.

\subsubsection{Igreja dos Remédios}

As igrejas fotografadas para o álbum de 1908, em sua grande maioria, remontam aos tempos do Império e da Colônia. A de Nossa Senhora dos Remédios (Fotografia 53) era uma exceção. Apesar de a primeira ermida ter sido erguida em $1719^{114}$, o templo foi praticamente todo construído no início do século XX.

As estátuas dos evangelistas, que estão na parte superior da frente da igreja haviam sido colocadas há pouco tempo, pois em fotografia publicada na Revista do Norte em 1903, as esculturas ainda não havia sido incluídas ${ }^{115}$.

Fugindo à regra, a igreja dos Remédios é um símbolo da modernidade casada com a velha religiosidade. A fotografia desse templo mostra a fachada e a lateral. Em volta da Igreja dos Remédios circularam - pelo menos desde meados do século XIX - pessoas de destaque da sociedade Maranhense. Na década de 1850, quando João Lisboa lançou farpas

\footnotetext{
113 A Pátria, 6.5.1908.

${ }^{114}$ Monumentos históricos do Maranhão. São Luís/Ministério do Interior/Projeto Rondon/SIOGE, 1979, p. 122.

${ }^{115}$ Revista do Norte 01.12.1903.
} 
contra Gonçalves Dias, a festa de Nossa Senhora dos Remédios já agitava a vida cultural de São Luís ${ }^{116}$.

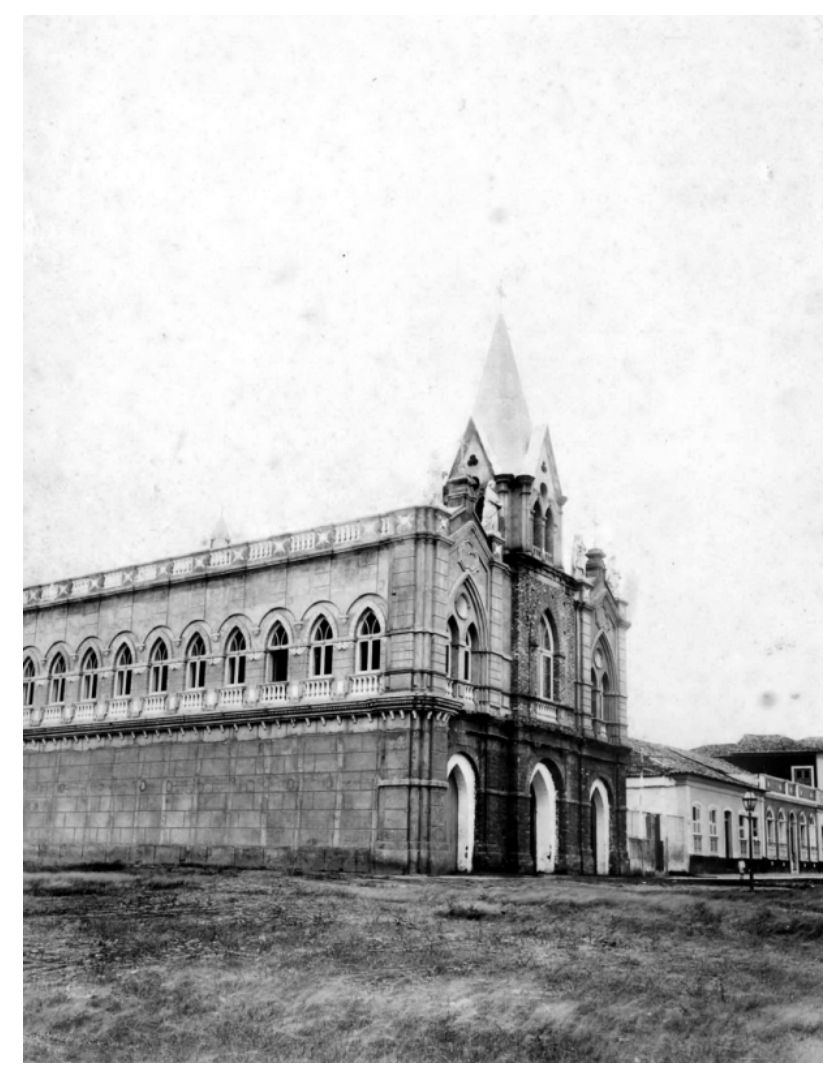

Fotografia 53 - Igreja dos Remédios. Album...,s.n.p., gelatina/prata, 35,4 x $28 \mathrm{~cm}$. MHAM.

Em setembro de 1900, Gaudêncio Cunha integrou a Comissão de Artistas incumbida de angariar donativos para a $3^{\circ}$ Novena da Festa de Nossa Senhora dos Remédios. É importante explicar que o termo artista, na época, era empregado para designer os mestres em ofícios liberais entre os quais os pintores de quadros e fotógrafos ${ }^{117}$. Entre os retratistas da comissão encontrava-se Gregório Pantoja, que veio de Belém com Gaudêncio Cunha e Marcelino de Jesus Nina, que foi sócio de Pantoja, além do consagrado pintor da época, Luiz $\mathrm{Luz}^{118}$.

Participaram da organização e de comissões da Festa dos Remédios em 1900 outras celebridades da época, como o músico Antonio Rayol e os escritores e historiadores Antônio B. Barbosa de Godóis, Justo Jansen Ferreira e Antonio Lobo, o fundador da

\footnotetext{
${ }^{116}$ LISBOA, João F. A Festa de Nossa Senhora dos Remédios. São Luís: Editora Legenda, 1992, p. 51.

${ }^{117}$ A Comissão dos Artistas na $3^{a}$ Novena de Nossa Senhora dos Remédios dividiu-se entre alfaiates, sapateiros, marceneiros, carapinas, funileiros, serralheiros, canteiros, maleiros, ourives, pintores, calafates, carapinteiros, mechanicos, charuteiros, retratistas, tanoeiros, carapinas, caldeiros, pedreiros, barbeiros, velleiros, fogueteiros, armadores, Typographos, encadernadores e chapeleiros.

${ }^{118}$ Diário do Maranhão, 18.09.1900.
} 
Academia Maranhense de Letras. As novenas reuniam normalistas, professores, diretores de colégios, funcionários públicos, entre outros ${ }^{119}$.

\subsubsection{O lugar do 'saber'}

Segundo o historiador Barros Martins ${ }^{120}$, ao final do século XIX e início do século XX, havia no Maranhão um grupo de intelectuais que se identificava com a idéia de dar continuidade a um passado de glórias maranhenses que teria acontecido no início até meados do século XIX. Esses homens passaram para a história com os Novos Atenienses. Eram assim denominados porque se viam como sucessores de intelectuais do passado, Gonçalves Dias, João Lisboa e outros que pelo 'saber' teriam feito o Maranhão (ou São Luís, especificamente) ser denominado de Athenas Brasileira. Um dos objetivos deles era manter os intelectuais maranhenses no Maranhão.

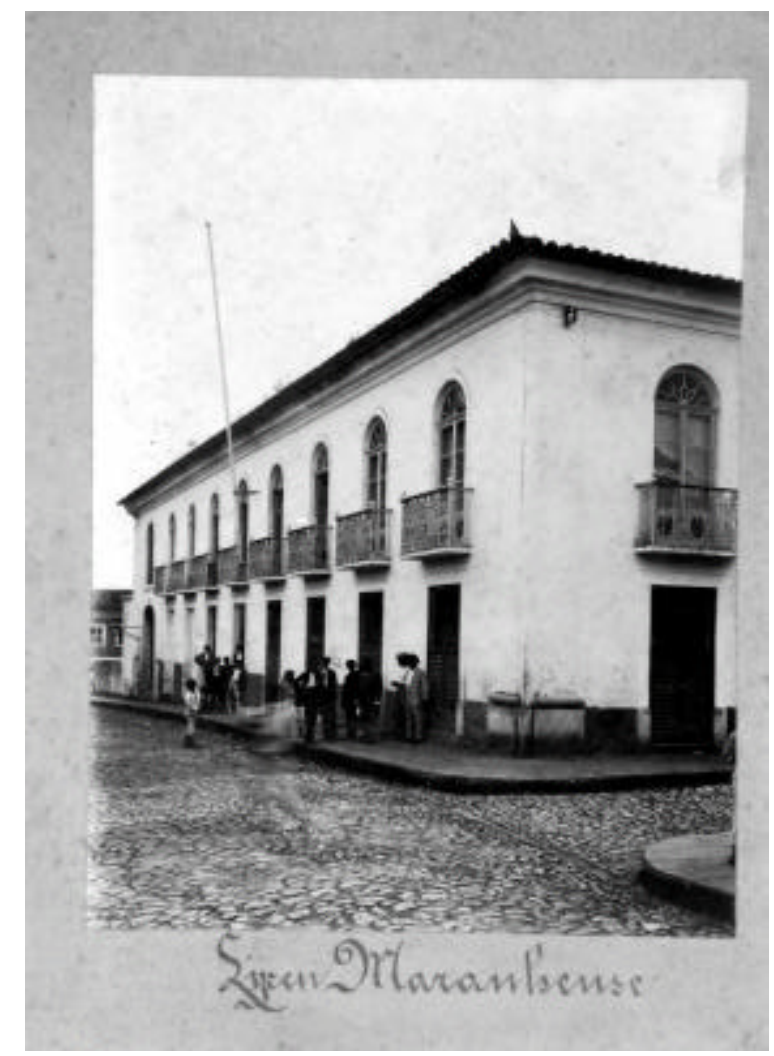

Fotografia 54 - Prédio do Liceu Maranhense. Album..., s.n.p., gelatina/prata, $18,5 \times 13,8 \mathrm{~cm}$. MHAM.

\footnotetext{
${ }^{119}$ Diário do Maranhão, 06.09.1900.

${ }^{120}$ MARTINS, Manuel B. Operários da Saudade: os novos atenienses e a invenção do Maranhão. São Luís: Edufma, 2006.
} 


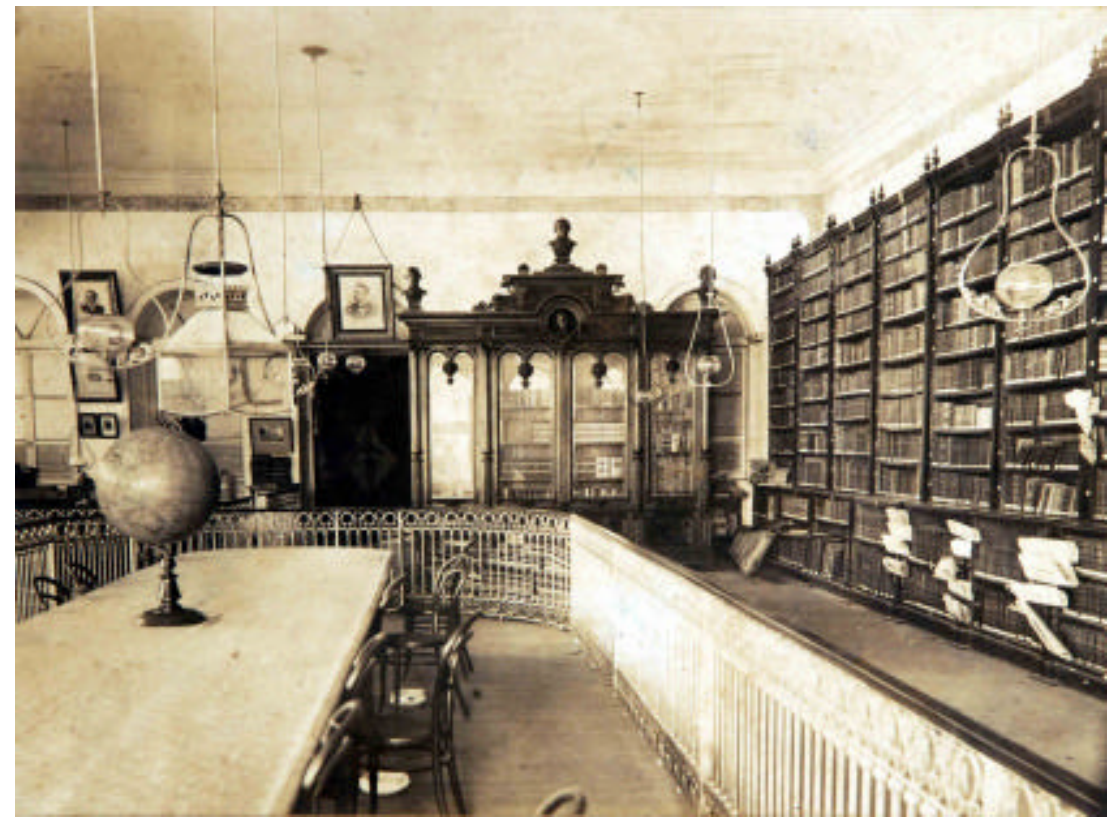

Fotografia 55 - Sala de Leitura da Biblioteca Pública. Album..., s.n.p., 14 x $21 \mathrm{~cm}$. MHAM.

Os Novos Atenienses certamente circulavam com desenvoltura nos ambientes internos das instituições educacionais, algumas delas destacadas no álbum (Fotografias 55 e 56). Foram alunos dessas instituições ou estavam à frente de suas congregações. Organizavam conferências literárias e científicas nesses locais, como observa Barros Martins ${ }^{121}$. Apesar de manterem ligações com essas instituições, vários deles completaram a sua educação estudando fora de São Luís, em faculdades com a de Direito de Olinda ${ }^{122}$.

O 'saber', ao que deixa transparecer nas fotografias, também precisava se apartar e silenciar para poder existir. As salas e os salões das congregações do Liceu e da Escola Normal indicam que há um poder decisório separado, inclusive das salas de aula.

No campo do ensino, a modernidade já adentrava as salas de aula, representada no álbum pela Sala de aula de chimica (Fotografia 56) e a de desenho. No ambiente escolar, também havia glamour. Os móveis são requintados e as salas repletas de equipamentos científicos e as paredes são decoradas com gravuras.

\footnotetext{
${ }^{121}$ Ibid, p. 184.

${ }^{122}$ CORREAA, Rossini. Formação social do Maranhão: o presente de uma arqueologia. São Luís: SIOGE, 1993 p. 153.
} 


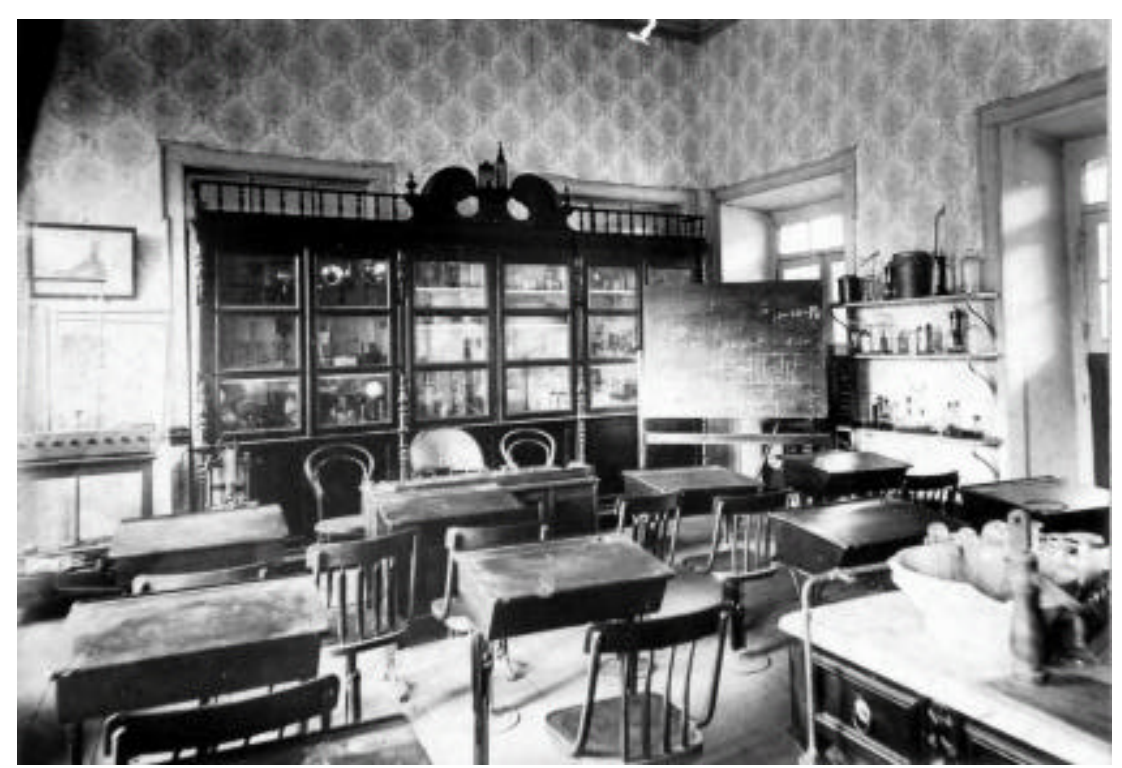

Fotografia 56 - Sala de aula de Chimica (Química) da Escola Normal. Album..., s.n.p., 14 x 21cm. MHAM.

O alinho e as cerimônias levam a crer que os ambientes internos das instituições educacionais eram para poucos privilegiados. A fachada da Biblioteca Pública, já com ares modernos, separava os transeuntes comuns do ambiente interno desse 'núcleo de saber'. Na sala de leitura (Fotografia 55), o globo indica a presença da modernidade no local. Os móveis são quase tão requintados como os dos palácios da Avenida Maranhense. Os retratos de autoridades ou de intelectuais emoldurados, ao fundo e no alto das paredes, indicam a existência de um poder estabelecido e superior. Do 'lado de dentro' as regras institucionalizadas estabelecem as hierarquias. A grade separando as estantes de livros da mesa de leitura da biblioteca (Fotografia 55) indica que havia limites de movimento entre os freqüentadores do local.

Qual a necessidade de se incluir fachadas e ambientes internos de centros de saber como escolas e bibliotecas no álbum de 1908? Essas imagens transparecem a necessidade de se apresentar no álbum uma das mais cultuadas singularidades maranhenses, a que apresenta São Luís como a Athenas brasileira, a terra de poetas e escritores.

Nas ruas, avenidas e praças de São Luís havia também celebrações populares enaltecendo o saber. O Cortejo em Glorificação ao poeta Gonçalves Dias, com ampla cobertura fotográfica na Revista do Norte ${ }^{123}$, é um exemplo. Ao que tudo indica, celebrações

\footnotetext{
${ }^{123}$ Revista do Norte, 16.11.1904.
} 
públicas em honra ao 'saber' aconteceram também, nessa mesma época, em outras cidades brasileiras. Em Belém foi organizado o préstito fúnebre a Carlos Gomes em maio de $1896^{124}$.

Por que cultuar um passado de glórias no Maranhão? Seria para atenuar os reveses da crise econômica? Barros Martins ${ }^{125}$ faz ligações entre o ímpeto quixotesco dos Novos Atenienses e a crise econômica.

$\mathrm{O}$ culto ao passado, de uma forma geral e diferenciada, contagiou intelectuais maranhenses desde as últimas décadas do século XIX. O poeta Joaquim de Sousa Andrade, o Sousândrade (1833-1902) ${ }^{126}$, por exemplo, mesmo sendo árduo defensor do Regime Republicano ${ }^{127}$ reverenciou com ênfase a Monarquia. ${ }^{128}$.

Ao mesmo tempo em que conferiu boas-vindas à República, ele adicionou deferências educadas ao passado monárquico, através de seus poemas ${ }^{129}$ e escritos. Em carta encaminhada a Deodoro da Fonseca em 17 de novembro de 1889, Sousândrade clama por conciliação: “[...] Passaram as trevas; estamos na luz. Não amaldiçoemos o passado... Que, pois ninguém maldiga o ex-imperador! A ex-imperial família, sendo agora família nossa irmã, deve estar também sentindo a nossa alegria, a alegria nacional [...]"130.

Apesar das reverências às novidades modernas, o culto ao passado soou como necessário no Brasil republicano. No álbum de 1908, esse aspecto é visível em fotografias como a da velha Rua 28 de Julho, ou Rua do Giz (Fotografia 58). Por outro lado, era imperativo, também, se fazer cortesias à modernidade. Tanto Sousândrade quanto Gaudêncio Cunha reverenciaram as novas idéias e tecnologias de sua época. Mas, então, o que fazia essa

124 NUNES, Benedito; HATOUM, Milton. Crônicas de duas cidades: Belém e Manaus. Belém: SECULT, 2006, p. 36.

${ }^{125}$ MARTINS, Manuel B. Operários da Saudade: os novos atenienses e a invenção do Maranhão. São Luís: Edufma, 2006, p. 115-116.

${ }^{126}$ Sousândrade viveu nesse período, mas é um pouco anterior aos Novos Atenienses.

${ }^{127}$ A defesa da república é uma marca na obra de Sousândrade, reconhecida por críticos e historiadores. Ver Rossini Corrêa (1993, p. 157-158)

128 Sousândrade viveu a sua infância e a adolescência em São Luís. Em 1853 realizou uma viagem pela Amazônia. Estudou em Paris e Londres entre 1853 e 1857. Retornou para São Luís, onde permaneceu entre 1857 e 1870. Residiu em New York entre 1871/1885. Em 1885, viajou pela América Central, Peru, Chile e Argentina. Passou seus últimos anos - entre 1885 e 1902 - em São Luís. (WILLIAM Frederick G; MORAES, Jomar. Poesias e Prosas Reunidas de Sousândrade. São Luís: AML/UFMA? Fundação Sousândrade, 2003). Gaudêncio Cunha viveu no Maranhão na década de 1890 até o ano de sua morte, 1920.

${ }^{129}$ Para Augusto e Haroldo de Campos, Sousândrade foi escritor inovador dentro da literatura brasileira. "No quadro do romantismo brasileiro, mais ou menos à altura da denominada $2^{a}$ geração romântica (conceito cronológico), passou clandestino um terremoto" (1982, p. 19), definem os poetas paulistas. Segundo eles, a obra de Sousândrade é pouco conhecida e incompreendida até mesmo por críticos como José Veríssimo (p.20). Por outro lado, ao que tudo indica, agradava um seleto público de intelectuais que vivia em São Luís da época. Provavelmente os mesmo que se indignaram através de artigo no jornal Pacotilha de $1^{\circ}$ de maio de 1902 - frente à apatia da sociedade de São Luís à morte do poeta. Isso mesmo depois dele ter se destacado na sociedade maranhense, desempenhado, entre outros papéis, o de intendente (prefeito) da cidade (Ibid, p. 527).

${ }^{130}$ Ibid, 2003, p. 511-512. 
modernidade do início do século XX ao lado de ícones dos tempos da Colônia e do Império, como chafarizes (Fotografia 14 e 28) das avenidas e praças de São Luís?

A inclusão da modernidade pode ser justificada de várias maneiras. Imagens como a da Companhia de Bombeiros ajudava a população a se acostumar com as novidades. Os irmãos Augusto e Haroldo Campos ${ }^{131}$, por exemplo, nas considerações que fizeram sobre Sousândrade, lembram que Walter Benjamim buscou a apreensão de pinturas impressionistas que apresentavam a rua com grande movimento de pessoas “[...] que ao espetáculo cotidiano de uma multidão em movimento fosse ademais preciso que os olhos se acostumassem [...]"132.

Com relação às venerações ao antigo, em particular ao que se refere ao Maranhão, a questão é mais complexa. Primeiro porque fenômenos como surgimento dos Novos Atenienses aconteceu em um momento de crise econômica. Também havia situações sociais ainda mal resolvidas no campo das relações cotidianas, principalmente as que envolviam convivências igualitárias entre pessoas de raças diferentes. A vigência de novidades como o trabalho livre para todos, ainda deixava no ar posições sociais pretensamente diferenciadas, pois a escravidão acabara de ser abolida.

\section{3. $O$ interior maranhense}

As igrejas católicas e as fábricas se destacaram no Álbum de 1908 entre as poucas fotografias que invocavam o mínimo de urbanidade em localidades do interior maranhense. Gaudêncio Cunha, nas fotografias do interior, destacou, também, paisagens da natureza, principalmente as próximas aos rios e lagos maranhenses, envolvendo nelas embarcações, inclusive as artesanais.

\footnotetext{
${ }^{131}$ CAMPOS, Augusto de; Haroldo de. ReVisão de Sousândrade. Rio de Janeiro: Nova Fronteira, 1982. p. 397-398. ${ }^{132}$ Ibid.
} 


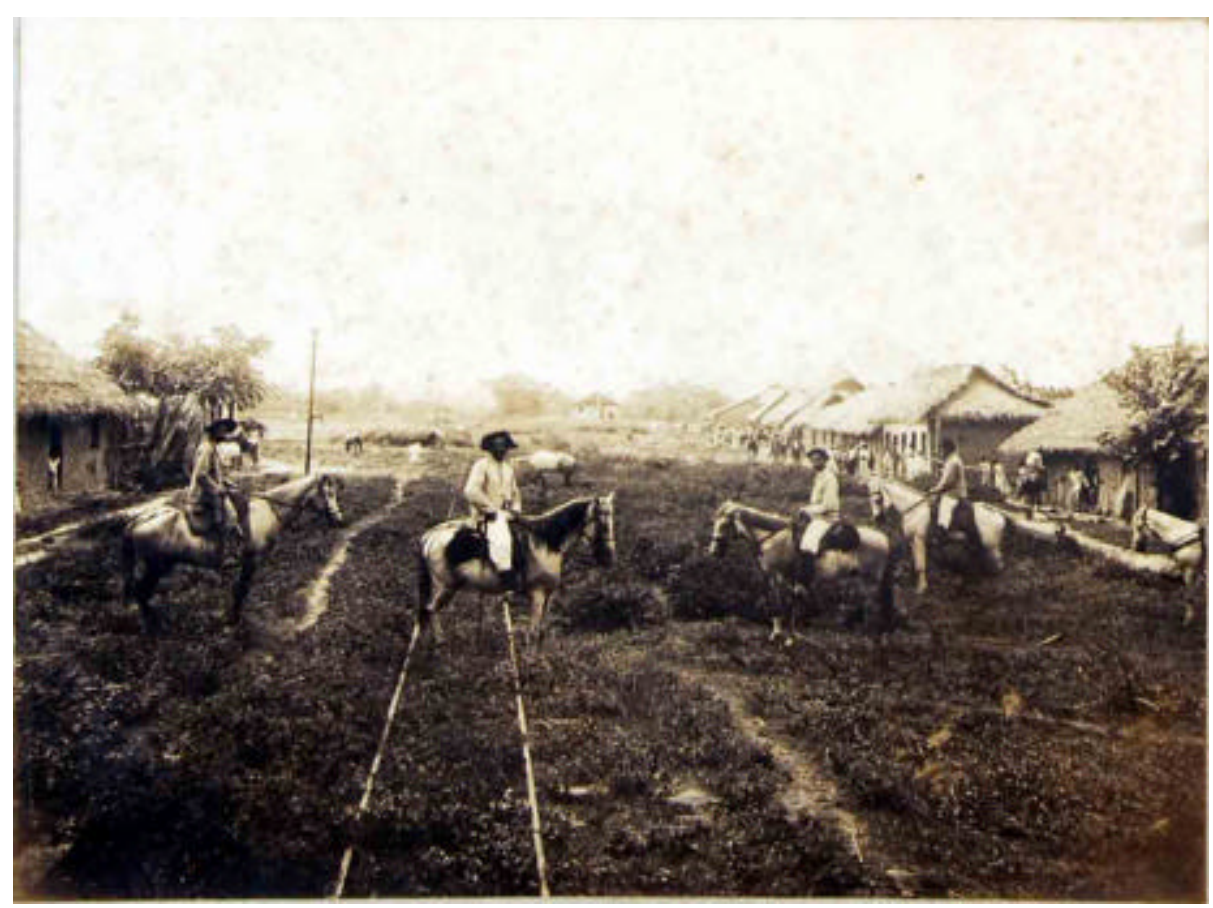

Fotografia 57 - Casas de taipa e palha na povoação Santa Ignez e os trilhos do Comple xo agroindustrial do Engenho Central, na Região do Vale do Pindaré. Album..., s.n.p., gelatina/prata, 14 x $19 \mathrm{~cm}$. MHAM.

Uma questão em particular é intrigante nas fotografias do interior: o fotógrafo deixa escapar a casa com paredes de taipa e cobertura de palha. Atualmente, há vínculos do ícone "casa de palha" com situações de miséria e até com visões ingênuas ligadas à tranqüilidade campestre, como a invocada na composição Casinha de palha do mineiro Beto Guedes. Porém, no tempo de Gaudêncio Cunha; 'casa de palha' contrastava com as idéias de progresso. Então por que incluí-las? Até a Revista do Norte destaca uma casa de palha na edição de 16 de fevereiro de 1902 com a legenda: Palhoça.

Algumas casas de palha, no álbum de 1908, estão próximas aos trilhos de um complexo açucareiro do Vale do Pindaré denominado Engenho Central de São Pedro (Fotografia 57) ${ }^{133}$. Na mesma imagem, os trilhos do Engenho Central de Pindaré perecem anunciar a chegada do progresso em uma área onde as habitações são rústicas. Seria esse o objetivo de Gaudêncio Cunha ao incluir trilhos e casas de palha na mesma fotografia? É como se os trilhos dissessem que, em breve, tudo pode mudar e os imóveis serem construídos em alvenaria, como era a usina.

Na mesma fotografia, de parte do comple xo da Usina do Vale do Pindaré, há cavalos próximos aos trilhos. É a força animal ao lado da velocidade moderna inserida nas plantações de cana-de-açúcar. O transporte mecânico elimina a capacidade do cavalo, de

\footnotetext{
${ }^{133}$ Ver sobre o Engenho São Pedro em (VIVEIROS, 1992, 2-3; 1954, p. 208).
} 
transportar a cana-de-açúcar. O cavalo, apesar de ainda transmitir áurea de poder aos seus usuários, aparece mais como transporte de uso pessoal, ou até mesmo como de recreação. $\mathrm{O}$ que interessa na fotografia é que a modernidade dos trilhos se une à tradicional lavoura da cana-de-açúcar, trazendo o progresso, mas sem alterar as estruturas de poder.

Gaudêncio Cunha fotografou, também, as embarcações, que interligavam São Luís às cidades do interior (Fotografias 1 e 2). As embarcações e as navegações são assuntos que ainda precisam ser explorados com mais profundidade, considerando que, em boa parte do século XX, a navegação fluvial era o meio de transporte mais importante no Maranhão, uma região de grandes rios. Os historiadores vêm tocando nesse tema, mas, eles se voltam mais para aspectos políticos e econômicos. Viveiros ${ }^{134}$ tem informações pontuadas aqui e ali em suas publicações ${ }^{135}$ e Flávio Reis ${ }^{136}$ detalha alguns aspectos da navegação a vapor, costeira e fluvial, no século XIX e início do século $\mathrm{XX}^{137}$.

Ainda, há pouco interesse sobre os aspectos culturais e a vida cotidiana envolvendo as embarcações e navegações pelos rios e mares brasileiros. O que fazia as pessoas, horas a fio, dentro das embarcações pelos rios e costa maranhense, em meio a chuvas intermináveis?

Fora do mudo acadêmico, alguns escritores rebuscaram, através de suas memórias de infância, viagens que vivenciaram pelos rios maranhenses. Ribamar Martins ${ }^{138}$ rememora os tempos em que viajou em lanchas pelo Rio Mearim ${ }^{139}$. Lembra das embarcações de seu tio, José de Jesus Mendes Martins e dos comandantes das navegações fluviais, como Antônio Fernandes. Assim como ele, alguns outros escreveram sobre suas lembranças de embarcações, mas sempre fora do mundo acadêmico. As embarcações e navegações maranhenses ainda não foram estudadas no campo da história cultural. Com era a vida dos passageiros e dos tripulantes durante as viagens? E os naufrágios?

\footnotetext{
${ }^{134}$ VIVEIROS, Jerônimo de. História do Comercio do Maranhão 1612 - 1895. $1^{\text {o }}$ Volume. São Luís: Associação Comercial do Maranhão/Oficinas Gráficas do Jornal do Brasil, 1954.

${ }^{135}$ Ibid., p. 255-266.

${ }^{136}$ REIS, Flávio. Grupos políticos e estrutura oligárquica no Maranhão. São Luís: Unigraf, 2007.

137 Ibid., p. 172-181.

${ }^{138}$ MARTINS, José Ribamar. São Luís era assim. Relembrando lanchas e o Mearim. Brasília: Equipe, 2007.

${ }^{139}$ Ibid., p.83-87.
} 


\subsection{O toque do artista}

\subsubsection{A Rua do Giz}

Observe a fotografia da Rua 28 de julho - ou Rua do Giz (Fotografia 58) como chegou a ser denominada -, criada por Gaudêncio Cunha. A via é longa, estreita e um pouco torta. Encontra-se emoldurada por imensos casarões com beirais, da fase Colonial/Imperial. As edificações parecem comprimir a rua.

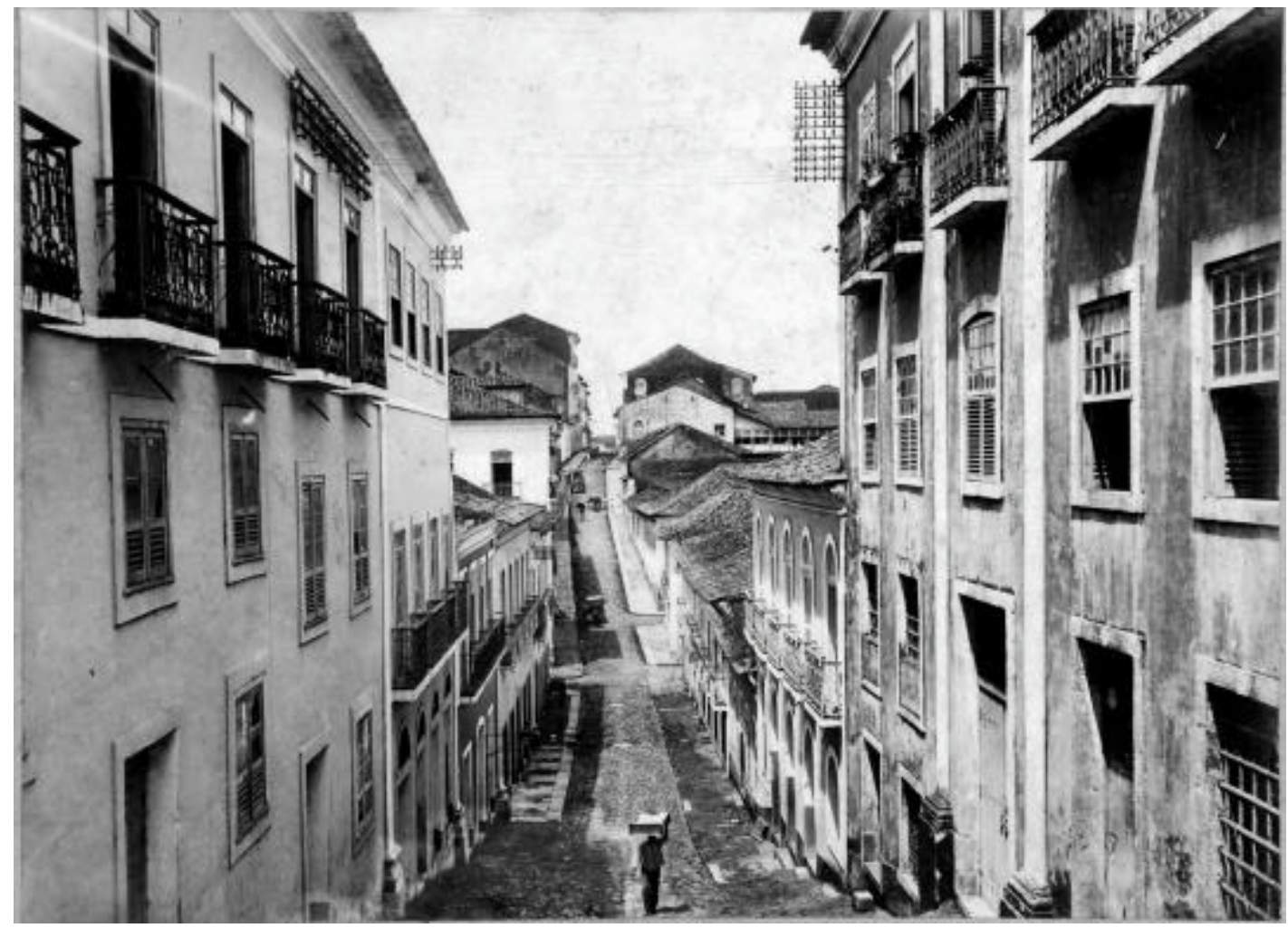

Fotografia 58 - Rua 28 de julho ou Rua do Giz. Album..., s.n.p., gelatina/prata, 14 x 19,5cm. MHAM.

No meio da rua, há um transeunte carregando uma mercadoria. É um personagem mais revestido de aparências campestres do que urbanas. Lembra imagens de pessoas legendadas no álbum Maranhão Ilustrado, de 1999/1900 ${ }^{140}$ com o nome de costumes. O transeunte da Rua Giz retratado por Gaudêncio Cunha pode até ser um pregoeiro, como se

\footnotetext{
${ }^{140}$ Em uma fotografia há um senhor, descalço, carregando um cofo, em uma área rural, mas próxima a um trilho. Na segunda fotografia há duas pessoas montadas em um burro, com um cofo ao lado, também em uma área rural. Cofo é uma sacola feita de palha de coqueiro. No álbum, as duas fotografias estão legendadas como: costumes. As mesmas fotografias foram publicadas, posteriormente, na Revista do Norte de $1^{\circ}$ de outubro de 1902. A do senhor com o cofo perto do trilho traz a seguinte legenda: Os typos populares maranhenses de volta a cidade. A das duas pessoas no burro é assim legendado: Os tipos maranhenses em caminho da maioba. Ver: FONTES, álbum 1.
} 
chama no Maranhão, os vendedores de rua que anunciam suas iguarias quase cantando. Podia ser um transportador de produtos da área de armazéns que ficava nas proximidades dessa rua ou, ainda, um homem que fazia serviços domésticos.

Cunha incluiu na fotografia pelo menos um item moderno. São os suportes de serviços telefônicos ou telegráficos colados na fachada lateral de uma das edificações. Os demais conteúdos, em sua maioria remetem ao passado.

Um pouco ao fundo, ainda há algo parecido com uma carroça. Há uma janela de sacada aberta que mostra a escuridão interna de um casarão, em meio à fachada branca do imóvel; uma pessoa encontra-se em uma outra sacada do mesmo casarão; há uma escada de madeira esquecida em uma das calçadas da rua.

Outros detalhes de composição, e até técnicos, podem ser identificados na fotografia, como sombras e enquadramentos. Contudo, apesar de ser uma paisagem essencialmente urbana, há elementos do meio rural, como o homem de costumes.

No geral, a tessitura predominante na fotografia é composta de elementos do passado, como é o caso dos velhos casarões e seus beirais. Como um conjunto de notas mais freqüentes na harmonia de uma peça musical, o antigo forma a extensão tônica.

Viajantes como Luiz Agassiz e Elizabeth Cary Agassiz ${ }^{141}$ e Annibal Amorim ${ }^{142}$ provavelmente viram nessa rua torta e estreita um ranço de antigüidade. $\mathrm{O}$ mesmo pode ter acontecido na Exposição de 1908, se alguém comparasse a Rua do Giz com a larga Avenida Rio Branco (Rio de Janeiro) recém-instalada pelo prefeito Pereira Passos ${ }^{143}$.

Se a Rua do Giz não era uma fotografia que acentuava conteúdos modernos, porque incluí-la em um álbum destinado à exposição de 1908 que privilegiou a modernidade? Poderia haver várias respostas. Mas, certamente, há três questões interligadas.

A primeira é a parcela de intervenção pessoal do fotógrafo, independente do que almejava o seu cliente. A segunda é que havia no Maranhão da época a mentalidade saudosista, voltada ao tempo áureo que teria ocorrido no século XIX, dentro dos campos da erudição e da economia. E vale lembrar que, por mais que remonte ao antigo, a Rua do Giz é uma paisagem de feições européias, bem-vindas em um país que desejava cultuar essa imagem para si. Gaudêncio uniu esses pontos e criou a imagem.

\footnotetext{
141 AGASSIZ, Luiz; AGASSIZ, Elizabeth C. Viagem ao Brasil 1865-1866. São Paulo: Companhia Editora Nacional, 1938.

${ }^{142}$ AMORIM, Annibal. Viagens pelo Brazil.Do Rio ao Acre - Aspectos da Amazônia - do Rio a Matto Grosso. Rio de Janeiro: Livraria Garnier, 1917.

${ }^{143}$ Há uma fotografia da larga Avenida Rio Branco, no Rio de Janeiro, no álbum em que estão os cartões postais da Exposição. Museu de Artes Visuais. Anexo Álbum 4.
} 
De forma alguma há intenção de se fazer uma avaliação estético-artística da fotografia da Rua do Giz ou de qualquer outra do álbum de 1908. Mas, tornou-se irresistível olhar algumas imagens utilizando as idéias do historiador da arte Francastel ${ }^{144}$. A tentação é valida, pois, as fronteiras que delimitam o que é arte e o que é razão às vezes se mostram imperceptíveis, como deixa transparecer Ivan Gaskell ${ }^{145}$ nas considerações que faz sobre a interpretação dos materiais visuais.

Francastel $^{146}$ enfatiza que a arte não é nunca toda submissa, mesmo de encomenda. "Pelo fato do artista trabalhar para um comanditário, ele não desposa todos os seus interesses nem seus pontos de vista sociais". Essa situação, acentuada diversas vezes por ele, se encaixa no caso de Gaudêncio Cunha e do álbum de 1908. Gaudêncio Cunha, em alguns momentos, parece contradizer as pretensões do governador Benedicto Leite.

Assim, considerando o pensamento de Francastel $^{147}$, o fotógrafo, mesmo buscando atender a encomenda de um cliente, expressa no álbum de 1908 um pensamento corrente em seu tempo e lugar que pode não corresponder totalmente ao que almejava o poder institucionalizado.

A visão de Gaudêncio Cunha, apesar de 'particular', é conectada a um meio cultural e a um grupo social determinado. Francastel acentua, por diversas vezes, que "o objeto encarna o comportamento de uma época". Gaudêncio Cunha absorveu a influência de seu meio e isso transparece em sua obra,, contudo, não quer dizer que essa sua visão corresponda exatamente às pretensões do seu cliente.

A fotografia da Rua do Giz faz certos elementos entrarem em conexão, como afirma Kossoy ${ }^{148}$. Remetem “[...] a sensações que ultrapassam os conteúdos emáticos, levando-o a refletir sobre algo cuja presença pressentimos, mas que não está ali, fisicamente [...]". Como observou o próprio autor ${ }^{149}$, são reflexões que nada êm em comum com o punctum de Barthes.

Gaudêncio Cunha, como qualquer pessoa, tem a sua história e trajetória de vida pessoal. Ele veio do Pará para o Maranhão e tinha a fotografia como ofício. Quem poderia estar nessa mesma situação naquela época? Gregório Pantoja, o seu parceiro de ofício, tem essas mesmas características. Só que Gaudêncio Cunha, quando incluiu a Rua do Giz no Álbum de 1908, estava elaborando uma encomenda para um cliente especial. Só ele estava

\footnotetext{
144 FRANCASTEL, Pierre. A realidade figurativa. São Paulo: Perspectiva, 1993.

${ }^{145}$ GASKELL, I. História das Imagens. In: BURKE, Peter (org). A escrita da história. São Paulo: UNESP, 1992.

${ }^{146}$ FRANCASTEL, Pierre. A realidade figurativa. São Paulo: Perspectiva, 1993. p. 27.

${ }^{147}$ Ibid., p. 56.

${ }_{148}^{148}$ KOSSOY, Boris. Os tempos da fotografia: o efêmero e o perpetuo. Cotia: Ateliê Editorial, 2007. p. 150.

${ }^{149}$ Ibid., p.149.
} 
fazendo isso, apesar de contar com a ajuda de colaboradores. O que ele fz foi único e particular. Realizou algo que “[...] Quer a atenção, quer a investigação histórica, não enquanto objeto pensado, mas, pelo contrário, porque é o limite do pensável [...]"150.

A fotografia da Rua do Giz apresenta uma composição de conteúdo diferente do padrão moderno almejado na época. Poderia até ser excluída de um álbum para ser apresentado em uma exposição nacional que priorizava o progresso, o moderno da época. Contudo, a imagem revelou-se atraente para o fotógrafo. Ele optou em incluí-la na sua obra. Longe de um incômodo, a fotografia da Rua do Giz é irresistivelmente destacada.

\subsubsection{Influência da pintura na fotografia}

Estudiosos ligados à história da fotografia, como Peter Burke ${ }^{151}$ e Boris Kossoy, concordam que os fotógrafos incorporaram em suas atividades influências da pintura, em especial nos aspectos estéticos e de composição dos temas e ângulos das imagens. A influência é mais visível entre os primeiros fotógrafos, do século XIX até os do início do século XX. O uso de aspectos do mundo pictórico em trabalhos de fotógrafos que atuaram no Brasil já foi comprovado por estudiosos como Antonio Franceschi ${ }^{152}$ e Vânia Carvalho ${ }^{153}$. O mesmo acontece com paisagens da natureza que Gaudêncio Cunha fez do interior maranhense ${ }^{154}$.

Ainda há necessidade de pesquisar esse tema com mais profundidade, principalmente fora do eixo Rio/São Paulo. Nesse caso, as novas pesquisas terão de considerar fatores importantes como condições diferenciadas de incidência de luz nas diversas regiões do país, o que deve resultou em inúmeras variações em termos de composição estética das fotografias.

\footnotetext{
${ }^{150}$ LE GOFF, Jacques. Memória In: Enciclopédia Einaudi. Vol. I: Memória-História. Lisboa: Imprensa Nacional/Casa da Moeda, 1984. p.170.

${ }_{151}$ BURK, Peter. Testemunha ocular: história e imagem. Bauru:Edusc, 2004, p. 128; BURKE, Peter. A nova história, seu passado e seu futuro. In: BURKE, Peter (org.). A Escrita da História. Novas Perspectivas. São Paulo: UNESP, 1992, p. 27

${ }^{152}$ FRANCESCHI, Antonio F. Entre a fotografia e a pintura. In: O Brasil de Marc Ferrez. São Paulo: Instituto Moreira Salles, 2005, p. 98 107.

${ }^{153}$ CARVALHO, Vânia P. A representação da natureza na pintura e na fotografia brasileira do século XIX. In: FABRIS, Annateresa. Fotografia: usos e funções no século XIX. São Paulo: Edusp, 1998, p. 199-231.

${ }^{154}$ A circulação de pinturas de paisagens e de retratos era comum no século XIX e século XX em São Luís. Estavam presentes em decorações de imóveis residenciais e em exposições montadas com regularidade em estabelecimentos comerciais, instituições políticas e educacionais. (Ver: MELO, Luiz. Pintores maranhenses do século XIX. São Luís: Lithograf, 2002). Certamente, o mesmo acontecia em outras cidades brasileiras, como Belém, de onde veio Gaudêncio Cunha. Há exemplos de pinturas decorando imóveis em fotografias incluídas no próprio álbum de 1908. As imagens do Cutim podem ser comparadas, por exemplo, com a pintura "Sir Brooke Boothby lendo Roussseau", de Joseph Wright. Ver BURKE, Peter. Testemunha ocular. Bauru, Edusc, 2004, p. 125. Essa sugestão de comparação, de forma alguma propõe que a pintura de Wright tenha sido a que influenciou Gaudêncio Cunha. É um exemplo despretensioso citado aqui somente como forma comparativa.
} 
O trabalho de Gaudêncio Cunha certamente absorveu essa influência, pois ele tinha vários pintores entre seus amigos, incluindo Manoel Valente, que foi um dos seus colaboradores. O estilo de algumas fotografias incluídas no álbum apresenta um viés pictórico. Um exemplo são as que mostram o Cutim, nos arrabaldes de São Luís (Fotografias 59 e 60$)$.

Peter Burke ${ }^{155}$ acredita que a fotografia é, ao mesmo tempo, uma seleção do fotógrafo, de acordo com seus interesses, crenças, valores, preconceitos, entre outros fatores e tem "débito, consciente ou inconsciente, às convenções pictóricas".

A influência da pintura sobre a fotografia pode até não ser sempre tão visível nos estudos comparativos realizados por Antonio Franceschi e Vânia Carvalho e, com relação a Gaudêncio Cunha, apresentar-se mais como algo induzido e absorvido culturalmente por ele.

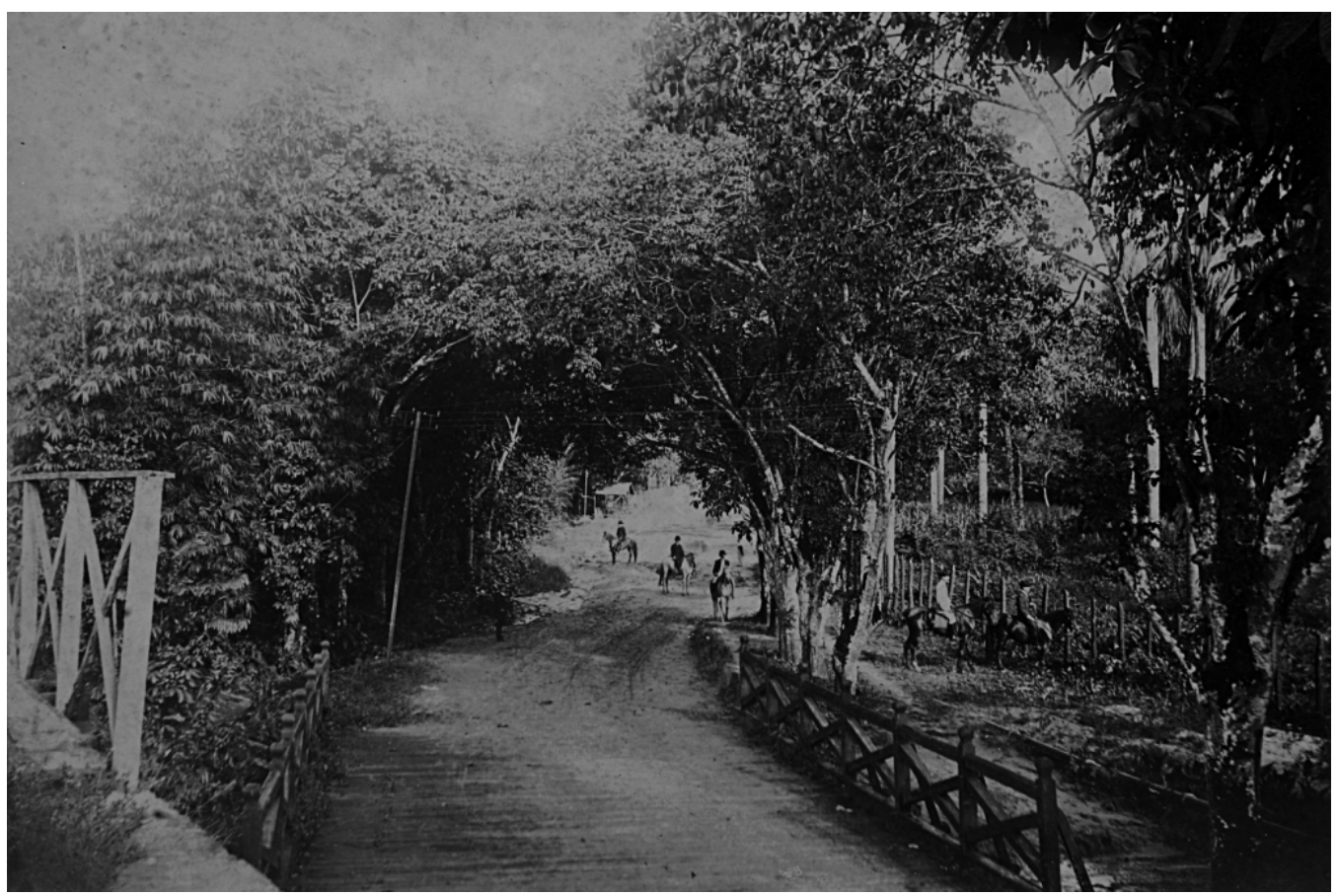

Fotografia 59 - Estrada do Cutim. Album..., s.n.p. gelatina/prata, 15 x $20 \mathrm{~cm}$. MHAM.

\footnotetext{
${ }^{155}$ BURKE, Peter. A Nova História, seu passado e seu futuro. In: BURKE, Peter (org.). A Escrita da História. São Paulo:
} UNESP, 1992, p. 27. 


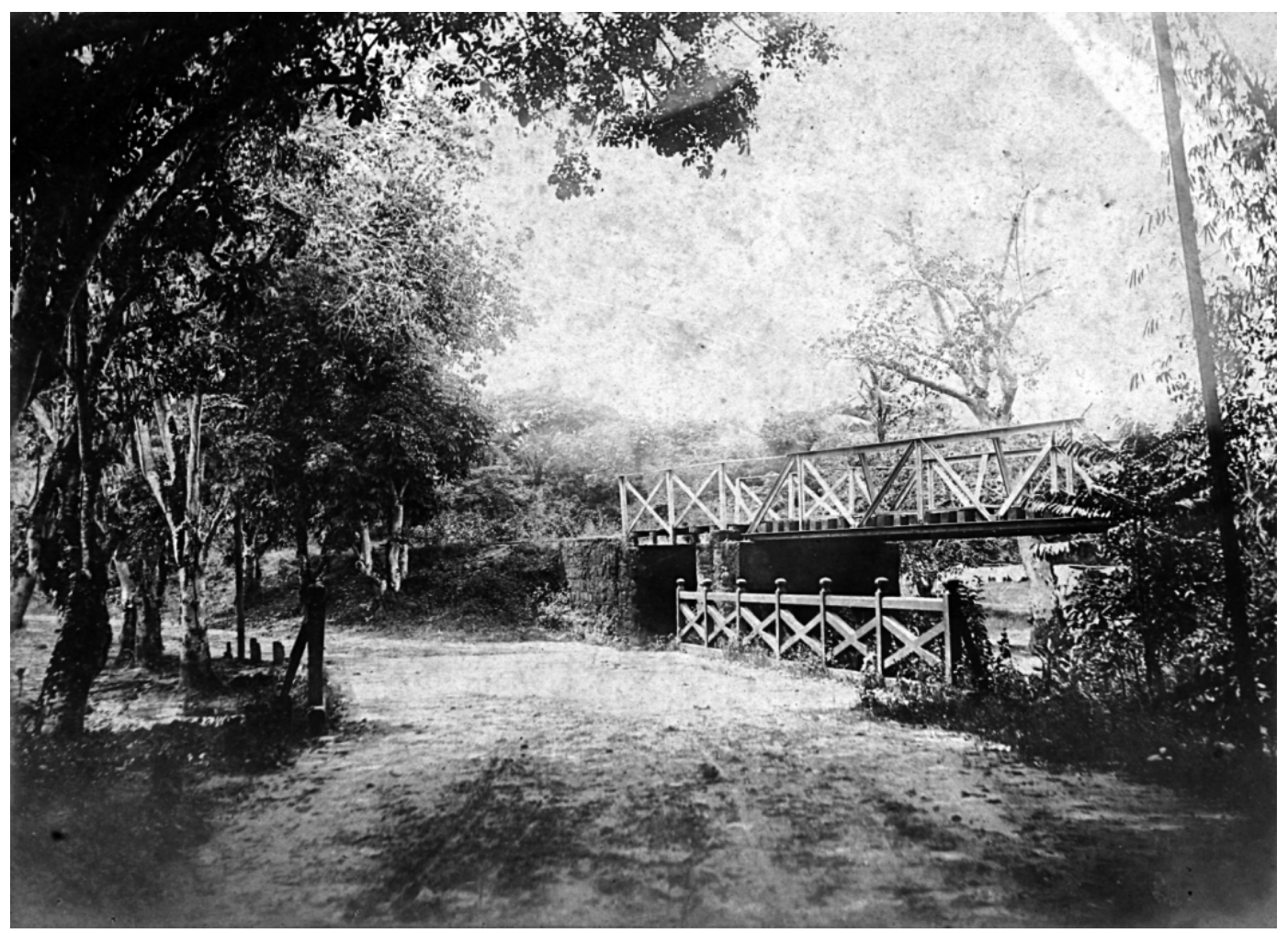

Fotografia 60 - Ponte da Via férrea no Cutim Album..., s.n.p. gelatina/prata, 15 x $20 \mathrm{~cm}$. MHAM.

Franceschi lembra que para Agostinho "[...] a imagem tem relações antinômicas entre memória e esquecimento [...]"156 . De forma que, consciente ou inconscientemente, os fotógrafos foram de maneira explícita ou velada, influenciados pela pintura.

De acordo com Franceschi ${ }^{157}$, há assimetrias entre as fotografias criadas por Marc Ferrez e as pinturas elaboradas pelo seu contemporâneo, o pintor Nocolò Facchinetti, que pintou paisagens do Rio de Janeiro. Uma das coincidências entre os trabalhos do pintor Facchinetti e Ferrez é a escolha do que Franceschi chama de pontos de vista ${ }^{158}$, que nada mais é que o local em que o criador de paisagens - pintor ou fotógrafo - se encontra na hora de buscar o ângulo desejado. No caso de Ferrez, há semelhanças entre alguns de seus trabalhos e os de Facchinetti.

Há uma fotografia no álbum de 1908 que tem como ponto de vista (local do fotógrafo no ato fotográfico) a área do São Francisco, de onde era possível se ter uma visão panorâmica da parte litorânea de São Luís que margeava a desembocadura do Rio Anil (Fotografia 61). A imagem é uma das primeiras do álbum. Ocupa toda uma página e encontrase entre as de maior tamanho. A legenda aponta como sendo o Porto de São Luís. Mas, o

\footnotetext{
${ }^{156}$ BURKE, Peter. O que é história cultural. Rio de Janeiro: Zahar, 2005, p.98.

${ }^{157}$ Ibid., 2005.

${ }^{158}$ Ibid., 2005, p.105-106.
} 
fotógrafo terminou apresentando mesmo foi uma panorâmica da cidade. Por causa de questões técnicas, ele inclui a imensidão do mar em destaque, deixando São Luís distante, ao fundo, como se estivesse perdida entre o céu e a imensidão da água.

Antes de Cunha elaborar a panorâmica de São Luís a partir da área do São Francisco, Manuel Ricardo Cauto (ou Couto?) fez uma litogravura da cidade em $1864^{159}$. Utilizou a Ponta do São Francisco, como ponto de vista. Tanto na litogravura como na fotografia os autores utilizaram o mesmo ponto de vista para criar panorâmicas de São Luís.

É incerta a possibilidade de Cunha ter conhecido a litogravura elaborada por Cauto. Até porque, a Coleção de Gravuras de Artur Azevedo, da qual a obra faz parte, só chegou ao Maranhão em 1910. Mesmo assim, essa possibilidade não é de toda descartável, já que, no meio em que o autor do álbum de 1908 vivia, circulavam muitos debates e informações sobre pinturas e gravuras.

Cunha e Artur Azevedo colaboraram com a Revista do Norte. Pintores e fotógrafos da época que moravam em São Luís interagiam através da Tipográfica Gaspar Teixeira \& Irmão, responsável por vários serviços ligados à divulgação da arte, entre os quais a Revista do Norte. Essa empresa conectava informações entre pintores, fotógrafos e escritores. Publicou gravuras e fotografias vindas de vários outros estados. Mas, independente de Cunha ter visto ou não a litogravura, vale fazer a comparação da fotografia e da litogravura, até por causa das diferenças e assimetrias entre as duas iconografias.

\footnotetext{
${ }^{159}$ Os dados que se tem sobre a litogravura da panorâmica que Manoel Cauto fez de São Luís estão no próprio trabalho. Há uma legenda informando: "Maranhão. Cidade de S. Luiz. Vista da ponta de S Francisco, em 1864". A impressão é da Lemercier Deseine 57 Paris. De um lado há o nome do pintor, Miguel Cauto e do outro a informação: TH Muller FT Gluc. A gravura faz parte da Coleção Artur Azevedo, que reúne 18.413 peças, sendo boa parte gravuras do século XVI ao XIX. Em depoimento a José Reinaldo Castro Martins, em 5.6.2007, a curadora Helena Duboc (jornalista e historiadora da arte, com doutoramento na UFRJ, em 1989) informa que a coleção foi comprada pelo Governo do Maranhão, da viúva de Artur Azevedo, pelo Governo Luiz Dominguez, em 1910. Dessa forma foi possível que a coleção saísse do Rio de Janeiro para o Maranhão. Duboc denomina o trabalho de Cauto como uma brasiliana. É assim que são chamadas as gravuras de época que apresentam costumes e paisagens brasileiras. Ela informou que Manuel Cauto ainda fez gravuras de paisagens de Belém do Pará e de Maceió. A Coleção Arthur Azevedo, atualmente é parte da Curadoria de Bens Culturais do Governo do Maranhão. Encontra-se em um anexo do Palácio dos Leões, antigo Palácio do Governo e aual sede do Executivo Maranhense.
} 


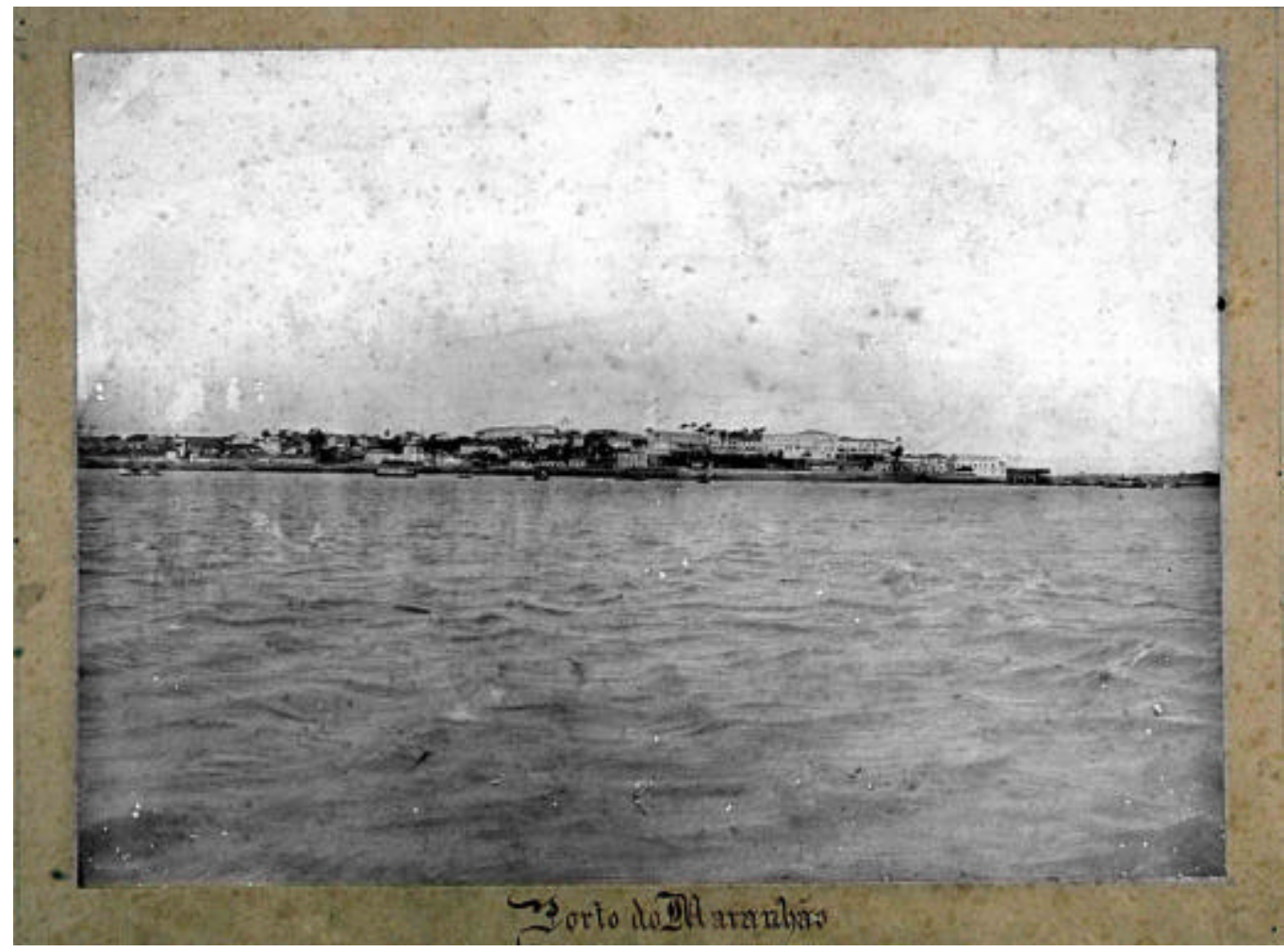

Fotografia 61 - Porto de São Luís, com mar em primeiro plano e panorâmica da cidade. Album..., s.n.p., gelatina/prata, $26,3 \times 36 \mathrm{~cm}$. MHAM.

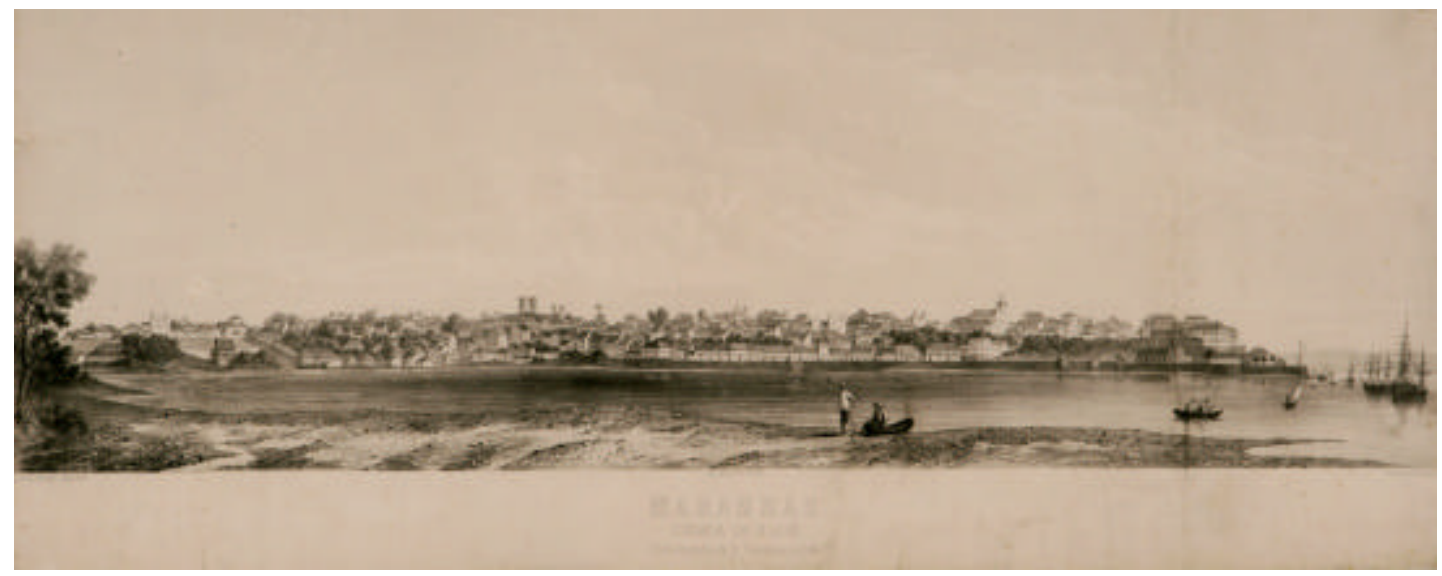

Ilustração 16 - Panorâmica de São Luís, com pescadores em primeiro plano. Tomada feita da Ponta do São Francisco. Litogravura de Miguel Cauto, 0,30.0 x 0,38.4; papel $0,36.3$ x 0,88.4. Coleção Artur Azevedo pertencente à Curadoria de Bens Culturais do Governo do Maranhão.

Mesmo a legenda fazendo referência ao porto, a fotografia criada por Cunha é uma panorâmica de São Luís. Fazer uma imagem ampla da cidade poderia fazer parte dos anseios dele. Seria uma idéia que, certamente, o acompanhava consciente ou 
inconscientemente, pois muitos pintores do século XIX criaram panorâmicas de centros urbanos.

Pela legenda, a intenção (ou justificativa) de Cunha era apresentar o Porto do Maranhão. O porto, na verdade, são as embarcações ancoradas próximas ao local de desembarque. Só que, apesar da legenda, a fotografia é uma panorâmica de São Luís. Já a gravura de Cauto, por sua vez, tinha mesmo como meta mostrar a panorâmica da capital maranhense.

$\mathrm{Na}$ fotografia feita por Cunha, a imensidão do mar aparece em primeiro plano, o que foi inevitável, pois a distância da área do São Francisco para a área urbana de São Luís chega perto de um quilômetro. As condições técnicas (ausências de lentes de aproximação, entre outras) não permitiam se fazer uma tomada mais próxima da cidade e das embarcações.

A litogravura de Manoel Cauto mostra São Luís mais próxima e, por isso, mais passível de se visualizar detalhes. É uma obra que ainda precisa ser estudada, através de pesquisas sobre o autor e sua época. Usando a litogravura, Manuel Cauto diminuiu a distância marítima existente entre a Ponta do São Francisco e São Luís. Ele ainda incluiu pescadores e se deu ao luxo de fazer algumas alterações na cidade.

Helena Duboc acredita que as torres da igreja de Santo Antônio estão fora de proporção dentro do contexto do trabalho. "É como se Manoel Couto tivesse querendo evidenciar as torres", propõe ${ }^{160}$. Há outros detalhes da cidade interessantes como os prováveis resquícios de um forte no local mais próximo do Palácio do Governo.

A panorâmica de São Luís apresentada por Cunha mostra uma cidade com algumas embarcações ao redor, principalmente ao lado esquerdo da fotografia, onde se localiza a rampa de desembarque. A cidade às vezes parece pequena, quase insignificante. É como se estivesse correndo o risco de ser tragada pelo mar turvo e bravio.

Por fim, dentro das relações entre qualquer fotografia e uma pintura, vale lembrar que a primeira, também, chegou a influenciar as representações plásticas do século XIX, como desenho e a pintura a óleo ${ }^{161}$. Algumas fotografias originaram litografias, como as incluídas na documentação realizada por Victor Frond ${ }^{162}$. Houve uma mútua influência que gerou tendências e inquietações.

\footnotetext{
${ }^{160}$ Depoimentos de Maria Helena Duboc concedidos a Jose Reinaldo Castro Martins em 5.6.2007 e em 3.12.2007. Ela foi diretora do Museu Histórico e Artístico do Maranhão na década de 1980, quando organizou uma exposição com reproduções das fotografias que compõem o álbum e curadora dos Bens Culturais do Palácio dos Leões (São Luís-MA).

${ }^{161}$ KOSSOY, Origens e expansão da fotografia no Brasil. Século XIX. Rio de Janeiro: MEC/Funarte, 1980. p. 78.

162 Ibid., p. 78.
} 
Na década de 1890, aconteceu inclusive um movimento em Londres em busca do que foi chamado de 'fotografia artística', envolvendo principalmente os chamados fotógrafos amadores de camadas mais abastadas da burguesia ${ }^{163}$, e a pintura era a referência.

${ }^{163}$ Ibid., p. 82-83. 


\section{CONSIDERAÇÕES FINAIS}

Ficou evidente que apesar do Album do Maranhão em 1908 ter sido uma encomenda elaborada com o fim específico de representar o Maranhão na Exposição Nacional de 1908, realizada no Rio de Janeiro, o fotógrafo imprimiu traços pessoais na obra.

É certo que ao compor e selecionar as imagens, ele se preocupou, primordialmente, em corresponder às pretensões de seu cliente, o Governo do Estado. Em alguns momentos, procurou acentuar signos aceitos como modernos em sua época. Fez isso, por exemplo, quando destacou trilhos dentro do conteúdo fotográfico (Fotografia 27). Ao proceder dessa maneira, ele atendeu a um espírito de seu tempo que considerava importante valorizar esses conteúdos.

Gaudêncio Cunha incluiu os aspectos modernos do início da fase republicana dentro da antiga paisagem urbana de São Luís, que remonta ao final do século XVIII e parte do século XIX. Era esse o cenário de aspecto europeu que havia no Maranhão. E as formas européias, mesmo contendo elementos do passado, podiam ser apresentadas na exposição como exemplo de civilidade.

Mesmo considerando as precauções tomadas por Gaudêncio Cunha para atender ao seu cliente, perpassou, afinal, a sensação de que ele, embora tenha vivido quase vinte anos dentro do século XX, foi um homem com idéias do século anterior. E essa característica incidiu na elaboração do álbum de 1908.

Gaudêncio Cunha, de certa maneira, identificourse com as paisagens urbanas de São Luís remanescentes do fim do século XVIII e do século XIX. Esse cenário se preservou pouco alterado até o início do século XX. E foi nesse espaço que o fotógrafo inseriu símbolos modernos que surgiram desde a segunda metade do século XIX e que permaneceram, no começo da República, como sendo novidades próprias do progresso.

As imagens antigas, como os velhos casarões e outras imagens que remontam à economia escravagista, como os jovens descalços trabalhando na porta dos armazéns, foram registradas nas fotografias do álbum de 1908, também, porque estavam constituídas na memória oitocentista de Gaudêncio Cunha. Era inerente à sua forma de observar o mundo.

A idéia de novidades pouco empolgou o fotógrafo, apesar de seu empenho em acompanhar as inovações em termos de tecnologias fotográficas lançadas no mercado. Nesse 
caso específico, a sua intenção era unicamente a de manter o seu negócio oferecendo um serviço de qualidade para os seus clientes.

No álbum de 1908, ele incluiu elementos da modernidade, porque esse era um imperativo que ele tinha de acompanhar. E nesse caso, ainda há outra questão a considerar: vários desses elementos valorizados como modernos no início da República já circulavam no tempo do Império. A própria fotografia é um exemplo evidente.

Apesar de aparentar certa introspecção, Gaudêncio Cunha foi um homem, ao mesmo tempo conservador e bem relacionado. Esses traços transparecem em sua vida particular e profissional. Na vida pessoal, cultivou e manteve relações familiares e de amizade duradouras. Gregório Pantoja, por exemplo, era amigo dele desde Belém e assim permaneceu até a morte de Cunha.

No campo profissional, Gaudêncio Cunha preservou as relações sociais que conquistou, através de seu trabalho. Cultivou importantes clientes, como o Governo do Estado, empresários e um bispo do Maranhão.

Por fim, considero que o autor do Album do Maranhão em 1908 e a cidade São Luís tinham algo em comum: traziam dentro de si traços marcantes do passado. Para Baudelaire, como lembra Le Goff ${ }^{1}$, as formas da cidade mudam mais depressa que o coração dos homens. Interessante que Le Goff, logo depois de citar Baudelaire faz o arremate: "ainda assim a continuidade se firma em algumas formas das cidades"2. No caso de Cunha e de São Luís, o coração e as formas se mantiveram e se casaram no álbum de 1908. O tempo passado, pulsante na cidade e dentro do homem definiram boa parte dos conteúdos fotográficos.

Paira nas imagens do Maranhão criadas por Gaudêncio Cunha a nostalgia de um passado que manteve fortes marcas nos contornos da cidade e no coração dos homens. $\mathrm{O}$ Album do Maranhão em 1908, apesar dos anseios em prol da imagem moderna, é aberto ao antigo. O velho é manifesto com pitadas de modernidade. Saudosa e provinciana, São Luís ganha contornos nostálgicos no alvorecer do século XX. E essa, enfim, é a marca singela da criação deixada pelo autor em sua obra.

\footnotetext{
${ }^{1} 1988$, p. 143.

${ }^{2}$ LE GOFF, 1988, p. 143.
} 


\section{FONTES E REFERÊNCIAS}

\section{FONTES (DADOS COLHIDOS DURANTE A ANÁLISE TÉCNICO-ICONOGRÁFICA)}

1. Álbuns fotográficos do século XIX e da primeira metade do século XX

\begin{tabular}{|l|l|}
\hline \multicolumn{2}{|c|}{ Álbum 1 } \\
\hline Nome do álbum & Maranhão Ilustrado \\
\hline Fotógrafo (s) & Gaudêncio Cunha (provável autor) \\
\hline Tamanho & $8,4 \mathrm{~cm}$ \\
\hline Data/ano & $1899 / 1900$ \\
\hline Localização & $\begin{array}{l}\text { Instituto Histórico e Geográfico do } \\
\text { Brasil (Rio de Janeiro) }\end{array}$ \\
\hline Dados da Trajetória & Impresso na Alfaiataria Teixeira \\
\hline $\mathrm{N}^{\circ}$. de Páginas & 110 \\
\hline \multicolumn{2}{|c|}{ Fotografias do álbum } \\
\hline $\begin{array}{l}\text { Fotografias originais ou } \\
\text { reproduções fotográficas ou } \\
\text { Impressas? }\end{array}$ & Reproduções fotográficas impressas \\
\hline $\mathrm{N}^{\circ}$. de fotografias & \\
\hline Tamanho das fotografias & 9x5, a maioria \\
\hline Representações fotográficas & Paisagens urbanas de São Luís \\
\hline
\end{tabular}




\begin{tabular}{|c|c|}
\hline \multicolumn{2}{|r|}{ Álbum 2} \\
\hline Nome do álbum & Álbum do Maranhão (BRASIL) \\
\hline Fotógrafo (s) & Não Identificado (s) \\
\hline Tamanho & $17 \times 23 \mathrm{~cm}$ \\
\hline Data/ano & $1904 *$ \\
\hline Localização• & $\begin{array}{l}\text { Museu de Artes Visuais do Maranhão } \\
\text { (anexo do Museu Artístico do Maranhão) }\end{array}$ \\
\hline $\begin{array}{l}\text { Dados gerais } \\
\text { Trajetória }\end{array}$ & $\begin{array}{l}\text { Impresso na Tipografia Teixeira \& Irmãos Succrsma. Há uma } \\
\text { assinatura em caneta de tinta vermelha do historiador maranhense } \\
\text { Dunshee de Abranches (1867-1941) e uma dedicatória de sua filha, } \\
\text { a condessa Pereira Carneiro ao Museu do Maranhão. }\end{array}$ \\
\hline $\mathrm{N}^{\circ}$. de páginas & 25 \\
\hline \multicolumn{2}{|r|}{ Fotografias do álbum } \\
\hline $\begin{array}{l}\text { Fotografias originais } \\
\text { ou reproduções } \\
\text { fotográficas ou } \\
\text { Impressas? }\end{array}$ & Reproduções fotográficas impressas e colorizadas \\
\hline $\mathrm{N}^{\circ}$. de fotografias & 23 \\
\hline $\begin{array}{l}\text { Tamanho das } \\
\text { Fotografias }\end{array}$ & A maioria na dimensão $14 \times 9 \mathrm{~cm}$ \\
\hline $\begin{array}{l}\text { Representações } \\
\text { Fotográficas }\end{array}$ & $\begin{array}{l}\text { Fotografias pintadas de paisagens urbanas, ribeirinhas e rurais de } \\
\text { São Luís. }\end{array}$ \\
\hline
\end{tabular}

* O ano é resultado de pesquisa realizada pelo escritor e historiador Jomar Moraes. (ABRANCHES, Dunshee. A esfinge de Grajaú. São Luís: Alumar/Lithograf, 1993, p. 82). 


\begin{tabular}{|l|l|}
\hline \multicolumn{2}{|c|}{ Álbum 3 } \\
\hline Nome do álbum & Album do Maranhão em 1908 \\
\hline Fotógrafo (s) & Gaudêncio Cunha \\
\hline Tamanho & 58 x $42 \mathrm{~cm}$. \\
\hline Data/ano & 1908 \\
\hline Localização & $\begin{array}{l}\text { Museu Histórico e Artístico do } \\
\text { Maranhão (São Luís). }\end{array}$ \\
\hline Dados da Trajetória & $\begin{array}{l}\text { Elaborado na Photographia União, em } \\
\text { São Luís no início do século XX. } \\
\text { Integra, hoje, o acervo do MHAM. }\end{array}$ \\
\hline No. de Paginas & 100 \\
\hline $\begin{array}{l}\text { Fotografias originais ou } \\
\text { reproduções fotográficas } \\
\text { Impressas? }\end{array}$ & Fotografias originais \\
\hline No de fotografias & 211 \\
\hline Tamanho das fotografias & $\begin{array}{l}\text { Vários tamanhos, sendo a maioria. Em } \\
15 x 20 .\end{array}$ \\
\hline Representações fotográficas & Paisagens urbanas de São Luís \\
\hline
\end{tabular}




\begin{tabular}{|c|c|}
\hline \multicolumn{2}{|r|}{ Álbum 4} \\
\hline Nome do álbum & Sem nome \\
\hline Fotógrafo (s) & Não identificado (s) \\
\hline Tamanho & $29,4 \times 23 \mathrm{~cm}$ \\
\hline Data/ano & Década de 1910 \\
\hline Localização & $\begin{array}{l}\text { Museu de Artes Visuais do Maranhão } \\
\text { (anexo do Museu Histórico e Artístico do Maranhão) }\end{array}$ \\
\hline $\begin{array}{l}\text { Dados gerais } \\
\text { Trajetória }\end{array}$ & $\begin{array}{l}\text { Sem informação. Provavelmente peça de um conjunto de } \\
\text { documentos que o Governo do Maranhão adquiriu junto } \\
\text { aos herdeiros do historiador José Ribeiro do Amaral } \\
(1853-1927) \text {. }\end{array}$ \\
\hline $\mathrm{N}^{\circ}$. de páginas & 40 \\
\hline \multicolumn{2}{|r|}{ Fotografias do álbum } \\
\hline $\begin{array}{l}\text { Fotografias originais ou } \\
\text { reproduções fotográficas ou } \\
\text { Impressas? }\end{array}$ & $\begin{array}{l}\text { Reproduções fotográficas impressas (no modelo cartão- } \\
\text { postal) }\end{array}$ \\
\hline $\mathrm{N}^{\mathrm{o}}$. de fotografias & 145 \\
\hline Tamanho das fotografias & Maioria na dimensão 14 x 9 cm \\
\hline Representações fotográficas & $\begin{array}{l}\text { Reúne } 32 \text { fotografias pintadas em forma de } \\
\text { cartão-postal dos prédios dos pavilhões da Exposição } \\
\text { Nacional de 1908, no Rio de Janeiro, onde o álbum } \\
\text { Maranhão } 1908 \text { foi exposto. Possui, também, dois } \\
\text { retratos: Miguel Calmon (Ministro da Indústria e Viação } \\
\text { do Governo Afonso Pena) e Antônio Olyntho dos Santos } \\
\text { Pires (presidente do Directório Executivo da Exposição } \\
\text { Nacional de 1908). Nele, ainda constam fotos-pinturas de } \\
\text { cidades fluminenses (Rio de Janeiro, Icarahy e Petrópolis); } \\
\text { de Pernambuco, Rio Grande do Norte e Ceará (áreas } \\
\text { urbanas e rurais). }\end{array}$ \\
\hline
\end{tabular}




\begin{tabular}{|c|c|}
\hline \multicolumn{2}{|r|}{ Álbum 5} \\
\hline Nome do álbum & $\begin{array}{l}\text { Album Commemorativo do } 3^{\circ} \text { Centenário de fundação da } \\
\text { Cidade de São Luiz, Capital do Estado do Maranhão. }\end{array}$ \\
\hline Fotógrafo (s) & Não identificado (s) \\
\hline Tamanho & $31,0 \times 22,4$ \\
\hline Data/ano & 1912 (evento fotografado) 1913 (impressão) \\
\hline Localização & $\begin{array}{l}\text { Museu de Artes Visuais do Maranhão (anexo do Museu } \\
\text { Histórico e Artístico do Maranhão) }\end{array}$ \\
\hline $\begin{array}{l}\text { Dados gerais } \\
\text { Trajetória }\end{array}$ & Impresso na Tipografia Teixeira, em São Luís. \\
\hline $\mathrm{N}^{\circ}$. de páginas & $\begin{array}{l}162 \text { (as páginas com fotografias só são ocupadas no verso e } \\
\text { somente algumas escritas possuem frente e verso) }\end{array}$ \\
\hline \multicolumn{2}{|r|}{ Fotografias do álbum } \\
\hline $\begin{array}{l}\text { Fotografias originais ou } \\
\text { reproduções fotográficas } \\
\text { ou Impressas? }\end{array}$ & Reproduções fotográficas impressas \\
\hline $\mathrm{N}^{\circ}$. de fotografias & 50 \\
\hline Tamanho das fotografias & $\begin{array}{l}\text { A maioria nas dimensões: } 14 \text { x } 20 \mathrm{~cm}, 13, \text { x } 18,5 \mathrm{~cm} . \\
\text { e } 19 \times 14,5 \mathrm{~cm}\end{array}$ \\
\hline $\begin{array}{l}\text { Representações } \\
\text { fotográficas }\end{array}$ & $\begin{array}{l}\text { Imagens da Exposição do Tricentenário: Solenidade de } \\
\text { abertura, produtos expostos, visitantes; paisagens de São Luís } \\
\text { e ambientes internos de vários imóveis, entre escolas e } \\
\text { hospitais. }\end{array}$ \\
\hline
\end{tabular}




\begin{tabular}{|c|c|}
\hline \multicolumn{2}{|r|}{ Álbum 6} \\
\hline Nome do álbum & Álbum do Estado do Maranhão \\
\hline Fotógrafo (s) & Não identificado (s) \\
\hline Tamanho & $25 \times 35 \mathrm{~cm}$ \\
\hline Data/ano & 1923 \\
\hline Localização & Setor de Obras Raras da Biblioteca Pública Benedito Leite \\
\hline $\begin{array}{l}\text { Dados gerais } \\
\text { Trajetória }\end{array}$ & $\begin{array}{l}\text { Impresso na Gráfica Amazônia, em Belém - PA. É uma } \\
\text { homenagem aos } 100 \text { anos de adesão do Maranhão à Independência } \\
\text { do Brasil. }\end{array}$ \\
\hline $\mathrm{N}^{\circ}$. de páginas & 64 \\
\hline \multicolumn{2}{|r|}{ Fotografias do álbum } \\
\hline $\begin{array}{l}\text { Fotografias originais } \\
\text { ou reproduções } \\
\text { fotográficas ou } \\
\text { Impressas? }\end{array}$ & Reproduções fotográficas impressas \\
\hline $\mathrm{N}^{\mathrm{o}}$. de fotografias & 314, sendo 53 em propagandas nas páginas finais. \\
\hline $\begin{array}{l}\text { Tamanho das } \\
\text { fotografias }\end{array}$ & $\begin{array}{l}\text { Dimensões variadas, sem boa parte das metragens: } 15 \text { x } 10 \mathrm{~cm} \text {; } \\
13,5 \text { x } 9 \mathrm{~cm} ; 14,5 \times 10 \mathrm{~cm} \text { etc. }\end{array}$ \\
\hline $\begin{array}{l}\text { Representações } \\
\text { fotográficas }\end{array}$ & $\begin{array}{l}\text { Imagens de paisagens e ambientes externos e internos de imóveis } \\
\text { de São Luís (aproximadamente metade das fotografias) e outras } \\
\text { cidades maranhenses. }\end{array}$ \\
\hline
\end{tabular}




\begin{tabular}{|c|c|}
\hline & Álbum 7 \\
\hline Nome do álbum & Sem nome \\
\hline Fotógrafo (s) & Não identificado (s) \\
\hline Tamanho & $31,5 \times 24,5 \mathrm{~cm}$ \\
\hline Data/ano & Década de 1930 \\
\hline Localização & $\begin{array}{l}\text { Museu de Artes Visuais do Maranhão } \\
\text { (anexo do Museu Histórico e Artístico do } \\
\text { Maranhão) }\end{array}$ \\
\hline $\begin{array}{l}\text { Dados gerais } \\
\text { Trajetória }\end{array}$ & $\begin{array}{l}\text { Há um selo que indica ter sido o corpo do álbum } \\
\text { comprado na papelaria Heitor Ribeiro, no Rio de } \\
\text { Janeiro (Rua da Quitanda, 90). }\end{array}$ \\
\hline $\mathrm{N}^{\circ}$. de páginas & $\begin{array}{l}63 \text { páginas (a página } 12 \text { é numerada, mas não } \\
\text { contém fotografias). }\end{array}$ \\
\hline \multicolumn{2}{|c|}{ Fotografias do álbum } \\
\hline $\begin{array}{l}\text { Fotografias originais ou } \\
\text { reproduções fotográficas ou } \\
\text { Impressas? }\end{array}$ & Fotografias originais \\
\hline $\mathrm{N}^{\circ}$. de fotografias & 219 \\
\hline Tamanho das fotografias & $12 \times 7,5 \mathrm{~cm} \mathrm{e} 14 \times 8,5 \mathrm{~cm}$ \\
\hline Representações fotográficas & $\begin{array}{l}\text { Imagens de paisagens urbanas das cidades de } \\
\text { Manaus (25 fotografias), Belém (20), São Luís } \\
\text { (30), Teresina (14), Fortaleza (12), Natal (18), } \\
\text { João Pessoa (22), Recife (17), Maceió (11), São } \\
\text { Salvador (20), Vitória (10) e Niterói (20). }\end{array}$ \\
\hline
\end{tabular}




\begin{tabular}{|c|c|}
\hline \multicolumn{2}{|r|}{ Álbum 8} \\
\hline Nome do álbum & $\begin{array}{l}\text { Estado do Maranhão: Vistas e Aspectos } \\
\text { De Diversos Municípios } 1940\end{array}$ \\
\hline Fotógrafo (s) & Não identificado (s) \\
\hline Tamanho & $36,8 \times 29,5$ \\
\hline Data/ano & 1940 \\
\hline Localização & $\begin{array}{l}\text { Museu de Artes Visuais do Maranhão (anexo do Museu } \\
\text { Histórico e Artístico do Maranhão) }\end{array}$ \\
\hline $\begin{array}{l}\text { Dados gerais } \\
\text { Trajetória }\end{array}$ & $\begin{array}{l}\text { Sem Informações no álbum ou no Museu. Há o seguinte } \\
\text { oferecimento indicativo de parte da trajetória: "Ao meu amigo } \\
\text { João. Da Nossa Terra". Juca. Não há informações no Museu } \\
\text { sobre sua doação. }\end{array}$ \\
\hline $\mathrm{N}^{\circ}$. de páginas & 48 \\
\hline \multicolumn{2}{|r|}{ Fotografias do álbum } \\
\hline $\begin{array}{l}\text { Fotografias originais ou } \\
\text { reproduções fotográficas } \\
\text { ou Impressas? }\end{array}$ & Fotografias originais \\
\hline $\mathrm{N}^{\circ}$. de fotografias & 240 \\
\hline Tamanho das fotografias & $\begin{array}{l}\text { A maioria nas dimensões: } 8 \text { x } 12 \mathrm{~cm} ; 6 \text { x } 9 \mathrm{~cm} ; 6 \text { x } 5,5 \mathrm{~cm} ; 11 \\
\text { x } 7 \mathrm{~cm}, 11 \text { x } 8 \mathrm{~cm} \text { e } 8 \text { x } 12 \mathrm{~cm}\end{array}$ \\
\hline $\begin{array}{l}\text { Representações } \\
\text { fotográficas }\end{array}$ & Fotografias de paisagens de cidades maranhenses \\
\hline
\end{tabular}




\begin{tabular}{|l|l|}
\hline \multicolumn{2}{|c|}{ Álbum 9 } \\
\hline Nome do álbum & $\begin{array}{l}\text { Fiação de Tecidos Camboa S/A } \\
\text { Modificações e Realizações } \\
\text { Período de 1939 a 1949 }\end{array}$ \\
\hline Fotógrafo (s) & Não identificado (s) \\
\hline Tamanho & 33,5 x $25 \mathrm{~cm}$ \\
\hline Data/ano & 1949 \\
\hline Localização & $\begin{array}{l}\text { Museu de Artes Visua is do Maranhão (anexo do Museu } \\
\text { Histórico e Artístico do Maranhão) }\end{array}$ \\
\hline $\begin{array}{l}\text { Dados gerais } \\
\text { Trajetória }\end{array}$ & $\begin{array}{l}\text { Doado ao Museu Histórico e Artístico do Maranhão pelo } \\
\text { ex-auxiliar da Fábrica Camboa, Augusto Aranha } \\
\text { Medeiros. }\end{array}$ \\
\hline No . de páginas & 24 \\
\hline \multicolumn{2}{|c|}{ Fotografias do álbum } \\
\hline $\begin{array}{l}\text { Fotografias originais ou } \\
\text { reproduções fotográficas ou } \\
\text { Impressas? }\end{array}$ & Fotografias originais \\
\hline No. de fotografias & 48 \\
\hline Tamanho das fotografias & Maioria na dimensão 12 x 17 cm \\
\hline Representações fotográficas & $\begin{array}{l}\text { Interior e fachadas externas da fábrica, berçário para os } \\
\text { filhos dos funcionários e Vila Operária Francisco Aguiar. }\end{array}$ \\
\hline
\end{tabular}




\begin{tabular}{|c|c|}
\hline \multicolumn{2}{|r|}{ Álbum 10} \\
\hline Nome do álbum & Álbum do Maranhão 1950 \\
\hline Fotógrafo (s) & $\begin{array}{l}\text { Dreyfus Azoubel, José Mendonça, J. Amorim e Manoel } \\
\text { Dutra . }\end{array}$ \\
\hline Tamanho & $23 \times 31,5 \mathrm{~cm}$ \\
\hline Data/ano & 1950 \\
\hline Localização & $\begin{array}{l}\text { Museu de Artes Visuais (ane xo do Museu Histórico e } \\
\text { Artístico do Maranhão) }\end{array}$ \\
\hline $\begin{array}{l}\text { Dados gerais } \\
\text { Trajetória }\end{array}$ & $\begin{array}{l}\text { Organizado pelo jornalista Miécio Jorge. Impresso na } \\
\text { Imprensa Oficial do Maranhão durante a gestão do } \\
\text { governador Sebastião Archer. }\end{array}$ \\
\hline $\mathrm{N}^{\circ}$. de páginas & 352 \\
\hline \multicolumn{2}{|r|}{ Fotografias do álbum } \\
\hline $\begin{array}{l}\text { Fotografias originais ou } \\
\text { reproduções fotográficas ou } \\
\text { Impressas? }\end{array}$ & $\begin{array}{l}\text { Reproduções fotografias Impressas, sendo algumas fotos } \\
\text { colorizadas. }\end{array}$ \\
\hline $\mathrm{N}^{\circ}$. de fotografias & $\begin{array}{l}491 \text { de paisagens e autoridades ligadas a São Luís e São José } \\
\text { de Ribamar; } 487 \text { de paisagens e autoridades de outros } \\
\text { municípios maranhenses, } 16 \text { de propagandas e uma do } \\
\text { jornalista Miécio Jorge, o elaborador do álbum. }\end{array}$ \\
\hline Tamanho das fotografias & $\begin{array}{l}\text { Dimensões variadas: } 20 \times 13 \mathrm{~cm}, 9 \times 17 \mathrm{~cm} \text {, } \\
16 \text { x } 10,5 \mathrm{~cm} ; 6 \times 9,5 \mathrm{~cm}, 14,6 \times 20 \mathrm{~cm} \text { etc. }\end{array}$ \\
\hline Representações fotográficas & $\begin{array}{l}\text { Retratos de autoridades e grupo de humanos (professores } \\
\text { religiosos, seminaristas, alunos, transeuntes em festas } \\
\text { populares) e de paisagens urbanas e rurais do Maranhão. }\end{array}$ \\
\hline
\end{tabular}


2 Crônicas sobre fotografias localizadas em jornais da segunda metade do século XIX e início do século XX arquivados no Setor de Obras Raras da Biblioteca Pública Benedito Leite (São Luís - MA).

a) Enaltece a invenção da fotografia, a sua influência nos domínios da arte e relata pontos de alterações de sua técnica, referindo-se a descobertas de Daguerre, Niepce, Wodgwood, entre outros. Publicador Maranhense: São Luís, 16 de agosto de 1953.

b) Uma pequena nota sobre a aplicação da photographia em seda. Pacotilha: São Luís, 07 de maio de1881.

c) Analisa a evolução da técnica fotográfica. Inicia com o seguinte questionamento: "comparamos os retratos dos nossos avós com os que tiramos hoje [...]”. O Paiz: São Luís, 21 de março de1889.

d) Analisa a evolução técnica da photographia: "a photographia, no ponto de vista a que chegou ultimamente, e muito digna de excitar admiração [...]”. Pacotilha: São Luís, 28 de janeiro de 1893.

e) Informa sobre o uso da photographia para registrar a temperatura dos fornos da casa da Moeda de Londres. Pacotilha: São Luís, de 09 de outubro de 1893.

f) Avisa que oficial do exército italiano obteve fotografias de objetos colocados a 18 quilômetros de distância. Regeneração: São Luís, 03 de abril de 1900.

g) Lamenta que "teoricamente reconhecida como possível desde muito tempo, a fotografia das cores ainda não deu, na prática, todos os resultados que são lícitos operar ou, pelo menos, desejar [...]”. Fala de avanços conseguidos na Filadélfia, onde o Sr. Ives conseguiu obter três imagens coloridas sobre as chapas. O Estado: São Luís, 31 de agosto de 1917. 
3. Jornais e revistas arquivadas na Biblioteca Pública Benedito Leite em que foram encontrados anúncios sobre atividades de fotógrafos no Maranhão no século XIX e primeira metade do século XX.

\section{Jornais}

OBS: Os jornais e a revista pesquisados são do século XIX e início do século XX e circularam em São Luís, Caxias e de outras cidades maranhenses. Integram o acervo do Setor de Obras Raras da Biblioteca Benedito Leite (São Luís-MA). Sobre jornais maranhenses que estão nesse setor ver (SILVA, Celeste. Jornais Maranhenses: 1821-1999. São Luís: SIOGE, 1981).

1. Pacotilha: 1881, 1883, 1888, 1891 e 1892, 1893, 1903, 1915, 19161919 e 1920.

2. A Tarde : 1915 .

3. Federalista: 1892, 1895, 1897 e 1899.

4. Jornal dos Artistas : 1909.

5. O Maranhão (de Caxias - MA): 1908.

6. Publicador Maranhense: 1846, 1947, 1853, 1855, 1856, 1857, 1858 e 1859.

7. Regeneração: 1899 e 1900.

8. Gazeta Caxiense (Caxias): 1894.

9. A Cruzada: 1892.

10. O Nacional: 1892.

11. Diário do Maranhão: 1854, 1897, 1900, 1901, 1906 e 1911.

12. Diário Oficial: 1900, 1908 e 1909.

13. O Jornal: 1915 e 1920.

14. O Estado: 1915.

2. Revista

- Revista do Norte: De setembro de 1901 até agosto de 1906. Typogravura Teixeira. São Luís-MA. 
4 - Mensagens encaminhadas pelo Governo do Maranhão ao Congresso Legislativo.

1. 1 MARANHÃO. Mensagem que o $\operatorname{Exm}^{\circ} \mathrm{Sr}$. Governador Benedicto Pereira Leite apresentou ao Congresso Legislativo do Maranhão, em 7 de fevereiro de 1907. Imprensa Official do Maranhão, 1907.

2. MARANHÃO. Mensagem que o $\operatorname{Exm}^{\circ}$ Sr. João Gualberto Torreão Costa apresentou ao Congresso Legislativo do Maranhão, em 13 de fevereiro de 1901. Imprensa Official do Maranhão, 1901.

5 - Depoimentos orais citados na pesquisa

1. Dreyfus Nabor Azoubel; fotógrafo aposentado, nascido em 1919. Entrevistado em junho de 2001

2. Ribamar Alves; fotógrafo aposentado; nascido em 1927. Entrevistado em julho de 2005

3. José Cordeiro da Rocha; fotógrafo aposentado; nascido em 1928. Entrevistado em julho de 2005

4. Francisco Antônio de Souza; fotógrafo aposentado; nascido em 1928. Entrevistado em julho de 2005.

5. Edgar Soares da Rocha; fotógrafo em atividade; nascido em 1942. Entrevistado em julho de 2006.

6. Custódia Campos da Costa; colecionadora de fotografias; nascida 1921. Entrevista em janeiro de 2006.

7. Luiz Melo; pesquisador. Entrevistado em junho de 2006.

8. Maria Helena Duboc; curadora e historiadora da arte. Entrevistada em junho de 2006 e em dezembro de 2007.

9. Luiz Phelipe Andrès; engenheiro. Entrevistado em maio de 2007. 


\section{REFERÊNCIAS}

1. Filmes

1. Fitzcarraldo (Fitzcarraldo). Alemanha/França, 1982. Duração: 2h37min. Direção e produção: Werner Herzog. Filmado no Brasil e no Peru. Com Klaus Kinski (1926-1991), Claudia Cardinale e José Lewgoy (1920-2003). Werner Herzog Filmproduktion (Alemanha), T.V. - R.F.A. (Alemanha) e Gaumont (França). Distribuição no Brasil: Gaumont do Brasil. Prêmio de Melhor Diretor no Festival de Cannes de 1982.

2. Sinfonia em quatro tempos. Brasil, 2004. (Dvd, 26'). Direção e roteiro: Eduardo Ferreira. Trabalho final da dissertação de Mestrado em Multimeios do Instituto de Artes da Unicamp, sob a orientação do Prof. Dr. Claudiney Rodrigues Carrasco.

2. Entrevista oral

Clodomir Pantoja; fotógrafo aposentado. Entrevistado na década de 1980 por técnicos do projeto "História da fotografia no Maranhão (1850-1950)", da Secretaria de Cultura do Maranhão/FUNARTE.

3. MONOGRAFIAS, TESES E DISSERTAÇÕES.

CALDEIRA, Ribamar. C José. Origens da Indústria no sistema agro-exportador maranhense (1875 / 1895). Estudo micro-sociológico da instalação de um parque fabril em região do Nordeste Brasileiro no final do século XIX. Tese (Doutorado) Departamento de Sociologia - Universidade de São Paulo, São Paulo, 1988.

FREHSE, Fraya. Vir a ser transeunte: civilidade e modernidade nas ruas da cidade de São Paulo (entre o início do século XIX e início do século XX). Tese (Doutorado em Antropologia) - FFLCH-USP, São Paulo, 2004.

PEREIRA, Rosa Claudia C. Paisagens urbanas: fotografia e modernidade na Cidade de Belém (1846-1908). Dissertação (Mestrado em História) - DEHIS-UFPA, Belém, 2006.

SILVA FILHO, José Oliveira da. Olhos de ver: a cidade entre as retóricas do visual e do escrito. Monografia de especialização. (Especialização em História do Maranhão) - CECEN-UEMA, São Luís, 2006.

THIELEN, Eduardo Vilela. Imagens da saúde no Brasil. Dissertação de mestrado em História. PUC/SP. São Paulo, 1992.

THEREZINHA de J. A. A Revolta dos balaios no Maranhão (1838-1841). Dissertação (mestrado de História), Departamento de História da Universidade Federal Fluminense, Rio de Janeiro, 1982. 


\section{LIVROS, ARTIGOS E ÁLBUNS}

ABRANCHES, Dunshee. A esfinge do Grajaú. São Luís: Alumar/Lithograf, 1993.

AGASSIZ, Luiz; AGASSIZ, Elizabeth C. Viagem ao Brasil 1865-1866. São Paulo: Companhia Editora Nacional, 1938.

ALMEIDA. Maria da C. P. Saúde pública e pobreza: São Luís na Primeira República. IN: COSTA, Wagner Cabral (org.). História do Maranhão: novos estudos. São Luís: Edufma, 2004, p. 231-264.

ALMEIDA. Maria das Graças de. A construção da verdade autoritária. São Paulo: Humanitas, 2001.

AMARAL, José R. O Maranhão Histórico. São Luís: Geia, 2003.

AMORIM, Annibal. Viagens pelo Brazil. Do Rio ao Acre - Aspectos da Amazônia do Rio a Matto Grosso. Rio de Janeiro: Livraria Garnier, 1917.

ANDRÉS, Luiz P; MOREIRA, Rafael; SILVA, Ronald Almeida. Centro histórico de São Luís - Maranhão - Brasil. Patrimônio Mundial. São Paulo: Audichromo/UNESCO/SEC-MA, 1998.

ARAÚJO, Maria R. História da Balaiada. São Luís, FUCMA/Arquivo Público do Maranhão, 2001.

ARRUDA, José J. A. A economia brasileira no fim da época colônia: a diversificação da produção, o ganho de monopólio e a falsa euforia do Maranhão. In: Revista de História. São Paulo: Serviço de Artes Gráficas - FFLCH/USP, 1989. p. 3-21.

ATHAYDE, Raimundo A. Pereira Passos. O reformador do Rio de Janeiro. Rio de Janeiro: Editora A Noite, 1941.

BALANDIER, Georges. O poder em cena. Coimbra: Minerva, 1999.

BARROS, Valdenira. Imagem do moderno em São Luís. São Luís: Unigraf, 2001.

BARTHES, Roland. A câmara clara. Rio de Janeiro: Nova Fronteira, 1984.

BENJAMIN, Walter. Obras Escolhidas III. Charles Baudelaire: um lírico no auge do capitalismo. São Paulo: Brasiliense, 1994.

BORGES, Maria Eliza Linhares. História \& fotografia. Belo Horizonte: Autêntica, 2005.

BRAGA, Pedro. O velho bonde. São Luís: Jornal O Estado do Maranhão, Caderno Alternativo (capa ou página 13), 20.4.1991. 
BRAUDEL, Fernand. História e ciências sociais. Lisboa: Presença, 1972.

Reflexões sobre a história. São Paulo: Martins Fontes, 2002.

BURGI, Sergio; KOHL, Stephan. O fotógrafo e seus contemporâneos: influências e confluências. In: O Brasil de Marc Ferrez. São Paulo: Instituto Moreira Salles, 2005, p. 58-71.

BURKE, Peter. O que é história cultural. Rio de Janeiro: Zahar, 2005.

Testemunha ocular: história e imagem. Bauru: Edusc, 2004.

A nova história, seu passado e seu futuro. In: BURKE, Peter (org.). A escrita da história. São Paulo: UNESP, 1992, p. 7-37.

CALDEIRA, R. C. J. O Maranhão na literatura dos viajantes do século XIX. São Luís: AML/SIOGE,1991.

CAMPOS, Augusto de; Haroldo de. ReVisão de Sousândrade. Rio de Janeiro: Nova Fronteira, 1982.

CARVALHO, José Murilo de. A formação das almas. São Paulo: Companhia das Letras, 2002.

CARVALHO. Vânia $P$. A representação da natureza na pintura e na fotografia brasileira do século XIX. In: FABRIS, Annateresa. Fotografia: usos e funções no século XIX. São Paulo: Edusp, 1998, p. 199-231.

CARVAlHO, Maria Michol Pinho de. Memória de Velhos Depoimentos. Volume III. São Luís: Lithograf, 1997.

CATROGA, Fernando. Memória, história e historiografia. Coimbra: Quartetos, 2001.

CERTEAU, Michel de. A escrita da história. Rio de Janeiro: Forense Universitária, 2002.

CHARTIER, Roger. História cultural: entre práticas e representações. Lisboa: Difel, 1988.

CHOAY, Françoise. A regra e o Modelo. São Paulo: Perspectiva, 1985.

CIDADES HISTÓRICAS INVENTÁRIO E PESQUISAS. SÃO LUÍS. Rio de Janeiro: IPHAN/Senado Federal, 2007.

CORREIA, Maria da Glória G. Nos fios da trama: quem é essa mulher? Cotidiano e trabalho do operariado feminino em São Luís na virada do século XX. São Luís: Edufma, 2006. 
CORRÊA, Rossini. Formação social do Maranhão: o presente de uma arqueologia. São Luís: SIOGE, 1993.

COSTA, Emília Viotti. Da Monarquia à República. São Paulo, UNESP, 1999.

D’ABBEVILlE, Claude. História da Missão dos Padres Capuchinhos na Ilha do Maranhão, e suas Circunvizinhanças. São Paulo: Siciliano, 2002.

DAOU, Ana Maria. Memória e Identidade Social: o 'Álbum da cidade' como representação da elite amazonense e da Manaus Antiga. In: Cadernos de Antropologia e Imagens. Rio de Janeiro: EDUERJ, 1995. Número 8, p. 65-78.

DUBOC, Maria Helena. Palácio dos Leões. São Luís: Governo do Maranhão, 2006.

DUBOIS, Philippe. O ato fotográfico. Campinas: Papirus, 2004.

D’VREUX, Yves. Viagem ao Norte do Brasil. São Paulo: Siciliano, 2002.

EDLER, Flávio Coelho. Boticas \& Farmácias. Rio de janeiro: Casa da palavra, 2006.

FOUCAULT, Michel. A ordem do discurso. São Paulo: Loyola, 2004.

FREHSE, Fraya. O tempo das ruas. São Paulo: Edusp, 2005.

FRANCASTEL, Pierre. A realidade figurativa. São Paulo: Perspectiva, 1993.

FRANCESCHI, Antonio F. Entre a fotografia e a pintura. In: O Brasil de Marc Ferrez. São Paulo: Instituto Moreira Salles, 2005, p. 98-107.

FREYRE, Gilberto. Casa grande \& senzala. 32 ed. Rio de Janeiro: Record, 1997.

Gilberto; PONCE DE LEON, Fernando; VASQUEZ, Pedro. O retrato brasileiro: fotografias da coleção Francisco Rodrigues, 1849-1920. Rio de Janeiro: FUNARTE/Fundação Joaquim Nabuco, 1983.

GASKELL, I. História das imagens. In: BURKE, Peter (org). A escrita da história. São Paulo: UNESP, 1992, p. 237-271.

GINZBURG, Carlo. Sinais: raízes de um paradigma indiciário. In: Mitos, emblemas e sinais. São Paulo: Companhia das Letras, 2003, p. 143-179.

HALLEWEEL, Laurence. O Livro no Brasil. São Paulo: EDUSP, 1985, p. 93-110.

HAROUEL, Jean-Lous. História do Urbanismo. Campinas: Papirus, 1990.

JANOTTI, Maria de L. M. A Balaiada. São Paulo, Brasiliense, 1991.

KOYRÉ, Alexandre. Estudo de história do pensamento científico. São Paulo: Forense, 1991. 
KOSSOY, Boris. Os tempos da fotografia: o efêmero e o perpetuo. Cotia: Ateliê Editorial, 2007.

Hercules Florence 1833: a descoberta isolada da fotografia no Brasil. 3.ed.

São Paulo: Edusp, 2006.

Luzes e sombras da metrópole: um século de fotografias em São Paulo (1850-1950). In: PORTA, Paula. História da Cidade de São Paulo. A Cidade no Império 1823-1889. São Paulo: Paz e Terra, 2004a, v.2, p. 385-455.

Construção e desmontagem da informação fotográfica: teoria e história. Revista USP, n. 62, p. 224-232, jun./ago. 2004b.

Fotografia e história. 3. ed, São Paulo: Ateliê Editorial, 2003.

Dicionário histórico-fotográfico brasileiro: fotógrafos e ofício da fotografia (1833-1910). São Paulo: Instituto Moreira Salles, 2002.

Realidades e ficções na trama fotográfica. São Paulo: Ateliê Editorial, 2000.

Militão Augusto de Azevedo e a documentação fotográfica de São Paulo (1862-1887): recuperação da cena paulista através da fotografia. São Paulo: FESP, 1988 a. $1988 b$.

São Paulo 1900. Imagens de Guilherme Gaensly. São Paulo: Kosmos/CBPO,

Origens e expansão da fotografia no Brasil. Século XIX. Rio de Janeiro: MEC/Funarte, 1980.

Militão Augusto Azevedo e a documentação fotográfica de São Paulo

(1862-1887): recuperação da cena paulista através da fotografia São Paulo: FESP, 1988a.

LACROIX, Maria de Lourdes L. A Fundação francesa de São Luís e seus Mitos. São Luís: Lithograf, 2002.

LE GOFF, Jacques. Por Amor às cidades. São Paulo: UNESP, 1988.

Jacques. Memória In: Enciclopédia Einaudi. Vol. I: Memória-História. Lisboa: Imprensa Nacional/Casa da Moeda, 1984, p.158-259.

LEITE. Miriam Moreira. Retratos de família. São Paulo: EDUSP/ FAPESP, 2001.

LIMA, Carlos. Caminhos de São Luís. São Paulo: Siciliano, 2002. 
LIMA, Solange Ferraz. O círculo social da fotografia: estudo de caso II. In: FABRIS, Annateresa. Fotografia: usos e funções no século XIX. São Paulo: Edusp, 1998, p. 5982.

LISBOA, João F. A Festa de Nossa Senhora dos Remédios. São Luís: Editora Legenda, 1992.

LLOYD, Christopher. As estruturas da história. Rio de Janeiro: Jorge Zahar, 1995.

LOPES, José A. V. Os intelectuais e a preservação do patrimônio cultural de São Luís. In: PONTUAL, V; CARNEIRO, A. R. S. História e Paisagem: ensaio urbanístico do Recife e de São Luís. Recife: Bagaço, 2005, p. 339-370.

MAGALHÃES, Domingos J. G. Memória histórica e documentada da Revolução da província do Maranhão. São Paulo, Siciliano, 2001.

MAGNÓLIA, S. B. Índice tipográfico do centro histórico de São Luís. São Luís: Imprensa Universitária/UFMA, 1990.

MÁRQUEZ, Gabriel Garcia. O Amor nos Tempos de Cólera. Rio de Janeiro: Record, 2001.

MÁRQUEZ, Gabriel. Cem anos de solidão. Rio de Janeiro: Sabiá/Vozes, 1972.

MARTINS. José Ribamar. São Luís era assim. Relembrando lanchas e o Mearim. Brasília: Equipe, 2007.

MARTINS, Manoel B. Operários da Saudade : os novos atenienses e a invenção do Maranhão. São Luís: Edufma, 2006.

MARTINS, Ana Luiza. O despertar da República. São Paulo: Contexto, 2001.

MARTIN, Marcel. A linguagem cinematográfica. São Paulo, Brasiliense, 2003.

MATOS, Marcos F. ...E o Cinema Invadiu Athenas : história do cinema ambulante em São Luís. São Luís: Faculdade São Luís-UNISÃOLUÍS, 2002.

MEIRELES, Mário. História do Maranhão. 3. ed. atual. São Paulo: Siciliano, 2001.

MELO, Luiz. Cronologia das artes plásticas no Maranhão (1842-1930). São Luís: Lithograf, 2004.

Pintores Maranhenses do século XIX. São Luís: Lithograf, 2002.

AML/Alumar/Lithograf, 1999. 
MENDONÇA Edinamária C. Representações sociais em fatos culturais: o Álbum Commemorativo do $3^{\circ}$ Centenário da Fundação da Cidade de São Luís, Capital do Estado do Maranhão. In: MARQUES, Francisca. E. de S. Jornalismo cultural. Da memória ao conhecimento. São Luís: UFMA/Chamaré/NEEC, 2005, p. 113- 140.

MONUMENTOS HISTÓRICOS DO MARANHÃO. São Luís: Ministério do Interior/projeto Rondon/SIOGE, 1979.

MOREIRA. Arthur. Gomes de Castro, Benedicto Leite e Urbano Santos. Rio de Janeiro: jornal do Comercio Rodrigues \& CIA., 1939.

REYNAUD, Françoise. O Brasil de Marc Ferrez São Paulo: Instituto Moreira Salles, 2005.

OTÁVIO, Rodrigo. Depoimento de um dos heróis do cerco de Caxias sobre a Revolução dos Balaios. São Paulo, Siciliano, 2001.

NUNES, Benedito; HOTOUM, Milton. Crônicas de duas cidades: Belém e Manaus. Belém: SECULT, 2006.

PACHECO, Fellipe C. História eclesiástica do Maranhão. São Luís: Departamento de Cultura do Maranhão/Gráfica Lux, 1968.

PALHANO. Raimundo. A produção da coisa pública. Serviços públicos e cidadania na Primeira República: a república ludovicense. São Luís IPES/SIOGE, 1988.

PAXECO, fran. Geografia do Maranhão. São Luiz: Typogravura Texeira, 1922.

PRADO JR, Caio. Evolução política do Brasil. São Paulo: Brasiliense, 2006.

RAMOS, Albani; DUARTE S. Moreira. São Luís Alma e História. São Luís: Instituto Geia, 2007.

REIS, Flávio. Grupos políticos e estrutura oligárquica no Maranhão. São Luís: Unigraf, 2007.

REIS, José C. Escola dos Annales. São Paulo: Paz e Terra, 2004.

SARDINHA, Maria da Graça. Álbum do Maranhão 1908 - Gaudêncio Cunha. Rio de Janeiro, Spala, 1987.

SCHOEPF, Daniel. George Huebner 1862-1935, um fotógrafo em Manaus. Manaus e São Paulo: Metalivros, 2005.

SERRA, Astolfo. Guia Histórico e Sentimental de São Luís do Maranhão. Rio de janeiro: Civilização Brasileira, 1965.

SILVA, Celeste A. A.. Jornais Maranhenses: 1821-1979. São Luís: SIOGE, 1981. 
VIDAL, Diana. Técnica e sociedade no Brasil. São Paulo: Contexto, 1994.

VIEIRA, Padre. História do futuro. Belém: Secult/IOE/Prodepa, 1998.

VIVEIROS, Jerônimo de. História do Comércio do Maranhão 1896 - 1934. São Luís: Associação Comercial do Maranhão/LITHOGRAF, 1992.

VIVEIROS, Jerônimo de. Benedito Leite. Um verdadeiro republicano. Rio de Janeiro: Taveira, 1957.

VIVEIROS, Jerônimo de. História do Comércio do Maranhão 1612 - $1895.1^{\circ}$ Volume. São Luís: Associação Comercial do Maranhão/Oficinas Gráficas do Jornal do Brasil, 1954.

VI Recenseamento Geral do Brasil 1950/Estado do Maranhão. Volume XII, Tomo 1. Rio de Janeiro: Serviço Nacional de Recenseamento/Conselho Nacional de Estatística, 1950

WILliAM, Frederick G; MORAES Jomar. Poesias e prosas reunidas de Sousândrade. São Luís: AML/UFMA/Fundação Sousândrade, 2003.

ZENKNER, Tais. O modo de fazer cidades portuguesas: as Leis das Índias e a forma da cidade de São Luís. In: PONTUAL, V; CARNEIRO, A. R. S. História e Paisagem. Ensaio urbanístico do Recife e de São Luís. Recife: Bagaço, 2005, p. 307238 